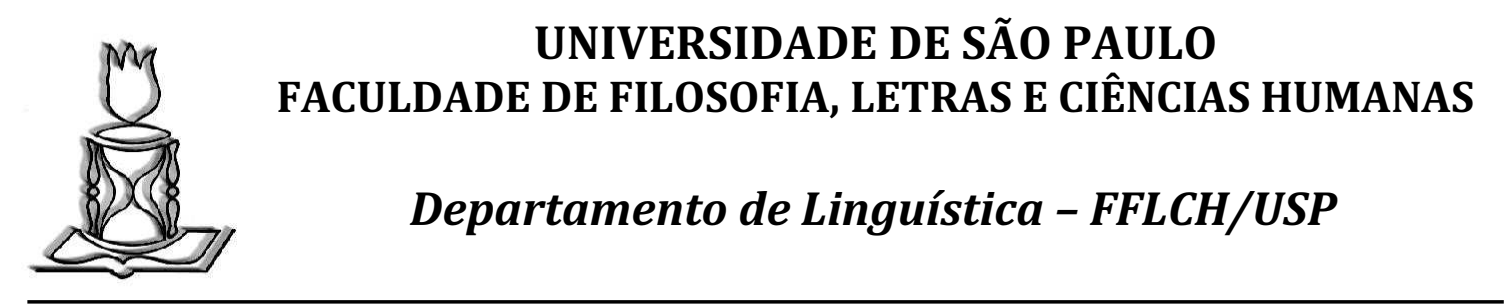

ELIANE SOARES DE LIMA

\title{
ENTRE COMPAIXÃO E PIEDADE: O ESTUDO DAS PAIXÕES EM SEMIÓTICA
}


ELIANE SOARES DE LIMA

li.soli@ig.com.br

\section{ENTRE COMPAIXÃO E PIEDADE: O ESTUDO DAS PAIXÕES EM SEMIÓTICA}

Tese apresentada ao Programa de Pós-Graduação em Semiótica e Linguística Geral do Departamento de Linguística da Faculdade de Filosofia, Letras e Ciências Humanas da Universidade de São Paulo, para obtenção do título de Doutor em Linguística.

Área de concentração: Semiótica e Linguística Geral

Orientador(a): Profa. Dra. Norma Discini 
Nome: LIMA, Eliane Soares de

Título: Entre compaixão e piedade: o estudo das paixões em semiótica

Tese apresentada ao Programa de Pós-Graduação em Semiótica e Linguística Geral do Departamento de Linguística da Faculdade de Filosofia, Letras e Ciências Humanas da Universidade de São Paulo, para obtenção do título de Doutor em Linguística

Área de concentração: Semiótica e Linguística Geral

Aprovada em: / 08 / 2014

\section{Banca Examinadora:}

Profa. Dra. Diana Luz Pessoa de Barros

Universidade de São Paulo (USP)

Prof. Dr. Luiz Tatit

Universidade de São Paulo (USP)

Profa. Dra. Elizabeth Harkot-de-La-Taille

Universidade de São Paulo (USP)

Profa. Dra. Maria de Lourdes Ortiz Gandini Baldan

Universidade Estadual Paulista "Júlio de Mesquita Filho" (UNESP)

Profa. Dra. Renata Ciamponi Mancini

Universidade Federal Fluminense (UFF) 
Ao meus pais, Manoel e Miriam. 


\section{Agradecimentos}

A Deus, meu grande Destinador, que ilumina as minhas ideias e supre as minhas forças para sempre seguir em frente.

Ao Ivã, por seu companheirismo, pela leitura atenta e cuidadosa do texto que sempre trazia preciosas contribuições, por toda a paciência e o apoio, por todo o esforço e a disposição, porque estava sempre pronto a me ouvir e me ajudar, e porque sem ele tudo teria sido muito mais difícil.

À professora Norma Discini, minha orientadora e amiga, porque mesmo longe soube se fazer perto, porque em meio a malas e tarefas mil encontrou tempo para ler e discutir o essencial deste trabalho, por ser aquela que me ensinou que é preciso acreditar em nossas ideias e defendê-las até o fim, e que o importante é colocar a alma em tudo aquilo que fazemos.

Ao professor Denis Bertrand, pelo generoso acolhimento durante o estágio de pesquisa desenvolvido na Université Paris 8.

À professora Diana Luz Pessoa de Barros, por ter se colocado à disposição para colaborar no que fosse preciso e por ter amavelmente aceitado presidir a banca examinadora.

Aos professores Jean Cristtus Portela e Elizabeth Harkot-de-La-Taille, pelos valiosos apontamentos feitos no Exame de Qualificação, que fizeram a tese ser o que agora se apresenta.

À professora Ude Baldan, por tudo; porque com ela tudo começou, porque com ela sempre pude contar, porque com ela aprendi a ser a pesquisadora que sou.

Aos professores Luiz Tatit e Renata Mancini, a quem muito respeito e admiro, por ter aceitado fazer parte da banca examinadora.

À professora Lucia Teixeira, por sua amizade e disposição carinhosa em ajudar. 
À Erica, secretária do Departamento, por todo o auxílio com a burocracia durante o tempo do Doutoramento.

Aos meus pais, pelo amparo incondicional, porque souberam compreender e não deixaram faltar apoio e paz para o desenvolvimento desta pesquisa.

À minha irmã Andreia, por ser o meu braço direito, sempre presente e pronta a ajudar, por torcer por mim e vibrar comigo a cada conquista.

À Juliana Tomé, pela amizade sincera e prestativa e pela ajuda com a revisão de parte desta tese.

À Juliana Attie, amiga de longa data, pelos inúmeros favores concedidos e por ser alguém com quem sempre posso contar.

À Carolina Tomasi, por tão gentilmente, em meio a suas leituras e escrita, ter aceitado traduzir os verbetes em italiano.

Aos familiares e aos amigos do coração que, de uma forma ou outra, souberam se fazer presentes durante toda essa jornada, pela força, incentivo e torcida, pelo apoio nos momentos de desânimo.

Aos amigos queridos que fiz em Paris, e em especial à Alessandra e ao Nilson, por terem sido peças-chave naquele momento, a família que me acolheu e com quem eu pude contar.

Aos amigos do Grupo de Estudos Semióticos da USP (GES - USP), pelo convívio, amizade e incentivo, pelas produtivas discussões sobre a teoria.

À Fundação de Amparo à Pesquisa do Estado de São Paulo (FAPESP), pelas bolsas concedidas, que me permitiram tanto a dedicação exclusiva a esta pesquisa, quanto o estágio realizado no Exterior durante um ano.

Meu muito obrigada a todos! 
Pour dire franchement les choses, nous récusons le privilège implicite accordé à l'intelligible; la place accordée au sensible ne doit pas être concessive; après avoir exploré les voies de l'intelligible, il faudrait par scrupule aussi envisager le sensible. Notre position consiste à admettre qu'il y a d'abord ou déjà le sensible.

Claude Zilberberg 


\section{RESUMO}

LIMA, Eliane Soares de. Entre compaixão e piedade: o estudo das paixões em semiótica. $224 \mathrm{f}$. Tese de Doutorado - Faculdade de Filosofia, Letras e Ciências Humanas, Universidade de São Paulo (USP), 2014.

Quando o interesse pelos afetos surgiu na semiótica greimasiana, a problemática da enunciação, do discurso em ato, ainda não era trazida à luz de modo significativo. Propôs-se um estudo no domínio do discurso debreado, com a investigação - ainda que constatando as indicações e características de um outro universo de significação, o sensível - orientada predominantemente pela gramática da ação, amplamente desenvolvida no quadro teórico-metodológico da disciplina. As paixões passaram a ser vistas, desde então, na perspectiva da teoria, como um arranjo de modalidades, como efeitos de sentido de qualificações modais que alteram o sujeito de estado. A articulação modal permite, sem dúvida, definir a maneira de ser que "sensibiliza" o esquema narrativo e o rege, identificando os estados dos sujeitos narrativos. Ela está, de fato, na base da configuração patêmica, uma vez que os arranjos modais definem mesmo o ser do sujeito e o conflito que caracteriza seus "estados de alma", tornando possível a depreensão das fases da manifestação afetiva enunciada e o seu papel na produção de uma dada paixão. Por outro lado, as modalidades por si mesmas não explicam o "excesso" propriamente dito, a intensidade das modulações que subjazem à estrutura modal e a patemizam. Nesse sentido, a pesquisa aqui apresentada se concentra na tentativa de contribuir para a expansão e reformulação do modelo semiótico de análise das paixões, mostrando a legitimidade e os rendimentos da incorporação das circunstâncias perceptivas, de articulação entre o sensível e o inteligível, como dispositivos constituintes e determinantes da configuração de uma dada interação patêmica. Retomando a discussão apresentada nas páginas introdutórias de Semiótica das paixões (GREIMAS; FONTANILLE, 1993) e aquela presente em alguns dos verbetes de Tensão e significação (FONTANILLE; ZILBERBERG, 2001), defenderemos - a partir da análise de paixões semelhantes, como é o caso da compaixão e da piedade - que, além do exame das modalidades estruturantes do núcleo passional, é preciso atentar também, senão sobretudo, às precondições desta articulação modal, concebida, a paixão, como resultado de correlações sensíveis e inteligíveis. Consideraremos, pois, o estado juntivo que caracteriza sujeito e objeto, a existência semiótica, como uma relação de percepção, na qual prevalece a problemática das modulações e do discurso em ato. Importa a nossa investigação compreender o processo de configuração da interação passional na própria manifestação do acontecimento da semiose, para o que postulamos uma análise dos afetos que não se prenda unicamente à passionalidade do sujeito enunciado, ou ao discurso apaixonado do sujeito enunciante, mas sim à própria emergência passional da relação intersubjetiva, às condições enunciativas de sua produção.

PALAVRAS-CHAVE: afeto; interação; percepção; valor; compaixão; piedade. 


\section{ABSTRACT}

LIMA, Eliane Soares de. Between compassion and pity: the study of passions in semiotics. 224 p. Doctoral Dissertation - Faculty of Philosophy, Letters and the Human Sciences, University of São Paulo (USP), 2014.

By the time the interest in affections arose in Paris School (Greimassian) semiotics, the issue of enunciation, of the discourse in act had not been significantly raised yet. A proposal for a study in the field of the enunciated discourse was then put forward. Even though signs and characteristics of another universe of signification - the sensitive one - were perceived, the analysis of the enunciated discourse remained primarily oriented by the grammar of action, widely developed in the theoretical-methodological scope of this field of study. Since then passions have been seen from the theoretical perspective as an arrangement of modalities, as signification effects of modal qualifications which alter the subject's state. Modal articulation definitely helps to define the subject's way of being, which not only makes the narrative scheme more sensitive but also rules it, identifying the subject 's states in the narrative. In fact, the modal articulation provides the basis for the pathos configuration, as modal arrangements define both the subject's being and the conflict which characterizes the subject's state of feelings, making it possible to notice the manifestation phases of the enunciated affections and their role in the creation of a given passion. On the other hand, modalities by themselves do not explain excess - the intensity of the modulations underlying the modal structure and making it more sensitive. Therefore, this research aims to contribute to expand and restructure the semiotic model of passion analysis, showing the legitimacy and the improvements resulting from the incorporation of perceptive circumstances, the articulation between sensitive aspects and intelligible ones used as constituent and defining devices to outline a given integration of affections. Retrieving the discussion presented in the introductory pages of The Semiotics of passions (Greimas; Fontanille, 1992) as well as in some chapters of Tension and signification (Fontanille; Zilberberg, 1998), we intend to defend the idea, based on the analysis of similar passions such as compassion and pity, that it is not only important to examine the structural modalities in the passionate nucleus but it is also mostly important to focus on the preconditions of such modal articulation conceiving a passion as a result of sensitive and intelligible correlations. We will therefore consider the junction state, which characterizes subject and object, the semiotic existence, as a relation of perception in which the issue of modulations and discourse in act is dominant. It is also relevant for this study to understand the configuration process of the emotional interaction in the actual manifestation of the semiosis event, for which we propose an analysis of affections. As well as dealing with the enunciated subject's passions and the enunciator's passionate discourse, this analysis aims to highlight the passionate emergency of the intersubjective relation and the enunciating conditions of its creation process.

KEYWORDS: affection; interaction; perception; value; compassion; pity. 


\section{RÉSUMÉ}

LIMA, Eliane Soares de. Entre compassion et pitié: l'étude des passions en sémiotique. 224 p. Thèse de Doctorat. Faculté de Philosophie, Lettres et Sciences Humaines, Université de São Paulo (USP), 2014.

Lorsque les sémioticiens se sont mis à accorder dans leur propos quelque intérêt à l'affectif, la problématique de l'énonciation, du discours en acte, n'avait pas encore trouvé beaucoup de place dans leurs préoccupations. On s'est pour l'essentiel contenté d'étudier alors le discours débrayé; tout en admettant les caractéristiques d'un nouveau pan de l'engendrement de la signification, à savoir celui du sensible, l'investigation restait tournée avant tout vers la grammaire de l'action, déjà largement consolidée dans le cadre théorique et méthodologique de la sémiotique. Dans cette théorie, les passions se lisaient comme des agencements de modalités, comme des effets de sens des qualifications modales portées par le sujet d'état. Certes l'articulation modale permet de définir la manière d'être qui "sensibilise » le schéma narratif et qui régit les états des sujets narratifs; elle forme le socle de la configuration pathémique, puisque les agencements modaux dessinent l'être du sujet et les conflits de ses "états d'âme ", ce qui permet de saisir les différentes phases de la manifestation affective énoncée ainsi que leur rôle dans l'engendrement de telle ou telle passion. Néanmoins les modalités ne sauraient à elles seules expliquer ce qui est le propre du «trop » en tant que tel, autrement dit l'intensité des modulations sous-jacentes à la structure modale et qui en font quelque chose de l'ordre du pathémique. Voilà pourquoi notre recherche s'applique à contribuer à l'expansion et à la reformulation du modèle sémiotique d'analyse des passions, en cherchant à montrer la légitimité et le rendement de l'intégration des circonstances perceptives, de l'articulation du sensible et de l'intelligible en tant que dispositifs déterminants dans la configuration des interactions pathémiques. En reprenant les développements des pages introductives de Sémiotique des passions (GREIMAS ; FONTANILLE, 1991) et de plusieurs chapitres de Tension et signification (FONTANILLE; ZILBERBERG, 1998), nous soutenons, au sujet de passions apparentées comme la pitié et la compassion, que leur compréhension nécessite, outre l'examen des modalités structurant leur noyau passionnel, un regard porté sur les pré-conditions d'une telle articulation modale, la passion étant dès lors envisagée à la croisée de ses déterminations sensibles et intelligibles. L'existence sémiotique, l'état jonctif réunissant sujet et objet, nous l'étudions comme une relation perceptive où il s'agit d'élucider la problématique des modulations tensives et du discours en acte. Cherchant à cerner la configuration de l'interaction passionnelle dans l'événement même de la sémiosis, nous préconisons une analyse des affects qui prenne en compte, en plus de la passionnalité des sujets énoncés ou de celle du sujet énonçant, l'émergence même du rapport intersubjectif, les conditions énonciatives de sa production.

MOTS-CLÉS: affect ; interaction ; perception ; valeur; compassion; pitié. 


\section{SUMÁRIO}

\section{INTRODUÇ̃̃o}

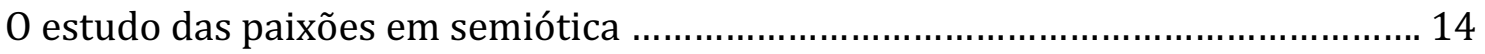

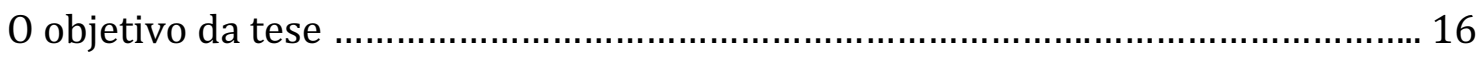

Estruturação do trabalho desenvolvido ............................................................. 17

Capítulo 1 - Semiótica das PaiXões: discussão SOBRE tóPICOS teóRICOS E METODOLÓGICOS

1.1 Dos estados de coisas aos estados de alma: o nascimento de uma semiótica das

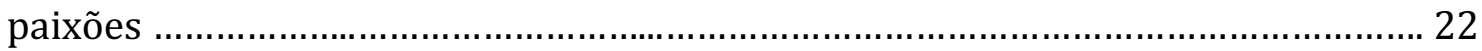

1.1.1 Das condições às pré-condições de configuração da interação passional ...... 32

1.2 Entre o sensível e o inteligível: os diferentes modos de interação ...................... 37

1.2.1 Sobre a noção de percepção em semiótica ....................................................... 40

1.2.2 Do valor ao afeto: o modo de convocação e a produção do "valor do valor"... 45

1.2.3 Modos primários e modos complexos de interação afetiva ................................ 52

1.2.3.1 Os modos complexos de interação afetiva: condições de configuração dos

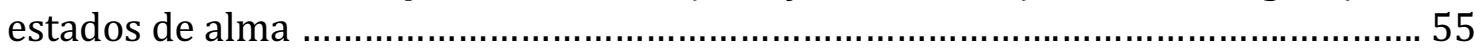

1.2.3.2 Percurso da análise: uma interpretação tensiva do esquema passional

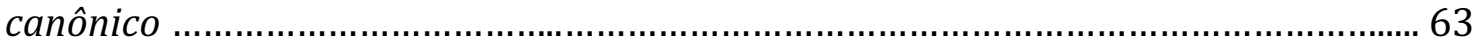

1.3 Do enunciado à enunciação: a dimensão passional dos textos .......................... 74

\section{CAPÍTULO 2 - ENTRE COMPAIXÃo E PIEDADE: DA JUNÇão À PRESENÇA}

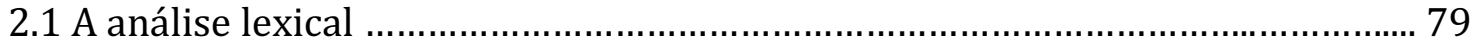

2.2 Compaixão e piedade: levantamento das definições …………………………... 81

2.3 A tradução sintáxica da significação: a estrutura subjacente à definição ......... 93

2.3.1 Das modalidades às modulações: os parâmetros tensivos ............................ 101

2.4 Considerações gerais sobre a análise lexical ..................................................... 108

Capítulo 3 - Entre enunciação E enunciado: a ConfiguraÇão do EFeito PASSIONAL EM ATO

3.1 Notas preliminares sobre a análise do corpus

3.1.1 Sintaxe discursiva e textual: o gerenciamento da percepção e da interação patêmica pelos procedimentos de discursivização e textualização. 
3.2 "Conversa de bois" e "Campo geral", de Guimarães Rosa: a configuração de diferentes modos de interação afetiva ..................................................................... 123

3.2.1 Considerações sobre o resultado da análise ................................................. 142

3.3 "Negrinha", de Monteiro Lobato: horror, piedade e compaixão ....................... 144

3.3.1 Considerações sobre o resultado da análise ................................................ 156

3.4 “Baleia”, de Graciliano Ramos: entre compaixão e piedade .............................. 159

3.4.1 Considerações sobre o resultado da análise ................................................. 166

3.5 Conclusão geral sobre as análises: avaliação das hipóteses teórico-

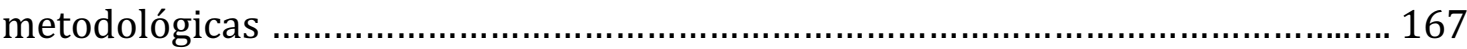

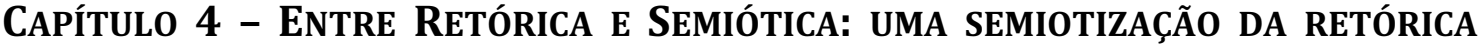 DAS PAIXÕES}

4.1 Retórica e Semiótica: pontos de convergência 173

4.2 A articulação do sensível com o inteligível no momento da sanção: quando o fazer-crer é também um fazer-sentir 177

4.30 gerenciamento do pathos no discurso do enunciador-orador 184

4.4 Retórica, Poética e Semiótica: o interesse pela produção dos efeitos de sentido 194

\section{CONCLUSÃo}

Recapituação, avaliação e desdobramentos 202

REFERÊNCIAS BIBLIOGRÁFICAS 209
ANEXOS
Anexo 1 (Resumo parafrástico do trecho de "Conversa de bois") 218
Anexo 2 (Resumo parafrástico do trecho de "Campo geral") .................................. 220
Anexo 3 (Resumo parafrástico do conto "Negrinha") ........................................... 222
Anexo 4 (Resumo parafrástico do conto "Baleia") ................................................. 224 
INTRODUÇÃo 
D'un côté, on peut décrire les dispositions - c'est ce que nous cherchons -, les dispositions de telle passion particulière, dans sa relation avec d'autres, etc.; et de l'autre, il y a

l'ambition plus grande que nous avons : celle d'envisager une dimension passionnelle du discours.

A. J. Greimas

\section{0 estudo das paixões em Semiótica}

O estudo das paixões, longe de se constituir como um domínio de pesquisa da atualidade, é, de longa data, campo de considerável importância e trabalho de reflexão. São séculos e séculos de interesse, muitos pontos de vista e formas de abordagem, e ainda assim sua natureza e qualidades intrínsecas, suas condições de emergência, continuam a desafiar os estudiosos do assunto, sempre reacendendo a discussão: afinal, de onde vêm, o que são as paixões? Que papel elas desempenham no "funcionamento" do ser humano e/ou no meio sócio-cultural? Qual a sua função nos discursos, tanto no que diz respeito à produção quanto à recepção?

Com perguntas bem mais modestas do que essas, a semiótica de linha francesa se rende ao estudo das paixões ao constatar, pouco a pouco, a sua relevante atuação no processo de geração da significação discursiva. Entendeu-se que a inclusão dessa problemática no quadro geral da teoria, ao ajudar na compreensão de questões antes deixadas à sombra, aumentava a legibilidade dos processos semióticos subjacentes aos enunciados. De toda maneira, tal inserção se fez de forma moderada, e mesmo controlada, para que não se perdessem de vista os princípios epistemológicos defendidos, assentados na perspectiva imanentista, para a qual o texto é objeto autônomo, isto é, uma totalidade significante cujo sentido procede da dinâmica interna de relações entre suas unidades constituintes.

Atenta, pois, à necessidade de evitar uma tomada de posição ontológica, a semiótica das paixões procurou afastar qualquer possibilidade de análise que a fizessem retroceder a uma discussão de natureza metafísica, e buscou, ao contrário, estabelecer conceitos operatórios passíveis de ser usados no exame dos afetos lexicalizados, considerados modelos de previsibilidade, sistema conotativo 
de reconhecimento de interações passionais já moldadas pelo uso. A ideia não era propor tipologias de cunho taxionômico - tal como, em diferentes ocasiões, haviam feito os filósofos -, relativizadas pelos contextos culturais dentro dos quais elas se elaboram, mas oferecer caminhos para um estudo propriamente discursivo das paixões, de seu percurso sintagmático de configuração. Os estados de alma foram, dessa forma, concebidos no ponto de vista da semiótica como estrutura actancial intersubjetiva articulada por combinações modais. Para se resguardar de qualquer proximidade com abordagens de tipo psicologizante, os semioticistas privilegiaram uma descrição sintáxica dos núcleos passionais discursivizados, com ênfase em seus dispositivos discretos, inteligíveis, sem muito explorar as peculiaridades próprias ao sentir que os gera e dinamiza - traduzido em termos de timia (euforia / disforia), categoria central nas condições de emergência das paixões.

A dimensão propriamente sensível ${ }^{1}$ dos afetos, todavia, na medida em que os estudos em semiótica foram ultrapassando as fronteiras do discurso debreado para se interessar também por suas condições de produção, pela práxis enunciativa, não demorou a mostrar a sua relevência; e, a par da análise em termos de modalidades, passou a se impor do mesmo modo a investigação das modulações tensivas que lhes subjazem e definem o seu modo de existência. Para além da depreensão e explicitação dos processos significantes já configurados, as condições de sua emergência, o seu devir, bem como o impacto dos efeitos de sentido decorrentes, começaram a despertar maior interesse, e os desenvolvimentos da teoria passaram a se empenhar na busca por modelos de análise próprios não só ao exame das unidades inteligíveis envolvidas no percurso de geração da significação, mas também, se não sobretudo, das especificidades de natureza sensível que a elas se articulam.

10 termo "sensível" está sendo entendido aqui em seu sentido mais amplo, tímico-fórico, que conjuga, no ato perceptivo, a sensorialidade à afetividade - tal como o explora a semiótica de linha francesa. 


\section{Objetivos da tese}

Concebendo, a partir dessa perspectiva, as paixões como respostas a determinado modo de interação afetiva, diferentemente caracterizados conforme varie a articulação do sensível com o inteligível no processo intersubjetivo, regulado, por sua vez, pela percepção, pelo contato, antes de mais nada, perceptivo entre os actantes, propomos neste trabalho uma atualização do modelo de análise da semiótica das paixões, no qual não só as combinações modais sejam contempladas, mas também as modulações fóricas, próprias ao sentir passional que as configura e as determina como estrutura patêmica.

A ideia é sugerir um percurso de investigação a partir do qual noções como presença, campo de presença, percepção, sensível / inteligível - todas, embora já semiotizadas, emprestadas da fenomenologia - comprovem o seu potencial operatório e, por conseguinte, a viabilidade de uma abordagem sintáxica dessa problemática, sem ferir, por isso mesmo, a epistemologia que define e diferencia a semiótica discursiva. Em defesa, então, da intrínseca relação entre sensível e inteligível nos processos de geração da significação, interessa-nos demonstrar a possibilidade do exame das circunstâncias nas quais, durante a interação perceptiva, uma dessas dimensões se sobrepõe à outra e dá origem a modos de interação afetiva mais sensíveis ou mais inteligíveis; isto é, a fenômenos patêmicos com maior mobilização da sensibilidade do sujeito da percepção e menor de inteligibilidade, ou vice-versa, quando há menor convocação sensível e maior processamento inteligível da presença do Outro, do objeto-valor percebido. Importa, nesse sentido, oferecer meios para a compreensão do que, na perspectiva da tensividade, do discurso em ato, determina a densidade de presença do sensível e do inteligível - o seu grau de atuação - no momento de emergência da intersubjetividade, da afetividade na relação interactancial.

0 objetivo é o de que esse estudo, filiado às proposições teóricometodológicas da semiótica tensiva, comprove o papel fundamental das modulações fóricas na produção dos estados de alma, bem como as condições para um exame sistemático dessa participação, chamando a atenção para a necessidade 
de incluí-las no modelo de análise sugerido pela teoria. Ademais, acreditamos que essa perspectiva torna possível o estabelecimento de uma tipologia dos afetos com base em suas particularidades sintáxicas, mais gerais e abstratas, anterior, dessa forma, a sua lexicalização e axiologização, às especificidades da interpretação sócio-cultural; uma classificação da qual mesmo as paixões sem nome, os fenômenos passionais ainda não fixados pelo uso, poderiam fazer parte, por estar ela fundamentada no modo de interação afetiva desencadeado: mais sensível ou mais inteligível, mais da ordem de uma conjunção ou de uma disjunção.

Ao unir as especificidades do sentir à descrição das modalidades que traduzem a interação patêmica em causa, as modulações tensivas ajudam, como procuraremos demonstrar, a compreender e a explicar, de um ponto de vista semiótico, as diferenças qualitativas de paixões semelhantes, como é o caso, por exemplo, da compaixão e da piedade, que examinaremos em pormenor para verificar nossa hipótese de que a primeira é mais sensível, procedente de um "sentir com", e a segunda, mais inteligível, típica a um "sentir por". Também a eficácia persuasiva dos afetos, a sua força de impacto sobre os sujeitos, passa, nesse ponto de vista analítico, a poder ser avaliada, assinalando, segundo cremos, tanto o papel de destaque da dimensão sensível nos processos significantes, no percurso de geração da significação, quanto a possibilidade de um exame semiótico dessa atuação.

\section{Estruturação do trabalho desenvolvido}

Dividimos o conteúdo da pesquisa aqui apresentada em quatro capítulos, ao longo dos quais procuramos não apenas discutir teoricamente as questões levantadas, mas oferecer caminhos de análise, modelos passíveis, esperamos, de ser utilizados para o exame da configuração de paixões outras, para além dos limites dos apontamentos feitos em relação à compaixão e à piedade.

No primeiro capítulo - Semiótica das paixões: reflexão sobre tópicos teóricos e metodológicos -, buscamos conjugar a explanação detalhada do caminho trilhado 
pela disciplina para chegar à elaboração de uma semiótica das paixões a nossas inquietações e sugestões a propósito da necessidade de continuidade desse percurso já desenvolvido, incluindo agora a problemática do sensível na sua articulação ao inteligível. Não pensamos em momento algum em uma substituição dos modelos, deixando-se de lado a análise das modalidades para se privilegiar a das modulações tensivo-fóricas, mas sim em uma relação de complementaridade, com a perspectiva do discurso em ato, das condições enunciativas de emergência dos núcleos passionais aliada àquela do discurso manifestado, das paixões enunciadas. Trata-se, portanto, de um capítulo voltado à proposição de continuidade, de retomada e atualização da discussão própria à vertente denominada semiótica das paixões. Apoiamo-nos, para isso, sobretudo nos trabalhos de Jacques Fontanille e Claude Zilberberg acerca da noção de tensividade.

No segundo capítulo - Entre compaixão e piedade: da junção à presença -, dedicamo-nos a atrelar as sugestões teórico-metodológicas mais gerais do capítulo anterior a um corpus específico, à análise de dois estados de alma já firmados pelo uso, compaixão e piedade. Assim, mesmo cientes do relativismo cultural das acepções dicionarizadas, optamos, de início, por uma investigação de base lexical exatamente para ter parâmetros mais concretos de avaliação das proposições de ordem mais abrangente e abstrata. Com esse intuito, procuramos, a partir dos segmentos definicionais de cada um desses núcleos patêmicos, identificar, tanto na sua composição estrutural mais superficial (configurada em termos de modalidades) quanto na dinâmica mais profunda (na qual atuam as modulações), responsável pelas circunstâncias de emergência da interação afetiva que elas descrevem, as semelhanças e diferenças entre um afeto e outro, chamando a atenção para a estreita, e importante, relação entre esses dois níveis de configuração dos estados de alma.

No terceiro capítulo - Entre enunciação e enunciado: a configuração do efeito passional em ato -, após a depreensão, no capítulo antecedente, da estrutura sintáxica elementar à compaixão e a piedade, detemo-nos em análises da ordem do discurso em ato propriamente dito, para verificar, através do exame das estratégias enunciativas adotadas pelo enunciador de cada um dos textos selecionados para 
compor o corpus da pesquisa, a relação que as invariantes figurais dos afetos em questão entretêm com as variáveis figurativas manifestadas, condicionando os afetos provocados no sujeito da percepção - no nosso caso, o enunciatário-leitor -, aos efeitos de sentido sensíveis produzidos pela predicação tensiva dos enunciados, concebidos, por sua vez, como campo de presença no qual se dá, se configura, o modo de interação afetiva compassivo e/ou piedoso. Para isso, quatro narrativas literárias, de diferentes autores, foram examinadas: "Conversa de bois" e "Campo geral" ${ }^{2}$, de Guimarães Rosa; "Negrinha", de Monteiro Lobato; e "Baleia", de Graciliano Ramos. Interessa, nessa segunda etapa de análise das condições de emergência dos estados de alma de compaixão e piedade, comparar os procedimentos de discursivização e textualização dos enunciados analisados para compreender o modo de configuração da tensão que, no momento da leitura, determina a convocação e a articulação do sensível e do inteligível, bem como a consequente produção de certo modo de interação afetiva entre o enunciatárioleitor, sujeito da percepção, e os atores do enunciado, objeto-valor percebido.

No quarto capítulo - Entre Retórica e Semiótica: uma semiotização da retórica das paixões -, para finalizar a discussão sobre a atualização da semiótica das paixões na perspectiva do discurso em ato, na qual a atividade enunciativa (produção / recepção dos enunciados) e a tensividade ocupam papel de destaque, propomos estabelecer um diálogo entre retórica e semiótica para enfatizar, de um lado, a função do enunciatário, o pathos do discurso, no processo de geração da significação, do outro, a possibilidade de uma análise semiótica dessa participação. Queremos com isso chamar a atenção para a maneira como se inter-relacionam as instâncias do enunciador, do enunciado e do enunciatário na produção e recepção dos efeitos passionais, quando se alia ao fazer-crer um fazer-sentir que o antecede e determina, condicionando à manifestação do enunciado o gerenciamento discursivo do modo de envolvimento afetivo do enunciatário, o seu modo de adesão ao conteúdo transmitido. Trata-se de demonstrar que os apontamentos de ordem

2 A narrativa "Campo geral", de Guimarães Rosa, já foi estudada por nós em outras ocasiões e em especial na Dissertação de Mestrado (2010). Optamos por retomá-la aqui em função de sua proximidade temático-figurativa com o conto "Conversa de bois", do mesmo autor, dando-nos a oportunidade de uma análise comparativa que ilumina o propósito buscado neste novo contexto de pesquisa. 
ético-cultural sobre as paixões, feitos pela retórica antiga, são passíveis de interpretações sintáxicas a partir das quais se explicitam as especificidades da configuração propriamente discursiva em cada caso.

Esperamos, assim, que o trabalho aqui apresentado possa trazer elementos para a retomada da discussão em torno da semiótica das paixões. Embora muito se fale de afetividade, do sensível, da percepção e do corpo no quadro atual da semiótica discursiva, no que diz respeito ao estudo das paixões especificamente, a exploração teórica e metodológica proposta pela teoria continua a deixar de fora essas questões. A intenção, de um modo geral, é, então, apresentar sugestões e possibilidades de desenvolvimento e atualização desse domínio, como também de abertura do seu campo de atuação. 
Capítulo 1

Semiótica das paixões: reflexão sobre tópicos teóricos e metodológicos 
[...] a investigação deve partir antes de tudo dos fatos. Se nos perguntamos o que é um fato, vemos que ele se define como algo que se deve encontrar no curso de uma pesquisa, e que se apresenta sempre como um enriquecimento inesperado e uma novidade em relação aos fatos anteriores. Portanto, não se deve esperar dos fatos que eles se organizem por si mesmos numa totalidade sintética que forneceria por si mesma sua significação.

J. -P. Sartre

\subsection{Dos estados de coisas aos estados de alma: o nascimento de uma Semiótica das paixões}

Tendo surgido em meio às discussões de cunho estruturalista da década de 60, a semiótica francesa, interessada nos modos de produção da significação dos textos, procurou firmar-se enquanto uma teoria geral das ciências da linguagem, com metodologia eficaz e coerente. Assim, iniciou seus estudos rejeitando tudo aquilo que de perto ou de longe parecesse estar ligado a subjetivismos, e concentrou toda a sua atenção na depreensão das operações lógicas que estruturam os discursos. Como explica Fontanille (2002a, p. 6013), "falar de sentimentos, afetos, paixões e estados de alma, no campo das ciências da linguagem, nas décadas de 1950 e 60, era cometer mais que um erro, era um mau gosto, quando não um grave disparate científico".

Com base em proposições linguísticas, antropológicas e mesmo filosóficas, os esforços iniciais da disciplina dirigiram-se, então, à concepção lógica de estruturação dos discursos, o que resultaria na elaboração do percurso gerativo do sentido, no qual as transformações narrativas, a dimensão do fazer dos enunciados, ocupou papel de destaque. Os seres do enunciado, as personagens, foram despidos de todo e qualquer revestimento figurativo e interessavam somente como função narrativa dentro da estrutura fixada pelos predicados de ação, tal como propunha Vladimir Propp nos estudos apresentados em Morfologia do conto maravilhoso

\footnotetext{
${ }^{3}$ Salvo menção em contrário, todas as traduções feitas nesta tese são de nossa responsabilidade, e estarão acompanhadas, em nota de rodapé, do trecho original.

Trecho original: "Parler de sentiments, d'affects, de passions et d'états d'âme, dans le champ des sciences du langage, au cours des années 50 et 60 , c'était commettre plus qu'une erreur, mais une faute de goût, sinon un grave impair scientifique."
} 
(1984). Como explicam Fontanille e Tore (2006, p. 24 ${ }^{4}$ ), "nessa primeira fase, a semiótica é ainda basicamente uma semântica estrutural que se ocupa sobretudo de narrativas simples nas quais a dimensão da busca de objetos de valor é central e linear".

Os estudos subsequentes, com a intenção de aperfeiçoamento do modelo actancial criado, trouxeram à cena a teoria das modalidades, que rapidamente começou a ganhar espaço e maior interesse entre os semioticistas. Tratava-se de um refinamento da análise dos textos, no qual os estados, antes vistos apenas como marcos das transformações - estado inicial e estado final -, monstravam os primeiros sinais de sua importância enquanto núcleos de significação paralelamente à ação. Todo um arcabouço teórico e metodológico foi, a partir daí, desenvolvendo-se, e chegou a instaurar uma gramática semionarrativa.

Em seu texto de 1976, "Pour une théorie des modalités"5, Greimas, postulando a existência de duas funções-predicado, o fazer (próprio à transformação) e o ser (próprio aos estados juntivos), ambos denominados enunciados elementares, apresenta o que ele chamou de uma definição sintáxica do sujeito narrativo a partir da sua relação com um objeto-valor qualquer. É o momento dos primeiros estudos em relação à representação sintagmática do percurso narrativo do sujeito que caracterizará o esquema narrativo canônico, no qual estão previstas as etapas da manipulação, da competência, da performance e da sanção, todas consideradas como estruturas modais.

Embora, nesse texto, o foco de interesse continue a recair sobre a dimensão do fazer, os enunciados de estado já aparecem como merecedores de maior desenvolvimento dentro das proposições da teoria. Conforme assinala Greimas na Introdução de Du sens II (1983, p. $9^{6}$ ), “do ponto de vista sintáxico, [...] uma tal circulação de objetos, para que pudesse dar lugar a uma interpretação geral e dedutiva da narratividade, exigia um reexame das relações entre os objetos e os

\footnotetext{
${ }^{4}$ Trecho original: "Dans cette première phase, la sémiotique est encore franchement une sémantique structurale, qui s'occupe essentiellement de récits simples où la dimension de la quête des objets de valeur est centrale et linéaire."

${ }^{5}$ Revue Langages, no 43. 0 texto foi replublicado anos depois em Du sens II (GREIMAS, 1983).

${ }^{6}$ Trecho original: "Du point de vue syntaxique, cependant, une telle circulation d'objets, pour qu'elle puisse donner lieu à une interprétation générale et déductive de la narrativité, demandait un réexamen des relations entre les objets et les sujets". (GREIMAS, 1983, p. 9)
} 
sujeitos". A (re)integração dos afetos, das paixões, no quadro geral da semiótica francesa, com a atenção dos semioticistas caminhando cada vez mais em direção ao sujeito dos enunciados, foi, dessa forma, apenas uma questão de tempo.

Para Fontanille e Tore (2006, p. $25^{7}$ ), “o estudo do 'ser do fazer' permite a Greimas uma abordagem plenamente semiótica da subjetividade, considerada antes de tudo como lugar da instalação, da variabilidade e finalmente do julgamento de uma 'competência'". Mas é bem verdade que o interesse da semiótica pelos afetos não se deve apenas à coerência interna seguida pela teoria, pois, como lembra Fontanille (1993a, p. $157^{8}$ ), “a questão das paixões estava em voga na

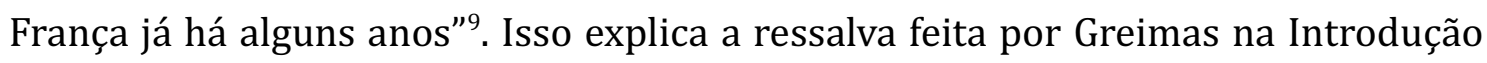
de Du sens II (1983, p. $\left.15^{10}\right)$, quando ele assinala:

A semiótica por muito tempo proibiu-se de lidar com tudo aquilo que de longe ou de perto procedesse do domínio da psicologia. Essa postura, plenamente justificada em seus inícios, quando era preciso conceber os actantes definidos como simples "agentes", livres do fardo secular de determinações psicologizantes acumulado em torno dos "caracteres" e dos "temperamentos", não se impõe mais atualmente: ao contrário, a falta de instrumentos de análise, quando se trata de abordar os sentimentos e as paixões "de papel" encontradas nos discursos, já aparece como uma limitação metodológica arbitrária.

O estudo das paixões no domínio da semiótica francesa tem seu início em 1978, com a publicação do Bulletin 6, intitulado "Pour une théorie des passions", que anunciava as primeiras hipóteses de trabalho. Dois anos do Seminário de Semiótica geral de Paris (1978-1979 e 1979-1980) foram dedicados a pesquisas exploratórias e à busca de um método de descrição geral e abstrato, isento de

\footnotetext{
7 Trecho original: "L'étude de l'être du faire' permet à Greimas une approche franchement sémiotique de la subjectivité, considérée avant tout comme lieu de l'installation, de la variabilité et finalement du jugement d'une 'compétence' ".

${ }^{8}$ Trecho original: “[...] la question des passion était agitée en France depuis une dizaines d'années $[\ldots]^{\prime \prime}$

${ }^{9}$ Para maiores detalhes sobre o assunto, consultar a artigo de Fontanille, "Sémiotique des passions", no livro Questions de Sémiotiques (2002), dirigido por Anne Hénault.

${ }^{10}$ Trecho original: "La sémiotique s'est longtemps interdit de toucher à tout ce qui relève, de près ou de loin, du domaine de la psychologie. Ce parti pris, pleinement justifié à ses débuts, alors qu'il fallait poser d'abord les actants définis comme de simples "agissants", nettoyés de la gangue séculaire de déterminations psychologisantes accumulée autour des "caractères" et "tempéraments", ne s'impose plus aujourd'hui: au contraire, l'absence d'instruments d'analyse, lorsqu'il s'agit d'aborder des sentiments et des passions "de papier" rencontrés dans les discours, apparaît déjà comme une limitation méthodologique arbitraire.” (GREIMAS, 1983, p. 15)
} 
considerações ideológicas e psicologizantes. Depois do exame sistemático das teorias propostas pelos filósofos, para o estudo das paixões, constatando que em meio a algumas diferenças todas elas tinham como traço comum a classificação de base taxionômica, a semiótica procurou trabalhar na direção de uma descrição sintáxica das paixões-lexemas, por meio das modalidades. Interessava aos semioticistas depreender e descrever a organização interna dos afetos, o seu modo de estruturação, e, para isso, os então recentes desenvolvimentos da teoria das modalidades pareciam bastante pertinentes.

Um dos textos mais representativos dessa época, que introduz a noção de timia relacionando-a à perspectiva modal, é "De la modalisation de l'être", publicado pela primeira vez em 1979 no Bulletin 7, e republicado anos mais tarde em Du sens II (1983). Nesse artigo, Greimas trabalha suas primeiras ideias para a depreensão de uma sintaxe modal própria ao ser do sujeito narrativo e à série de sub-articulações significantes da massa tímica amorfa, indício do primeiro contato interactancial, caracterizado primitivamente por atrações e/ou repulsões. Conforme explica Fontanille (2002a, p. 603 ${ }^{11}$ ):

Depois de ter consagrado os anos precedentes à modalização do "fazer", para estabelecer a competência modal do sujeito narrativo, Greimas aborda o que ele chama a existência modal do sujeito. A categoria das "modalidades do ser" (dever-ser, querer-ser, poderser, etc.) é definida em relação a uma categoria mais profunda, a "foria" (literalmente: o que leva em direção a...). [...] É assim que os dois pólos da foria, a euforia e a disforia, serão convertidos respectivamente, e mais precisamente, em "desejável/indesejável" (/querer-ser/), em "indispensável/ nocivo" (/dever-ser/), em "possível/impossível" (/poder-ser/), etc...

0 objetivo era estabelecer um equilíbrio entre o desenvolvimento dos estudos relativos à modalização do fazer e os da modalização do ser, dos modos de existência semiótica do sujeito a partir de sua relação com o objeto-valor. Isso

\footnotetext{
${ }^{11}$ Trecho original: "Après avoir consacré les années qui précèdent à la modalisation du 'faire', pour établir la compétence modale du sujet narratif, Greimas aborde ce qu'il appelle alors l'existence modale du sujet. La catégorie des 'modalités de l'être' (devoir-être, vouloir-être, pouvoir-être, etc.) est défine par rapport à une catégorie plus profonde, la 'phorie' (littéralement: ce qui porte vers...). [...] C'est ainsi que les deux pôles de la phorie, l'euphorie et la dysphorie, seront convertis respectivement, et plus précisément, en 'désirable / indésirable' (/vouloir-être/), en 'indispensable / nuisible' (/devoir-être/), en 'possible / impossible' (/pouvoir-être/), etc..."
} 
interessava porque a teoria das modalidades estava no centro da intenção dos semioticistas de dar às paixões uma definição sintáxica, segundo deixa entrever a observação de Greimas (1978, p. $4^{12}$ ):

No final das contas, talvez não seja inútil insistir sobre uma evidência: a reflexão a respeito da semiótica das paixões deve ser levada paralelamente a um exame mais aprofundado da teoria das modalidades. Nossa tentativa nesse domínio (Langages, 43, 1976) constitui apenas um ponto de partida. A determinação do estatuto e do comportamento das modalidades convertidas e inscritas nas estruturas semionarrativas de superfície, o estabelecimento de sequências modais canônicas, constitutivas da competência dos sujeitos, a descrição do procedimento de conversão das modalidades-predicados em valores modais, condição de sua axiologização, parecem-nos tarefas urgentes.

Os anos seguintes foram, dessa forma, consagrados ao aperfeiçoamento da teoria modal. Era preciso não apenas identificar combinações modais nos afetos, mas sobretudo compreender os diferentes modos de articulação entre elas, o agenciamento sintáxico muitas vezes incompatível, contraditório e paradoxal, bem como o funcionamento da dinâmica de conversão que dá a um arranjo de modalidades efeitos passionais. 0 grande desafio era, como coloca Fontanille em seu artigo de 1986, intitulado "Le tumulte modal: de la macro-syntaxe à la microsyntaxe passionnelle", compreender o que se passa entre as modalidades, o dinamismo interno dos estados, de maneira que fosse possível estabelecer uma sintaxe de caráter intermodal. Isso explica a entrada do domínio da aspectualização nas pesquisas referentes ao exame dos núcleos passionais.

Nessa época de busca por maior compreensão do funcionamento das estruturas patêmicas, diversas investigações em torno de paixões tomaram lugar, seja a partir do ponto de vista dos lexemas-paixões, ou dos sintagmas narrativos realizados a partir de textos literários - a admiração (Thürlemann, 1980), o

${ }^{12}$ Trecho original: "En fin de compte, il n'est peut-être pas inutile d'insister sur une évidence: la réflexion sur la sémiotique des passions doit être menée de pair avec un examen plus approfondi de la théorie des modalités. Notre première tentative dans ce domaine (Langages, 43, 1976) n'en constitue qu'un point de départ. La détermination du statut et du comportement des modalités converties et inscrites dans les structures sémio-narratives de surface, l'établissement des suites modales canoniques, constitutives de la compétence des sujets, la description de la procédure de conversion des modalités-prédicats en valeurs modales, condition de leur axiologisation, nous paraissent comme des tâches urgentes. 
desespero (Fontanille, 1980), a cólera (Greimas, 1981), a indiferença (Marsciani, 1984), a nostalgia (Greimas, 1986), entre outros -, e ainda alguns poucos que já se aventuravam na representação das paixões a partir de estratégias discursivas da enunciação - Bertrand (1986, 2003) e Hénault (1986, 1994). Todas as análises, quaisquer que fossem seus pontos de vista, buscavam explorar as hipóteses da gramática narrativa e em especial os elementos levantados quando do estudo da manipulação, da ação, da sanção, e também da problemática da persuasão.

Entre essas publicações encontra-se ainda a proposição de Herman Parret (1982 e 1986) para uma tipologia morfológica das paixões - a partir de princípios de concatenação modal subjacentes às taxionomias fornecidas pelas línguas naturais -, muito criticada por se apresentar como apenas uma tradução semiótica do que já havia sido feito pelos filósosfos (MARSCIANI, 1982). Como explica Fontanille (2002a, p. $606^{13}$ ):

Greimas se esforçava para escapar, a qualquer custo, da tipologia das paixões e demonstrar a originalidade da abordagem semiótica em relação à tradição filosófica, que é sistematicamente taxionômica nesta matéria; a semiótica das paixões devia ser uma sintaxe, e a análise modal, principalmente como a praticava $\mathrm{H}$. Parret, verdadeiro filósofo que é, reconduzia parcialmente a semiótica das paixões em direção à taxionomia.

O estudo das paixões, e o objetivo de uma descrição sintáxica desse novo universo de significação, sobretudo no que diz respeito à compreensão do funcionamento da estrutura subjacente, foi pouco a pouco trazendo à cena a problemática do sensível na sua articulação com o inteligível. 0 avanço das pesquisas no domínio do passional e a busca constante de aperfeiçoamento da proposição semiótica para a criação de um modelo geral de análise das paixões assinalaram a participação do sentir, mesmo que os semioticistas não soubessem ainda o melhor modo de tratar a questão, no processo de significação. Não só a noção de sujeito, na sua estrita relação actancial com o objeto, ganha mais espaço

\footnotetext{
${ }^{13}$ Trecho original: “Greimas s'efforçait à tout prix d'échapper à la typologie des passions, et de démontrer l'originalité d'une approche sémiotique pas rapport à la tradition philosophique, qui est presque systématiquement taxinomique en cette matière; la sémiotique des passions devait être une syntaxe, et l'analyse modale, notamment telle la pratiquait H. Parret, en vrai philosophe, ramenait en partie la sémiotique des passions vers la taxinomie."
} 
dentro da teoria, mas também a de corpo - enquanto elemento de mediação proprioceptiva (percepção do corpo-próprio) para a homogeneização semiótica entre a apreensão extero- (percepção do mundo exterior) e interoceptiva (percepção do mundo interior) - e, consequentemente, a de percepção. De acordo com Fontanille (PORTELA, 2006, p. $166^{14}$ ):

O final dos anos 1980, uma vez colocada a teoria das modalidades, que faz a transição entre a semiótica narrativa e a do discurso, o seminário sobre as paixões, a virada "sensível" das pesquisas semióticas, a ascensão das abordagens fenomenológicas, é o momento em que nasce a semiótica que se faz hoje.

São duas as publicações de maior representação, e repercussão, dessa "virada rumo ao sensível" na qual embarca a semiótica, escritas quase que paralelamente: De l'imperfection (1987), de Greimas, e Sémiotique des passions (1991), de Greimas e Fontanille - traduzidos no Brasil em 2002 e 1993, respectivamente.

Em Da imperfeição (2002), Greimas, tendo ainda como base metodológica a teoria das modalidades, apresenta uma discussão sobre os modos de se apropriar da investigação relacionada à produção da significação na experiência estética a partir da articulação entre o inteligível e o sensível, lançando o conceito de estesia, referente à apreensão, à emoção estética que funde sujeito da percepção e objeto percebido. São os primeiros indícios da reflexão a respeito da emergência do sentido, das condições elementares de sua aparição, mais amplamente trabalhada em Semiótica das paixões (1993). Conforme aponta Lucia Teixeira (2002, p. 260), “é também com $D a$ Imperfeição que o campo do sensível retorna fortemente às preocupações dos semioticistas, não só como busca metafórica de fontes fenomenológicas, mas também como apelo à entrada do corpo sensível no universo da produção do sentido".

Alguns poucos anos depois, o livro Sémiotique des passions (1991) aparece com o objetivo de "balanço" dos resultados de pesquisa adquiridos até então. De

${ }^{14}$ Trecho original: "La fin des années 80 , une fois posée la théorie des modalités, qui faisait la transition entre la sémiotique du récit et celle du discours, c'est d'abord le séminaire sur les passions, le virage « sensible » des recherches sémiotiques, la montée en puissance des approches phénoménologiques, c'est le moment où prend naissance la sémiotique qui se fait aujourd'hui". 
acordo com Fontanille (2012), tratava-se da concepção de um projeto de síntese das aquisições e de perspectiva teórica.

Mesmo não sendo essa a intenção, essa obra marca uma grande mudança nos rumos da teoria, uma vez que a tentativa de esclarecer e estabelecer os princípios epistemológicos da semiótica das paixões trazia a necessidade de explicar de maneira coerente a geração das modalidades responsáveis pela descrição sintáxica dos afetos; ou seja, era preciso não apenas explicitar as condições estruturais dos núcleos patêmicos, mas também as pré-condições de configuração dessas unidades formais. Como explica Fontanille (1993a, p. 157 ${ }^{15}$ ): “[...] tornava-se inevitável recorrer a uma reformulação epistemológica de todo o edíficio teórico (ao invés de construir um outro edifício ao lado), mostrando como a semiótica podia dar conta da nova problemática e, ao mesmo tempo, avaliando o custo teórico da operação".

A partir de então, a preocupação dos semioticistas vai se voltar completamente às questões ligadas mais propriamente ao sensível, à participação do corpo-próprio, da percepção, na geração da significação. Assim, mais do que os estudos apresentados desde o início do interesse da semiótica pelos afetos, é a discussão contida no último livro individual de Greimas, $D a$ imperfeição, e nos capítulos inicias de Semiótica das paixões a responsável pela guinada da teoria rumo ao sensível. Contudo, se a problemática é levantada, sendo substancialmente apresentada sobretudo nas páginas introdutórias de Semiótica das paixões - que custou aos autores, segundo Fontanille (1993a, p. $157^{16}$ ), "dois anos inteiros de discussões, escrita e reescritas sucessivas" -, ela não aparece da mesma forma nas análises contidas nos capítulos seguintes do livro. De acordo com Landowski (2005, p. 98):

[...] esquecendo aparentemente as promessas da introdução e do capítulo inicial, [os autores] voltam a um estágio metodológico e teórico anterior, aquele da gramática narrativa dos anos 1970-80. Suas descrições desenvolvem-se quase que de modo integral no

\footnotetext{
${ }^{15}$ Trecho original: "[...] il devinait inévitable de procéder à une réfondation épistémologique de l'édifice tout entier (au lieu de bâtir un autre édifíce à côté), en montrant comment la sémiotique pouvait rendre compte de la nouvelle problématique et en évaluant le coût théorique de l'opération."

${ }^{16}$ Trecho original: “[...] deux années entières de discussions, d'écriture et réécritures successives."
} 
terreno modal, o que os conduz a privilegiar a tal ponto a dimensão do conhecer, o "cognitivo" em detrimento do "sensitivo", que finalmente a questão das formas da coabitação esperada entre essas duas dimensões não será retomada.

Nesse sentido, o sensível encontra espaço no quadro teórico da semiótica das paixões, mas o mesmo não acontece com o lugar que deveria ocupar também na metodologia concebida para o estudo dos afetos, pois o modelo de análise consagrado a partir desta publicação, como se sabe, é o esquema passional canônico, no qual o exame das modulações, responsáveis pelo estabelecimento da estrutura modal no nível narrativo, não está previsto. 0 próprio Greimas parecia ter ciência disso, conforme lembra Fontanille (PORTELA, 2006, p. 169 ${ }^{17}$ ): "ele me confidenciou um dia, comentando o subtítulo de Semiótica das paixões, 'dos estados de coisas aos estados de alma', que nesse livro, ele avaliava que nós tínhamos 'ficado devendo' aos estados de alma".

É bem verdade que nessa época a questão do sensível era ainda bastante frágil e mesmo hipotética, demandando estudos e desenvolvimentos mais detalhados, só apresentados posteriormente. Era preciso compreender "como articular o contínuo? Como tratar de modo imanente a energia e a intensidade? Como tratar de maneira coerente aquilo que parece irredutivelmente heterogêno? etc" (FONTANILLE, 1993a, p. $157^{18}$ ).

A inserção da problemática do sensível, ao impor, então, uma revisão dos princípios epistemológicos antes estabelecidos, acaba por elevar a afetividade ao estatuto de dimensão da atividade de linguagem, e, a partir daí, ela começa a interessar, e a ser pensada, enquanto componente geral da significação. Nas palavras de Fontanille (1995b, p. $186^{19}$ ):

\footnotetext{
${ }^{17}$ Trecho original: "Il m’a confié un jour, en commentant le sous-titre de Sémiotique des passions, " Des états de choses aux états d'âme », que dans ce livre, il estimait que nous avions " manqué les états d'âme »."

${ }^{18}$ Trecho original: "[...] comment articuler le continu? comment traiter en immanence l'énergie et l'intensité? comment traiter de manière isotope ce qui semble irréductiblement hétérogène? etc."

${ }^{19}$ Trecho original: "Tout se passe comme si une autre rationalité réclamait ses droits, et plus encore quand les manifestations du corps propre (la proprioceptivité, dans la terminologie sémiotique) s'imposent au discours et en modifient le cours; c'est alors une autre dimension du sujet qui s'affiche, non plus celle, seulement, qui est requise pour la réalisation des programmes narratifs, mais celle, plutôt, où s'affirme son identité de sujet et son sens d'être."
} 
Tudo se passa como se uma outra racionalidade reclamasse seus direitos, e mais ainda quando as manifestações do corpo-próprio (a proprioceptividade, na terminologia semiótica) se impõem ao discurso modificando o seu curso; é como uma outra dimensão do sujeito que se fixa, e não mais somente aquela que é requerida para a realização de programas narrativos, mas sobretudo aquela na qual se afirma sua identidade de sujeito e seu sentido de ser.

Essa nova direção das pesquisas marca a "virada fenomenológica" da disciplina, e faz com que os semioticistas passem a ser interessar cada vez mais pela questão do discurso em ato, do devir, da emergência do sentido. É aí que as noções de percepção, presença e tensividade vão ganhando mais força e relevância no quadro geral da teoria. Como explica Beividas (2011, p. 19), "tendo o sensível ganhado paulatinamente a primazia no concurso da emergência da significação, o afeto passa de efeito à 'razão' das razões do sentido".

De todo modo, se os estudos no campo do sensível, ou da afetividade enquanto dimensão, evoluíram e continuam em pleno desenvolvimento, o exame propriamente dos estados de alma não progrediu da mesma maneira. A metodologia oferecida e consagrada à análise semiótica das paixões permanece conforme ao esquema passional canônico, no qual a ênfase é dada à estrutura modal, enquanto o sensível e as noções daí advindas continuam a não encontrar o seu lugar. A investigação semiótica sobre a configuração dos afetos, mesmo reconhecendo as indicações e especificidades desse outro universo de significação, da ordem do sensível, que desde o início apontou para a necessidade de transpor a abordagem descontínua do sentido, integrando os aspectos contínuos próprios à articulação entre inteligível e sensível, como foi discutido na introdução de Semiótica das paixões (1993), continuou, pois, fundamentada sobretudo nas modalidades, responsáveis por instituir, reciprocamente, o estatuto do sujeito e do objeto.

Assim, a análise semiótica das paixões, na maioria das vezes, faz-se ainda hoje quase exclusivamente em termos de sintaxe modal, isto é, de dispositivos e combinações de modalidades que estruturam o estado do sujeito narrativo. 0 passional, no entanto, como apontam os próprios autores de Semiótica das paixões (GREIMAS; FONTANILLE, 1993), logo no início da obra, não é apenas uma 
organização sintagmática e modal, mas deve ser considerado também sobre o fundo de uma problemática tensiva e sensível, inerente à determinação fórica, tal como será proposto anos depois, por Fontanille e Zilberberg, em Tensão $e$ significação $\left(2001^{20}\right)$.

Em seu debate com Paul Ricoeur, em 1989, a propósito da semiótica das paixões, Greimas admite (HÉNAULT, 1994, p. 203 ${ }^{21}$ ): “[...] somos forçados, depois de muita hesitação (porque uma vez estabelecidos os princípios teóricos nós temos vontade de parar por aí), a reconhecer que o discurso se movimenta, que ele tem forças que não se explicam inteiramente pelas modalidades, que há algo mais".

\subsubsection{Das condições às pré-condições de configuração da interação passional}

O direcionamento da teoria semiótica rumo ao sensível, ao fenomenológico, a partir da inserção da problemática das paixões, fez com que a questão da emergência, ou melhor, das condições de emergência do sentido ocupasse o primeiro plano nos desenvolvimentos subsequentes da disciplina. 0 universo da experiência estésica, da semiose mediada pelo corpo-próprio, da interação afetiva do sujeito com o mundo percebido, ganhou voz, e o sensível passou a ter primazia sobre o inteligível. Ao contrário da "era do lógico", do categórico e do descontínuo imposta pelo estruturalismo dos anos 1960, o contínuo tomou o seu espaço, e com ele o crescente interesse pelo processo mais do que pelas unidades discretas, conforme assinala Fontanille (2007, p. 23):

[...] o estruturalismo postulou como princípio que somente os fenômenos descontínuos e as oposições chamadas "discretas" são inteligíveis e pertinentes. Isso sem considerar os processos de emergência e instalação desses fenômenos e dessas oposições, processos ao longo dos quais os fenômenos atravessam fases em que as modulações contínuas e as tensões graduais predominam. [...] Hoje, portanto, relativizaríamos a argumentação original e

\footnotetext{
${ }^{20}$ A publicação do original surge na França em 1998.

${ }^{21}$ Trecho original: “[...] on est forcé après moult hésitations (parce qu'une fois qu'on a établi des principes théoriques qui paraissent satisfaisants on a envie de s'y tenir), on est forcé de reconnaître que le discours, ça bouge, qu'il y a des forces qui ne s'expliquent pas entièrement par les modalités, qu'il y a autre chose."
} 
diríamos que, certamente, só as descontinuidades são inteligíveis, mas estas só o são completamente se levarmos em conta os processos que conduzem a elas. Isso significa que os processos são "pertinentes" tanto quanto as oposições discretas que deles resultam.

O contexto atual da semiótica está, nesse sentido, marcado pela constante preocupação com a esquematização da significação em devir, despertando o interesse dos estudiosos por temas de pesquisa que haviam sido antes descartados em nome dos princípios do estruturalismo, por exemplo, aqueles relativos à noção de percepção (com seus funtivos interoceptivo, exteroceptivo, proprioceptivo) e de timia (própria à ideia de atração e repulsão).

Esses temas, intimamente relacionados, já presentes desde a fundação da teoria, no caso da percepção, e desde os primórdios da investigação sobre as paixões, no caso da timia, foram inicialmente tratados de forma bastante pontual, como pressupostos lógicos, uma vez que, constatada a sua participação nas condições de configuração dos componentes formais estudados, não podiam ser de todo descartados. Embora a questão das circunstâncias mínimas de emergência do sujeito apaixonado tenha se colocado desde o início do estudo das paixões, ela só vai aparecer com mais força e de maneira mais explícita na introdução do livro Semiótica das paixões (1993 [1991]), e mesmo assim vinculada a um desenvolvimento metodológico, como dito anteriormente, no qual a articulação entre o sensível e o inteligível não está totalmente prevista. Segundo Mancini (2006, p. 10, 11):

O conceito de modalização trouxe ganhos inegáveis ao modelo, apesar de ter passado um tanto ao largo de uma série de questões pendentes que sequer haviam chegado a uma boa formulação. Talvez seja esse o principal mérito de Semiótica das Paixões: nessa obra, Greimas, juntamente com Jacques Fontanille, dão a devida ênfase ao problema da continuidade, trazendo para primeiro plano o universo sensível e suas configurações passionais. Entretanto, apesar da inegável pertinência dos conceitos e propriedade no modo de apresentá-los, as questões ainda foram tratadas de modo bastante intuitivo, uma vez que, naquele momento, não haviam sido desenvolvidas as ferramentas conceituais necessárias à sua formalização. 
A combinação modal ocupa, sem dúvida, um papel fundamental no estudo das paixões, porque define a identidade, o ser do sujeito narrativo e o conflito que caracteriza seus "estados de alma"; ela torna possível a depreensão das fases da manifestação afetiva enunciada e o seu papel na produção de uma dada paixão. As modalidades estão no centro da estrutura de configuração dos afetos, "traduzindo" a interação estabelecida entre sujeito apaixonado e objeto da paixão; mas sozinhas, elas nada dizem a respeito do "excesso" propriamente dito, das modulações tensivas que subjazem às articulações modais e sensibilizam a interação, o esquema narrativo como um todo. Conforme salientam Greimas e Fontanille (1993, p. 21):

Uma primeira constatação impõe-se: a sensibilização passional do discurso e sua modalização narrativa são co-ocorrentes, não se compreendem uma sem a outra, e, no entanto, são autônomas, submetidas, provavelmente, ao menos em parte, a lógicas diferentes.

Mesmo ao explorar a dimensão patêmica dos textos, a investigação sobre os elementos constitutivos de uma dada paixão, quando presa unicamente à estrutura modal, fica limitada aos conteúdos inteligíveis da configuração, porque as modalidades, colocadas como peças-chave da análise, dizem respeito ao encadeamento sintáxico dos dispositivos atuantes no nível narrativo, não podendo ajudar no exame do componente propriamente sensível que o engendra. Os autores advertem (Idem, p. 68): “os efeitos de sentido passionais não podem encontrar explicação satisfatória apenas no seio do nível semionarrativo", e explicam: "os dispositivos modais pertencem de direito ao semionarrativo; constituem 'realizáveis' do esquema semiótico, mas as paixões que deles se nutrem constituem-se de fato no seio no nível discursivo" (Idem, p. 69). Os semioticistas acrescentam ainda (Idem, p. 90):

Elaborar uma semiótica das paixões é, portanto, tomar o partido de uma representação da dimensão narrativa dos discursos que não se reduz a uma espécie de lógica da ação nem a uma concepção do sujeito que seria inteiramente determinado por seu fazer e pelas condições necessárias para realizá-lo. 
Para que se possa, pois, compreender a estruturação discursiva da paixão, é preciso atentar tanto à articulação modal quanto ao aspecto propriamente sensível da configuração patêmica, das modulações tensivo-fóricas responsáveis pela sensibilização das modalidades em questão, indo além da ideia (ou da pressuposição lógica) de um "excedente modal”, de uma intensidade subjacente. De grande importância à análise dos afetos, a observação relativa à foria - entendida como aspectualização no nível discursivo e como modulação tensiva no nível profundo - propicia o exame do desenvolvimento contínuo e progressivo do núcleo passional, ou seja, das modulações articuladas à direção tensiva que conduz e controla o encaminhamento discursivo, uma vez que a dimensão fórica perpassa todo o percurso gerativo, configurando o elemento sensível junto ao processo discursivo. A esse propósito, Fontanille (2007, p. 184) explica:

[...] a teoria das modalidades foi o primeiro passo na direção de uma semiótica das paixões: os efeitos passionais, graças ao componente modal oriundo da narratividade, tornam-se analisáveis, cada efeito passional podendo ser reduzido, de um ponto de vista narrativo, a uma combinação de modalidades. Portanto, os afetos passionais eram considerados como simples epifenômenos do percurso narrativo dos actantes. Todavia essa abordagem do domínio afetivo permanecia nos limites de uma lógica das transformações, a lógica do discurso-enunciado. Fica bem claro, no entanto, que a dimensão afetiva do discurso não pode ser privada da presença, da sensibilidade e do corpo que toma posição na instância do discurso, pois a afetividade reivindica o corpo do qual ela emana e o qual ela modifica.

A problemática do sensível, como se pode entrever, não é apenas uma questão de nível de pertinência, pois ela atravessa de uma ponta a outra a geração da configuração passional, estando intrinsecamente ligada às condições de sua estruturação. São as operações subjacentes às modalidades, do domínio das modulações, que as predispõem a participar das configurações patêmicas reconhecíveis em determinada cultura. Como admite Fontanille (1993a, p. 15722), “[...] anteriormente a sua discretização sob a forma de determinações do nível semio-narrativo, as modalidades são variações calculáveis no seio do espaço

\footnotetext{
${ }^{22}$ Trecho original: “[...] antérieurement à leur discrétisation sous la forme de déterminations du niveau sémio-narratif, les modalités sont des variations calculables au sein d'un espace tensif."
} 
tensivo".

O exame das modulações, dessa forma, diretamente ligado ao devir da interação passional, a partir da inserção dos valores no campo de presença do sujeito, refina e aprofunda o estudo dos afetos em semiótica, podendo, então, ultrapassar os limites do discurso-enunciado e examinar a configuração passional no momento de sua emergência, no domínio do discurso em ato, da articulação entre o sensível e o inteligível.

É por isso que, de nossa parte, retomando: (i) a discussão apresentada nas páginas introdutórias de Semiótica das paixões ${ }^{23}$ (1993), (ii) reexaminada em Tensão e significação (FONTANILLE; ZILBERBERG, 2001, p. 293-319), quando ela ganha um tratamento mais formal, (iii) e em diversos outros textos de Fontanille e Zilberberg, pretendemos propor a reformulação do esquema passional canônico a partir de um ponto de vista tensivo, de modo que o modelo de análise semiótica das paixões evolua par a par com os desenvolvimentos atuais da teoria. A ideia é apresentar uma (re)formulação metodológica da teoria já esboçada na introdução de Semiótica das paixões (1993), desta vez, com a percepção ocupando o papel de "pedra angular" na produção dos afetos.

Acreditamos que além do exame das características da dimensão passional nos níveis narrativo e discursivo, o modelo de análise proposto deve dar conta também das condições de geração destas especificidades, da base tensivo-fórica subjacente, concebendo a paixão como resultado de correlações ao mesmo tempo sensíveis e inteligíveis. Nesse sentido, em nossa proposta, a paixão será entendida, antes de mais nada, como resultante de um determinado modo de interação, caracterizado a partir de peculiaridades próprias à experiência (perceptiva) entre o sujeito da percepção e o objeto percebido. Trata-se da apresentação de uma semiótica das paixões fundamentada nas estruturas elementares da significação, com o sujeito do afeto constituindo-se como um algoritmo da percepção (DISCINI, 2011).

Um exame das paixões que leve em conta o componente propriamente sensível, na sua articulação com o inteligível, parece válido, segundo acreditamos,

\footnotetext{
${ }^{23}$ Estamos nos referindo aqui tanto ao conteúdo da "Introdução", quanto do capítulo 1, intitulado "A epistemologia das paixões".
} 
por permitir concebê-las na própria emergência passional da relação intersubjetiva, depreendendo, para além das características de um perfil, as condições enunciativas - de produção e de captação - do acontecimento passional, bem como uma maior compreensão das especificidades de instauração dos diferentes modos de interação entre o sujeito e aquilo que se põe em seu campo de presença, do(s) elemento(s) responsável(is) pelas distintas formas de reação afetiva ao contato com o outro.

\subsection{Entre o sensível e o inteligível: os diferentes modos de interação}

Michel Meyer (2000), em seu prefácio ao livro Retórica das paixões (2000), de Aristóteles, parte das observações feitas pelo filósofo grego em seus apontamentos sobre os afetos para chamar a atenção ao caráter interativo da dimensão patêmica, compreendendo a paixão como representação e reação ao outro. Para ele, "paixão é resposta, julgamento, reflexão" (p. xxxix).

Mesmo com base em um quadro epistemológico diferente daquele em que se fundamenta a teoria semiótica de linha francesa, o ponto de vista do autor em questão interessa por dois motivos: (i) por ressaltar o papel da interação na constituição de uma paixão, permitindo que, em um nível mais abstrato, os afetos sejam entendidos como resultantes do devir da ligação interactancial, e (ii) porque chama a atenção para a estreita ligação entre sensível e inteligível no momento dessa interação. Há um estímulo que afeta o sujeito (convocando-o de alguma maneira) e provoca nele determinada "resposta" (sensível-inteligível), certo modo de interação.

Para a semiótica, os sujeitos participam de dois tipos de relações: entre sujeito e objeto, simulando a ação do homem sobre o mundo; e entre sujeitos, destinador e destinatário, referente à atividade de comunicação, compreendida como forma de manipulação que conjuga um fazer persuasivo e outro interpretativo (BARROS, 2003). Até final dos anos 1980, antes da virada fenomenológica da disciplina, foi esta última que a teoria considerava e explorava 
como forma de interação. Com o advento do sensível, no entanto, outras propostas surgiram, e entre elas a de Eric Landowski (2004; 2006), que passa a conceber a interação como uma relação, sobretudo, sensível, estésica, entre actantes, a partir da qual se engendra a significação. Como coloca o autor citado $\left(2004\right.$, p. $\left.5^{24}\right)$ : “até o momento, analisávamos significações articuladas, consideradas como da ordem do inteligível e do cognitivo, mas agora a questão é tomar por objeto um sentido que seria da ordem do sensível e do afetivo".

Landowski, ao partir, então, dos apontamentos feitos por Greimas em $D a$ imperfeição (2002), propõe uma teoria sociossemiótica das interações, cuja tarefa é a de explorar os modos de significação do sensível na relação interactancial face a face, corpo a corpo, no momento de emergência do sentido, quando surgem todo tipo de pequenas paixões, de "paixões sem nome". De acordo com ele (LANDOWSKI, 2004), nossa relação com o mundo, e com os outros, inscreve-se na discursividade de regimes de presença e de interação subjacentes a nossa maneira de ser no mundo e de interagir (estesicamente) com aquilo que nos rodeia.

Apresentando o que chama de uma semiótica da experiência, do vivido, de práticas significantes em ato e constituídas no momento da interação, o semioticista discute a existência de diferentes "regimes de produção do sentido" que estariam relacionados aos modos de significação do sensível, à "experiência de um sentido procedente diretamente do nosso encontro com as qualidades sensíveis imanentes às coisas presentes" (2004, p. $\left.2^{25}\right)$. Trata-se, como ele explica, (Idem, p. $5^{26}$ ), de "descrever semioticamente a maneira pela qual o componente sensível - estésico - intervém na apreensão do sentido in vivo, isto é, em ato, em situação". Dessa forma, embora assinale a ligação intrínseca e indissociável entre inteligível e sensível, a proposição do autor, fundada exclusivamente no efeito das qualidades sensíveis investidas na materialidade dos seres e das coisas e na competência estésica dos sujeitos, deixa de lado, a nosso ver, a problemática da

\footnotetext{
${ }^{24}$ Trecho original: "Jusqu'à présent, on analysait des significations articulées, considérées comme de l'ordre de l'intelligible et du cognitif, et voici qu'il est donc maintenant question de prendre pour objet un sens qui serait de l'ordre du sensible et de l'affectif."

${ }^{25}$ Trecho original: "[...] l'expérience d'un sens procédant directement de notre rencontre avec les qualités sensibles immanentes aux choses présentes."

${ }^{26}$ Trecho original: "[...] décrire sémiotiquement la manière dont la composante sensible - esthésique

- intervient dans la saisie du sens in vivo, c'est-à-dire en acte et en situation."
} 
articulação entre as duas dimensões, e privilegia a análise do sensível em detrimento de sua ligação com o inteligível.

Com uma concepção de interação que está bem próxima à da ideia landowskiana, diríamos, de nossa parte, que, para a compreensão e descrição semiótica dos afetos, interessa agora examinar não só "a maneira pela qual o componente sensível - estésico - intervém na apreensão do sentido in vivo" (LANDOWSKI, 2004, p. 5), mas sobretudo a forma pela qual se articulam o sensível e o inteligível no momento da interação entre sujeito e objeto. Propomos, para isso, partir da análise das circunstâncias de configuração da interação, por acreditarmos estar nelas a "chave" para a compreensão das especificidades da conexão entre sensível e inteligível; e essas "circunstâncias de configuração da interação" seriam, a nosso ver, determinadas pelas condições de percepção, no momento exato em que se estabelece a coexistência interactancial.

Nesse sentido, o que temos chamado modos de interação está, como pretendemos demostrar, intimamente relacionado à problemática dos modos de presença - segundo a concebe a vertente tensiva -, aos modos de convocação e de articulação do sensível e do inteligível no momento de emergência da significação e da afetividade, entendendo a interação não só como uma relação de comunicação em que se privilegiam as atividades persuasiva e interpretativa, mas também como aquela que se fundamenta em uma relação de transitividade perceptiva entre sujeito (da percepção) e objeto (percebido). Afinal, como explica Mancini (2006, p. 5), "o sujeito constrói o objeto com sua percepção e, ao fazê-lo, constrói a si mesmo como sujeito daquela percepção".

Diferentemente da proposta landowskiana que, em função da perspectiva sociossemiótica, examina o processo de configuração da experiência, das condições de emergência do sentido na interação, a partir de práticas sociais diversas, "de maneiras socialmente atestadas de construir o sentido" (LANDOWSKI, 2006, p. $10^{27}$ ), com o modelo de análise sugerido atendo-se aos traços estruturais dos níveis mais superficiais, ou seja, a organização narrativa e os efeitos de sentido produzidos por sua aspectualização, fundamentaremos nossa proposta de análise

\footnotetext{
${ }^{27}$ Trecho original: [...] de rendre compte des manières socialement attestées de construire le sens $[\ldots]^{\prime \prime}$
} 
dos diferentes modos de interação nos desenvolvimentos oferecidos pela semiótica tensiva, defendendo não a ênfase da influência do sensível, do estésico, na configuração da relação interactancial, mas a ligação inerente dele com o inteligível no momento da percepção, da emergência da interação entre actante sujeito e actante objeto.

Essa maneira de conceber a noção de interação nos parece válida na medida em que expande esse conceito, dentro do quadro teórico da semiótica francesa, para além da manipulação e da interação verbal entre destinador e destinatário, e por assinalar de vez a relação intrínseca entre sensível e inteligível na produção da significação, dos afetos daí advindos. Em todo caso, antes de continuar a tratar da questão da interação propriamente dita, ou mais especificamente, de seus modos de instauração, é importante deixar claro o que estamos entendendo neste trabalho como percepção, uma vez que, herdeira da perspectiva fenomenológica, a noção ainda não encontra consenso entre os semioticistas.

\subsubsection{Sobre a noção de percepção em semiótica}

Se, por um lado, os semioticistas em geral veem a atividade perceptiva como lugar por excelência das pré-condições da significação, com o sensível regendo o inteligível, por outro, eles se dividem entre os que, ao seguir a concepção dualista sensação vs. cognição; sentir vs. conhecer - ditada pela tradição filosófica, a consideram unicamente como atividade sensorial a partir da qual se inicia o processo de categorização, e aqueles que a compreendem como momento por excelência da articulação do sensível com o inteligível, no qual já se opera a semiose.

Para este trabalho, tomaremos o partido do segundo grupo, com nossas proposições assentadas na concepção de percepção apresentada nos trabalhos de Fontanille - em especial o artigo "La base perceptive de la sémiotique", publicado em 1995b, e o livro Semiótica do discurso, de 2007 [2003] -, cujo teor parece já fluidamente esboçado na introdução de Semiótica das paixões (GREIMAS; 
FONTANILLE, 1993) com a ideia do "processo de homogeneização da existência semiótica" pelo corpo-próprio (Idem, p. 13).

No texto de 1995b, Fontanille, colocando lado a lado as perspectivas fenomenológica e semiótica - sem esquecer de assinalar as diferenças epistemológicas de uma e outra -, define a percepção como ato, como momento no qual se configuram, a partir da relação intrínseca entre sensível e inteligível, as précondições da significação. Para ele, o conhecimento se constroi no ato perpceptivo, quando a apreensão sensível transforma o mundo em mundo significante.

A partir desta perspectiva, o que o semioticista citado propõe é a formalização semiótica da base fenomenológica da percepção, destacando: "tratase da necessidade de desenvolver uma epistemologia linguística, ou seja, uma epistemologia atenta ao fato de que o sujeito da percepção é um ser de linguagem, um ser social e cultural" (1995b, p. a ${ }^{28}$ ). Nesse sentido, a intenção dele é a de:

[...] considerar a percepção não como um universal analisável em operações do "espírito humano", mas como um conjunto de parâmetros suscetíveis de variações e, sobretudo, de inflexões culturais: no momento mesmo em que a percepção produz a categorização semiolinguística, ela se especifica no interior de um idioleto ou um socioleto (1995b, p. a ${ }^{29}$ ).

Dito isto, é preciso então compreender, semioticamente, como se dá esse processo de construção da significação, de passagem das qualidades sensíveis à apreensão inteligível no momento da percepção; e, mais especificamente, no panorama que nos interessa, no da configuração dos afetos, avaliar como esse processo faz surgir uma significação passional, ou, se assim parecer melhor, uma apropriação patemizada da significação, um modo de interação afetiva entre o actante sujeito perceptivo e o actante objeto percebido.

Para essa tarefa, Fontanille (1995b) propõe a utilização de parâmetros tensivos, nos quais as noções de profundidade, presença e modulações qualitativas,

${ }^{28}$ Trecho original: "[...] il s'agit encore et toujours de développer une épistémologie linguistique, c'est-à-dire une épistémologie qui n'oublie jamais que le sujet de la perception est un être de langage et un être social et culturel."

29 Trecho original: "[...] considérer la perception non pas comme un universel analysable en opérations de l'“esprit humain”, mais comme un ensemble de paramètres susceptibles de variations et, notamment, d'infléchissements culturels: au moment même où elle engendre la catégorisation sémio-linguistique, la perception se spécifie à l'intérieur d'un idiolecte ou d'un socielecte." 
da ordem da intensidade, e quantitativas, da ordem da extensidade, mostram sua coerência operacional. Segundo o autor (2007, p. 47):

Perceber algo - antes de reconhecer esse algo como uma figura pertencente a uma das macrossemióticas - é perceber mais ou menos uma presença. De fato, antes de identificar uma figura do mundo natural, ou ainda uma noção ou um sentimento, percebemos (ou "pressentimos") sua presença, ou seja, algo que, por um lado, ocupa uma certa posição (relativa a nossa própria posição) e uma certa extensão e que, por outro lado, nos afeta com alguma intensidade. Algo, em suma, que orienta nossa atenção, que a ela resiste ou a ela se oferece.

Assim, perceber o mundo não é apenas sentir a sua presença, mas é também agir sobre ele, é interagir, concebendo-o de modo próprio por meio de uma atividade enunciativa discretizante, e já interpretante, do contínuo tensivo. Conforme explica o semioticista no texto de 1995 b (p. a6 $6^{30}$ ), "o espaço tensivo é um espaço semiótico organizado a partir de uma relação de percepção, a partir de uma visada que instala um centro de orientação deictizante e um mundo deictizado". Ele acrescenta (p. a $24^{31}$ ), "um sujeito perceptivo está imerso, enquanto corpo que sente, em tensões, a partir das quais ele vai realizar uma série de atos constitutivos do sentido". 0 percebido toma forma, pois, no momento da percepção.

Em Semiótica das Paixões (1993, p. 38-39²), Greimas e Fontanille afirmam:

[...] o sujeito operador convoca uma posição que, a partir de uma sombra de valor, delimita a zona de uma categoria; essa somação é ela mesma uma negação, ou melhor, uma apreensão, uma parada nas flutuações da tensão. Com efeito, o mundo como valor oferecia-se inteiro ao sentir do sujeito tensivo; mas para conhecêlo é preciso parar sua evolução contínua, isto é, generalizar o "encerramento" - eis a fonte da primeira negação -, circunscrever uma zona, convocar uma posição, ou seja, negar aquilo que não é essa posição. [...] essa é a condição para que, mediante a introdução do descontínuo no contínuo, o sujeito possa, por trás das sombras de valor, conhecer o objeto.

A presença é, portanto, "o correlato perceptivo de uma grandeza puramente

\footnotetext{
${ }^{30}$ Trecho original: “[...] l'espace tensif est un espace sémiotique organisé autour d'un rapport de perception, à partir d'une visée qui installe un centre d'orientation déictisant et un monde déictisé."

${ }^{31}$ Trecho original: "Un sujet perceptif est plongé, en tant que corps sentant, au sein de ces tensions, où il va accomplir une série d'actes constitutifs du sens".

${ }^{32}$ Para esta passagem, recorremos a uma tradução própria do original em francês (1991, p. 40-41).
} 
sensível" (FONTANILLE; ZILBERBERG, 2001, p. 135); ou seja, é um “recorte”, pela percepção, do mundo enquanto continuum tensivo, da qualidade puramente sensível que passa a se apresentar ao sujeito transformada em presença. Trata-se, portanto, de um primeiro modo de ação, uma "intuição categorial", nos termos de Husserl (1970); mesmo porque, ainda segundo os autores de Semiótica das paixões (1993, p. 39), "sem a contradição, a somação determinaria apenas uma pura singularidade no contínuo tensivo e fracassaria em fazer advir a significação", uma vez que "o primeiro abalo do sentido não é suficiente ainda para engendrar a significação" (Idem, p. 29).

O sujeito perceptivo é, pois, agente, ele faz-ser o mundo a seu redor, porque toda percepção, ao convocar o sentir do sujeito, pela experiência sensível da apreensão de uma presença, invoca também, como ato, uma forma de intencionalidade, de "decifração" lançada sobre o percebido pela projeção cognitiva da identificação de traços distintivos inerentes que discriminam o indistinto. De acordo com Bordron (2002, p. 640, tradução nossa ${ }^{33}$ ), "não podemos perceber sem responder à percepção. Uma percepção sem resposta equivale ao efeito mecânico de um corpo sobre outro, efeito que não se pode considerar como percebido". Ele acrescenta (Idem, p. 657 ${ }^{34}$ ): “[...] uma percepção, na medida em que se queira opor esse termo ao de sensação, culmina na forma predicativa do julgamento".

Uma vez apreendidos esses valores diferenciais, ou essa "sombra de valor" para usar o termo apresentado em Semiótica das paixões (1993), o sujeito, como ser de linguagem, no movimento proprioceptivo que vai da exterocepção à interocepção, e vice-versa, parte para uma tentativa de categorização dos traços distintivos percebidos, traduzindo-os então em significantes da língua natural, em valores semânticos. É nesse momento que o sujeito perceptivo se transforma em sujeito da enunciação e a percepção se vê submetida aos universos culturais, fazendo surgir o "valor do valor", ou seja, o valor que o sujeito passa a atribuir ao valor diferencial imposto, que, em sua disposição (dispersão/coesão) e modo de

\footnotetext{
${ }^{33}$ Trecho original: “[...] on ne peut percevoir sans répondre à la perception. Une perception sans réponse équivaut à l'effet mécanique d'un corps sur un autre, effet dont il n'y a aucune raison de dire qu'il est perçu"

${ }^{34}$ Trecho original: "[...] une perception, pour autant que l'on veuille opposer ce terme à celui de sensation, culmine dans la forme prédicative du jugement".
} 
aparição (átono/tônico), determina as especificidades de configuração do campo de presença, os modos de articulação da experiência sensível (da ordem da intensidade) com o processamento inteligível (da ordem da extensidade). Conforme esclarecem Greimas e Fontanille (1993, p. 13):

Observou-se que os traços, as figuras, os objetos do mundo natural, de que constituem por assim dizer o "significante", achamse transformados, pelo efeito da percepção, em traços, figuras e objetos do "significado" da língua, substituindo-se ao primeiro um novo significante, de natureza fonética. É pela mediação do corpo que percebe que o mundo transforma-se em sentido - em língua -, que as figuras exteroceptivas interiorizam-se e que a figuratividade pode então ser concebida como modo de pensamento do sujeito.

Esse processo de conversão simultânea é associativo e dirigido pela apreensão da presença; atividade de linguagem que une um plano de expressão a um plano de conteúdo, fazendo da atividade perceptiva um ato de semiose. A apreensão das qualidades sensíveis pelo sentir, é, sem dúvida, o elemento-chave, o desencadeador da atividade perceptiva; mas a sua articulação ao inteligível também está aí inscrita, porque o contato primeiro com o mundo na qualidade de presença se estabelece pela assimilação de descontinuidades diferenciais que adquirem o estatuto de valores opositivos - no sentido saussuriano - dentro do campo de presença instaurado entre o sujeito que percebe (centro de orientação) e o que é percebido (espaço deictizado).

A percepção do sujeito é, assim, sempre orientada por determinações tensivas que, por sua vez, vão responder pelas condições de acesso ao valor apreendido, isto é, ao mundo enquanto valor significante. Como dimensões constitutivas da nossa apreensão do "real", como formas complementares de um mesmo saber sobre o mundo, sensível e inteligível estão, portanto, irremediavelmente ligados no momento da percepção, e a diferença entre os modos de interação que daí surgem repousa, pois, segundo cremos, na ênfase que eles atribuem, respectivamente, à convocação do sensível e do inteligível na relação intersubjetiva. 


\subsubsection{Do valor ao afeto: o modo de convocação e a produção do "valor do valor"}

Mais do que esse percurso de conversão que faz da atividade perceptiva, pela mediação do corpo-próprio, um ato de semiose, acreditamos ser exatamente os modos de aparição dos valores diferenciais no campo de presença do sujeito os responsáveis pela carga patêmica configurada na interação perceptiva. Trata-se das (pré-)condições de produção do valor tímico-axiológico que será dado pelo actante sujeito ao valor virtual que lhe é imposto, o "valor do valor", elemento central, segundo cremos, para a emergência das interações afetivas. Não é, portanto, o valor investido no objeto, caracterizando-o como presença e, portanto, como objetovalor, que afeta o sujeito da percepção e desencadeia determinado modo de interação entre eles, mas sim a maneira peculiar pela qual esse valor, ao definir certa densidade de presença, surge no campo perceptivo e incita a interação, o modo de articulação do sensível com o inteligível.

A própria definição de presença, ou melhor, de campo de presença, tal como a apresenta a perspectiva tensiva, mostra que a noção de interação está aí implicada, pois que ela remete:

- à coexistência do sujeito e do objeto-valor, instaurando um território tensivo no qual atua a percepção;

- ao domínio espaço-temporal orientado por uma atividade perceptiva, no qual a tensão aumenta ou diminui, concentra-se ou distende-se com a profundidade, instituindo, reciprocamente, uma densidade de presença;

- à transitividade (perceptiva) entre sujeito e objeto-valor, permeada por modulações tensivas que articulam o sensível e o inteligível no ato perceptivo.

A interação - tanto quanto o campo de presença - concebida como fenômeno tensivo, é, portanto, a resultante, o efeito de sentido produzido por um espaço- 
tempo instaurado e compartilhado em ato, no e pelo momento mesmo no qual sujeito da percepção e objeto-valor percebido entram em relação. É por isso que, nesta tese, campo perceptivo e campo de presença não se confundem. 0 primeiro é anterior à instauração da interação e diz respeito ao sujeito na sua "abertura ao mundo", que ele traduzirá, no ato de percepção, no momento da coexistência, em mundo significante; o segundo é, por sua vez, exatamente esse espaço de coexistência do sujeito perceptivo e a presença que ele percebe, que se constitui como objeto-valor; é o "palco" da atividade perceptiva, no qual o processo de interação, de emergência da significação, desenrola-se e configura-se. Como esclarecem Fontanille e Zilberberg (2001, p. 129):

\begin{abstract}
A profundidade espácio-temporal proporciona à presença um devir e uma extensão; ela permite além disso, na medida em que é sempre passível de se contrair ou se estender, de recuar ou avançar os horizontes, uma perspectivação da presença e da ausência, uma em relação a outra, de sorte que o campo de presença aparece modulado [...]
\end{abstract}

A correlação entre intensidade e extensidade funciona, dessa forma, como gradiente de controle da percepção, da apreensão da presença. Conforme pontua Fontanille (2002a, p. $635^{35}$ ), “a estrutura tensiva está para a presença assim como o quadrado semiótico está para a junção: é uma estrutura elementar". É no contato primeiro com o objeto que se instauram as (pré-)condições para a configuração da significação, para a emergência do sentido enquanto resultado da interação (perceptiva) entre sujeito e objeto-valor, e nossa hipótese é a de que são exatamente as variações das características, quali e quantitativas, da presença, apreendidas, e definidas, pelo sujeito da percepção, as peças centrais para a compreensão das circunstâncias de geração dos modos de interação, por ser elas as determinantes do grau de atuação do sensível e do inteligível envolvidos nesse processo.

De acordo com Fontanille (1995b, p. a2436), “o corpo-próprio do sujeito

\footnotetext{
${ }^{35}$ Trecho original: "[...] la structure tensive est à la présence ce que le carré sémiotique est à la jonction : une structure élémentaire."

${ }^{36}$ Trecho original: "le corps propre du sujet perceptif est soumis aux tensions de l'espace qu'il déictise, et aux effets de la densité de présence dans la profondeur: la phorie désigne l'ensemble de ses réactions consécutives".
} 
perceptivo é submetido às tensões do espaço que ele deictiza, e aos efeitos da densidade da presença na profundidade: a foria designa o conjunto de suas reações consecutivas". Como ele esclarece em Semiótica do discurso (2007, p. 49), "de um ponto de vista semiótico, considera-se, em geral, que essas formas preliminares são esquematizações, no sentido empregado por Kant: a diversidade das substâncias sensíveis é submetida a uma pressão que as estabiliza e que lhes confere identidade e regularidade".

O campo tensivo, concebido como espaço esquemático, é, pois, o meio por excelência para a depreensão dos modos de configuração das interações. Nele, as diferentes possibilidades de constituição da presença funcionam como dimensões constitutivas da figuralidade patêmica, isto é, "uma perspectiva dinâmica no tratamento das relações juntivas, na medida em que põe em evidência a determinação recíproca operante entre os polos actanciais sujeito e objeto" (MANCINI, 2006, p. 11).

Se a presença é "uma primeira articulação semiótica da percepção" (FONTANILLE, 2007, p. 47), e se ela não pode ser senão relacional e tensiva, ou seja, "presença de x a y" (FONTANILLE; ZILBERBERG, 2001), podemos, então, estabelecer, com base em premissas já dadas pela semiótica tensiva, que a interação com aquilo que se põe no campo perceptivo do sujeito será: (i) mais da ordem do sensível quando a distância entre ele e o objeto percebido, em termos de profundidade, for menor, e, neste caso, a inserção dos valores investidos no objeto da percepção se fará de modo tônico e acelerado, num espaço e tempo compactados, resultando em um maior impacto estésico e uma menor capacidade de processamento inteligível, com resposta patêmica da ordem do acontecimento; ou, por outro lado, (ii) mais da ordem do inteligível, quando a distância no campo de presença for maior, com a inserção dos valores que caracterizam o objeto percebido configurada de modo átono e desacelerado, num espaço e tempo distribuídos que possibilitam um menor impacto estésico sobre o sujeito da percepção e um maior potencial de tratamento inteligível, com a reação afetiva sendo da ordem da implicação.

No caso de uma interação regida pela relação conversa entre as valências de 
intensidade (andamento e tonicidade) e de extensidade (espaço e tempo) haverá, no espaço tensivo, acreditamos, um equilíbrio entre sensível e inteligível, que tornará homogênas as dimensões afetiva, cognitiva e pragmática (ou factitiva), neutralizando a carga patêmica da interação. Por esse motivo, nesta tese, que tem como centro de interesse a configuração semiótica dos afetos, exploraremos somente a relação inversa entre intensidade e extensidade.

Em resumo, como ilustrado a seguir (cf. Tabela 1.1), quanto mais concentrada se configura a profundidade do campo de presença, maior será a densidade de presença do objeto percebido e, consequentemente, a força, o impacto que o valor nele investido exercerá sobre a reação sensível do sujeito da percepção, instituindo, portanto, uma interação de forte emoção; ao contrário, quanto mais difuso for o espaço tensivo da co-presença entre os actantes, menor a convocação sensível e maior a atuação da inteligibilidade do sujeito da percepção, o que instaura uma interação de fraca sensibilização emocional, uma emoção "intelectualizada". Lembrando que, nos dois casos, a ideia é apenas de uma dominância, seja do sensível sobre o inteligível, ou vice-versa.

\begin{tabular}{|c|c|}
\hline Interações mais sensíveis & Interações mais inteligíveis \\
\hline menor distância entre sujeito e objeto & maior distância entre sujeito e objeto \\
\hline $\begin{array}{c}\text { inserção dos valores de maneira } \\
\text { tônica e acelerada }\end{array}$ & $\begin{array}{c}\text { inserção dos valores de maneira } \\
\text { átona e desacelerada }\end{array}$ \\
\hline $\begin{array}{c}\text { maior densidade de presença do que é } \\
\text { percebido e menor densidade de } \\
\text { presença daquele que percebe }\end{array}$ & $\begin{array}{c}\text { menor densidade de presença do que é } \\
\text { percebido e maior densidade de presença } \\
\text { daquele que percebe }\end{array}$ \\
\hline espaço-tempo compacto & espaço-tempo difuso \\
\hline Forte convocação sensível & Fraca convocação sensível \\
\hline menor apreensão inteligível & maior apreensão inteligível \\
\hline afetividade da ordem do acontecimento & afetividade da ordem do exercício \\
\hline
\end{tabular}

Tabela 1.1: Classificação dos modos de interação a partir de especificidades sintáxicas de base (elaboração nossa). 
A emoção, "unidade elementar do sensível" (FONTANILLE; ZILBERBERG, 2001, p. 278), ápice afetivo, desempenha aí o papel de reação, de resposta (corporal) ao modo de inserção dos valores, ao modo de interação instaurado, não como contraponto à noção de paixão, mas como um dos componentes do processo de configuração desta última, no qual o sentir age como instância de medida das tensões no campo de presença, permitindo a identificação de um "estilo semiótico da afetividade", um "estilo tensivo da interação", próprio ao esquema do acontecimento, ou da implicação.

Como explica Fontanille (2007, p. 80), “os elementos naturais são visados e apreendidos por meio da energia que manifestam e do desdobramento espaçotemporal que são capazes de realizar". O "valor do valor", chave da relação intersubjetiva, é, portanto, definido pela posição no espaço de correlação das valências de intensidade (tonicidade e andamento) e das de extensidade (espaço e tempo), responsáveis pela resultante afetiva. Nos discursos, a dinâmica figural patemiza o figurativo e transforma os valores semânticos apresentados, enquanto produtos do uso, em valores afetivos, produtos da interação.

De acordo com Fontanille e Zilberberg (2001, p. 52), “[...] a valência apresenta-se como elemento analítico do valor, e, de maneira mais corrente, como o 'valor do valor' ". Ainda segundo os autores citados, os valores figurais (do plano da expressão e do plano de conteúdo, definidos em termos de intensidade e extensidade), ao serem convertidos em valores figurativos (do plano do conteúdo, resultantes da apreensão proprioceptiva do sujeito da percepção), dão origem a duas ordens de regimes axiológicos: os valores de absoluto, provenientes de um ponto de vista tímico por parte do sujeito da percepção convocado, sobretudo, em sua sensibilidade; e os valores de universo, típicos ao ponto de vista cognitivo assumido pelo actante sujeito incitado majoritariamente em sua inteligibilidade. Os primeiros marcam a exclusividade da presença no campo de tensão e delineiam uma interação da ordem da triagem axiológica; há um só acento de sentido, um só pólo de atração e convocação da percepção do sujeito. Os segundos, por sua vez, assinalam a distribuição da presença no tempo-espaço que configura o campo, e a interação será, portanto, da ordem da mistura axiológica, com um acento de 
sentido difuso, com mais de um polo de convocação sensível e inteligível.

Ao conceber a interação dessa maneira, a noção de junção permanece no centro do estudo das paixões, mas não enquanto relação de possessão entre sujeito e objeto-valor, na qual o primeiro é sempre ativo e o segundo passivo, e sim como interação perceptiva, com posições intercambiáveis que definem graus de transitividade, de densidade de presença, de gradação interativa do liame intersubjetivo. Isso é importante porque, como assinala Mancini (2007, p. 15):

Sabemos que toda a semiótica greimasiana é formulada com base na relação juntiva. Do trabalho de Propp à formulação de uma sintaxe narrativa, assim como no estudo dedicado às paixões envolvendo as precondições de formação do sentido -, a noção de junção está no centro das formulações semióticas. Mesmo uma aproximação mais decidida da teoria com suas bases fenomenológicas não alterou tal fato. Os avanços propostos pelos seguidores de Greimas, pautados pela coerência teórica, mantiveram a primazia da junção, cujo papel estruturador se mantém intacto seja no conceito de campo de presença, introduzido com os estudos sobre a tensividade, seja nas discussões subsequentes sobre o corpo.

Perceber o outro, as coisas, o mundo de um modo geral, seria, pois, interagir com eles, estabelecer um vínculo de "mão dupla", no qual o sujeito age sobre o objeto percebido e impõe-lhe representações impressivas, cria simulacros, sofrendo, ao mesmo tempo, a sua ação, ao reagir, de forma sensível e inteligível, a ele, ao valor nele investido, por ele representado. A própria definição corrente do termo interação, registrada pelos dicionários de língua portuguesa, ao ressaltar o caráter de influência recíproca, fundamenta esse ponto de vista.

Segundo o verbete do Houaiss, interação diz respeito à:

s.f. (sXX) 1 influência mútua de órgãos ou organismos interrelacionados; ação mútua ou compartilhada entre dois ou mais corpos ou indivíduos [...]; 2 comunicação entre pessoas que convivem; diálogo, trato, contato; [...] 5 SOC conjunto das ações e. relações entre os membros de um grupo ou entre grupos de uma comunidade. [...] • ETIM inter- + ação • PAR inteiração (s.f.) (HOUAISS, 2009, p. 1095, grifo nosso)

Interagir é, portanto, participar de uma "ação mútua", uma co-presença 
entre interactantes. A existência semiótica, a transmissão de valores e a própria composição do "valor do valor" por parte do sujeito perceptivo, estariam, nesse caso, fundamentadas, antes de mais nada, no ato de percepção, na tensão que liga o sujeito ao objeto e configura um campo de coexistência, a partir do qual emerge a interação (perceptiva). De qualquer maneira, conforme bem aponta Fontanille (2007, p. 242):

\begin{abstract}
Afirmar que a significação se apoia na percepção e que o inteligível é indissociável do sensível, é apenas uma mera petição de princípio ou, ainda, uma posição filosófica, enquanto não examinamos como a conversão ocorre concretamente no discurso. No entanto, agora nós temos os meios para fazê-lo: a estrutura tensiva, a semiótica da presença e a apreensão impressiva nos dão acesso, do ponto de vista do método, a esse tipo de "advento" semiótico. Contudo, precisamos também nos perguntar o que buscamos descobrir com isso: a esse respeito, a questão poderia ser aquela da especificidade semiótica dos modos sensoriais.
\end{abstract}

Parafrasearíamos esse último trecho do autor, para dizer que a esse respeito, a questão poderia ser a da "especificidade semiótica dos modos de interação afetiva". Vale lembrar, no entanto, que os modos de interação entre sujeito da percepção e objeto percebido - mais sensíveis ou mais inteligíveis -, embora já tragam à cena uma forma de afetividade, estão em um nível bastante geral e de grande abstração, o que os torna amplos demais para a análise de estados de alma próprios a um tipo de interação mais complexa no qual, para além das determinações tensivas que a dinamizam, atuam também outros quesitos.

Nesse sentido, pensando não em uma oposição paradigmática, mas em níveis de pertinência de relação integrativa, que caminharia de uma micro a uma macro-sintaxe passional, propomos falar em modos primários de interação afetiva e em modos complexos de interação afetiva. Os primeiros responderão pelos efeitos de sentido patêmicos resultantes da interação do sujeito da percepção com seus entornos, com as grandezas que se apresentam em seu campo perceptivo e se transformam em presença; e os segundos, pelas paixões englobantes, próprias a um tipo específico de interação com um objeto-valor também peculiar, a partir do qual, para além de uma reação passional mais pontual, o que se tem é de fato um estado de alma. 


\subsubsection{Modos primários e modos complexos de interação afetiva}

Podemos dizer que a diferença entre os modos primários (micro-sintaxe passional) e os modos complexos de interação afetiva (macro-sintaxe passional) diz respeito a uma complexificação sintáxica, e também semântica, de um para outro, uma vez que, no caso destes últimos, o que está em causa não é a simples interação entre um sujeito da percepção e o mundo percebido, mas, como dissemos, um tipo específico de interação perceptiva, pressupondo, da mesma forma, um objeto-valor próprio, um objeto-valor da paixão, porque a ele a afetividade resultante é dirigida.

Os modos primários de interação afetiva respondem, então, pelas reações patêmicas elementares, pelos efeitos de sentido passionais que, caracterizados apenas em termos de euforia e disforia, de convocação dominantemente sensível ou inteligível, e independentes de uma relação de intencionalidade mais específica, podem combinar-se dentro de uma interação afetiva complexa englobante, um estado de alma que toma o sujeito por inteiro, mobilizando-o afetivamente. Do domínio da predicação tensiva do campo de presença, em termos de intensidade e extensidade, eles dizem respeito à sensibilização do sujeito da percepção, à configuração de sua competência para sentir, isto é, de sua competência passional. As condições de configuração do campo de coexistência, próprias às modulações tensivas - predicação intensiva (tensão tônico / átono) e extensiva (tensão aberto / fechado, amplo / concentrado) -, ao determinar a densidade de presença dos interactantes, basta à compreensão do tipo de interação instaurado, mais da ordem do sensível, ou mais da ordem do inteligível, tal como propusemos anteriormente.

Já nos modos complexos de interação afetiva, o tipo de junção subjacente à relação interactancial instituída depende sobretudo da maneira pela qual se constitui, no campo tensivo, a presença do objeto-valor ao qual a afetividade resultante da interação se direciona. A sensibilização própria a um estado de alma tem, dessa forma, além da predicação tensiva que a dinamiza, advinda das condições de percepção fundantes da inter-relação, responsáveis pela convocação do sensível e do inteligível, outras determinações, desta vez, não só de ordem tensiva, mas também discursiva, associando as vicissitudes da captura, da 
convocação (sensível-inteligível) do sujeito da percepção, aos avatares da intencionalidade, do ato que o orienta a um objeto-valor específico.

Trata-se do semantismo construído, no nível discursivo, pela figurativização das grandezas que emergem no campo perceptivo do sujeito e delineiam, para o objeto-valor da afetividade suscitada, um modo de presença. Ou seja, as grandezas com as quais o sujeito da percepção interage no campo de presença podem, a partir do investimento figurativo que recebem no nível discursivo: (i) constituir-se, a partir de uma triagem axiológica, já enquanto objeto-valor da afetividade instaurada, firmando, pois, uma interação direta, porque não mediada, e, por isso mesmo, mais tônica, ou (ii) remeter a ele de maneira indireta e até difusa, porque através de uma mistura axiológica, na qual o valor investido no entorno mescla-se àquele do objeto-valor da afetividade, enfraquecendo, por isso mesmo, o liame interactancial.

$\mathrm{Na}$ primeira possibilidade, a exclusividade no campo da coexistência interactancial faz o objeto-valor da afetividade ter alta densidade de presença uma vez que o seu desenvolvimento figurativo, no nível discursivo, apresenta-se como inflexão de tonicidade ao valor nele investido -, o que dá origem a uma junção, ou melhor, a um estado de alma de ordem dominantemente sensível, estésico, correlacionado aos valores de absoluto, típicos a um ponto de vista mais individualizado por parte do sujeito da percepção no momento da interação.

Na segunda alternativa, a densidade de presença do objeto da paixão será menor, porque os valores neles investidos se distribuem na figuratividade e misturam-se às outras grandezas emergentes no campo tensivo, aos entornos, também axiologizados; o que provoca um devir e com ele a possibilidade de maior processamento inteligível da presença do objeto-valor da afetividade, próprio a um estado de alma de caráter mais cognitivo, dirigido predominantemente pelos valores de universo, a um ponto de vista mais generalizante.

De toda forma, tanto em um caso como no outro, trata-se apenas de uma lógica de regimes de dominância: o sensível prevalece em detrimento do inteligível ou vice-versa, uma vez que estamos defendendo exatamente a indissociabilidade das duas dimensões na configuração dos afetos. Seja com forte convocação estésica, 
ou fraca, nos dois casos há afetividade, há a mobilização, a "captura" do sujeito da percepção. 0 que varia é a natureza (qualitativa) da paixão desencadeada, o efeito proprioceptivo produzido sobre o corpo próprio do sujeito apaixonado, influindo diretamente no modo de interação afetiva instaurado, no modo de assimilação do valor investido no objeto da afetividade, de configuração do "valor do valor".

A predicação preponderante na configuração dos modos complexos de interação afetiva é, nesse sentido, a existencial (tensão presença / ausência). Segundo os autores de Tensão e significação (2001, p. 131), "as modulações da presença e da ausência fornecem, em suma, a primeira modalização das relações entre o sujeito e o objeto tensivos, a modalização existencial". Eles explicam (2001, p. 133):

[...] se erigimos a intensidade / extensidade como dimensões $a b$ quo, a apreensão da presença torna-se indissociável da avaliação dessa tonicidade: o simulacro semiótico, a própria semiose, resultaria, sob esse aspecto, de um compromisso entre as duas modulações extremas que são, por um lado, o excesso de presença do mundo natural (o "pleno" da expressão, a plenitude sensível das tensões) e, por outro, o excesso de ausência do mundo interior (o vazio de conteúdo, a ausência de articulações). Entre esses dois extremos, a significação se nutre de todos os graus de modulação recíproca da presença e da ausência.

É por isso que, embora a dinâmica interna seja muito parecida com a dos modos primários de interação afetiva, responsáveis pela convocação de tendência mais sensível ou mais inteligível do sujeito da percepção, não se pode perder de vista que, em um nível de pertinência superior, a natureza da relação interactancial (mais sensível ou mais inteligível) nos modos complexos de interação afetiva está relacionada não à interação com o valor investido no todo da presença que se constitui no campo perceptivo do sujeito e suscita reações impressivas, efeitos patêmicos, mas ao modo de presença dos valores que investem o objeto ao qual a afetividade então produzida se direciona. Em suma, os modos primários dizem respeito às reações patêmicas mais pontuais e gerais, enquanto os modos complexos, à afetividade dirigida a um objeto-valor específico, a uma interação afetiva na qual se estabelece de fato um vínculo entre o sujeito e objeto da paixão desencadeada. 
Como confirmam Fontanille e Zilberberg (2001, p. 157), "a abordagem das 'modalizações existenciais' continua ligada à intensidade e à extensidade, mas num nível de articulação diferente”. Afinal, conforme lembra Fontanille (2002a, p. 635 ${ }^{37}$ ), "a combinação de um grau de intensidade com um grau de extensidade determina, por sua vez, um grau de presença”. Assim, os dois modos de interação afetiva em questão não excluem um ao outro, mas, ao contrário, combinam-se e completamse, demonstrando o intrínseco cruzamento do figural com o figurativo na configuração dos estados de alma.

\subsubsection{Os modos complexos de interação afetiva: condições de configuração dos estados de alma}

Greimas e Fontanille, com o objetivo de fundar uma tipologia dos modos de existência a partir da categoria da junção, identificaram, em Semiótica das paixões (1993 [1991]), - em função do quadrado semiótico - para além do modo virtualizado, atualizado e realizado, já considerados pela teoria, também o potencializado, correspondentes, portanto, a não-conjunção, a disjunção, a conjunção e a não-disjunção, respectivamente. Anos mais tarde, em Tensão e Significação (2001 [1998], capítulo "Presença"), Fontanille e Zilberberg redistribuem a posição desses modos de existência no quadrado semiótico ${ }^{38}$ realizado, na posição de s1, como conjunção; virtualizado, na posição de s2, como disjunção; potencializado, na posição de ñs1, como não-conjunção; e atualizado, na posição de ñs2, como não-disjunção - e, associando-os agora à categoria da presença, apresentam-nos não mais como estados resultantes do decorrer das transformações narrativas, e sim enquanto provenientes da atividade perceptiva. Isso nos leva a pensar na possibilidade de adotar os diferentes modos de existência semiótica indicados (realização, virtualização, atualização e potencialização) como níveis epistemológicos de uma tipologia dos estados de alma, passíveis, pois, de

\footnotetext{
${ }^{37}$ Trecho original: “[...] la combinaison d'un degré d'intensité avec un degré d'étendue détermine donc un degré de présence."

${ }^{38}$ Para maiores detalhes sobre o "percurso de desenvolvimento" da noção de modos de existência, consultar Coelho (2007, p. 5-67).
} 
recobrir, ou melhor, de denominar os principais processos de articulação das dimensões envolvidas no momento da interação como em uma sintaxe elementar. Ou seja, propomos classificar os modos complexos de interação afetiva, para tornar mais operatória a sua análise, a partir da perspectivação da presença e da ausência do objeto-valor da afetividade no campo tensivo, da modulação dos seus graus de presença e de sua tonicidade perceptiva; isso porque eles "organizam o campo perceptivo e, transitando através do percurso gerativo, condicionam a própria semiose discursiva" (FONTANILLE; ZILBERBERG, 2001, p. 133).

Essa nossa ideia dialoga com aquela sugerida por Fontanille no artigo de 1995b, "La base perceptive de la sémiotique", quando ele fala no estabelecimento de quatro estados de alma fundamentais - "presentificação" da presença; "ausentificação" da ausência; "presentificação" da ausência; "ausentificação" da presença - resultantes das diversas possibilidades de modulação da presença e da ausência; e relaciona-se também com as proposições feitas por ele no capítulo “Passions et émotions", de Sémiotique et littérature (1999), no qual é apresentada a ideia de paixões da presença, advindas do modo como o sujeito passional experimenta os diferentes graus da presença ${ }^{39}$.

Os modos de existência da significação (questão mais ampla da epistemologia), caracterizados pela densidade de presença procedente da relação fórico-tensiva entre sujeito e objeto, irão tornar-se, nessa perspectiva, modos de existência dos estados de alma; isto é, eles funcionarão como modalidades das interações patêmicas complexas (questão de método e análise). Ao associar a categoria juntiva à da presença, desta vez, do objeto-valor da afetividade, e ao fixála nos modos de existência correspondentes, o que estamos sugerindo é a determinação de quatro modos complexos de interação afetiva de base - fusão, cisão, aproximação e desprendimento - que teriam, tal como foi apresentado em Tensão e significação (2001), a seguinte distribuição no quadrado semiótico (cf. Esquema 1.1):

\footnotetext{
${ }^{39}$ Essa mesma proposição foi retomada no artigo "Sémiotique des passions" (FONTANILLE, 2002a, p. 601-637).
} 


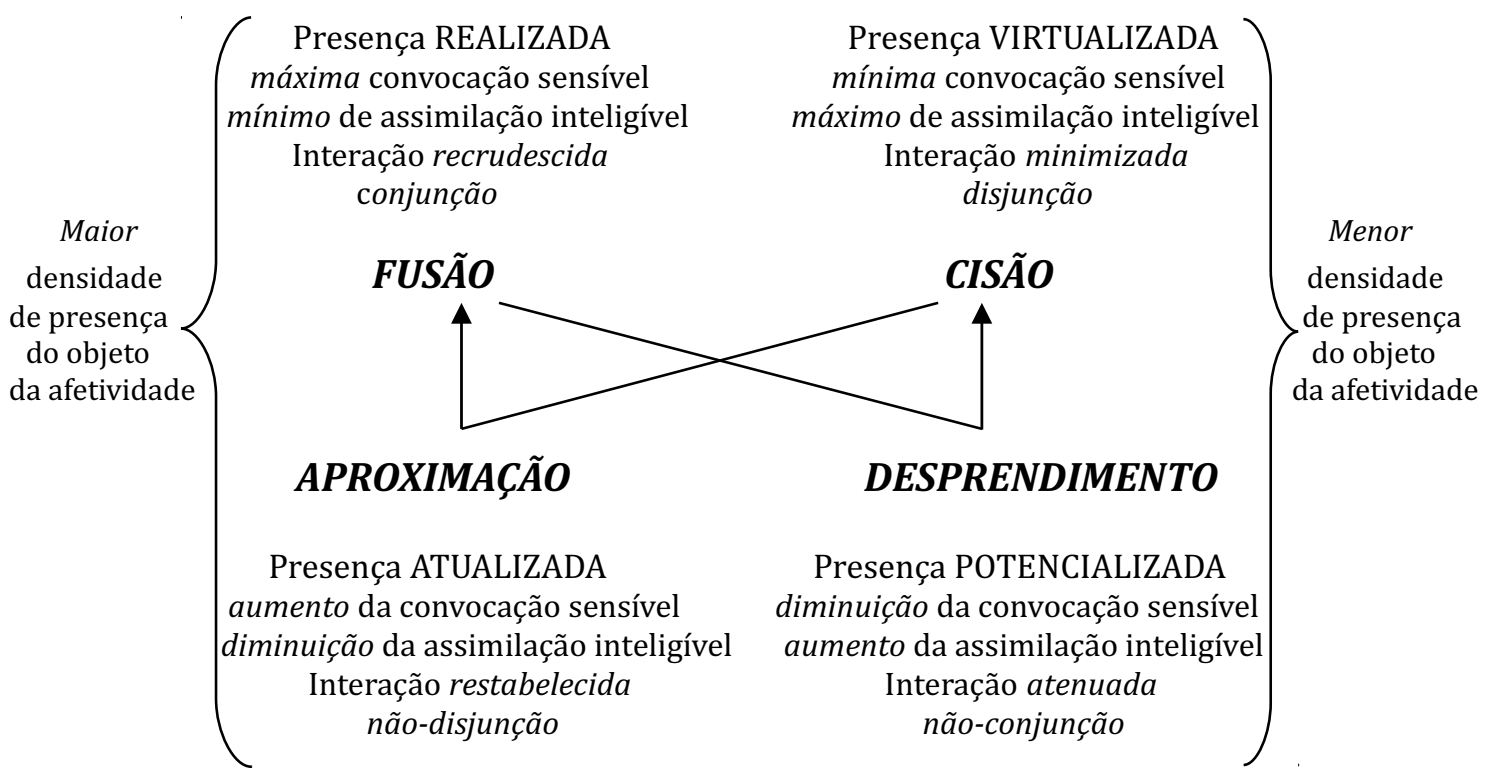

Esquema 1.1: Proposição de um quadrado semiótico dos modos complexos de interação afetiva de base (elaboração nossa a partir do quadrado semiótico sugerido por Fontanille e Zilberberg, 2001).

Independente dos nomes adotados para categorizar os modos complexos de interação afetiva de base, uma vez que "nomear" processos é sempre a parte mais crítica, e frágil, de uma proposta científica, o importante é a estabilização das especificidades sintáxicas dos processos subjacentes responsáveis pela sua instauração; ou seja, a relevância não está no nome dos termos apresentados, mas sim nas peculiaridades do devir da correlação tensiva e afetiva que eles caracterizam. Afinal, conforme lembra Greimas (1983, p. $17^{40}$ ), "a reflexão teórica, por menor que seja sua fecundidade, carrega o inconveniente de quase sempre ultrapassar os conceitos que ela forja e os termos que escolhe para designá-los."

Assim, nos polos extremos:

- um estado de alma da ordem da conjunção, que tem o efeito de fusão entre o sujeito da percepção e o objeto-valor da afetividade, pressupõe o máximo de densidade de presença e tonicidade perceptiva deste último, instituídas a partir da exclusividade no campo de presença, própria a uma presença viva,

\footnotetext{
${ }^{40}$ Trecho original: "La réflexion théorique, pour peu qu'elle soit féconde, comporte l'inconvénient de
} dépasser presque toujours les concepts qu'elle se forge et les termes qu'elle choisit pour les désigner." 
recrudescida, com a qual se estabelece uma interação afetiva direta, sem mediações, e, por isso mesmo, mais impactante;

- um estado de alma da ordem da disjunção, típica ao efeito de cisão interactancial, resulta da escassez da presença, da quase nãopercepção do objeto-valor, que, com tonicidade perceptiva mínima, suscita baixa convocação sensível, fazendo atuar em dominância, na sua assimilação, o inteligível.

No que diz respeito às resultantes intermediárias:

- um estado de alma da ordem da não-conjunção, cujo efeito da relação interactancial é o de desprendimento, assinala uma atenuação, uma perda da densidade existencial da presença diluída do objeto-valor da afetividade no campo tensivo, evidenciando a diminuição da tonicidade perceptiva e com ela o grau de convocação sensível, o que, por outro lado, permite o aumento da atuação do inteligível na interação afetiva instituída;

- em um estado de alma da ordem da não-disjunção, característico à relação interactancial fundada no efeito de aproximação, haverá um ganho, um restabelecimento da convocação sensível e uma diminuição da ação do inteligível do sujeito perceptivo, proveniente de um aumento da densidade de presença e, consequentemente, da tonicidade perceptiva do objeto-valor da afetividade no campo tensivo, fundando a interação patêmica.

Serão, pois, os modos de presença do objeto-valor da afetividade no campo de co-existência interactancial, em sua relação com os entornos, os responsáveis pela determinação do grau de afetividade configurado, advinda de uma convocação dominantemente sensível, ou inteligível, conforme prevaleça um maior ou menor 
grau de tonicidade perceptiva do objeto-valor ao qual a passionalidade suscitada se dirige. Em cada caso, o afeto resultante do modo de interação estabelecido estará clivado nas duas categorias elementares da sintaxe passional - o sujeito da percepção e o objeto-valor da afetividade -, entre as quais a tensão emocional, no campo de presença, pode evoluir, em um movimento descendente, da contração máxima, que é a realizante da relação interactancial, por fusão, até o seu contrário, a contração mínima (distensão máxima), que virtualiza a interação; ou vice-versa, assinalando um movimento ascendente da tensividade. Em cada uma das circunstâncias, a composição (figurativa) do entorno percebido, bem como os valores que dele emergem, serão o fator de coesão ou dispersão da tensão interactancial.

Ademais, as duas possibilidades de relação sintagmática - entre os modos de interação afetiva de base - que deixa entrever o quadrado semiótico, orientadas seja em um percurso ascendente da tensão (interação passional virtualizada $\rightarrow$ atualizada $\rightarrow$ realizada) seja em um descendente (interação afetiva realizada $\rightarrow$ potencializada $\rightarrow$ virtualizada), traz à cena uma outra possibilidade de classificação dos modos complexos de interação afetiva, mais geral, uma "arquicategoria" que os dividiria em dois grupos: o das paixões de conjunção e o das paixões de disjunção. Assim, os estados de alma próprios aos modos de interação da dêixis dita "positiva" (fusão, aproximação) correspondem às paixões procedentes de um modo de conjunção afetiva (interação realizada, ou atualizada); aqueles da dêixis "negativa" (cisão, desprendimento), às paixões típicas a um modo de disjunção afetiva (interação virtualizada, ou potencializada).

De toda forma, o quadrado, mesmo ao definir os deslocamentos possíveis entre os modos complexos de interação afetiva (interpretação sintagmática), concebido em posições discretas, como estados de alma fixos, salienta sobretudo as relações de oposição entre um modo de existência das interações afetivas e outro (interpretação paradigmática). A noção de gradualidade da interação patêmica, resultante do modo de articulação, no momento da percepção, da convocação sensível com a assimilação inteligível da presença do objeto-valor da afetividade, fica, então, prejudicada. 
Isso nos leva a pensar na possibilidade de uma categorização de orientação progressiva e contínua dos modos de existência da interação afetiva, dos estados de alma, que, além de ser mais adequada ao que temos formulado e à concepção de graus de interatividade, graus de articulação do sensível com o inteligível, permite o exame de paixões que não se encaixariam, exatamente, em nenhum dos modos complexos de base, mas penderiam mais para um ou mais para outro, paixões que estariam entre um modo de interação afetiva e outro. Segundo Zilberberg (2001, p. $95^{41}$ ), “o conceito de medida comporta um sincretismo interessante: a medida é, sobretudo, a medida de um intervalo [...]".

Essa ideia está próxima àquela apresentada por Luiz Tatit em alguns de seus trabalhos e que diz respeito à noção de quantificação subjetiva, na qual mais mais, mais menos, menos mais e menos menos funcionam como "unidades de medida" da afetividade. Segundo o autor (2011, p. 49):

As quantificações subjetivas estão implícitas nas escolhas epistemológicas da teoria semiótica. 0 quadrado greimasiano, em quase todas as versões, articula a oposição entre mais mais e mais menos, passando até mesmo por uma fase de negação ou diminuição dos extremos (menos mais e menos menos).

A "medida subjetiva" da interação, calcada na densidade de presença instaurada na relação perceptiva entre os interactantes, caracteriza, pois, o grau de afetividade da ligação entre eles como resultado de um movimento orientado a partir da correlação entre a intensidade e a extensidade da presença do objetovalor da afetividade, entre a convocação sensível e a assimilação inteligível, com as posições - os modos de existência da interação afetiva, dos estados de alma - sendo fixadas na zona comedida pelo distanciamento adquirido dos pontos extremos mais e menos: quanto mais densidade de presença do objeto-valor ao qual o afeto é direcionado, maior convocação estésica do sujeito perceptivo e, consequentemente, maior o grau de afetividade da interação; quanto menos, menor o liame patêmico interactancial e maior a possibilidade de uma assimilação inteligível da presença, como buscamos demonstrar nos gráficos propostos (cf. Esquemas 1.2 e 1.3):

\footnotetext{
${ }^{41}$ Trecho original: "Le concept de mesure comporte un syncrétisme intéressant: la mesure est d'abord mesure d'un intervalle [...]"
} 


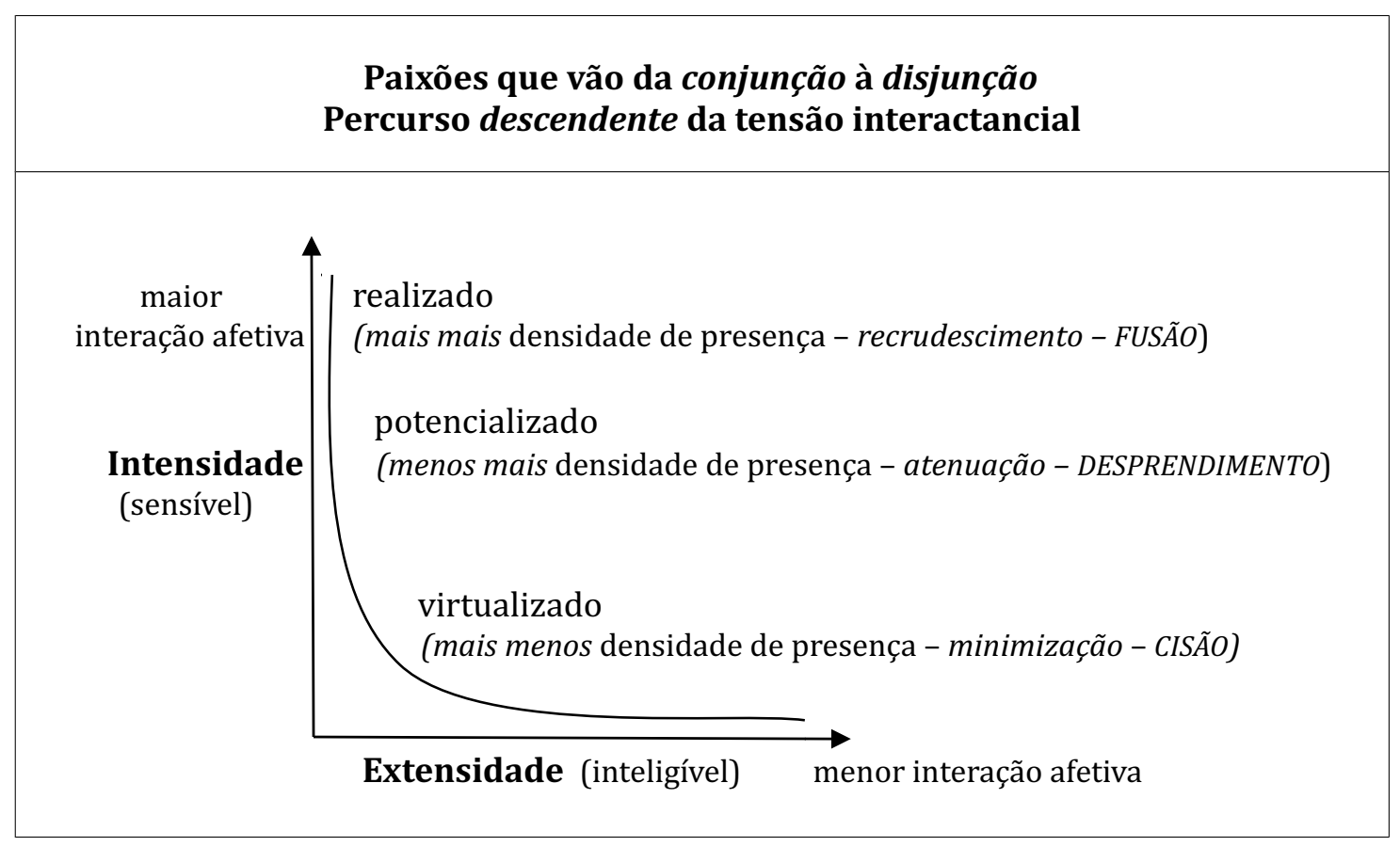

Esquema 1.2: Gráfico tensivo do percurso descendente da tensão interactancial (elaboração nossa a partir do gráfico tensivo de correlação inversa proposto por Zilberberg em seus trabalhos).

\begin{tabular}{|c|c|}
\hline $\begin{array}{c}\text { Paixões que vão da disjunção à conjunção } \\
\text { Percurso ascendente da tensão interactancial }\end{array}$ \\
\hline $\begin{array}{c}\text { Intensidader } \\
\text { (sensível) }\end{array}$ & $\begin{array}{l}\text { realizado } \\
\text { (mais mais densidade de presença - recrudescimento - FUSÃO) }\end{array}$ \\
$\begin{array}{l}\text { (menos menos densidade de presença - restabelecimento - APROXIMAÇÃO) } \\
\text { virtualizado } \\
\text { (mais menos densidade de presença - minimização - CISÃO) }\end{array}$ \\
Extensidade (inteligível) \\
menor interação afetiva
\end{tabular}

Esquema 1.3: Gráfico tensivo do percurso ascendente da tensão interactancial (elaboração nossa a partir do gráfico tensivo de correlação inversa proposto por Zilberberg em seus trabalhos). 
Pode haver também uma correlação conversa entre intensidade e extensidade, com essas duas dimensões caminhando juntas, na mesma proporção; contudo, como assinalado anteriormente, acreditamos que essa forma de articulação, ao preservar os extremos (mais e menos), pode neutralizar os efeitos patêmicos. Por isso, adotamos a correlação inversa como a configuração sintáxica mais pertinente à análise das interações afetivas.

Em consonância com o princípio ressaltado por Zilberberg (2011, p. 101) a propósito da sintaxe intensiva, no qual ele explica que, no campo de presença, "um aumento tem por objeto interno uma diminuição e de igual modo uma diminuição tem por objeto interno um aumento", o modo de interação afetiva complexo realizado, próprio à fusão dos interactantes, corresponde ao ápice, ao máximo de tonicidade perceptiva, de densidade de presença do objeto-valor da afetividade no espaço tensivo de coexistência, e define, por conseguinte, um maior grau de convocação sensível e menor de convocação inteligível; o modo de interação afetiva complexo potencializado, que, em um movimento descendente, incita o desprendimento do sujeito pelo objeto-valor, diz respeito, então, a um grau menor de convocação sensível e um grau maior de convocação inteligível; o modo de interação afetiva complexo virtualizado, por sua vez, manifestando a cisão do sujeito para com o objeto-valor, representa a fraca densidade de presença deste último, minimizada, quase se extinguindo; daí o mínimo de convocação sensível e o máximo de atuação do inteligível; e o modo de interação afetiva complexo atualizado, em um movimento de ascendência, restabelece a tonicidade perceptiva, e desperta a aproximação do sujeito da percepção em relação à presença, dado o aumento da convocação sensível e a diminuição da atividade inteligível.

Essa distinção gradualizada do modo de convocação do sujeito da percepção, podendo, pois, ser "medida", é importante, por exemplo, para a análise de afetos vizinhos, nos quais a diferença provém da força da tensão emocional em causa, diretamente relacionada, acreditamos, ao grau de passionalidade envolvido, ao modo como sensível e inteligível se articulam no processo de configuração da interação perceptiva - como procuraremos demonstrar ser o caso da compaixão e da piedade. Além disso, tal abordagem, justamente por estar fundada nas 
(pré-)condições (sintáxicas) de emergência da interação passional a partir da percepção, no devir da afetividade, no modo de convocação do sensível e do inteligível, apresenta-se, portanto, como uma sintaxe elementar dos modos complexos de interação afetiva, o que possibilita o estabelecimento de uma tipologia das paixões aquém do relativismo cultural, dos investimentos semânticos e da nomeação daí decorrente, do seu reconhecimento como paixão ou não em uma dada cultura.

Os quatro modos complexos de interação afetiva de base propostos (fusão, cisão, aproximação e desprendimento) funcionariam, dessa forma, como quatro grandes classes predicativas nas quais os afetos reconhecidos e nomeados em determinada sociedade se inscreveriam. A relevância de uma classificação desse tipo está no seu caráter abstrato de possível generalização que permite mesmo a análise de "paixões sem nome", dos estados patêmicos experimentados por um sujeito, mas ainda não fixados culturalmente. Afinal, como assinalam Fontanille e Zilberberg (2001, p. 299), "assim que uma paixão é identificada e denominada, não estamos mais na ordem da dimensão passional viva, mas na dos estereótipos culturais da afetividade".

\subsubsection{Percurso da análise: uma interpretação tensiva do esquema passional canônico}

Uma vez definida a tipologia dos modos complexos de interação afetiva passível, esperamos, de dar conta da classificação tanto dos fenômenos passionais ainda não nomeados quanto dos já lexicalizados e cristalizados pelo uso de determinada cultura -, o próximo passo é oferecer um percurso de análise da interação em ato, capaz de depreender nela não só as determinações sintáxicas já elencadas, mas também o modo de articulação e de estruturação dessas premissas no processo de configuração do "valor do valor" que faz emergir dada paixão.

Greimas e Fontanille, a partir dos estudos realizados em Semiótica das paixões (1993), procurando instituir uma coerência formal ao percurso passional do sujeito apaixonado, fixaram, a exemplo do tradicional esquema narrativo 
canônico [manipulação - competência - performance - sanção], o esquema passional canônico [constituição - sensibilização (disposição - patemização emoção) - moralização], considerado, tal como o primeiro, um modelo autônomo e dotado de um valor heurístico próprio.

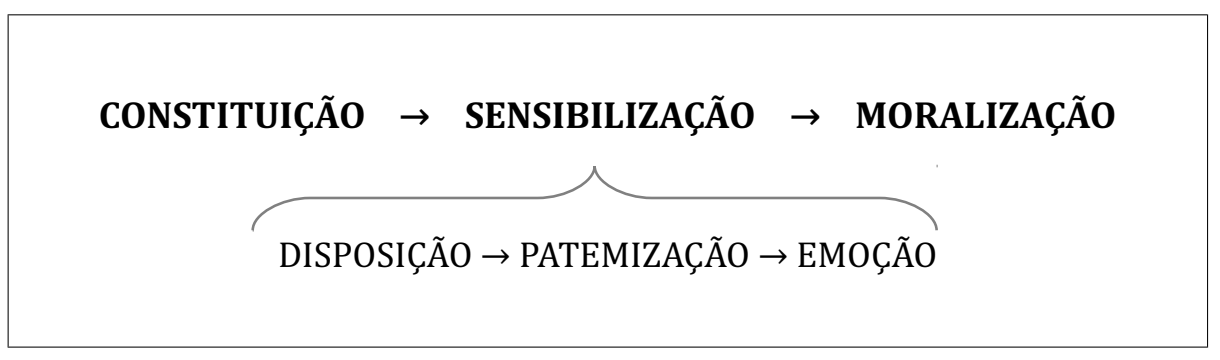

Esquema 1.4: Esquema passional canônico sugerido em Semiótica das paixões (GREIMAS; FONTANILLE, 1993).

A ideia era o estabelecimento de um modelo de análise "concebido e construído como estrutura generalizável" (GREIMAS; FONTANILLE, 1993, p. 61), isento, na medida do possível, do relativismo cultural, permitindo que as configurações passionais dos discursos pudessem ser identificadas e descritas independentemente de sua lexicalização. Assim, a estratégia de concepção do esquema é a de fases agenciadas progressivamente, ordenando de maneira dedutiva e calculável o desenvolvimento do percurso patêmico que afeta o sujeito narrativo.

A constituição, a sensibilização e a moralização foram, pois, reconhecidas como as três principais formas de construção dos universos passionais que controlam as culturas individuais e as coletivas. Segundo os autores (1993, p. 244 / 245), "esses três segmentos comportam, no esquema patêmico canônico, referências às axiologias passionais, e, mais particularmente, àquelas que asseguram a regulação das relações sociais interindividuais". Eles acrescentam (Idem, p. 245): "[os três segmentos] convocam para isso grades idioletais e socioletais de representação da paixão, de suas causas, de seus efeitos, de seus critérios de identificação e de avaliação". Dentro desse quadro, a disposição, a patemização e a emoção correspondem às etapas sucessivas do processo passional propriamente dito (sensibilização), do momento juntivo que marca a relação entre 
o sujeito e o seu objeto tímico.

Dois anos após a publicação original de Sémiotique des passions (1991), Fontanille, em um artigo intitulado "Le schéma des passions", de 1993b - revista Protée, volume 21, número 1 -, apresenta o que ele chama de "uma reformulação, explicação e ilustração das proposições feitas hipoteticamente sobre este assunto em Semiótica das paixões" (p. $33^{42}$ ). Nesse texto, ao contrário do que foi apresentado na primeira vez, o semioticista busca não apenas elucidar as etapas do modelo (agora esquematizado sem subdivisões: constituição - disposição patemização - emoção - moralização), mas também incluir um ponto de vista mais próximo à noção de tensividade, cujo valor operatório é discutido na Introdução que antecede os capítulos de análise do livro escrito em parceria com Greimas.

De acordo com o autor (1993b, p. $33^{43}$ ), "o esquema patêmico proposto em Semiótica das paixões resulta, no plano epistemológico, tanto de uma generalização, a partir de um conjunto de considerações práticas, quanto de uma extrapolação do esquema narrativo canônico". Mas ele adverte (p. $34^{44}$ ):

[...] o método que dirige a elaboração dos dois esquemas é muito diferente: o ENC [esquema narrativo canônico] resulta da 'bricolage', da redução de um conjunto de 'funções' proppianas e de noções emprestadas da linguística chomskiana, bricolagem e redução com o intuito de integrar mutuamente a reflexão sobre a lógica narrativa e a reflexão sobre os diversos modos de existência dos fatos linguísticos; [...] o EPC [esquema passional canônico] resulta de um tateamento, de uma elaboração progressiva motivada por um único objetivo: detalhar as operações constitutivas do processo passional, a partir das primeiras análises concretas realizadas sobre essa questão durante toda uma década, dando-lhes, de maneira homogênea, nomes de

\footnotetext{
${ }^{42}$ Trecho original: "Cette présentation du schéma pathémique canonique se présente tout d'abord comme une reformulation, une explication et une illustration des propositions faites sur ce sujet, à titre d'hypothèse, dans Sémiotique des passions."

${ }^{43}$ Trecho original: "Le schéma pathémique proposé dans Sémiotique des passions résulte, au plan méthodologique, à la fois d'une généralisation à partir d'un ensemble de considérations pratiques, et d'une extrapolation à partir du schéma narratif canonique."

${ }^{44}$ Trecho original: "[...] la méthode qui a présidé à l'élaboration des deux schémas est très différente: le SNC résulte du 'bricolage' et de la réduction d'un ensemble de 'fonctions' proppiennes et de notions empruntées à la linguistique chomskienne, bricolage et réduction de nature à intégrer l'une à l'autre la réflexion sur la logique narrative et la réflexion sur les divers modes d'existence des faits linguistiques; [...] le SPC résulte d'un tâtonnement, d'une élaboration progressive motivée par un seul objectif: détailler les opérations constitutives du processus passionnel, à partir des premières analyses concrètes menées sur cette question pendant une dizaine d'années, et leur donner de manière homogène des noms d'opérations (d'où le suffixe 'tion')."
} 
operações (o que explica o sufixo "-ção").

De qualquer forma, com base no esquema narrativo, o esquema passional canônico - tanto em Semiótica das paixões, quando a tensividade ainda aparecia nas análises práticas de modo bastante tímido, quase somente em termos de aspectualização, quanto neste texto posterior de Fontanille, no qual o autor procura apresentá-la de forma mais evidente - acabou privilegiando não o exame e a descrição das peculiaridades sintáxicas da configuração patêmica em si, ou, como diz o próprio autor, "as operações constitutivas do processo passional", mas os diferentes estados passionais no percurso patêmico do sujeito apaixonado nos discursos.

As etapas da sequência estabelecida no esquema passional canônico definem, portanto, estágios de evolução do estado patêmico do sujeito, ou seja, identidades transitórias do sujeito discursivo no sintagma passional, papéis patêmicos que permitem a compreensão de seu estilo global, sua identidade afetiva a partir da junção; isso porque a ideia era representar "sob a forma de um esquema canônico os diversos modos de existência do sujeito apaixonado" (FONTANILLE, 1993b, p. $35^{45}$ ). Em função disso, a configuração propriamente dita do processo patêmico, as condições de emergência, de articulação do sensível com o inteligível na produção da afetividade, ficaram de fora, com as paixões sendo identificadas e descritas a partir de comportamentos estereotipados traduzidos em modalidades, sem a possibilidade de explicar também as modulações tensivas que fazem de tais combinações modais estruturas passionais, bem como as particularidades sintáxicas subjacentes aos patemas-processos concebidos como "conjunto das condições discursivas necessário à manifestação de uma paixão-efeito de sentido" (GREIMAS; FONTANILLE, 1993, p. 78).

Nessa primeira proposição do esquema passional canônico, Greimas e Fontanille (1993) definem a etapa da constituição como sendo um determinismo do sujeito: social, psicológico, hereditário, ou qualquer outro, mas sempre anterior a toda competência e disposição, típicas à instauração do sujeito apaixonado. Trata-

\footnotetext{
45 Trecho original: "[le SPC] traduit sous la forme d'un schéma canonique les divers modes
} d'existence du sujet passionné." 
se, como aparece na ocasião do estudo do ciúme, do momento em que é engendrado "o estilo tensivo do sujeito apaixonado" (GREIMAS; FONTANILLE, 1993, p. 243). É esta última concepção que defenderá Fontanille no artigo de 1993b, quando ele apresenta a constituição como a "etapa durante a qual o sujeito patêmico emerge no discurso [...] essencialmente por sua receptividade a todas as solicitações passionais procedentes de seu entorno" (p. $35^{46}$ ). Para o autor, nessa fase, agora reconhecida como sendo de modulações rítmicas (andamento) e quantitativas instáveis, o sujeito é apenas um sujeito que sente (FONTANILLE, 1993b).

A sensibilização e a moralização, pensadas em Semiótica das paixões como gestos culturais pelos quais determinada cultura "interpreta uma parte dos dispositivos modais, concebíveis dedutivamente, como efeitos de sentidos passionais" (GREIMAS; FONTANILLE, 1993, p. 140), são consideradas, em ambos os textos, como instâncias culturais de reconhecimento, articuladas de modo próprio à emergência discursiva da configuração patêmica propriamente dita, segundo os códigos identificáveis já firmados pelo uso.

0 estágio da sensibilização, articulado pelas fases da disposição, da patemização e da emoção, corresponde, dessa forma, à manifestação da paixão propriamente dita, passível de ser descrita, segundo coloca Fontanille (1993b), a partir (i) da articulação modal subjacente à identidade e à competência afetivas do sujeito, determinadas por sua relação com o objeto-valor (fase da disposição), (ii) da identificação de um comportamento estereotipado que, segundo as prescrições culturais, permite reconhecer e nomear o estado patêmico em questão (fase da patemização), e (iii) da expressão somática consequente (fase da emoção).

A propósito da moralização, como explicam Greimas e Fontanille (1993, p. 154), ela "intervém em fim de sequência e recai sobre o conjunto, mas mais particularmente no comportamento observável". É o momento da inserção da configuração passional no espaço de julgamento individual, ou coletivo, de certa comunidade. Em função do excesso, da insuficiência, ou da medida manifestados, a

\footnotetext{
${ }^{46}$ Trecho original: “La 'constitution' est l'étape pendant laquelle le sujet pathémique émerge dans le discours [...] essentiellement par sa réceptivité à toutes les sollicitations passionnelles issues de son environnement."
} 
paixão é, nessa etapa, moralizada por um observador social.

O esquema passional canônico, em sua primeira e segunda versão, apresenta-se, então, da seguinte maneira (cf. Esquema 1.5):

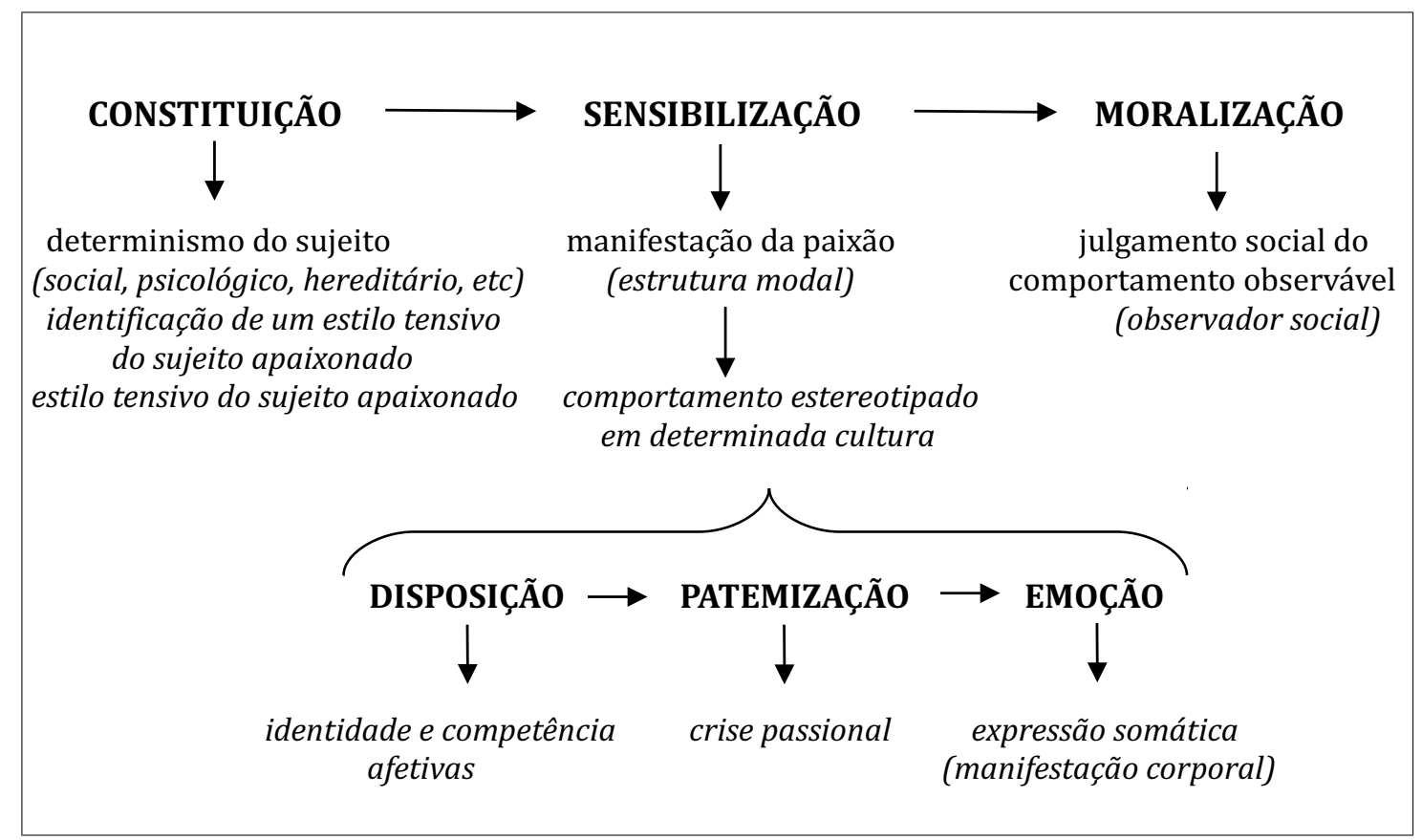

Esquema 1.5: Descrição das etapas do esquema passional canônico apresentado em Semiótica das paixões (GREIMAS; FONTANILLE, 1993).

Em suma, mesmo na reformulação proposta por Fontanille (1993b), o papel da tensividade na configuração dos afetos, tão discutido na introdução do livro que oficializa o surgimento de uma semiótica das paixões, continua restrito à fase da constituição, como pré-condição da instauração do núcleo patêmico, sem muitas indicações sobre a maneira pela qual ela pode ser depreendida nos discursos, e sobre sua influência na determinação das fases seguintes. As "operações" sintáxicas subjacentes, responsáveis pelo surgimento dos estados de alma, das modalidades que traduzem a interação e a junção do sujeito com seu objeto tímico, permanecem também ofuscadas por estágios patêmicos já manifestados. É só na "remodelagem" apresentada em Sémiotique du discours (1998; 2003, 2ª ed. ampliada), depois em Sémiotique et littérature (1999), e, anos mais tarde, no artigo "Sémiotique des passions", em Questions de sémiotique (HÉNAULT, 2002) - publicações, se não paralela, posteriores a Tension et signification, de 1998 -, que essas questões vão 
ser mais bem delineadas, passando da identificação de um percurso narrativo do sujeito apaixonado a uma sintaxe tensiva dos estados de alma.

Nessa terceira reformulação do esquema passional canônico, embora o número de fases tenha sido mantido, com troca apenas de alguns dos nomes (despertar afetivo - disposição - pivô passional - emoção - moralização), Fontanille (1999) propõe a projeção de uma estrutura e de uma variação tensivas subjacentes a todas as etapas da sequência, descritas agora em termos de intensidade e extensidade, de movimentos de ascendência e de descendência, nos quais está prevista a ideia de presença. Trata-se da perspectiva já lançada em Tensão $e$ significação (2001), no capítulo "Paixão", quando Fontanille e Zilberberg assinalam, a propósito da sintaxe da dimensão passional dos enunciados, a correlação entre a dimensão modal e a dimensão fórica, definidas em termos de constituintes (modais) e expoentes (tensivos), respectivamente.

Assim, a fase do despertar afetivo é entendida como o momento ascendente em que a sensibilidade do sujeito é despertada por uma presença caracterizada segundo sua intensidade e extensidade, que são, por sua vez, representadas por códigos rítmicos e aspectuais (expoentes tensivos). A disposição continua a ser considerada o estágio no qual "o sujeito recebe a identidade modal necessária para experimentar uma paixão ou um tipo de paixão e não uma outra" (FONTANILLE, 1999, p. $80^{47}$ ), como uma espécie de competência (modal) patêmica, classificada como descendente, por conta da colocação em cena de códigos modais (constituintes modais). 0 pivô passional também permanece como a principal etapa da sequência, na qual, através dos códigos figurativos, manifesta-se a paixão. Como explica Fontanille (2002a, p. 631 ${ }^{48}$ ), “essa fase é característica de um movimento de 'ascendência', pois ela põe em cena tanto um aumento da intensidade, quanto uma contração do campo de representações cognitivas, [...] na 'condensação' da extensidade e no 'deslocamento' (e a progressão) do acento de intensidade". Na emoção, manifestação corporal do sujeito afetado pelo impacto da fase anterior,

\footnotetext{
${ }^{47}$ Trecho original: “[...] le sujet reçoit l'identité modale nécessaire pour éprouver une passion ou un type de passion et pas un autre."

${ }^{48}$ Trecho original: "Cette phase est caractéristique d'un mouvement d' 'ascendance', car elle se développe à la fois par une augmentation de l'intensité et une contraction du champ des représentations cognitives [...] à la fois sur la 'condensation' de l'étendue et sur le 'déplacement' (et la croissance) de l'accent d'intensité."
} 
"são, novamente, os expoentes tensivos que ocupam o primeiro plano, sobretudo a intensidade, por meio dos códigos somáticos" (FONTANILLE, 1999, p. 81 ${ }^{49}$ ). A moralização, culturalmente determinada por seu caráter de avaliação e de "medida" das manifestações emocionais, do comportamento observável, é compreendida como uma fase de atenuação, de controle da paixão.

O esquema passional canônico passa, portanto, a se configurar do seguinte modo (cf. Esquema 1.6):

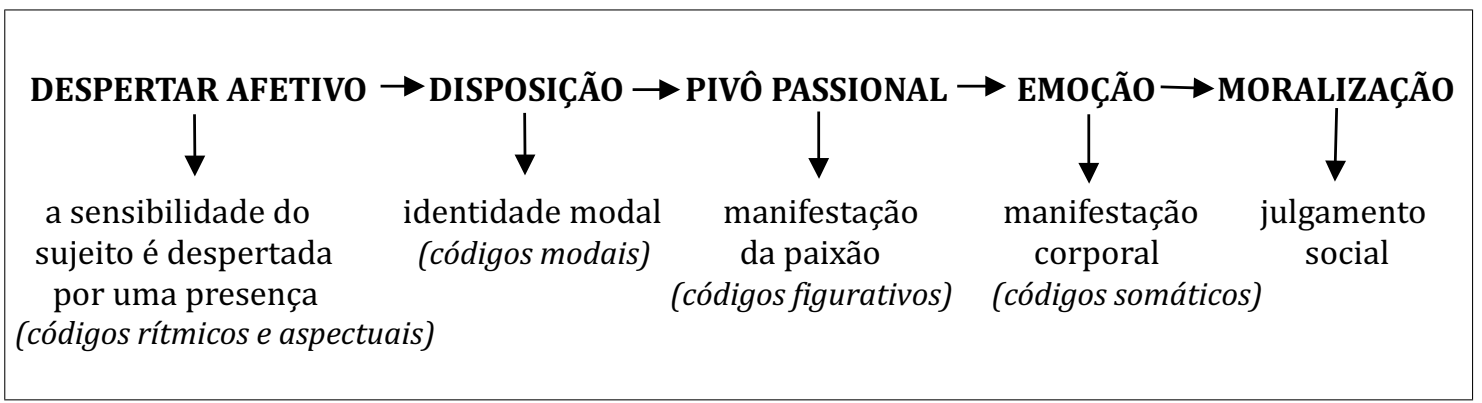

Esquema 1.6: Esquema passional canônico proposto por Jacques Fontanille (1999; 2000; 2002a).

Nesta última proposta do esquema, o exame das modulações tensivas é de fato trazido à cena, bem como as operações sintáxicas subjacentes aos patemasprocesso, isto é, ao "conjunto das condições discursivas necessário à manifestação de uma paixão-efeito de sentido" (GREIMAS; FONTANILLE, 1993, p. 78). No entanto, a nosso ver, mais do que as condições de emergência dos afetos na relação do sujeito com o objeto-valor, o modelo de análise continua a privilegiar a identificação e descrição de estados de alma já configurados, com a dimensão passional examinada no âmbito do uso, do discurso enunciado.

É por isso que, de nossa parte, ao adotar esse ponto de vista que entende a paixão como uma configuração cujas correlações, provenientes de diversos níveis do percurso gerativo, são ao mesmo tempo sensíveis e inteligíveis, propomos, como sugestão de atualização do esquema passional canônico, um modelo de análise fundamentado sobretudo nas especificidades de configuração da interação que faz emergir a paixão, o afeto, desta vez, na perspectiva da enunciação, do discurso em

\footnotetext{
${ }^{49}$ Trecho original: "Ce sont donc, à nouveau, les exposants tensifs qui reviennent au premier plan, notamment l'intensité, à travers les codes somatiques de l'émotion."
} 
ato, e não exatamente na identificação do percurso patêmico do sujeito no discurso enunciado, como foi feito até então. A ideia, tal como temos discutido desde o início, é a de apresentar um estudo das paixões, dentro do quadro epistemológico da semiótica discursiva, assentado nas noções de percepção e de presença, conforme as entende a linha tensiva da teoria.

Segundo assinala Fontanille (2007, p. 213), “a racionalidade passional consiste em conjugar gradientes perceptivos, gradientes da presença perceptiva em discurso", isso porque, "segundo a perspectiva da paixão, um processo não é considerado do ponto de vista de seu resultado, mas do ponto de vista de seu peso de presença” (Idem, p. 213). 0 estado juntivo que determina a interação passional entre o sujeito e o objeto-valor, a existência semiótica, será considerado, pois, conforme apresentamos anteriormente, como uma relação, antes de mais nada, perceptiva, na qual prevalece a problemática das modulações e do devir passional.

Buscaremos, desse modo, pensar as sequências do modelo proposto em Semiótica das paixões (1993) em um grau mais abstrato, com as modulações tensivas entendidas como propriedades elementares da percepção, como componentes do processo subjacente a determinado modo complexo de interação afetiva. Queremos com isso sugerir um percurso de análise capaz de dar conta das operações sintáxicas subjacentes à configuração das interações patêmicas, das suas condições de emergência, mostrando de que maneira os modos primários de interação afetiva, responsáveis pela produção da competência passional, integram a macro-sintaxe própria a determinado estado de alma.

A etapa da constituição passa, nessa nova interpretação do esquema, a ser considerada como a da instauração do campo de presença. É a fase na qual - a partir das primeiras somações resultantes da tensão criada na coexistência do sujeito e do "mundo natural" que se impõe a ele enquanto tensividade fórica - uma presença sensível se institui no campo de percepção do sujeito e dá origem à interação perceptiva.

Na sequência, a sensibilização responderia pelo processo de assimilação da presença, a articulação do sensível com o inteligível na produção da interação patêmica que liga sujeito perceptivo e objeto-valor percebido. É o estágio de 
categorização do sensível, de atuação da semiose. Agora é o sujeito que se impõe ao mundo enquanto ser dotado de linguagem.

Em sua subdivisão, a disposição seria, pois, o estabelecimento das determinações tensivas, das modulações intensivas e extensivas que determinam a profundidade do campo de presença instaurado. A patemização será, por sua vez, o segmento sensibilizador por excelência, o momento no qual, através da convocação sensível-inteligível do sujeito da percepção, os acentos fóricos (valores virtuais), convertem-se em valores axiológicos. É a etapa na qual se engendra a competência do sujeito da percepção para sentir, para vivenciar esta ou aquela paixão. A emoção virá, então, como consequência. Ela diz respeito ao grau de impacto da tensão apreendida, à reação somática manifestada (somação) diante do modo de presença do objeto-valor para o qual a afetividade suscitada é dirigida. Ela poderá ser tônica ou átona, forte ou fraca, a depender das determinações tensivas configuradas na etapa da disposição. É o estágio em que se define o estilo tensivo da interação patêmica, a natureza qualitativa do liame entre interactancial. Se a interação estiver sendo dirigida pelo sensível, o sujeito "perderá o controle" e se fundirá ao objeto-valor do afeto; mas, se ao contrário, for o inteligível a dimensão preponderante na assimilação da presença, o sujeito manterá o controle da emoção, que se tornará mais "inteligibilizada".

A moralização, ao agir no fim do percurso de configuração, equivaleria, nessa nova proposta de leitura do esquema passional canônico, à resolução, ao grau de intersubjetividade convocado, prescrevendo o modo de interação afetiva (fusão, desprendimento, cisão, aproximação) que define a paixão, passível, nesta fase, de ser traduzida em termos de modalidades, de combinatórias modais. Tratase da etapa na qual se consolida a conversão do valor axiológico apreendido em valor tímico, o "valor do valor", elemento central na configuração dos afetos. Quanto maior e mais forte for o impacto da presença do objeto-valor da afetividade, sentido pelo sujeito da percepção na etapa da emoção, mais tônica e sensível será a sanção intersubjetiva; por outro lado, quanto menor e mais fraca a presença, mais átona e inteligível a sanção se produzirá. A interação afetiva, na fase da moralização, tal como concebida nessa outra interpretação do esquema, 
configura-se para o próprio sujeito da percepção, independentemente da sanção de um observador social outro, que pode estar presente ou não, pode se dar conta ou não da relação intersubjetiva emergente. Trata-se, agora, da configuração da paixão para o próprio sujeito apaixonado e não mais a partir de um julgamento exterior do comportamento observável, conforme haviam formulado Greimas e Fontanille em Semiótica das paixões (1993).

Em resumo (cf. Esquema 1.7):

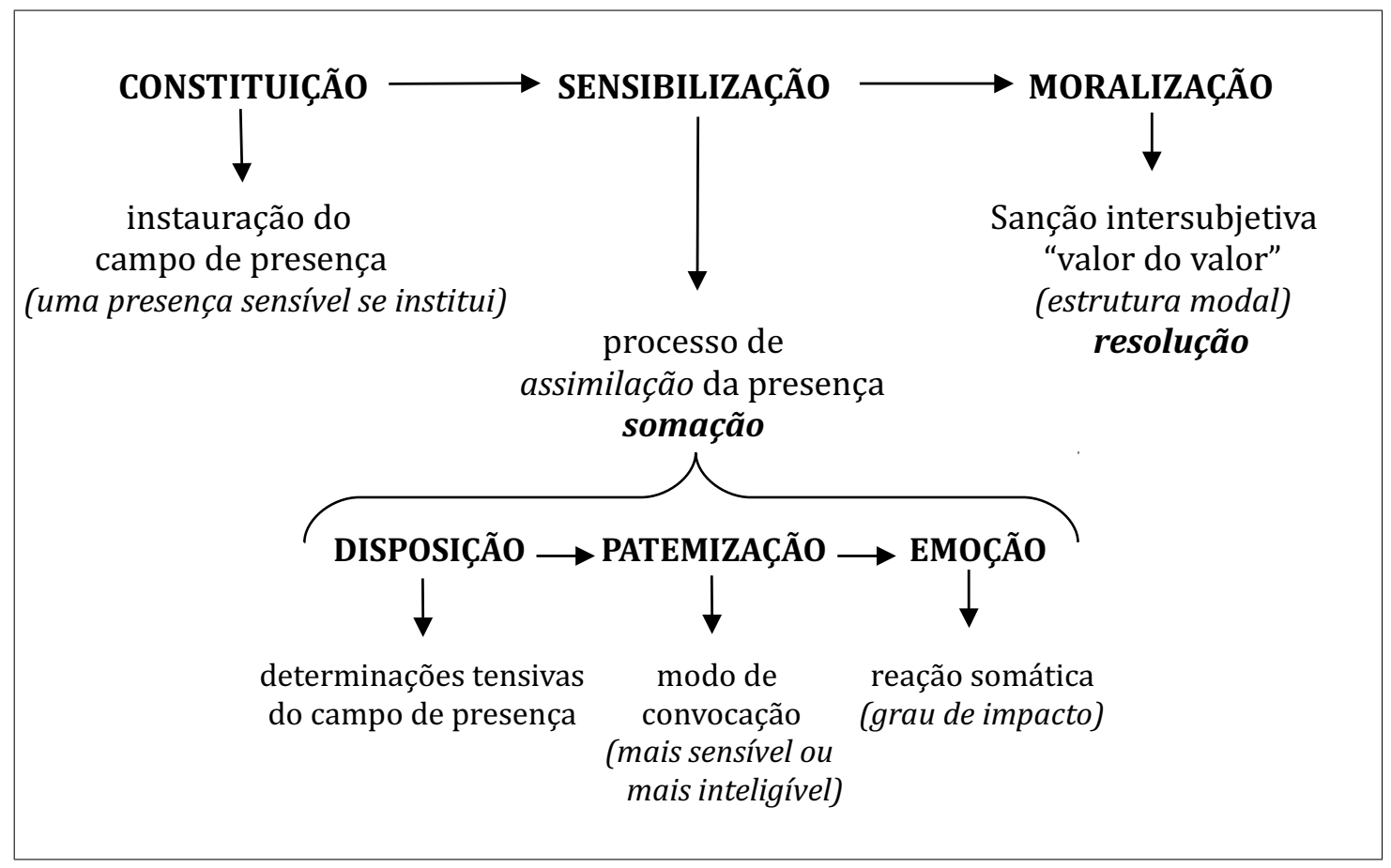

Esquema 1.7: Esquema passional canônico tensivizado (elaboração nossa a partir do esquema proposto em Semiótica das paixões, 1993).

Nesse ponto de vista de caráter prioritariamente tensivo, a percepção assume, como se vê, a primazia absoluta no processo de instauração da interação patêmica entre sujeito e objeto-valor e torna possível a apreensão e o exame não só da dinâmica sintáxica subjacente, mas também do regime de inflexões sob o qual ela se desenvolve. 0 percurso de configuração das paixões compreendido dessa maneira permite identificar o que determina a maior ou menor densidade de presença do sujeito e do objeto-valor da afetividade reciprocamente, o tipo de determinação tensiva própria a uma interação mais da ordem do sensível, como 
acreditamos ser o caso da compaixão, por exemplo, ou mais da ordem do inteligível, segundo parece verificar-se na configuração da piedade.

Essa perspectiva é semelhante às proposições de Jean-François Bordron (2002), para quem a percepção corresponde ao ato de enunciação, a um processo composto de três momentos: o indicial, referente à emergência de uma presença sensível no campo perceptivo do sujeito; o icônico, quando a presença sensível se organiza em formantes, ocupando uma certa extensão e tornando-se passível de um reconhecimento e uma identificação cognitivas; e o simbólico, responsável justamente por essa especificação, essa categorização da presença, atribuindo-lhe um sentido próprio.

Nosso interesse está, todavia, mais do que no processo de produção do sentido em si, nas regularidades sintáxicas da articulação do sensível e do inteligível, no momento de instauração das condições de emergência da interação patêmica, subjacentes à produção dos afetos. Importa-nos depreender as determinações tensivas que, como princípios organizadores do campo de presença, dirigem a ligação entre os interactantes e convocam de maneira específica uma e outra dimensão.

\subsection{Do enunciado à enunciação: a dimensão passional dos textos}

Quando o interesse pelas paixões surge na teoria, o nível de pertinência regente é ainda prioritariamente o do enunciado, excluindo do campo de interesse as questões próprias à enunciação que o produz. Isso talvez explique o fato de a análise semiótica dos afetos, conforme concebida até então, estabelecer uma relação próxima com a ação, com a estrutura narrativa, sendo desenvolvida sobretudo a partir da identificação de transformações passionais constituintes da identidade afetiva (modal) do sujeito apaixonado.

0 ponto de vista da ação, todavia, é, na teoria semiótica francesa, o da redução da complexidade discursiva, e a paixão, por sua vez, diz respeito à sobreposição, a dispositivos e dimensões provenientes de diferentes etapas do 
percurso gerativo. Como explica Fontanille (2007, p. 168):

Se reduzimos o discurso enunciado unicamente à cena predicativa, só conservamos a dimensão narrativa e formal do discurso, e seu substrato axiológico, e perdemos de vista, ao mesmo tempo, tanto a dimensão do discurso em ato como as condições de emergência dos valores. Essa concepção sobre o discurso possibilitou os avanços teóricos e metodológicos dos anos 1970 e 1980, justamente porque ela reduzia o domínio de pertinência e purificava-o de todo efeito "subjetivo". Ao "objetivar" o discurso sob a forma de um simples enunciado, essa concepção tornava possível a articulação formal. Ela deve, atualmente, ser completada pela outra concepção que adota o ponto de vista do discurso em ato.

Com o advento da tensividade, do corpo-próprio, da preocupação em compreender as (pré-)condições de emergência e configuração da significação pela percepção, isso começa a se transformar, e a problemática da enunciação ganha força, ultrapassando o status de pressuposto lógico. É quando o devir passa a ocupar o primeiro plano na investigação dos processos de significação. Conforme chama a atenção Mancini (2007, p. 105), “essa perspectiva dinâmica parece revelar uma relação estreita entre os fluxos tensivos e a expressão de suas estabilizações efêmeras no nível discursivo"; trata-se, como explica a autora (Idem, p. 98), "da organização de um campo de presença, cuja manutenção de seu devir depende de uma organização particular do campo tensivo, organização esta tributária tanto da direção do ato perceptivo (foco), quanto de sua extensão (apreensão)".

A noção de enunciação fica, dessa forma, atrelada à de percepção e à de presença, como responsável direta pela produção e estabelecimento desta última. Ela responde pela dinâmica que circunscreve e orienta a interação entre sujeito da percepção e objeto percebido. Conforme aos desenvolvimentos contemporâneos da semiótica francesa, a nova interpretação do esquema passional canônico adota também essa ideia, buscando examinar as paixões, a configuração das interações afetivas, para além da identificação e descrição de códigos estereotipados. Interessa agora depreender o instante de sua emergência, da experiência que o afeto proporciona ao sujeito patêmico no universo do discurso em ato. Ao assumir a perspectiva do devir, o percurso de análise sugerido procura, então, dar conta das 
condições de geração dos afetos em todos os níveis do percurso gerativo, porque mais do que as paixões nos textos, importa compreender também a produção delas a partir dos textos.

Assim, os afetos reconhecidos e nomeados por determinada sociedade como é o caso da compaixão e da piedade, segundo categorizadas pela cultura ocidental - interessam como maneiras de poder averiguar a coerência das hipóteses e dos dados apresentados e discutidos nesse capítulo. A eficácia do esquema passional canônico proposto será, pois, testada em análises que privilegiarão não o discurso-enunciado apenas, mas a enunciação viva; não a passionalidade enunciada, mas aquela que é (re)criada nas estratégias enunciativas, no modo como o enunciador constrói seu enunciado, no modo como ele estabelece o acesso do enunciatário ao conteúdo transmitido, o que traz à cena, além disso, a dimensão retórica dos enunciados.

$\mathrm{Na}$ análise concreta da dimensão passional dos textos, da afetividade que eles suscitam no discurso em ato, a fase da constituição será, por conseguinte, aquela do contato do enunciatário com o enunciado, da "posição" que ele passa a ocupar (mais próxima e subjetiva ou mais distante e objetiva) quando o conteúdo começa a se concretizar, a tomar forma, instaurando um campo de presença. A sensibilização, como manifestante da dimensão passional dos textos, diz respeito aos procedimentos de configuração da interação entre o enunciatário, os atores do enunciado e os entornos, todos eles portadores dos valores em questão; é a etapa de gerenciamento da tensão que define os graus de presença do objeto-valor da afetividade, o modo de envolvimento afetivo do sujeito da percepção. Na microestrutura que a constitui, a disposição responde, portanto, pela determinação do acesso ao conteúdo, ao gerenciamento do ato perceptivo que caracteriza as especificidades do campo de presença com maior ou menor profundidade; tem a ver com as estratégias de apresentação do conteúdo. A patemização, por sua vez, é a assimilação da tensão subjacente ao enunciado, à oposição dos valores semânticos de base, com o figural articulado ao figurativo. É o momento da convocação mais sensível ou mais inteligível para a apreensão da presença. A emoção é a resposta, a manifestação da recepção das tensões, a instauração do elo - 
mais tônico ou mais átono, mais sensível ou mais inteligível - entre o enunciatário e os atores do enunciado. Para fechar a macroestrutura da configuração dos estados de alma, vem a moralização, o momento no qual se concretiza e se manifesta, pela apreciação subjetiva do sujeito já sensibilizado, o "valor do valor", o afeto próprio ao estado de alma em questão.

Tendo como parâmetro o exame da configuração dos estados de alma de compaixão (mais sensível, típica ao "sentir com") e de piedade (mais inteligível, própria ao "sentir por"), passaremos, mais adiante, à exploração desse percurso de investigação em análises práticas, com o intuito de avaliar a coerência e a eficácia dessa outra possibilidade de leitura do esquema passional canônico, demonstrando a sua provável relevância para o estudo dos afetos na perspectiva semiótica.

Queremos, contudo, antes disso, propor um exame de base lexical dos estados de alma de compaixão e piedade. 0 objetivo é o de, ao seguir o caminho contrário, que vai da etapa da moralização à da constituição, do fenômeno passional estabilizado e categorizado às suas condições de emergência, demonstrar in loco o papel ocupado pelas modulações tensivas na configuração dos modos de interação afetiva e a relevância da sua inclusão no momento da análise. 
Capítulo 2

Entre compaixão e piedade: da junção à presença 
Uma das principais dificuldades da interação passional deve-se justamente ao fato de que, fora do percurso completo que compreende, entre outras coisas, a expressão somática ou verbal, a paixão de um sujeito é ilegível para o outro: o nome da paixão fornece, então, uma indicação suplementar, que reativa um esquema canônico esquecido.

Jacques Fontanille

\subsection{A análise lexical}

As paixões, do ponto de vista da semiótica francesa, interessam, conforme vimos, enquanto efeitos de sentido derivados de determinada situação de interação, apresentando-se como configurações discursivas passíveis de ser descritas por meio de propriedades sintáxicas. De um lado, elas procedem das modulações do estado do sujeito na sua relação com um objeto, com os valores nele investidos e que o tornam desejável, detestável, temível, etc. De outro, provêm da estrutura modal a partir daí instituída, definidora do 'ser' do sujeito apaixonado e da inter-relação que ele estabelece com o objeto-valor. A passionalidade nasce, dessa forma, diretamente da ligação do sujeito com o objeto, ou, mais especificamente, com o valor que ele representa; o que explica a ideia inicial de que "para explicar as paixões, é preciso recorrer às relações actanciais, aos programas e percursos narrativos" (BARROS, 2001, p. 62).

Foi pensando assim que, nos primeiros desenvolvimentos da semiótica das paixões, privilegiou-se a análise lexical, procurando examinar as paixões-lexema (cólera, avareza, ciúme, etc.) e suas expressões discursivas, a partir de uma lógica sintagmática suscetível de explicitar o processo estrutural subjacente às definições. Tratava-se do estudo de interações passionais já fixadas pelo uso em determinada cultura, as quais, além do modo próprio de convocação do sensível e do inteligível, tinham também pré-estabelecida, enquanto configurações canônicas, uma estrutura actancial e narrativa, ou seja, um conjunto de funções, ou de "signos passionais", que permitiam a sua identificação, o seu reconhecimento. É por isso que, segundo Greimas (1983), os lexemas se apresentam como condensações de 
estruturas discursivas e narrativas, contendo as primeiras informações sobre a maneira como "funcionam" as paixões. Ele explica (1983, p. $225^{50}$ ): "as descrições lexemáticas podem constituir, de modo econômico, modelos de previsibilidade para análises discursivas posteriores".

Isso explica nossa opção de, cientes do relativismo cultural ligado ao léxico, uma vez que cada língua utiliza formas variadas e específicas para conceituar comportamentos patêmicos de mesma natureza, iniciar a investigação acerca dos estados de alma de compaixão e piedade também com um exame de base lexical. Acreditamos que, mesmo mantendo relações semânticas de vizinhança e de imbricação, essas duas paixões possuem particularidades sintáxicas específicas, e podem, por isso, ser concebidas como afetos distintos. A significação dicionarizada dessas paixões-lexema nos interessa, então, como ponto de apoio para a identificação, avaliação e compreensão das características propriamente formais dos fenômenos significantes que elas nomeiam.

Assim, percorreremos, a princípio, as definições de compaixão e piedade encontradas em alguns dos dicionários das principais línguas neolatinas, o português, o francês, o italiano e o espanhol, com o intuito não de realizar uma investigação puramente semântica, mas de identificar, por meio dos dados levantados pelos semas, os dispositivos e as operações gerais presentes na produção dos dois núcleos patêmicos em pauta - segundo sua concepção na cultura ocidental -, averiguando, além disso, pelo conjunto da organização estrutural latente às definições, as semelhanças e as diferenças de um estado de alma e outro, bem como a relevância do componente tensivo-fórico para o estudo das paixões na perspectiva semiótica.

Nossa intenção é a de depreender, através desta análise, a (re)formulação sintáxica do conteúdo semântico de compaixão e piedade, transformando, como fazia Greimas, os "nomes-lexema” em "patemas-processo", e identificando, a partir daí, tanto as organizações modais subjacentes, quanto as operações tensivas que as predispõem a participar de configurações passionais mais sensíveis ou mais inteligíveis. Esperamos com isso poder definir as condições de emergência da

\footnotetext{
${ }^{50}$ Trecho original: "[...] les descriptions lexématiques peuvent constituer, de façon économique, des modèles de previsibilité pour des analyses discursives ultérieures” (GREIMAS, 1983, p. 225).
} 
interação afetiva estabelecida em um estado de alma e outro, verificando a coerência da tipologia dos modos complexos de interação afetiva proposta no capítulo anterior.

\subsection{Compaixão e piedade: levantamento das definições}

Tanto compaixão quanto piedade, independente das interpretações axiológicas que recebam nas diferentes culturas, remetem, de maneira geral, ao pesar provocado quando se testemunha o sofrimento de um ser vivo. Todavia, conforme assinala Ricot (2013, p. $9^{51}$ ), "é rude a concorrência lexical para exprimir o sentimento experimentado diante da infelicidade de outrem". Entre compaixão e piedade, há pena, dó, comiseração, lástima, condoimento, caridade, enternecimento, pesar, simpatia, etc, "como se esta multiplicação terminológica fosse o indício de uma busca desesperada por uma palavra enfim apropriada, uma ideia adequada, difícil de estabelecer em razão dos impasses encontrados em torno da própria noção e de seu papel na vida moral" (Idem, p. $9^{52}$ ).

As acepções encontradas para esses lexemas em grande parte dos dicionários de língua portuguesa, na maioria das vezes, não dizem muito a respeito da nuance entre o significado de cada um deles, colocando-os, ao contrário, como se pode observar abaixo (cf. Tabela 2.1), uns como sinônimos dos outros.

\begin{tabular}{|c|c|}
\hline \multicolumn{2}{|c|}{ CAMPO LEXICAL NO QUAL SE INSCREVEM COMPAIXÃO E PIEDADE } \\
\hline & Acepções dicionarizadas \\
\hline amerceamento & $\begin{array}{l}\text { s.m. } 1 \text { ato ou efeito de amercear(-se); amerceadura, compaixão; } 2 \\
\text { remissão total ou parcial da culpa. } \\
\text { *amercear(-se): v.t.d.p.1 conceder mercê a; compadecer-se, apiedar-se; [... }\end{array}$ \\
\hline
\end{tabular}

\footnotetext{
${ }^{51}$ Trecho original: "La concurrence lexicale est rude pour exprimer le sentiment éprouvé devant le malheur d'autrui."

${ }^{52}$ Trecho original: "Comme si cette multiplication terminologique était l'indice d'une recherche désespérée, grâce à un mot enfin approprié, d'une idée adéquate, difficile à établir en raison des écueils rencontrés autour de la notion elle-même et de son rôle dans la vie morale."
} 


\begin{tabular}{|c|c|}
\hline caridade & $\begin{array}{c}\text { S.f. [...] } 2 \text { Derivação: por metonímia. ato pelo qual se beneficia o } \\
\text { próximo, esp. os pobres e os desprotegidos; } 3 \text { disposição favorável } \\
\text { em relação a alguém em situação de inferioridade (física, moral, } \\
\text { social etc.); compaixão, benevolência, piedade; [...] }\end{array}$ \\
\hline comiseração & $\begin{array}{l}\text { s.f. sentimento de piedade pela infelicidade de outrem; compaixão, } \\
\text { miseração. }\end{array}$ \\
\hline \multirow{2}{*}{ compadecimento } & $\begin{array}{c}\text { s.m. } 1 \text { ato ou efeito de compadecer(-se); compaixão; } 1.1 \\
\text { condescendência, benevolência. }\end{array}$ \\
\hline & *compadecer(-se): v.t.d.p. 1 sentir compaixão (de), condoer-se (de). [...] \\
\hline compungimento & $\begin{array}{c}\text { *compungir(-se): v.t.d.p. }[\ldots] 2 \text { causar a, ou sentir enternecimento; } \\
\text { sensibilizar(-se). }\end{array}$ \\
\hline condoimento & $\begin{array}{l}\text { s.m. sentimento ou estado de quem se condói; compaixão, } \\
\text { condolência, pena. }\end{array}$ \\
\hline condolência & $\begin{array}{l}\text { s.f. } 1 \text { estado de quem se condói; sentimento de pesar; compaixão, } \\
\text { pena. [...] }\end{array}$ \\
\hline dó & $\begin{array}{l}\text { s.m.1 sentimento de pena com relação a alguém, a si mesmo ou a } \\
\text { alguma coisa; compaixão; } 2 \text { expressão de grande tristeza e mágoa } \\
\text { por alguém, por si ou por alguma coisa; pesar. [...] }\end{array}$ \\
\hline enternecimento & $\begin{array}{c}\text { s.m. [...] } 2 \text { sentimento de pena com relação a alguém, a si mesmo ou } \\
\text { a coisa; compaixão, dó. }\end{array}$ \\
\hline lástima & $\begin{array}{l}\text { s.f. ato ou efeito de lastimar(-se); } 1 \text { sentimento de pena; compaixão, } \\
\text { dó; } 2 \text { Derivação: por metonímia. Aquilo que merece ser lastimado; } \\
\text { mal; } 3 \text { lamentação interminável; queixa, lamúria; } 4 \text { revés da fortuna; } \\
\text { desgraça, desdita, infortúnio. }\end{array}$ \\
\hline misericórdia & $\begin{array}{l}\text { s.f. } 1 \text { sentimento de dor e solidariedade com relação a alguém que } \\
\text { sofre uma tragédia pessoal ou que caiu em desgraça; dó, compaixão, } \\
\text { piedade; } 2 \text { ato concreto de manifestação desse sentimento, } \\
\text { como o perdão; indulgência, graça, clemência. [...] }\end{array}$ \\
\hline pena & $\begin{array}{l}\text { s.f. } 2 \text { sofrimento; aflição; } 3 \text { compaixão, piedade, comiseração; } \\
4 \text { tristeza, amargura, pesar. }[. . .]\end{array}$ \\
\hline pesar & [...] s.m.12 sentimento de tristeza, de desolação. \\
\hline
\end{tabular}




\begin{tabular}{|c|c|}
\hline simpatia & $\begin{array}{l}\text { s.f. } 1 \text { afinidade moral, similitude no sentir e no pensar que aproxima } \\
\text { duas ou mais pessoas; }[. . .] 5 \text { faculdade de compenetrar-se das ideias } \\
\text { ou sentimentos de outrem; }[\ldots]\end{array}$ \\
\hline \multicolumn{2}{|c|}{ Fonte: Dicionário Houaiss da Língua Portuguesa. 1.ed. Rio de Janeiro: Objetiva; $2009^{53}$. } \\
\hline
\end{tabular}

Tabela 2.1: Tabela comparativa do léxico em língua portuguesa relacionado ao campo semântico de compaixão e piedade.

Mesmo as definições de compaixão e piedade nos dicionários de língua portuguesa consultados, embora chamem, em alguns casos, a atenção para certa distinção entre as acepções, na maioria das vezes, cruzam os conteúdos, apresentando um termo como sinônimo do outro (cf. Tabela 2.2).

\begin{tabular}{|c|c|}
\hline COMPAIXÃO & PIEDADE \\
\hline \multicolumn{2}{|c|}{ Acepções dicionarizadas } \\
\hline $\begin{array}{l}\text { S.f. sentimento que nos desperta a } \\
\text { desgraça; pesar que nos desperta o mal } \\
\text { alheio, dó; comiseração; o estado daqueles } \\
\text { infelizes causa compaixão; [...] }\end{array}$ & $\begin{array}{c}\text { s.f. Devoção, amor e respeito pelas coisas } \\
\text { religiosas; religião, devoção. // Respeito } \\
\text { pelos mortos. // Sentimento inspirado } \\
\text { pelos males alheios e que se dispõe a } \\
\text { remediá-los ou a mitigá-los. // Compaixão; } \\
\text { dó; comiseração. [...] }\end{array}$ \\
\hline $\begin{array}{l}\text { Fonte: Dicionário contemporâneo da Língua } \\
\text { Portuguesa, vol. 1, Caldas Aulete, } 4^{\mathrm{a}} \text { ed., Rio de } \\
\text { Janeiro: Delta, } 1958 .\end{array}$ & $\begin{array}{c}\text { Fonte: Dicionário contemporâneo da Língua } \\
\text { Portuguesa, vol. 4, Caldas Aulete, } 4^{\text {a }} \text { ed., Rio de } \\
\text { Janeiro: Delta, } 1958 .\end{array}$ \\
\hline $\begin{array}{l}\text { s.f. Pesar que em nós desperta a } \\
\text { infelicidade, a dor, o mal de outrem; } \\
\text { piedade, pena, dó, condolência. }\end{array}$ & $\begin{array}{l}\text { s.f. } 1 \text { Amor e respeito às coisas religiosas; } \\
\text { religiosidade; devoção. } 2 \text { Pena dos males } \\
\text { alheios; compaixão, dó, comiseração; [...] }\end{array}$ \\
\hline $\begin{array}{c}\text { Fonte: Novo Aurélio Século XXI: o dicionário da } \\
\text { língua portuguesa, } 3^{a} \text { ed., Rio de Janeiro: Nova } \\
\text { Fronteira, } 1999 .\end{array}$ & $\begin{array}{c}\text { Fonte: Novo Aurélio Século XXI: o dicionário da } \\
\text { língua portuguesa, } 3^{a} \text { ed., Rio de Janeiro: Nova } \\
\text { Fronteira, } 1999 .\end{array}$ \\
\hline
\end{tabular}

\footnotetext{
${ }^{53}$ Embora só as definições do Dicionário Houaiss da lingua portuguesa tenham sido aqui elencadas, a consulta estendeu-se a vários outros dicionários de português. A opção pela apresentação de um único, como representante da língua de um modo geral, deve-se à falta de distinção significativa entre as acepções encontradas.
} 


\begin{tabular}{|c|c|}
\hline $\begin{array}{l}\text { s.f. sentimento piedoso de simpatia para } \\
\text { com a tragédia pessoal de outrem, } \\
\text { acompanhado do desejo de minorá-la; } \\
\text { participação espiritual na infelicidade } \\
\text { alheia que suscita um impulso altruísta de } \\
\text { ternura para com o sofredor. }\end{array}$ & $\begin{array}{l}\text { s.f. } 1 \text { devoção, amor pelas coisas religiosas; } \\
\text { religiosidade; } 1.1 \text { Rubrica: religião; virtude } \\
\text { que permite render a Deus o culto que lhe } \\
\text { é devido; } 2 \text { compaixão pelo sofrimento } \\
\text { alheio; comiseração, dó, misericórdia. }\end{array}$ \\
\hline $\begin{array}{c}\text { Fonte: Dicionário Houaiss da Língua Portuguesa. } \\
\text { 1.ed. Rio de Janeiro: Objetiva; } 2009 .\end{array}$ & $\begin{array}{l}\text { Fonte: Dicionário Houaiss da Língua Portuguesa. } \\
\text { 1.ed. Rio de Janeiro: Objetiva; } 2009 .\end{array}$ \\
\hline $\begin{array}{l}\text { s.f. } 1 \text {. Sentimento benévolo que nos inspira } \\
\text { a infelicidade ou o mal alheio. } \\
\text { 2. Dó; lástima; piedade. }\end{array}$ & $\begin{array}{l}\text { 1. Prática das leis religiosas. = DEVOÇÃO } \\
\text { 2. Vontade de diminuir ou se solidarizar } \\
\text { com o sofrimento alheio. = COMPAIXÃO, } \\
\text { DÓ, LÁSTIMA, MISERICÓRDIA }\end{array}$ \\
\hline $\begin{array}{l}\text { Fonte: Dicionário Priberam da Língua Portuguesa } \\
\text { [em linha], 2008-2013, } \\
\text { http://www.priberam.pt/DLPO/compaix\%C3\%A3o } \\
\text { [consultado em 28-11-2013]. }\end{array}$ & $\begin{array}{c}\text { Fonte: Dicionário Priberam da Língua Portuguesa } \\
\text { [em linha], 2008-2013, } \\
\text { http://www.priberam.pt/DLPO/piedade } \\
\text { [consultado em 28-11-2013]. }\end{array}$ \\
\hline
\end{tabular}

Tabela 2.2: Tabela comparativa das definições de compaixão e piedade encontradas em dicionários de língua portuguesa.

Embora haja uma remissão à religiosidade, a certo "dever religioso", no caso da piedade, que não aparece na definição de compaixão, essas duas paixões "nucleares", se assim podemos dizer, são claramente concebidas como sendo sinônimas. Na designação de compaixão aparece o termo "sentimento piedoso", "piedade", e, do mesmo modo, na de piedade há sempre a referência à compaixão. Com os termos "periféricos" o mesmo se verifica, e o que temos é na maioria das vezes um grupo de palavras consideradas parassinônimas, que remetem umas às outras sem maior detalhamento da nuance existente entre as interações afetivas distintamente nomeadas.

Se pensarmos, por outro lado, na práxis enunciativa envolvida no uso dessas paixões-lexema, a relação de sinonímia entre elas parece se diluir um pouco, e um termo é frequentemente preferido em vista dos outros, a depender da situação e da conotação que queremos afirmar ou negar. Isso porque, mesmo com as definições dicionarizadas não salientando a diferença entre uma paixão e outra, sabemos que o sentimento de pesar pelo padecimento de outrem pode se apresentar tanto de forma natural, irrefletida - quando há mesmo um movimento de partilha da dor 
daquele que sofre, um "sentir com" -, quanto como resultado de uma avaliação menos espontânea, mais cognitiva, a partir da qual o observador, ao assumir uma perspectiva exterior e objetiva, compara a sua situação positiva àquela disfórica do sofredor, sensibilizando-se mediante um "sentir por", que põe em cena não a comunhão de sentimentos, mas uma relação de alteridade entre um e outro, entre aquele que testemunha o padecimento e aquele que o vive. Como assinala Rousseau (2004, p. 310), “a piedade é doce, porque, ao nos colocarmos no lugar daquele que sofre, sentimos contudo o prazer de não sofrer com ele".

De acordo com Ricot (2013, p. 10 ${ }^{54}$ ), “a língua hesita hoje em usar a palavra piedade porque o termo acabou adquirindo no uso uma significação de condescendência, e mesmo de desprezo e desdém, que parece não ter contaminado tão fortemente o de compaixão". De fato, nos dicionários de referência da língua francesa (cf. Tabela 2.3), por exemplo, as definições de compaixão e piedade apontam mais claramente para essa diferença de configuração da identificação entre os sujeitos em cada um dos casos. Mesmo concebidas como estados de alma sinônimos, na acepção de compaixão aparece o sema da partilha; o que não acontece no caso da piedade, quando se faz inclusive menção a certo desprezo.

\begin{tabular}{|c|c|}
\hline COMPASSION (Compaixão) & PITIÉ (Piedade) \\
\hline \multicolumn{2}{|c|}{ Acepções encontradas em dicionários de língua francesa } \\
\hline nf Sentiment qui nous fait compatir. & $n f$ 1 Sentiment qui saisit à la vue des \\
2 État de celui qui est à plaindre. & $\begin{array}{c}\text { souffrances et qui porte à les soulager. } 2 \\
\text { Pitié, se dit quelquefois en un sens où il } \\
\text { entre quelque mépris. }\end{array}$ \\
$\begin{array}{c}\text { sf Sentimento que nos faz sofrer com o outro. } \\
\text { 2 Estado daquele por quem se lamenta. }\end{array}$ & $\begin{array}{c}s f \text { 1 Sentimento que nos toma ante os } \\
\text { sofrimentos de outrem e que nos inclina a } \\
\text { aliviá-los. 2 Piedade, diz-se algumas vezes com } \\
\text { algum desprezo }\end{array}$ \\
$\begin{array}{c}\text { Fonte: Dictionnaire de français Littré (en ligne). } \\
\text { Disponível em: http://littre.reverso.net/ } \\
\text { dictionnaire-francais/definition/compassion }\end{array}$ & $\begin{array}{c}\text { Fisponível em: http://littre.reverso.net/dictionnaire- } \\
\text { francais/definition/compassion }\end{array}$ \\
\hline
\end{tabular}

\footnotetext{
${ }^{54}$ Trecho original: “[...] la langue hésite aujourd'hui à employer le mot de pitié parce que le terme a pris, assez souvent dans l'usage, une signification de condescendance, voire de mépris et de dédain, qui semble avoir moins contaminé celui de compassion."
} 


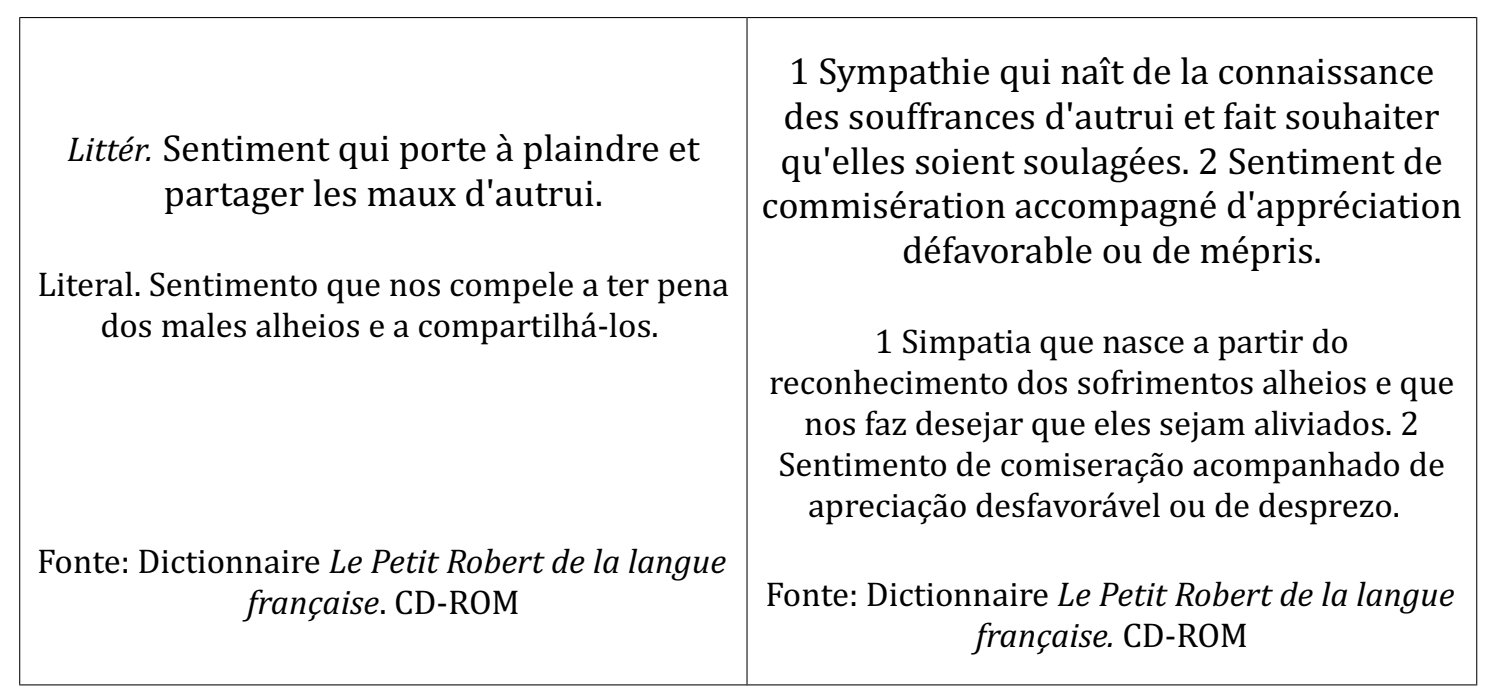

Tabela 2.3: Tabela comparativa das definições encontradas em dicionários de língua francesa.

Nos dicionários de língua italiana, por sua vez, embora os termos compaixão e piedade também apareçam como sinônimos, com os dois "tipos de pesar" sendo mencionados, ocorre exatamente o contrário, e é a piedade o afeto definido de maneira mais positiva, euforizada, considerada como um sentimento forte, de natureza propriamente patêmica, e não a compaixão, a qual está associada o sema pejorativo do desprezo e do desdém. Mesmo com a presença do sema da "partilha", do "sentir com", o sentimento compassivo é, na maioria das vezes, como se pode observar no quadro comparativo reproduzido abaixo (cf. Tabela 2.4) ${ }^{55}$, passível de uma apreciação negativa, disforizada.

\begin{tabular}{|c|c|}
\hline COMPASSIONE (Compaixão) & PIETÀ (Piedade) \\
\hline \multicolumn{2}{|c|}{ Acepções encontradas em dicionários de língua italiana } \\
\hline $\begin{array}{c}\text { s.f. } 1 \text { Atteggiamento comprensivo e } \\
\text { soccorrevole di fronte ad uno stato penoso } \\
\text { [... Situazione o condizione che induca a } \\
\text { assistere altri con la própria partecipazione } \\
\text { affetiva. 2 Reazione negativa sottolineata da } \\
\text { disprezzo, di fronte alle azione o al } \\
\text { comportamento altrui }[. . .]\end{array}$ & $\begin{array}{c}\text { s.f. } 1 \text { Sentimento di dolorosa e premurosa } \\
\text { partecipazione alla infelicità altrui [...] } 2 \\
\text { lett. La riverenza o la devozione, in quanto } \\
\text { riconducibili all'ambito degli affetti o dei } \\
\text { doveri domestici, sociali, religiosi [...] }\end{array}$ \\
\hline
\end{tabular}

\footnotetext{
${ }^{55}$ A tradução dos verbetes em italiano foi gentilmente feita por Carolina Tomasi.
} 
s.f. 1 Comportamento compreensivo e auxiliador diante de um estado penoso [...] Situação ou condição que induz a ajudar outras pessoas, participando afetivamente. 2. Reação negativa acentuada pela indiferença diante de ações ou do comportamento alheio [...]

Fonte: DEVOTO, Giacomo; OLI, Gian Carlo Dizionario della Lingua Italiana. Firenze: Le monnier, 1971.

s.f. 1 Sentimento di sofferto partecipazione ai dolori altrui [...] 2 sentimento di disprezza e insofferenza verso qcn. o qcs. che è meschino, ridicolo, brutto [...] SIN. 1 clemenza, comiserazione, misericordia, pena, pietà $[\ldots]$

s.f. 1 Sentimento de sofrida participação nas dores alheias. [...] 2 sentimento de desdém e de intolerância para com qualquer pessoa ou qualquer coisa, que é mesquinha, ridícula,

desagradável [...]. SIN. 1. Clemência, comiseração, misericórdia, pena, piedade [...]

Fonte: Grande Dizionario italiano dell'uso. Torino: Editrice Torinense, 2000.

s.f. 1 Sentimento di pietà verso chi è infelice, verso i suoi dolori, le sue disgrazie, i suoi difetti; partecipazione alle sofferenze altrui $[\ldots]$
S.f. 1 Sentimento de dolorosa e atenciosa participação na infelicidade alheia [...]. 2. (lit.) A reverência ou a devoção enquanto direcionadas aos afetos ou aos deveres domésticos, sociais, religiosos $[\ldots]$

Fonte: DEVOTO, Giacomo; OLI, Gian Carlo Dizionario della Lingua Italiana. Firenze: Le monnier, 1971.

S.f. 1 Sentimento di compassione, partecipazione e solidarietá per la soffrenza o l'infelicità altrui [...] 2 affeto, amore e respetto verso qcn. o qcs. [...] 3a relig., nel cristianesimo, uno dei setti doni dello Spirito Santo che consente di sviluppare e perfezionare la virtù della guistizia $3 \mathrm{~b}$ relig., culto, devozione religiosa [...] SIN. 1 clemenza, commiserazione, compassione, indulgenza, misericordia, umanità 2 affetto, amore, rispetto, pietas. CONTR. 1 cinismo, crudeltà, durezza, insensibilità 2 disprezzo, irriverenza, odio [...]

S.f. 1 Sentimento de compaixão, participação e solidariedade pelo sofrimento ou infelicidade de outrem [...] 2. Afeto, amor e respeito a qualquer pessoa ou a qualquer coisa [...]. 3a. Relig., no cristianismo, um dos sete dons do Espírito Santo que permite desenvolver e aperfeiçoar a virtude da justiça. 3b. Relig., culto, devoção religiosa [...]. SIN. 1 clemência, comiseração, compaixão, indulgência, misericórdia, humanidade 2 afeto, amor, respeito, piedade. CONTR. 1 cinismo, crueldade, dureza, insensibilidade 2 desprezo, irreverência, ódio [...]

Fonte: Grande Dizionario italiano dell'uso. Torino: Editrice Torinense, 2000.

s.f. 1 a. Sentimento di affettuoso dolore, di commossa e intensa partecipazione e di solidarietà che si prova nei confronti di chi soffre $[\ldots]$ 
s.f. 1 Sentimento de piedade por aquele que é infeliz, por suas dores, suas desgraças e seus defeitos; participação no sofrimento do outro $[\ldots]$

Fonte: Treccani. it L'enciclopedia italiana. Disponível em: http://www.treccani.it/vocabolario/tag /compassione/ s.f. 1 a. Sentimento de afetuosa dor, de comoção e intensa participação e de solidariedade que se experimenta em relação a quem sofre [...].

Fonte: Treccani. it L'enciclopedia italiana. Disponível em: http://www.treccani.it/vocabolario/tag/pieta/

Tabela 2.4: Tabela comparativa das definições de compaixão e piedade encontradas em dicionários de língua Italiana.

Nos dicionários de espanhol, compaixão e piedade também são consideradas sinônimas, mas a constância do sema da religiosidade na definição desta última (cf. Tabela 2.5) chama a atenção, apontando para a conotação do "dever" (moral) presente nesse tipo de interação. Diferentemente do que acontece nos outros dicionários examinados, nos quais esse sema pode aparecer explicitado ou não, no contexto espanhol, sua presença é fato consolidado. 0 que, de certa forma, faz subentender, por comparação, uma interpretação sobre a natureza mais espontânea do sentimento de compaixão.

\begin{tabular}{|c|c|}
\hline COMPASIÓN (Compaixão) & PIEDAD (Piedade) \\
\hline \multicolumn{2}{|c|}{ Acepções encontradas em dicionários de língua espanhola } \\
\hline \begin{tabular}{c|c} 
s/f Sentimiento de lástima por el mal o \\
desgracia ajenos[...] SIN. Commiseración, \\
lástima, piedad, misericordia, caridad. ANT. \\
Insensibilidad, crueldad.
\end{tabular} & $\begin{array}{c}\text { s/f } 1 \text { Compasión hacia la persona que sufre. } \\
\text { 2 Celo en el cumplimiento de los deberes } \\
\text { religiosos. SIN. 1 Misericordia, lástima. 2 } \\
\text { Caridad, veneración. 3 Devoción. }\end{array}$ \\
$\begin{array}{c}\text { s/f Sentimento de lástima pelo mal ou desgraça } \\
\text { alheios [...] SIN. Comiseração, lástima, piedade, } \\
\text { misericórdia, caridade. ANT. Insensibilidade, } \\
\text { crueldade. }\end{array}$ & $\begin{array}{c}\text { s/f } 1 \text { Compaixão pela pessoa que sofre. 2 Amor } \\
\text { aos pais e às coisas sagradas. 3 Zelo no } \\
\text { cumprimento dos deveres religiosos. SIN. 1 } \\
\text { Misericórdia, lástima. 2 Caridade, veneração. 3 } \\
\text { Devoção. }\end{array}$ \\
$\begin{array}{c}\text { Fonte: Gran Diccionario de la lenga española. } \\
\text { Alcabendas-Madrid, Sociedad General Española de } \\
\text { Libreria, 1985. }\end{array}$ & $\begin{array}{c}\text { Fonte: Gran Diccionario de la lenga española. } \\
\text { Alcabendas-Madrid, Sociedad General Española de } \\
\text { Libreria, 1985. }\end{array}$ \\
\hline
\end{tabular}


$s / f$ Lástima, ternura y comprensión que una persona siente hacia outra que sufre o tiene problemas [...] SIN. Misericordia, commiseración, piedad. ANT. Insensibilidad, crueldad.

$s / f$ Lástima, ternura e compreensão que uma pessoa sente por outra que sofre ou tem problemas [...]

SIN. 1 Misericórdia, comiseração, piedade. ANT. Insensibilidade, crueldade.

Fonte: Gran diccionario de uso del español actual. Alcabendas-Madrid, Sociedad General Española de Libreria, 2001.

f. Sentimiento de commiseración y lástima que se tiene hacia quienes sufren penalidades o desgracias.

f. Sentimento de comiseração e lástima que sentimos diante aqueles que sofrem penalidades ou desgraças.

Fonte: Diccionario de la Lengua Española. Real Academia Española, 2001, tomo I. $s / f 1$ Sentimiento de compasión por alguien que sufre [...] 2 Sentimiento de religiosidad y dévocion por lo que es o se considera sagrado o digno de veneración [...] SIN. 1 Compasión, clemencia, misericordia. 2 Fervor, devoción.

$s / f$ Sentimento de compaixão por alguém que sofre [...] 2 Sentimento de religiosidade e devoção pelo que é ou se considera sagrado ou digno de veneração [...] SIN. 1 Compaixão, clemência, misericórdia. 2 Fervor, devoção.

Fonte: Gran diccionario de uso del español actual. Alcabendas-Madrid, Sociedad General Española de Libreria, 2001.

$f$. Virtud que inspira, por el amor a Dios, tierna devoción a las cosas santas, y, por el amor al prójimo, actos de amor y compasión. // 2 Amor entrañable que consagramos a los padres y a objetos venerandos. // 3 Lástima, misericórdia, commiseración [...]

$f$ Virtude que inspira, pelo amor a Deus, terna devoção às coisas santas, e, por amos ao próximo, atos de amor e compaixão. // 2 Grande amor que devotamos aos pais e aos objetos veneráveis. // 3 Lástima, misericórdia, comiseração [...]

Fonte: Diccionario de la Lengua Española. Real Academia Española, 2001, tomo I.

Tabela 2.5: Tabela comparativa das definições de compaixão e piedade encontradas em dicionários de língua espanhola.

Esse levantamento das definições de compaixão e piedade nos dicionários das principais línguas neolatinas permite constatar que, mesmo sendo concebidas como paixões sinônimas, de tal forma que as acepções se cruzam e até mesmo se confundem, existem, com efeito, duas experiências passionais possíveis subjacentes ao estabelecimento do pesar pelo sofrimento de outrem: uma originária da plena identificação com o outro, própria ao "sentir com", e a outra de uma posição de alteridade em relação a seu padecimento, atrelada ao "sentir por". 
0 vestígio, no léxico, dessa assimilação da diferença qualitativa no modo de configuração da interação afetiva instaurada a partir da observação da dor alheia se esclarece quando examinamos a raiz etimológica dos termos em questão (cf. Tabela 2.6).

\begin{tabular}{|c|c|}
\hline COMPAIXÃO & PIEDADE \\
\hline \multicolumn{2}{|c|}{ Etimologia } \\
\hline $\begin{array}{l}\text { lat. compassio,ónis 'comunidade de } \\
\text { sentimentos, } \underline{\text { sofrimento comum'. }}\end{array}$ & $\begin{array}{c}\text { lat. piètas,átis 'cumprimento do dever } \\
\text { virtude, justiça, fidelidade'. }\end{array}$ \\
\hline \multicolumn{2}{|c|}{ Fonte: Dicionário Houaiss da Língua Portuguesa. 1.ed. Rio de Janeiro: Objetiva; 2009, (grifo nosso). } \\
\hline $\begin{array}{l}\text { CŌMPĀSSǏŎ, ŌNǏS, s. ap. f. (de compatí) } \\
\text { TERT. Soffrimento commum. § Comunhão, } \\
\text { participação. Compassio sententiarum. } \\
\text { TERT. Communhão de opiniões. § PROP. } \\
\text { FORT. Compaixão. [...] }\end{array}$ & 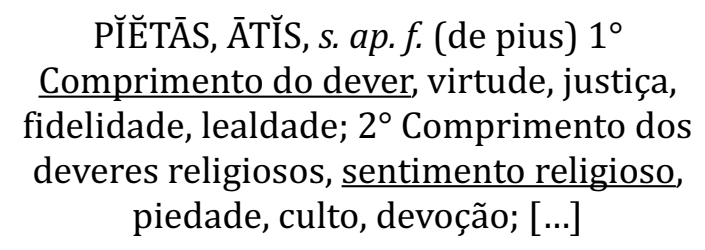 \\
\hline $\begin{array}{l}\text { CŌMPĀSSĬBĬLIIS, Ě, adj. (de compatí) TERT. } \\
\text { Que soffre com, que partilha o sofrimento. } \\
\S[\ldots]\end{array}$ & $\begin{array}{l}\text { PIŬS, } \breve{A}, \breve{U M}, \text { adj. Que cumpre o dever, } \\
\text { virtuoso, puro, justo, } \underline{\text { honrado, honesto, }} \\
\text { casto; }[\ldots] 2^{\circ} \text { Que presta o culto devido aos } \\
\text { deuses, piedoso, pio, religioso; devoto; }[\ldots]\end{array}$ \\
\hline $\begin{array}{l}\text { Fonte: SARAIVA, F. R. dos S. Novíssimo dicionário } \\
\text { Quicherat. 11ed. Rio de Janeiro: Li }\end{array}$ & $\begin{array}{l}\text { latino-portugês. Redigido segundo o plano de L. } \\
\text { raria Garnier, 2000, (grifo nosso). }\end{array}$ \\
\hline
\end{tabular}

Tabela 2.6: Tabela comparativa da raiz etimológica de compaixão e piedade.

A identificação dos dois "tipos de pesar", que de certa forma ainda hoje recobrem, na prática discursiva, o campo semântico de compaixão e piedade, corresponde, como se pode ver, a resquícios da etimologia. 0 sentimento de partilha, de plena identificação com o sofrimento alheio percebido e sentido como sendo próprio diz respeito, a partir desse fundamento etimológico, à compaixão "compassio, comunidade de sentimentos; sentimento comum"; enquanto o outro, mais próximo a uma obrigação moral, à ideia de conduta esperada, virtuosa, referese à piedade - "pietas, cumprimento do dever; virtude; justiça; fidelidade"- cujo grande exemplo literário é Eneias, da Eneida de Virgílio, qualificado pio, embora 
não haja em sua conduta nenhuma manifestação própria ao sentimento de compaixão.

Nesse sentido, mesmo havendo a frequente "mistura" e "confusão" entre os nomes dados a esses fenômenos passionais, com um tomado pelo outro - piedade como compaixão, ou vice-versa, ou reconhecidos ainda como dó, pena, comiseração, lástima, pesar, etc. -, a distinção entre duas formas de lamentar o sofrimento alheio é evidente, o que chama a atenção para a distinção semântica em cada um dos casos. Conforme explica Ricot (2013, p. $\left.13^{56}\right)$ :

Ser tomado de compaixão, compartilhar, "sentir com", da mesma forma que sentir comiseração, é experimentar uma emoção ante a miséria de outrem. Sobre esse aspecto, a compaixão possui uma vantagem inscrita na estrutura de sua etimologia latina, pois ela indica explicitamente a partilha do sofrimento: a relação com o outro, legível diretamente na própria palavra [...].

Ele acrescenta (Idem, p. $21^{57}$ ): “a comiseração é 'um sentimento que nos coloca no lugar daquele que sofre', porque nos comunicamos diretamente com o seu sofrimento. [...] Sofrer 'com' o outro é, portanto, sofrer 'como' o outro". Esse tipo de posicionamento perante a dor de outrem seria, contudo, diferente daquele característico à piedade, quando, conforme assinala o autor (Idem, p. 21-22 ${ }^{58}$ ):

[...] o padecimento do outro não é o meu. Posso ser afetado pelo seu sofrimento, mas tal sofrimento não é o meu; não sinto o que ele sente, nem imediata, nem diretamente. [...] Identificação não imediata, mas mediada: ela exige uma 'mediação' que traz à cena a irredutível alteridade daquele que é, no entanto, meu semelhante.

Trata-se, portanto, de posicionamentos e modos de interação afetiva

\footnotetext{
${ }_{56}^{56}$ Trecho original: "Être ému de compassion, compatir, 'pâtir avec', de même qu'éprouver de la commisération, c'est ressentir une émotion à la vue de la misère d'autrui. Par ce trait, la compassion possède un avantage inscrit dans la structure de son étymologie latine puisqu'elle indique explicitement la co-souffrance: la relation à l'autre, lisible très directement dans le mot lui-même [...]."

${ }^{57}$ Trecho original: "La commisération est 'un sentiment qui nous met à la place de celui qui souffre' parce que sa souffrance se communique à nous directement. [...] Pâtir 'avec' autrui serait donc pâtir 'comme' autrui."

${ }^{58}$ Trecho original: "[...] la souffrance d'autrui n'est pas la mienne. Je peux être affecté par sa souffrance, mais cette souffrance n'est pas ma souffrance, je n'éprouve pas immédiatement et directement ce qu'il éprouve [...] Identification non pas immédiate mais médiate: elle exige une 'médiation' qui tienne compte de l'irréductible altérité de celui qui est pourtant mon semblable."
} 
diversificados perante o padecimento de outrem, a partir dos quais se pode estabelecer tanto uma identificação fusional, que coloca os interactantes em uma posição de igualdade, de sincronização patêmica, quanto uma identificação com o sofrimento do outro marcada pela posição de alteridade, na qual se mantém um distanciamento, garantindo ao observador, pelo fato de se encontrar em melhor situação, certa superioridade. Nas palavras de Fontanille $\left(2005\right.$, p. $\left.241^{59}\right)$, "no primeiro caso, o outro é tratado como um semelhante no movimento mesmo de uma identificação-participação; e, no segundo caso, a avaliação é comparativa, e não absoluta [...]".

A compaixão, ao carregar os semas do "comum", da "comunhão", é, dessa forma, um sentimento mais espontâneo, de origem natural e instintiva, uma partilha mesmo do padecimento do outro, um "sentir junto", isto é, um "sentir com". A piedade, por outro lado, ressaltando o dever moral e a religiosidade, a virtude, aponta para o domínio da razão na configuração afetiva, para a determinação social do estado de alma, a obrigação do sentir em relação ao mal vivido pelo outro, e caracteriza a alteridade e a dissimetria intersubjetiva que configura $o$ compadecimento pelo outro, o "sentir por".

A distinção entre essas duas formas de pesar aparece também nos estudos realizados pelos filósofos que voltaram a sua atenção a esse tipo de sentimento Rousseau (1755, 1762, 1776), Adam Smith (1759), Schopenhauer (1840), Kant $(1785,1788)$, Nietzsche $(1882,1888)$, entre outros - com a interação assentada no "sentir com" frequentemente exaltada, enquanto a conduta de "sentir por" é, na maioria das vezes, veementemente recriminada.

De toda forma, é preciso ir além de uma simples interpretação dos semas. É necessário, como salientavam Greimas e Fontanille (1993), estabelecer, a partir dos segmentos definicionais levantados, os elementos do processo de configuração de tais estados de alma, de modo que o importante agora é compreender quais circunstâncias de estabelecimento da interação patêmica fazem com que a compaixão seja mais ligada ao sentimento de pesar em si, à identificação e à

59 Trecho original: “[...] dans le premier cas, l'autre est traité comme un semblable dans le mouvement même de participation-identification; et, dans le second cas, l'évaluation est comparative, et non absolue [...]" 
sensibilização passional que suscitam uma interação tônica, um "sentir com", sendo mais da ordem do sensível, enquanto a piedade, a uma avaliação mais objetiva e distanciada da situação de sofrimento alheio, à alteridade e à moralização, ao inteligível, fazendo surgir um "sentir por" com menor interação intersubjetiva.

Nossa hipótese é a de que essa diferença na natureza qualitativa do pesar em questão, bem como o "peso" que o sensível e o inteligível adquirem no processo de instauração da interação afetiva, estão ligados ao modo como o sujeito apaixonado, seja o compassivo, seja o piedoso, percebe o sofrimento do outro, às condições de acesso ao conteúdo, isto é, aos valores que caracterizam a cena passional em questão.

\subsection{A tradução sintáxica da significação: a estrutura subjacente à definição}

0 ponto de vista da semiótica das paixões é, como vimos no capítulo anterior, o da complexidade, ou seja, o da correlação entre dispositivos e dimensões provenientes de diversos níveis de geração do sentido, de maneira que a todo estado passional subjaz uma estrutura sintáxico-narrativa da qual é possível identificar não só os dispositivos modais, encontrados no fulcro da existência semiótica do sujeito apaixonado, mas também, como temos defendido, as condições subjacentes a sua configuração.

Greimas e Fontanille, no exame da avareza (1993, p. 101), explicam que "o estudo dos lexemas passionais exige primeiro a substituição de uma definição à sua denominação, depois uma reformulação sintática da própria definição", esclarecendo: "trata-se, em suma, de transformar papéis patêmicos, cujos 'nomeslexema' atestam a existência em dado uso, em patemas-processo e de pôr às claras, graças à análise e à catálise conjugadas, as organizações modais subjacentes".

O primeiro passo da investigação, de acordo com a maneira de analisar dos autores citados, deve ser, por conseguinte, um levantamento dos segmentos definicionais (cf. Tabela 2.7) que estão na base dos lexemas examinados, por serem eles os detentores das principais características (sintáxicas) do modo de interação afetiva típico à paixão estudada, à cena narrativa em questão. 
No exame das condições de configuração dos efeitos passionais de compaixão e piedade privilegiaremos, pois, ao defender a distinção entre eles, os semas passíveis de ser depreendidos a partir da raiz etimológica dos lexemas. Temos, então:

\begin{tabular}{|c|c|}
\hline COMPAIXÃo & PIEDADE \\
\hline $\begin{array}{c}\text { sofrimento comum; comunhão, } \\
\text { participação. }\end{array}$ & $\begin{array}{c}\text { cumprimento do dever; } \\
\text { religiosidade, virtude. }\end{array}$ \\
\hline simetria; identificação. & dissimetria; alteridade. \\
\hline "sentir com" & "sentir por" \\
\hline
\end{tabular}

Tabela 2.7: Descrição dos segmentos definicionais dos termos em análise.

Cientes de que se trata, em ambos os casos, do sentimento-resposta perante o padecimento de outrem, uma primeira constatação a propósito da semelhança do dispositivo actancial pode ser feita: para que o sentimento de compaixão e/ou piedade surja, é preciso haver, independente do investimento figurativo que recebam no nível discursivo, (i) um dano, (ii) um sujeito por ele afetado e (iii) um sujeito que testemunha a cena em questão. Ademais, essa primeira imposição estrutural nos leva a inferir ainda um ou outro princípio comum entre os dois estados de alma: a relação intersubjetiva entre os sujeitos envolvidos - o sofredor, objeto-valor ao qual a afetividade suscitada é dirigida; e a testemunha do padecimento, o sujeito da percepção -, assentada no componente fiduciário, o crer, que, nesse caso, desencadeia o processo de interação patêmica, o modo de conjunção interactancial. Segundo Fontanille (2005, p. $\left.241^{60}\right)$ :

Toda esta série comporta dois pressupostos indispensáveis. A saber:

\footnotetext{
${ }^{60}$ Trecho original: "Toute cette série comporte deux présupposés indispensables. À savoir: 1. Que l'autre soit dans une situation dysphorique: cela implique évidemment une appréciation de sa situation, au plan thymique, voire axiologique; [...]. 2. Que l'autre soit reconnu comme un semblable. [...] éprouver de la compassion ou de la pitié, c'est identifier au moins un trait partagé, qui fera de l'autre un semblable [...].
} 
1. Que o outro esteja em uma situação disfórica: o que implica evidentemente uma apreciação de sua situação, no plano tímico e também axiológico; [...].

2. Que o outro seja reconhecido como um semelhante. [...] experimentar compaixão ou piedade é identificar ao menos um traço compartilhado, que faz do outro um semelhante [...].

Em resumo, para que se configure o estado de alma compassivo ou piedoso, dois "mecanismos" devem atuar na instauração da interação (perceptiva): (i) a interpretação da situação disfórica que se apresenta ao sujeito da percepção; e (ii) o movimento de assemelhação, isto é, de identificação com o sujeito que sofre, seja ela uma identificação plena ou parcial. Ainda nas palavras do autor (Idem, ibid ${ }^{61}$ ), "esta apreciação pode ser puramente participativa (pôr-se no lugar do outro), uma identificação somática e sensível; mas ela pode também ser avaliativa, e é então que a manifestação do julgamento se torna depreciativa (nela entra 'algo de desprezo')".

O sujeito compassivo ou piedoso, ao ser testemunha do sofrimento alheio, e acreditando partilhar os mesmos valores, compadece-se, em um movimento de conjunção, porque crê-saber o que o outro está sofrendo, o efeito causado pelo mal que o assola. Assim, o $\operatorname{crer(-saber),~ao~estabelecer,~na~situação~de~produção~de~tais~}$ efeitos patêmicos, o elo entre o sujeito da percepção e o objeto percebido, apresenta-se como operação juntiva, como o pivô passional de tais interações afetivas. É ele o responsável pelo "despertar" da experiência patêmica, o elemento que, ao marcar um movimento de identificação, de reconhecimento, assinala a competência do sujeito apaixonado para sentir.

Conforme explica Greimas (1983, p. 119²), "o re-conhecimento, ao contrário do conhecimento, é uma operação de comparação daquilo que é 'proposto' [...] e daquilo que já se sabe e/ou se crê". Ele acrescenta (Idem, ibid ${ }^{63}$ ), “fica claro que o 'reconhecimento' é, antes de mais nada, o controle da adequação

${ }^{61}$ Trecho original: "[...] cette appréciation peut être purement participative (se mettre à la place d'autrui), une identification somatique et sensible; mais elle peut aussi être évaluative, et c'est alors que la seule manifestation du jugement devient dépréciative (il y entre 'quelque chose du mépris')."

${ }^{62}$ Trecho original: "Or, la re-connaissance, contrairement à la connaissance, est une opération de comparaison de ce qui lui est 'proposé' [...] et de ce qu'il sait/croire déjà."

${ }^{63}$ Trecho original: "On voit bien que la 'reconnaissance' est tout d'abord le contrôle de l'adéquation du nouveau et de l'inconnu à l'ancien et au connu, et que la vérité ou la fausseté de la proposition soumise au jugement n'en est que l'effet secondaire." 
do novo e do desconhecido ao antigo e ao conhecido, e que a verdade ou falsidade da proposição submetida ao julgamento não passa de seu efeito secundário".

Instaura-se assim a propriedade formal fundante das cenas passionais em questão: o sujeito apaixonado, seja o compassivo, seja o piedoso, concebe, a partir da manifestação do sofrimento de outrem (o parecer), e da comparação consigo mesmo, a imanência (o ser) do padecimento, fundando o imaginário (o crer-saber) que o competencializa para sentir. Esse fazer interpretativo, como operação fundada no reconhecimento (GREIMAS, 1983), é, portanto, o elemento-chave da estruturação patêmica do efeito de compaixão e piedade; ele é o responsável pela patemização que faz do sujeito da percepção um sujeito apaixonado, um sujeito compassivo e/ou piedoso.

Nas palavras, e no contexto teórico, do filósofo Adam Smith (1999, p. 24$25^{64}$ ), essa interpretação se confirma:

[...] nós só podemos formular uma ideia sobre a maneira pela qual eles são afetados quando concebemos o que nós mesmos sentiríamos na mesma situação. [...] É só pela imaginação que nós podemos idealizar quais são as suas sensações. E esta capacidade nos permite representar aquilo que poderiam ser nossas próprias sensações se estivéssemos em seu lugar. [...] Seus padecimentos, quando eles são, então, despertados em nós, quando os adotamos e os fazemos nossos, começam a nos afetar; [...]

A atividade epistêmica, como ato cognitivo que sensibiliza e patemiza a relação interactancial, está, nesse sentido, no cerne desse tipo de interação afetiva. De toda maneira, se há um princípio estruturador comum a ambos os estados de alma - que pode talvez explicar o fato de os estados de alma em causa serem considerados como paixões sinônimas -, o "ser do ser", ou melhor dizendo, o "ser do crer" é, em cada um desses afetos, sobredeterminado, como demonstram os segmentos definicionais descritos anteriormente, por diferentes predicados modais: um querer(-ser) próprio ao sujeito compassivo, e um dever(-ser) para o

\footnotetext{
${ }^{64}$ Trecho original: “[...] nous ne pouvons former une idée de la manière dont ils sont affectés qu'en concevant ce que nous devrions nous-mêmes sentir dans la même situation. [...] Ce n'est que par l'imagination que nous pouvons former une conception de ce que sont ses sensations. Et cette faculté ne peut nous y aider d'aucune autre façon qu'en nous représentant ce que pourraient être nos propres sensations si nous étions à sa place. [...] Ses souffrance, quand elles sont ainsi ramenées en nous, quand nous les avons ainsi adoptées et faites nôtres, commencent enfin à nous affecter; [...]"
} 
piedoso.

Uma possibilidade de elucidar essa distinção entre os modos de conjunção parece estar nas duas relações apontadas por Barros (2001) no trecho a seguir, a juntiva, entre sujeito e objeto, e a de comunicação, de transmissão de valores entre o sujeito (destinatário) e o destinador.

O sujeito do estado é o lugar privilegiado da confluência de duas relações: enquanto sujeito, está em conjunção ou em disjunção com o objeto-valor, enquanto destinatário, papel assumido pelo fato de a junção resultar de um fazer comunicativo, relaciona-se com o destinador. 0 sujeito do estado, por conseguinte, mantém laços afetivos ou passionais com o destinador, que o torna sujeito, e com o objeto, a que está relacionado por conjunção ou por disjunção. (p. 62)

Podemos, assim, inferir que na compaixão, cuja modalidade dominante parece ser o querer, a interação entre sujeito compassivo e objeto-valor do pesar (sujeito sofredor) se faz de forma direta, marcando uma autodestinação, ou seja, uma sincretização dos papéis actanciais de destinador e destinatário na figura do sujeito compassivo; o que explicaria a identificação síncrona própria a uma interação mais sensível, segundo fazem entender os semas levantados a partir da raiz etimológica. Nesse caso, o crer-saber, a operação de comparação, tem natureza tônica e configura uma conjunção realizada - a dor do outro passa a ser a dor do próprio sujeito da percepção.

Já na piedade, que teria o dever como modalidade regente, a relação entre os actantes envolvidos seria pré-determinada pela discretização, na instauração do sujeito piedoso, das funções de destinador e de destinatário (conduta moral e sujeito da percepção, por exemplo). 0 sentir, ou a sensibilização que patemiza a interação piedosa, não surge, dessa forma, do próprio sujeito, mas de uma imposição (social) de comiseração, uma “obrigação", uma "necessidade" - para usar a denominação própria ao dever-ser - que lhe é imposta pelo destinador. Trata-se aqui não de uma interação tônica e sensível, como acontece na compaixão, mas de uma inter-relação sobretudo social, e por isso mesmo, átona e mais inteligível, desencadeando uma conjunção atualizada.

Como determinante do modo de interação afetiva estabelecido em uma 
paixão e outra, o crer-saber dos sujeitos compassivo e piedoso aponta, pois, para distintas maneiras de configuração da competência passional, e, consequentemente, do elo interactancial, do modo de conjunção em cada um dos casos. Estabelece-se, assim, um observador sensível e outro social; e a esse propósito Discini (2011) explica: o observador sensível é, de fato, autocentrado axiológica e afetivamente, enquanto o observador social é aquele que se define segundo um posicionamento pré-determinado socialmente.

Ademais, sobre essa mesma questão Greimas e Fontanille (1993, p. 170) acrescentam: "o observador social [...] moraliza a manifestação passional para reafirmar um estado de coisas em detrimento de um estado de alma"; bem ao contrário do que faz o observador sensível ao privilegiar não o estado de coisas, mas sim o estado de alma depreensível da manifestação passional observada.

0 vínculo afetivo estabelecido entre os sujeitos (sujeito da percepção e sujeito do padecimento, objeto-valor do pesar) é caracterizado, portanto, por um fazer interpretativo, um crer-saber, de natureza qualitativa diferente. Como modalidades de base da configuração do sujeito compassivo e do piedoso, o querer e o dever mostram-se atrelados aos modos de existência do crer e, por conseguinte, do próprio sentir, da junção. De acordo com Fontanille e Zilberberg (2001, p. 255), a crença, concebida como competência, pode mesmo tomar duas formas:

\footnotetext{
A primeira é uma crença que, do ponto de vista do caráter predicativo, será endógena e, do ponto de vista tensivo, de abertura: é a assunção (o sujeito assume sua competência como uma eficiência sentida como que "do interior" ou, de todo modo, com plena "autonomia"); a segunda é uma crença exógena e, do ponto de vista tensivo, de fechamento: é a adesão (o sujeito adere à sua competência como uma eficiência sentida "do exterior"; estamos então diante da heteronomia").
}

O crer-saber da compaixão se coloca, pois, como um crer-saber-assumido pelo sujeito, o que faz entender o querer-ser que o configura e a partilha mesma do sofrimento; já o da piedade apresenta-se como crer-saber-aderido, justificando o dever-ser e a motivação exógena do pesar, o não-poder-não-ser, determinado pelo destinador social.

Aliando as informações levantadas até aqui com aquela classificação 
proposta por nós no capítulo anterior, referente aos quatro modos complexos de interação afetiva de base (fusão, cisão, aproximação e desprendimento), podemos dizer que:

(i) na compaixão, para a qual atua (cf. Tabela 2.8) o crer-saberassumido, a presença do objeto-valor (o padecimento percebido) é tônica, o que explica a maior convocação sensível do sujeito e a plenitude da conjunção afetiva configurada, uma interação realizada, com efeito de fusão entre os actantes envolvidos;

(ii) na piedade, por outro lado, a presença do objeto-valor é (cf. Tabela 2.8) átona, dada a instauração do crer-saber-aderido, próprio à atualização da interação afetiva, a uma relação interactancial regida sobretudo pelo inteligível, que não chega a ser da ordem da fusão, assinalando apenas uma aproximação entre os sujeitos, uma não-disjunção.

\begin{tabular}{|c|c|c|}
\hline COMPAIXÃo & PIEDADE \\
\hline $\begin{array}{c}\text { Modo de presença do } \\
\text { objeto-valor da } \\
\text { afetividade }\end{array}$ & $\begin{array}{c}\text { maior densidade de presença } \\
\text { do objeto-valor do pesar }\end{array}$ & $\begin{array}{c}\text { menor densidade de presença } \\
\text { do objeto-valor do pesar }\end{array}$ \\
\hline $\begin{array}{c}\text { Modo de convocação do } \\
\text { sensível e do inteligível }\end{array}$ & $\begin{array}{c}\text { maior impacto sensível, } \\
\text { menor processamento } \\
\text { inteligível }\end{array}$ & $\begin{array}{c}\text { menor impacto sensível, } \\
\text { maior processamento } \\
\text { inteligível }\end{array}$ \\
\hline $\begin{array}{c}\text { Modo de existência } \\
\text { do pivô passional }\end{array}$ & $\begin{array}{c}\text { crer-saber assumido } \\
\text { (querer) }\end{array}$ & $\begin{array}{c}\text { crer-saber aderido } \\
\text { (dever) }\end{array}$ \\
\hline $\begin{array}{c}\text { Modo de junção } \\
\text { conjunção }\end{array}$ & $\begin{array}{c}\text { não-disjunção } \\
\text { (interação afetiva realizada) }\end{array}$ & (interação afetiva atualizada) \\
\hline $\begin{array}{c}\text { Modo de interação } \\
\text { afetiva instaurado }\end{array}$ & fusão & aproximação \\
\hline
\end{tabular}

Tabela 2.8: Tabela comparativa das propriedades formais de compaixão e piedade. 
A natureza do sentir "despertado" pelo crer-saber da compaixão se caracteriza, nesse sentido, por uma intensidade tônica, advinda do campo de (co)presença, que, com o máximo de convocação sensível, une, de fato, por fusão, o sujeito da percepção e o objeto-valor percebido. Já no caso do sentir próprio à piedade, subjaz uma intensidade átona, que, resultando em um menor impacto sensível, logo, maior assimilação inteligível, delineia uma interação afetiva de aproximação simplesmente.

Além disso, o querer, resultante do crer-saber-assumido e da interação afetiva realizada, é modalidade endotáxica, isto é, liga enunciados que têm sujeitos idênticos ou em sincretismo, corroborando a ideia de uma simetria de lugares: o sujeito compassivo em conjunção com o padecimento do sujeito sofredor, o objetovalor percebido. 0 dever, por sua vez, relacionado ao crer-saber-aderido, de afetividade atualizada, é modalidade exotáxica, ligando enunciados que têm sujeitos distintos e definindo uma assimetria de lugares, não por disjunção, que implicaria cisão interactancial, mas por uma não-disjunção, uma aproximação do sujeito piedoso em relação ao objeto-valor do pesar.

Querer e dever, ao se instituir como qualificação e condição próprias ao "ser do ser", ou seja, ao "ser do crer", mostram-se, assim, como modalidades dominantes na configuração do "ser do sentir", da natureza do pesar compassivo e/ou piedoso, determinando a distinção entre o modo como o sujeito interage e se relaciona afetivamente com o objeto-valor percebido, o padecimento alheio, em cada um dos casos. Na compaixão esse modo de interação afetiva, regido por uma lógica volitiva (querer-ser), explica a espontaneidade do compadecimento desencadeado como um "impulso"; na piedade, para a qual domina a lógica alética (dever-ser), o pesar está mais próximo, conforme vimos, a uma necessidade, e por isso mesmo se apresenta como uma "virtude".

Todas essas propriedades sintáxicas destacadas justificam o fato de a compaixão configurar-se como um "sentir com" e a piedade como um "sentir por", mas elas dizem muito pouco a propósito das circunstâncias nas quais o pivô passional, o crer-saber, delineia-se como um crer-saber-assumido ou como crersaber-aderido. 0 que condiciona a incitação de um em detrimento do outro? 0 que 
define a interação como sendo da ordem da fusão ou da aproximação, e não da cisão ou do desprendimento, por exemplo?

Pensando que "a paixão não é concebível sem o valor: valor investido nos objetos, axiologias descritivas, obviamente, mas sobretudo valores modais e aspectuais, controlados pelas valências tensivas" (FONTANILLE; ZILBERBERG, 2001, p. 313), e tomando por base o que foi discutido no capítulo anterior, acreditamos que a resposta a essas questões está nas condições de instauração do campo de presença (fase da disposição, segundo a reformulação do esquema passional canônico por nós proposta) no qual se sustenta a interação perceptiva e o modo de acesso aos valores atualizados (fase da patemização), ou seja, valores investidos no objeto da afetividade.

Saímos, então, do horizonte das modalizações (fase da moralização, segundo essa nova perspectiva do esquema passional canônico) para entrar no das modulações, que antecedem as modalidades e as patemizam; ou, conforme sustentam Fontanille e Zilberberg (2001, p. 234), passamos a uma assimilação da "modalização como modulação dos efeitos intencionais associados ao estabelecimento de uma dêixis perceptiva; como regulação da comunicação interactancial”, com as peculiaridades da junção convertidas em determinações tensivas.

A modalização é, então, remetida ao campo de percepção do sujeito, com os modos de presença do objeto-valor do afeto intimamente relacionados às condições de base na produção do estado de alma, na articulação do sensível com o inteligível; são eles, como veremos, que regulam e gerenciam esta última.

\subsubsection{Da modalidade à modulação: os parâmetros tensivos}

Para melhor compreender as peculiaridades sintáxicas que determinam a identidade modal do sujeito tomado de compaixão ou piedade - o querer-ser e o dever-ser, respectivamente -, daremos continuidade à exploração das circunstâncias de geração do crer-saber-assumido e do crer-saber-aderido, 
procurando depreender as modulações tensivo-fóricas organizadoras do campo de presença (fase da disposição), considerado como domínio espaço-temporal no qual se exerce a percepção e consequentemente a interação (sensível-inteligível) entre o sujeito e o objeto-valor da afetividade provocada (fase da patemização).

Tendo como ponto de partida o fato de as primeiras articulações prefiguradoras das modulações serem da ordem da intensidade e da extensidade da atividade perceptiva, buscaremos, de início, determinar o modo de atuação desses dois demarcadores do campo de presença. Isso nos permitirá apreender o estilo tensivo (contensivo, extensivo, retensivo e distensivo) próprio à interação compassiva ou piedosa, uma vez que, conforme pontuam Fontanille e Zilberberg (2001, p. 307), “o 'estilo tensivo’ de uma paixão é um esquema cujo perfil seria diretamente calculável a partir das mudanças no equilíbrio e na direção da correlação entre a intensidade e a extensidade passionais".

Para que a interpretação patemizante, isto é, o julgamento epistêmico do compassivo ou do piedoso tenha lugar, é preciso haver, como vimos, uma copresença, uma interação antes de mais nada perceptiva entre o sujeito da percepção e o objeto-valor do pesar (fase da constituição); e o estabelecimento dessa inter-relação põe em causa dois pressupostos de base: (i) a maneira pela qual emergem os valores que caracterizam a cena instituída no campo perceptivo do sujeito, responsável pela convocação de sua sensibilidade e inteligibilidade, e (ii) o modo como se constitui a partir daí a presença do objeto-valor da afetividade (fase da sensibilização, englobando as etapas da disposição e da patemização).

Assim, iniciaremos essa segunda etapa da análise buscando identificar as especificidades da profundidade que caracteriza o campo de presença próprio aos estados de alma de compaixão e piedade. Esta noção é entendida aqui, tal como a concebe a perspectiva tensiva, como resultado da tensão estabelecida entre um centro dêitico, o sujeito da percepção, e os seus horizontes, definidos pela intensidade e extensidade da presença instaurada no campo de coexistência (fase da disposição). Como lembra Lopes (2006, p. 11, grifo nosso):

A profundidade proposta é medida pelas correlações entre intensidade e extensidade identificáveis nesse campo posicional. Em princípio, quanto mais distante do centro dêitico (maior 
extensidade), menor a intensidade sensível - sensível significando, no caso, "perceptiva" e "tímica" simultaneamente; quanto mais próximo do centro dêitico (menor extensidade), maior o impacto sensível, logo a intensidade.

Assim, se a compaixão é, como vimos, prescrita por uma interação de maior sensibilidade, na qual o sujeito da percepção e o objeto-valor do pesar chegam a se fundir, o campo de presença estabelecido deve ter profundidade compacta, fazendo com que os valores investidos no objeto da percepção apareçam para o sujeito de modo acelerado e tônico, fortalecendo a sincronização sensível, mas inibindo o tempo de processamento inteligível da presença; ao passo que na piedade, cujos interactantes mantêm-se em relação assimétrica, sem grande convocação estésica, o espaço de co-presença deve, por sua vez, ter maior profundidade, permitindo aos valores uma emersão um pouco menos acelerada e com menor tonicidade, enfraquecendo, por conseguinte, a convocação sensível, o que favorece, por outro lado, a possibilidade de maior assimilação inteligível da presença.

Conforme explicam Fontanille e Zilberberg (2001, p. 148):

Se o emissor for tônico, sua ação aparecerá como um golpe, e produzirá no receptor um "efeito"; se o emissor for átono, sua ação aparecerá apenas como "eficiência", e o receptor contentar-se-á em senti-la como "presença". Para o observador, o "efeito" e a "presença" manifestam, pois, respectivamente, a "ação" e a "eficiência" do emissor.

Essas determinações da profundidade do campo de presença próprio à compaixão e à piedade conferem e explicam, mais uma vez, a questão da competência passional assentada no "sentir com" (emoção intensa, tônica, que gera a unidade, a fusão) por parte do compassivo, e no "sentir por" (emoção distribuída e, por isso, átona, marcando a não-conjunção, o interesse) para o piedoso. Os autores citados acrescentam (2001, p. 142):

A realização do sujeito $S$, em face de um mundo $M$ percebido como único e de presença compactada, consagra-o como contraído, unificado, na medida em que não há qualquer distância entre o foco [apreensão local] ${ }^{65} \mathrm{e}$ a apreensão [apreensão global], entre a

\footnotetext{
${ }^{65}$ Para evitar qualquer confusão com os termos foco e apreensão - visée e saisie, no original em
} francês, também traduzidos, em outras obras, como: visada e apreensão; focalização e apreensão -, 
interoceptividade e a proprioceptividade: a apropriação do mundo $M$ pelo sujeito $S$ é, de certa maneira, simultânea à sua confrontação.

[...]

A atualização defronta o sujeito $\mathrm{S}$ e um mundo $\mathrm{M}$ percebido como concentrado e massivo: assim, ela reconstitui em parte a tensão entre as duas instâncias S' [sujeito da apreensão local] e S" [sujeito da apreensão global], e permite, se não uma sincronização, pelo menos uma superposição parcial de seus atos e papéis respectivos, de modo que o sujeito poderá ser chamado aqui de mobilizado [...].

O devir característico ao sentir que instaura, na fase da moralização, o sujeito compassivo configura-se, portanto, pela presença viva, tônica, do objetovalor da afetividade, em um campo de presença circunscrito que, desfavorecendo os entornos, esclarece a ligação mais intensa, a maior tensão na relação interactancial, e, por conseguinte, o impacto superior sobre o sujeito da percepção, fazendo com que o crer-saber responsável pelo despertar da afetividade seja um crer-saber-assumido, típico à interação afetiva realizada. Os valores investidos no objeto-valor ao qual a afetividade é direcionada são sentidos, dessa forma, como sendo do próprio sujeito da percepção; daí a assunção a um ponto de vista mais individualizado, próprio aos valores de absoluto.

No caso do piedoso, o devir fruto da presença atualizada ata a tensão interativa ao fracionamento da atividade perceptiva ampliada aos entornos, apontando, simultaneamente, para um grau menor de tonicidade perceptiva, e para o aumento de atuação do inteligível na produção do pesar. Os valores investidos no objeto-valor do compadecimento, misturados àqueles que caracterizam os entornos, são, dessa forma, apreendidos como exteriores, reconhecidos pelo sujeito da percepção, mas como pertencentes à situação do sujeito sofredor; o que explica a menor simetria de lugares estabelecida entre eles e a adesão a um ponto de vista menos individual, menos próximo aos valores de absoluto.

Segundo os autores de Tensão e significação (2001), o modo de existência realizado, na perspectiva da intensidade, é mesmo compacto e, na da extensidade,

adotados por Fontanille e Zilberberg em Tensão e significação (2001), e que foram completamente reformulados nas obras posteriores de Zilberberg, decidimos optar, sem prejuízo da ideia inicialmente concebida no referido livro, pelos termos apreensão local para foco, e apreensão global para apreensão. 
uno e singular (conf. Esquema 2.1), o que retrata o estilo contensivo da relação de conjunção entre sujeito apaixonado e objeto da paixão. Já o modo atualizado tem intensidade concentrada, mas extensidade massiva (conf. Esquema 2.1), resultando em um estilo contensivo, uma não-disjunção interativa.

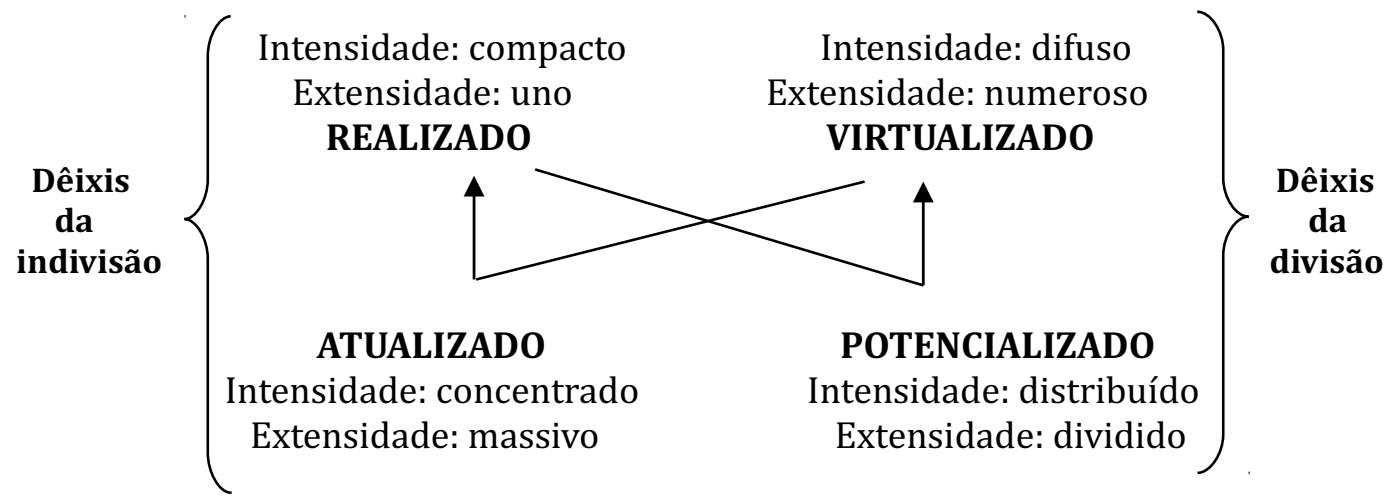

Esquema 2.1: Regimes de intensidade e extensidade (cf. FONTANILLE, ZILBERBERG, 2001, p. 136)

Eles assinalam ainda (2001, p. 126): "quando a profundidade se projeta na competência do sujeito da percepção, ela dá lugar à dialética dos 'pontos de vista': aos intervalos inerentes à distância correspondem morfologias perceptivas, ora apenas distintas, ora irredutíveis umas às outras [...]". É, nesse sentido, a modulação tensiva, própria aos estados de alma em questão, que, ao sobredeterminar o modo de presença e a circulação dos valores investidos no objeto da afetividade, delineia diferentes modos de o perceber e, consequentemente, de com ele interagir.

A distinção entre o compassivo e o piedoso não está, por conseguinte, necessariamente no grau de intensidade do sentir (manifestado), mas, sobretudo, na variação da tonicidade perceptiva da presença (manifestante) quando da coexistência com o sujeito da percepção. As especificidades sintáxicas dos modos de interação afetiva examinados remetem, pois, a um ponto de vista totalmente localizado por parte do sujeito compassivo, típico à apreensão local (foco ${ }^{66}$ ), na qual, conforme explicam Fontanille e Zilberberg (2001, p. 130), “a intensidade e a extensidade perceptivas evoluem de maneira inversa: quanto menos objetos se

${ }^{66}$ Reiteramos: os termos apreensão local e apreensão global estão sendo usados segundo a definição de foco e apreensão, respectivamente, apresentada em Tensão e significação (2001), e foram adotados para evitar uma confusão com os sentidos que lhes seram atribuídos nas obras posteriores de Claude Zilberberg. 
visam de uma só vez, mais bem estes são visados", e a um outro mais globalizado no caso do piedoso, característico a uma apreensão global, "que procede por delimitação de uma extensão, demarcando o domínio para aí circunscrever o objeto" (Idem, ibid).

No primeiro caso, o efeito de compaixão, se associado à operação de triagem axiológica, aos valores de absoluto, firma-se no tipo perceptivo da apreensão local, ou seja, o máximo de intensidade está vinculado à unicidade do objeto-valor do pesar, a uma grandeza caracterizada pela alta tonicidade perceptiva do valor nela investido e sua consequente exclusividade no campo de presença do sujeito compassivo, com a interação afetiva desencadeada sendo marcada por uma maior homogeneidade interactancial. No segundo, por sua vez, o efeito de piedade, atrelado não necessariamente aos valores de absoluto, parece estar relacionado à operação de mistura e totalização axiológica, instituindo-se na apreensão global, mais próxima aos valores de universo. Embora se configure certa intensidade, a extensidade massiva multiplica os valores apreendidos no ato perceptivo, desestabilizando a homogeneidade, a simetria entre os actantes envolvidos.

Assim, se apreender de maneira local é focalizar, selecionar, triar em uma extensão aberta a zona em que se exercerá a percepção mais intensa, renunciando ao número dos elementos apreendidos em prol da saliência perceptivas de alguns, ou de um único (FONTANILLE; ZILBERBERG, 2001), nossa hipótese é a de que o estado de alma de compaixão se instaura quando a percepção do sujeito apaixonado recai exclusivamente sobre o sofredor, o objeto-valor do pesar suscitado, ou melhor, sobre a manifestação explícita do padecimento deste último, quando não o desespero vivido e demonstrado por ele, o qual concentraria os valores em jogo e, consequentemente, a tensão, a intensidade que convoca e afeta o sujeito, justificando a sua maior incitação sensível, a configuração do crer-saberassumido.

O efeito patêmico de piedade, por outro lado, surgiria a partir de uma apreensão que privilegia não apenas o sofrimento do outro em si, mas também o "mal causador", a situação que faz ser o padecimento, com os valores caracterizados na extensão do domínio espacial do ato perceptivo. Nesse caso, a 
dor do outro vem para o sujeito da percepção por meio de catálise, como inferência feita a partir do espaço percorrido. A extensão da composição figurativa do objetovalor do pesar, ao incluir o entorno, comprometeria a apropriação, a assimilação síncrona e o partilhar entre os sujeitos, distendendo também o sentir correspondente à tensão interactancial. Com a atenção voltada aos entornos, e não só ao sujeito que é por ele afetado, o sofrimento é deduzido; daí a sensibilização, o pesar gerado, ter natureza mais inteligível - crer-saber-aderido -, com menor convocação estésica.

Essa nossa interpretação é diferente daquela proposta por Fontanille (2003, 2005, 2006), quando ele assinala, a partir das considerações de Heidegger sobre a "preocupação mútua", a diferença entre compaixão e piedade como sendo da ordem de traços aspecto-temporais. Para o semioticista citado, "a gama passional se diversifica e se define segundo privilegiemos, na existência do outro, o seu devir, a sua situação ou o seu destino" (FONTANILLE, 2005, p. $246^{67}$ ). Ele explica (Idem, p. $\left.244^{68}\right)$ :

A compaixão, em suma, pode ser potencial, sem atualização imediata, e funcionar como uma disposição sempre voltada para as situações por vir, tanto quanto para as situações presentes. A piedade, ao contrário, é obrigatoriamente atualizada, e só surge a partir de um acontecimento atestado ou uma situação presente, ou mesmo já instalada anteriormente.

Em resumo, podemos experimentar compaixão por tudo aquilo que aguarda o outro nesse "vale de lágrimas" que é o nosso mundo, sem por isso sentir dele piedade; se mesmo assim sentíssemos piedade, seria à custa de um considerável esforço de atualização imaginária do porvir, ou mesmo em nome de algum fatalismo que considerasse o não-consumado (no mundo concreto) como já advindo (no mundo traçado do destino). Da

\footnotetext{
${ }^{67}$ Trecho original: "La gamme passionnelle se diversifie et se définit donc, selon que l'on vise dans l'existence d'autrui son devenir, sa situation ou sa destinée."

${ }^{68}$ Trecho original: "La compassion, en somme, peut être potentielle, sans actualité immédiate, et fonctionner comme une disposition toujours tendue vers les situations à-venir, tout autant que vers les situations présentes. La pitié, en revanche, est obligatoirement actualisée, et n'apparaît qu'en relation avec un événement attesté ou une situation présente, voire déjà installée antérieurement. En somme, on peut bien éprouver de la compassion pour tout ce qui attend l'autre dans cette "vallée de larmes" qu'est notre monde, sans pour autant éprouver pour lui de la pitié; si même on éprouvait en ce cas de la pitié, ce serait au prix d'un considérable effort d'actualisation imaginaire de l'à-venir, ou même au nom de quelque fatalisme qui considérerait le non-accompli (dans le monde concret) comme déjà advenu (dans le monde écrit du destin). De la compassion à la pitié, il se produit donc une réduction des situations possibles à une situation-occurence réalisée. La compassion porte sur le "pouvoir être", à la différence de la pitié qui ne peut porter que sur un état actuel."
} 
compaixão à piedade, produz-se, então, uma redução das situações possíveis a uma situação-ocorrência realizada. A compaixão recai sobre o "poder ser", diferentemente da piedade que só pode incidir sobre um estado atual.

Se é mais apropriado pensar a diferença entre compaixão e piedade a partir da temporalidade das situações em causa, ou a partir do modo de presença do objeto-valor do pesar no campo de presença que se cria entre os interactantes, com o acento de sentido recaindo, em um dos casos, exclusivamente sobre o sofrimento experimentado, ou, na outra possibilidade, também sobre o "mal causador", isso poderá ser avaliado no capítulo seguinte, no qual examinaremos ambos os estados de alma in vivo, isto é, a partir do discurso em ato.

Sabemos que a hipótese lançada por nós só pode ser confirmada através de uma análise que tenha as interações patêmicas examinadas in praesentia, isto é, manifestadas. De qualquer maneira, parece estar claro que as condições de emergência do sentir do compassivo e do piedoso estariam ligadas, prioritariamente, às diferentes formas pelas quais os valores investem $\mathrm{e}$ estruturam o campo de presença do sujeito sensível em uma paixão e outra, apontando para as operações de base perceptiva que aparecem associadas à articulação do sensível com o inteligível, definindo, dessa forma, diferentes estilos de valoração do objeto, tanto no nível figurativo (manifestante) quanto no nível figural (manifestado), como veremos nas análises a seguir.

\subsection{Considerações gerais sobre a análise lexical}

A partir dos elementos semânticos levantados pela investigação das definições, procuramos compreender, pelo menos de duas maneiras, a configuração subjacente aos estados de alma de compaixão e piedade: (i) no que diz respeito à identidade modal da relação entre os sujeitos compassivo e piedoso, e (ii) naquilo que tange às condições de emergência dos afetos em questão, às modulações tensivas que gerenciam o ato perceptivo e instauram a interação. A ideia, como foi mencionado no início deste capítulo, era a de examinar a existência 
de semelhanças e possíveis diferenças na configuração sintáxica desses efeitos passionais, levantando elementos para defender a distinção entre eles. Além disso, tínhamos também a intenção de verificar, através dos dados apreendidos, a coerência das determinações sintáxicas subjacentes à tipologia de base dos modos complexos de interação afetiva proposta no capítulo anterior.

Na perspectiva das modalizações existenciais, as modalidades regentes da identidade do compassivo e do piedoso, querer-ser e dever-ser respectivamente, definem, por meio de sua incidência sobre a junção, as especificidades da polêmica contratual que subjaz aos modos de interação afetiva entre o sujeito da percepção e o objeto-valor percebido em um caso e outro, apontando para uma diferença significativa de estruturação do pivô passional (o crer-saber a dor alheia) de ambos os estados de alma, e não só em termos sintáxicos, mas também semânticos.

Enquanto valores modais, o querer e o dever se apresentaram como os elementos regentes das axiologias envolvidas em tais núcleos patêmicos, com a interação compassiva dirigida por um ponto de vista mais individualizado (valores de absoluto), procedente do íntimo humano, próprio a uma sanção passional de caráter endógeno, isto é, fruto da sincretização actancial dos papéis de destinador e destinatário na figura do compassivo, e a piedosa, por um ponto de vista um pouco mais generalizante (mais próximo aos valores de universo), relacionado aos deveres sociais, morais e religiosos, com uma sanção de ordem exógena, ou seja, advinda da discretização actancial das funções de destinador e destinatário no ator piedoso. Isso explica o efeito de espontaneidade, de origem natural e instintiva do "sentir com" na compaixão, e o efeito de maior racionalidade, de determinação sóciocultural do "sentir por" na piedade.

Ao se constituir como operadores da modalização da junção (do modo de conjunção, uma vez que ambas são paixões de conjunção), da relação intersubjetiva estabelecida entre os sujeitos envolvidos, ou, mais especificamente, a propósito das funções actanciais, entre o sujeito da percepção e objeto-valor da afetividade, do pesar, querer e dever apontaram para as peculiaridades da configuração do crersaber, instaurado como assumido, no caso da compaixão, e aderido, no da piedade. Foi então que se evidenciou a necessidade de um exame "aquém" da identidade 
modal do compassivo e do piedoso, voltada às condições de emergência das interações examinadas. Afinal, conforme destacam Fontanille e Zilberberg (2001, p. 309), "os dispositivos em questão não são pois sequências que acumulam apenas conteúdos modais (enfim, 'sequências' modais), mas configurações cuja sintaxe interna é assegurada pelo jogo das correlações tensivas".

As diferenças qualitativas do pivô passional, o crer-saber que fundamenta o compadecimento sentido ante o sofrimento de outrem, bem como do modo de conjunção, mostraram poder ser, de fato, produto da maneira pela qual o objeto da afetividade suscitada é apreendido na atividade perceptiva, exercida em um espaço tensivo de co-existência no qual a inserção dos valores se faz de forma diversificada, provocando modos de interação afetiva distintos.

Na compaixão, a inter-relação (patêmica) se estabeleceria em um campo de presença de profundidade mínima, colocando o acento de sentido, segundo cremos, diretamente no objeto da afetividade; o que abrevia o processo interpretativo subjacente ao crer-saber a dor do outro, acelerando a inserção dos valores a ele relacionados. Isso explica a maior convocação sensível do sujeito da percepção e a menor possibilidade de assimilação inteligível da presença, tal como é típico a um estado de alma da ordem da fusão.

Na piedade, ao contrário, nossa hipótese é a de que é maior a distância entre o centro da atividade perceptiva e o objeto-valor do pesar, concentrando a intensidade em uma extensão mais ampla, na qual se inclui o entorno que caracteriza o sofrimento. Essa expansão do campo de atuação da sanção desacelera a emergência dos valores investidos no objeto, diminuindo a sua força de impacto e com ela a convocação sensível, o que permite um processamento mais inteligível da presença com a qual a interação afetiva se estabelece, tal como se verifica nos estados de alma instituídos pela aproximação.

Logo, embora haja nos dois casos uma sensibilização operada pela intensidade da situação disfórica vivida, é distinta a maneira pela qual ela se imprime na presença: fechando os horizontes do campo de interação, o que recrudesce a sua força de impacto, o seu poder de convocação sensível; ou abrindoo, e, então, restabelecendo a atuação da assimilação inteligível. Há, dessa forma, 
comoção tanto na compaixão quanto na piedade; varia, no entanto, o seu grau de atuação na configuração do "valor do valor", da sanção intersubjetiva formulada pelo sujeito da percepção.

Parece ser, com efeito, conforme sugerimos no capítulo anterior, dedicado às novas proposições teórico-metodológicas para o estudo das paixões na perspectiva semiótica, e como demonstrou essa primeira análise realizada, o modo de perceber o objeto da afetividade, ou, mais especificamente, o modo de apreensão dos valores nele inscritos, o responsável pelas condições de produção do "valor do valor", e, por conseguinte, das características típicas a determinado modo de interagir, de se relacionar (afetivamente) com o que representa o outro.

A tipologia proposta no capítulo anterior mostra, acreditamos, a sua coerência e validade para a análise das circunstâncias de geração dos afetos. De toda forma, é preciso ainda verificar como essa sintaxe subjacente aos efeitos de compaixão e piedade se comporta no discurso em ato, na "interação viva" com uma presença específica, porque discursivizada, inserida no campo perceptivo do sujeito da percepção que virá a ser compassivo ou piedoso. 
Capítulo 3

Entre enunciação e enunciado: a configuração do efeito passional em ato 
[...] l'art est le produit d'une émotion particulière - quelle que soit sa nature - que l'artiste désire communiquer; et l'écrivain le plus ambitieux, le moins soucieux de plaire, ne renonce pas à seduire, fût-ce par les voies détournées du déplaisir. [...] l'écrivain sollicite non seulement la bienveillante attention de ce lecteur qu'il affecte de négliger, mais son intérêt, son admiration, voire son affection [...]

G. Mathieu-Castellani

\subsection{Notas preliminares sobre a análise do corpus}

Uma vez expostas nossa reflexão, proposta e hipótese sobre alguns tópicos teóricos e metodológicos próprios ao estudo das paixões dentro da perspectiva semiótica de linha francesa, a análise lexical serviu tanto para uma primeira avaliação das proposições apresentadas, quanto para a depreensão da estrutura (sintáxica) elementar subjacente à configuração dos estados de alma de compaixão e de piedade, permitindo a identificação de um perfil tensivo próprio às interações predominantemente sensíveis (como é o caso da compaixão) ou mais inteligíveis (conforme parece acontecer na piedade). A ideia agora é, portanto, verificar, através do exame dos efeitos de sentido sensíveis produzidos nos textos, se as circunstâncias de geração desses pressupostos estruturais - levantadas hipoteticamente no capítulo anterior - confirmam-se. Além disso, conforme salientam Greimas e Fontanille (1993, p. 100), “o corpus lexicográfico e o corpus literário constituem ponto de partida para eventuais generalizações e para suscitar novas interrogações a serem integradas progressivamente às primeiras hipóteses teóricas".

Assim, ao optar pela perspectiva do discurso em ato, concebendo a paixão como resultado da relação perceptiva entre o sujeito e o valor investido no objeto da afetividade, analisaremos os enunciados enquanto campo de presença, isto é, como domínio espaço-temporal no qual se constitui a coexistência do sujeito da percepção, o leitor, e do objeto-valor percebido, o enunciado. Interessa compreender a tensão que, no momento da leitura, determina a convocação e a 
articulação do sensível e do inteligível, bem como a consequente configuração de certo modo de interação afetiva entre o enunciatário-leitor e os atores do enunciado. Assumindo as palavras de Fontanille (1999, p. 73-74 ${ }^{69}$ ):

Precisemos, então, essa concepção de discurso:

um campo de presença, organizado a partir de um corpo próprio, centro da enunciação, e dirigido por movimentos orientados, mais ou menos numerosos e mais ou menos rapidos, que fazem aparecer, desaparecer e que modificam os valores,

Esta definição comporta um certo número de propriedades - o corpo, centro do campo; a orientação discursiva; a presença; o andamento dos movimentos perceptivos - que concernem aos efeitos afetivos. De fato, todas as formas da dimensão afetiva do discurso [...] correspondem ao menos a uma das propriedades de base do discurso; é nesse sentido que podemos dizer que essas propriedades participam do controle discursivo da paixão.

Partindo, pois, do ponto de vista da produção dos efeitos passionais no ato da leitura, o enunciatário-leitor ocupará, em nossa investigação, o papel de sujeito perceptivo, centro do campo de coexistência, enquanto os atores do enunciado, as personagens, sobre os quais, de uma maneira ou outra, sempre recai o núcleo patêmico do discurso, o de objeto-valor da afetividade. Em posição de coenunciador, dada a sua influência direta sobre as escolhas, seleções e organizações operadas pela instância produtora do enunciado, a participação ativa do enunciatário no processo de significação, a partir do contato com o texto, é, segundo pretendemos demonstrar, também passível de ser depreendida discursivamente, ajudando a compreender de maneira mais ampla a configuração da intersubjetividade que faz surgir as paixões no instante do contato, da interação com o enunciado.

Caminhando, pois, em direção ao que pode vir a ser uma semiótica da leitura - atividade própria ao discurso em ato - a intenção é também a de lançar

69 Trecho original: "Précisons ainsi cette conception du discours: un champ de présence, organisé autour d'un corps propre, centre d'énonciation, et traversé par des mouvements orientés, plus ou moins nombreux et plus ou moins rapides, qui font apparaître, disparaître et qui modifient les valeurs. Cette définition comporte un certain nombre de proprietés - le corps, centre du champ; l'orientation discursive; la présence; le tempo des mouvements perceptifs - qui concernent les effets affectifs. En effet, toutes les formes de la dimension affective du discours [...] correspondent à au moins une des propriétés de base du discours; c'est en ce sens qu'on peut dire que ces propriétés participent au contrôle discursif de la passion." 
luz não sobre a atividade perceptiva e subjetiva do enunciador, como é o mais comum nos estudos sobre a enunciação passional, mas sim sobre a do enunciatário, que longe de figurar como ser passivo, apenas recebendo e acatando as informações produzidas pelo enunciador, é, sobretudo, como ente social dotado de saber enciclopédico (repertório sócio-cultural), um interpretante, o páthos do discurso, respondendo tímica e cognitivamente aos valores, aos sentidos que lhe são impostos. Segundo corrobora Jouve (2001, p. $39^{70}$ ):

É sobre o duplo plano emocional e intelectual que o sujeito se implica no universo literário.

0 leitor tem assim uma parte ativa na criação das personagens: ele está ausente no mundo representado, mas presente no texto - e mesmo fortemente presente - enquanto consciência que percebe. Ele representa, para as figuras romanescas, o papel de testemunha e adjuvante.

O enunciatário-leitor será concebido, então, como simulacro construído e depreensível a partir do próprio enunciado, sem qualquer vínculo com uma existência "real", com o leitor de carne e osso; ou seja, ele será estudado a partir das estratégias enunciativas que estruturam o discurso e caracterizam uma imagem de enunciatário, um "leitor-modelo" - para usar o termo adotado por Umberto Eco em seus estudos sobre o assunto $(1962,1979,1990,1992)$.

Fundar a análise na enunciação, enquanto práxis enunciativa, a partir do processo de leitura, do discurso em ato, interessa, além disso, porque permite examinar as condições de emergência dos valores; e, por conseguinte, de convocação do sensível e do inteligível nos estados de alma produzidos, avaliando a coerência do pensamento e do modelo de análise que estamos propondo: o esquema passional canônico tensivizado.

Assim, as narrativas serão examinadas a partir:

(i) das circunstâncias de instauração do campo de presença estabelecido entre enunciatário-leitor e atores do enunciado,

70 Trecho original: “C'est sur le double plan émotionnel et intellectuel que le sujet s'implique dans l'univers littéraire. Le lecteur a ainsi une part active dans la création des personnages: il est absent du monde représenté, mais présent dans le texte - et même fortement présent - en tant que conscience percevante. Il joue, pour les figures romanesques, le rôle de témoin et d'adjuvant." 
ligadas à problemática do ponto de vista - fase da constituição -, uma vez que, conforme explica Fontanille (1999, p. 48 ${ }^{71}$ ), "no ponto de vista, sujeito e objeto estão em interação, e influem, mutuamente, um sobre o outro";

(ii) da predicação tensiva adotada, referente às estratégias de distribuição da tensão, de gerenciamento da atividade perceptiva do sujeito-leitor - fase da sensibilização - através: (iia) da organização espaço-temporal (fase da disposição); (iib) da disposição dos acentos de sentido (fase da patemização); e, então, (iic) da força de impacto dos efeitos passionais suscitados (fase da emoção);

(iii) da configuração do "valor do valor", base do afeto (fase da moralização);

Com interesse na investigação das condições de emergência dos estados de alma de compaixão e piedade, o critério de escolha das narrativas integrantes do corpus desta pesquisa foi exatamente a carga emocional criada e a sua possibilidade de provocar no enunciatário-leitor uma interação afetiva assentada no "sentir com" ou no "sentir por". Além disso, optamos por trabalhar com diferentes autores para que os resultados finais pudessem testar o "caráter geral" das proposições anteriormente levantadas, evitando apenas a identificação com certo estilo autoral de sensibilização nos textos. Dessa forma, entre os enunciados escolhidos para análise, encontram-se:

(i) duas narrativas de Guimarães Rosa - "Conversa de bois", de Sagarana (194672), e “Campo geral”, de Manuelzão e Miguilim (1964) - que, dada a semelhança temática e mesmo figurativa, serão analisadas juntas, de maneira comparativa;

71 Trecho original: "[...] dans le point de vue, le sujet et l'objet sont en interaction, et influent mutuellement l'un sur l'autre."

72 Ano da primeira publicação. 
(ii) um conto de Monteiro Lobato - "Negrinha", do livro de mesmo nome, Negrinha (1920) - que não apenas suscita no enunciatárioleitor o sentimento de pesar pela personagem, mas o apresenta, no extremo oposto, como um dos temas tratados no enunciado;

(iii) um conto de Graciliano Ramos - "Baleia", integrado ao livro Vidas Secas (1938) - cuja temática tem forte apelo à sensibilidade e à afetividade do enunciatário-leitor.

0 primeiro conto, “Conversa de bois" (ver Anexos, p. 225), narra a trajetória de um carro de bois guiado pelo menino Tiãozinho, "um pedaço de gente, com a vara comprida no ombro, com o chapéu de palha furado, as calças arregaçadas, e a camisa grossa de riscado, aberta no peito e excedendo atrás em fraldas esvoaçantes" (ROSA, 2001, p. 327), que vinha triste, trazendo junto ao carregamento de rapaduras o corpo de seu pai, falecido naquela manhã, para ser enterrado no cemitério do arraial. Durante a viagem, vamos tomando conhecimento dos fatos, do padecimento e das angústias do menino através de seus pensamentos, suas lembranças, enquanto os bois conversam e contam causos, e o carreiro Agenor Soronho, "homenzão ruivo, de mãos sardentas, muito malencarado" (p. 328), insensível ao sofrimento de Tiãozinho, ralha o todo ralhando com ele. São, todavia, as passagens em que figuram a interioridade do garoto as de maior interesse para nossa análise, por ser principalmente elas as responsáveis pela interação afetiva entre o enunciatário e o pequeno guia.

A outra narrativa rosiana mencionada, "Campo geral" (ver Anexos, p. 227), conta, por sua vez, a história de um menino de oito anos que morava com a sua família e agregados no Mutum, no meio dos campos gerais. Para nosso estudo importa, sobretudo, o trecho referente à morte de Dito, irmão dileto da personagem central, Miguilim, por se configurar como pico de intensidade máxima de todo o enunciado e, consequentemente, da interação entre ele e o enunciatárioleitor. Ao longo da história vamos percebendo que os dois irmãos eram muito próximos. Miguilim tinha Dito como "a pessoa melhor", "levado de esperto" (ROSA, 
1996, p. 25), aquele que "era menor mas sabia o sério, pensava ligeiro as coisas" (Idem, p. 21); assim, após o acidente no dia da fuga do mico-estrela, a morte fatídica de Dito traz profundo sofrimento ao garoto, e o enunciatário-leitor é levado a compartilhar a sua dor.

Na narrativa de Monteiro Lobato, "Negrinha” (ver Anexos, p. 229), temos a história de "uma pobre órfã de sete anos. Preta? Não; fusca, mulatinha escura, de cabelos ruços e olhos assustados" (LOBAT0, 2009, p. 19). 0 conto relata a vida de maus-tratos, regada de extrema crueldade, levada por Negrinha na casa de D. Inácia - "Batiam-lhe sempre, por ação ou omissão. A mesma coisa, o mesmo ato, a mesma palavra provocava ora risadas, ora castigos.” (p. 20). Reduzida à condição de "coisa" por todos a sua volta, um dia, porém, a menina é levada a descobrir que o modo de viver com o qual a "mimoseavam" não era o normal - "Quê? Pois não era crime brincar? Estaria tudo mudado - e findo o seu inferno - e aberto o céu?" (p. 23). Uma vez consciente da condição de coisa a que tinha sido submetida, e sabendo agora que também era gente - "Negrinha, coisa humana, percebeu nesse dia da boneca que tinha uma alma." (p. 25) -, a pequena órfã cai numa profunda tristeza que a leva à morte. De carga emocional intensa, toda a estória, do dito ao modo de dizer, evoca o sentimento de piedade e compaixão.

Nessa mesma linha é retratada a situação narrada no conto "Baleia", de Graciliano Ramos (ver Anexos, p. 231), quando "a cachorra Baleia estava para morrer" (RAMOS, 2009, p. 95). Vendo-a, então, "sempre de mal a pior" (p. 95), Fabiano, no ímpeto de lhe abreviar o sofrimento, resolve matá-la, causando o desespero dos filhos e o pesar de Sinhá Vitória, afinal "ela era como uma pessoa da família: brincavam juntos os três, para bem dizer não se diferenciavam" (p. 95). Executada a ação, a estória volta-se a explorar o íntimo da cachorra nos momentos de agonia que lhe antecedem a morte. Oscilando entre a desgraça do momento presente e as lembranças de um tempo de outrora, a subjetividade da cachorra é trazida à tona, permitindo uma assimilação mais sensível do narrado, do acontecimento que lhe tira a vida levando-a de fato à morte.

As quatro histórias privilegiam, sobretudo, a produção de efeitos passionais próprios à manifestação da interação por compaixão e piedade, estabelecendo, ao 
que nos parece, modos de interação afetiva diversificados por parte do enunciatário-leitor; ora por uma simetria, ora por uma assimetria de lugares, para os quais prepondera, conforme o caso, ou a sensibilidade emocional, ou a inteligibilidade moralizante. Buscaremos, então, conforme assinalado anteriormente, depreender, a partir do exame dessas narrativas, as especificidades das condições de emergência do valor no campo perceptivo do enunciatário, por acreditarmos ser elas as responsáveis pela tensão que particulariza a interação afetiva suscitada no processo de leitura - mais da ordem do sensível, do "sentir com", ou mais da ordem do inteligível, como no caso do "sentir por".

Interessam, em primeiro lugar, as estratégias enunciativas adotadas, através das quais se instaura o campo de presença, o território tensivo no qual se concretiza a relação perceptiva entre o sujeito e o valor investido no objeto, ou, mais propriamente, entre o enunciatário e o valor investido nos atores do enunciado. Importa identificar e analisar quais valores estão em jogo, como o enunciador os "apresenta" ao enunciatário-leitor, e a partir de que circunstâncias tensivas se consolida a presença, a interação dele com as personagens, com os valores em jogo. Como explica Bertrand (2003, p. 112), "diretamente ligados à instância do discurso, esses meios controlam os modos de acesso à significação para o leitor. As seleções operadas orientam a apreensão do sentido e a dos valores".

\subsubsection{Sintaxe discursiva e textual: o gerenciamento da percepção e da interação patêmica pelos procedimentos de discursivização e textualização}

Todo enunciado, como se sabe, pressupõe uma enunciação responsável pelo "conjunto dos procedimentos capazes de instituir o discurso como um espaço e um tempo, povoado de sujeitos outros que não o enunciador" (Greimas; Courtés, 2008, p. 167). Nessa atividade produtiva estão contidos tanto o sujeito responsável pela atualização das virtualidades da língua, transformando-a em discurso, quanto o enunciatário, levado em conta neste momento por ser ele quem, de fato, torna realizada a significação. Enquanto o primeiro se coloca como destinador- 
manipulador dos valores e de seus modos de inserção no discurso, o segundo ocupa a posição de destinatário, apreendendo e interpretando a intencionalidade discursiva configurada. Conforme destaca Bertrand (2003, p. 24):

Nessa perspectiva, o leitor não é mais aquela instância abstrata e universal, simplesmente pressuposta pelo advento de uma significação textual já existente, que se costuma chamar "receptor" ou "destinatário" da comunicação: ele é também e sobretudo um "centro do discurso", que constrói, interpreta, avalia, aprecia, compartilha ou rejeita significações.

É por isso que, ao construir o seu enunciado, a instância enunciante busca gerenciar o contato do enunciatário com o texto e os efeitos de sentido (passionais) a partir daí (re)produzidos. A interação afetiva estabelecida com os atores do enunciado fica, pois, condicionada à maneira de dizer assumida pelo enunciador, às estratégias discursivas e textuais que ele adota para a transmissão e sensibilização do conteúdo de seu enunciado, definindo um modo próprio de apreender a significação do texto como um todo, de perceber, sensível e inteligivelmente, o que se passa. Mais do que o conteúdo em si, é a maneira escolhida pelo enunciador para o apresentar ao enunciatário a responsável pelos efeitos de sentido produzidos, pela reação afetiva que este último expressa.

Essa escolha de uma "maneira de dizer", de "disponibilizar" o conteúdo, e, em consequência, os valores que o sustentam, diz respeito aos procedimentos de discursivização e textualização adotados pelo enunciador no momento da construção do enunciado. Eles respondem pelo conjunto de seleções feitas nos diferentes níveis do percurso gerativo, responsáveis pelo gerenciamento da percepção do enunciatário-leitor, bem como do envolvimento afetivo desencadeado durante o processo de leitura, de realização da significação somente atualizada pela instância produtora do enunciado, conforme buscamos demonstrar no esquema abaixo (cf. Esquema 3.1): 

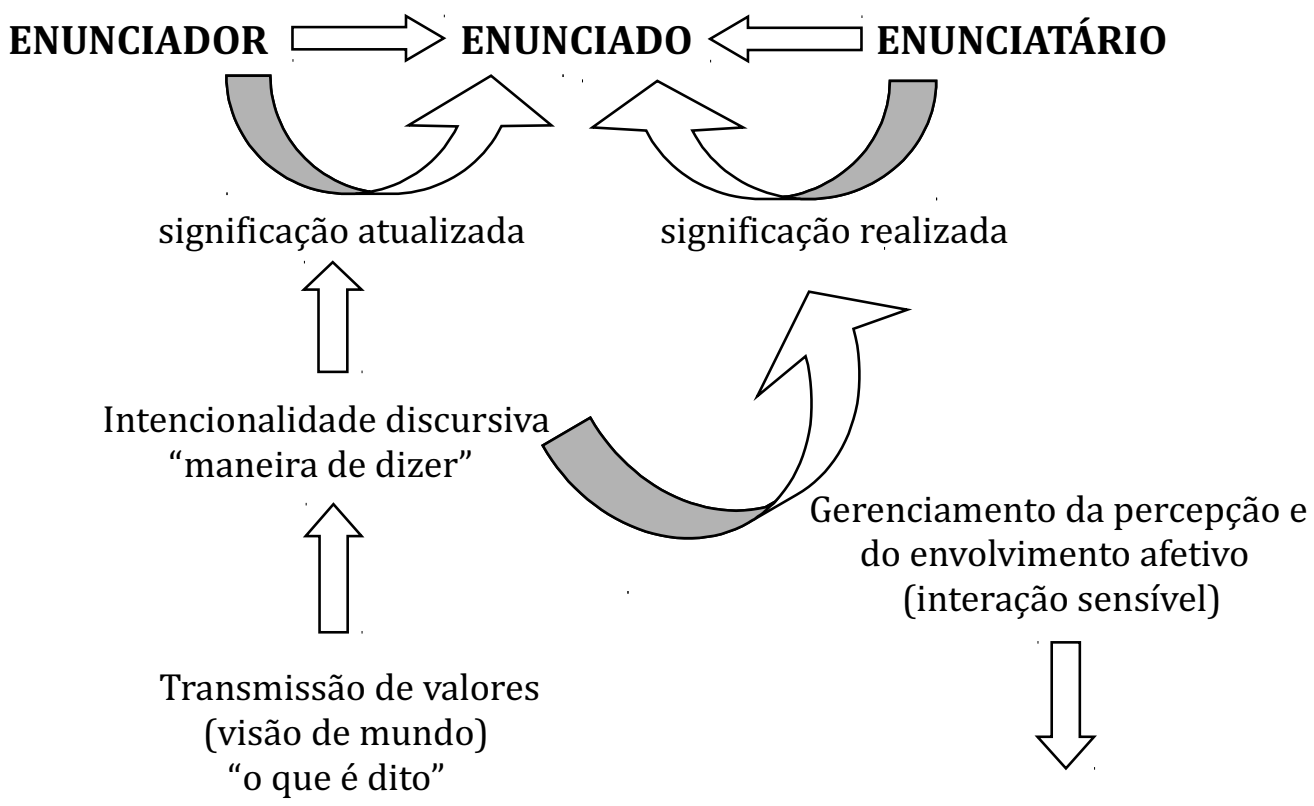

Transmissão de valores

(visão de mundo)

o que é dito"

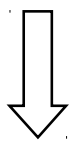

Configuração do "valor do valor" (interação inteligível)

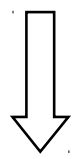

AFETIVIDADE / PAIXÃO

Esquema 3.1: 0 contato com o texto e a configuração da significação.

Os procedimentos de discursivização e textualização integram o domínio de atuação da intencionalidade discursiva, "que, mesmo não se identificando nem com o [conceito] de motivação nem com o de finalidade, os subsume" (GREIMAS; COURTÉS, 2008, p. 267); isso porque, conforme explica Eco (1987, p. 1273), “a dinâmica abstrata pela qual a linguagem se organiza em forma de texto possui leis próprias, produzindo um sentido que independe da vontade daquele que o enuncia". Ao responder pelo modo de apreensão do sentido e dos valores em jogo por parte do enunciatário, ambos os procedimentos estão intimamente relacionados à realização da predicação tensiva que faz do enunciado um campo de presença.

73 Trecho original: “[...] la dynamique abstraite à travers laquelle le langage s'ordonne em forme de textes possède ses lois propes et produit du sens indépendamment de la volonté de celui qui l'énnonce." 
Passíveis de gerenciar a percepção e o envolvimento afetivo, por determinarem a maneira específica pela qual o enunciatário toma conhecimento do que é dito, as estratégias discursivas e textuais respondem, nesse sentido, não só pela manifestação da estruturação semântico-sintáxica do texto a partir de determinada linguagem, mas também pela predicação tensiva que configura e sensibiliza o enunciado. Como assinala Fontanille (2007, p. 109):

[...] um esquema discursivo é uma forma inteligível, que mantém o elo com o universo do sensível: de fato, cada ato de enunciação reativa essas duas dimensões do sentido concomitantemente. Os esquemas discursivos exprimem, em suma, o elo entre o que nós compreendemos do discurso e nossa apreensão sensível de sua presença.

As modulações de intensidade e extensidade subjazem a dimensão figurativa do discurso e, ao atuar diretamente na articulação da "resposta" sensível e inteligível suscitada no contato do enunciatário com o texto, influem, por conseguinte, na configuração da interação afetiva com o conteúdo expresso, na produção do "valor do valor", ou seja, na sanção intersubjetiva que responde pela produção do valor tímico que o enunciatário atribui aos valores axiológicos apresentados no enunciado.

Dessa forma, enquanto a discursivização se encarrega dos componentes de projeção do enunciado (pessoa, tempo, espaço) e das configurações discursivas ${ }^{74}$ (figuras e temas) próprias ao plano de conteúdo, a textualização, por sua vez, “é o conjunto dos procedimentos - chamados a se organizarem numa sintaxe textual que visam à constituição de um contínuo discursivo, anteriormente à manifestação do discurso nesta ou naquela semiótica" (GREIMAS; COURTÈS, 2008, p. 504). Ou seja, ela representa a ancoragem do conteúdo articulado a um plano de expressão, aproveitando os recursos próprios à linguagem de manifestação escolhida, para, muitas vezes, não apenas propagar o conteúdo, mas também o intensificar, expressando um sentido implícito.

74 Aqui entendidas como "espécies de micronarrativas que têm uma organização sintáticosemântica autônoma e são suscetíveis de se integrarem em unidades discursivas mais amplas, adquirindo então significações funcionais correspondentes ao dispositivo de conjunto" (GREIMAS \& COURTÉS, 2008, p. 87). 
Para esclarecer o que até aqui foi apresentado, passaremos agora à análise dos textos selecionados, lembrando que o objetivo principal é o de poder verificar e cotejar as diferentes estratégias discursivo-textuais adotadas e, assim, os distintos modos de interação afetiva suscitados, confirmando (ou não) a coerência das proposições teórico-metodológicas levantadas nos capítulos anteriores.

\section{2 “Campo Geral” e “Conversa de bois”, de Guimarães Rosa: a configuração de diferentes modos de interação afetiva}

Cientes de que o estabelecimento da relação intersubjetiva do enunciatárioleitor com os atores do enunciado é o elemento-chave para a configuração do enternecimento de base do efeito passional próprio ao "sentir com" (mais sensível) ou ao "sentir por" (mais inteligível), interessa-nos agora compreender a forma pela qual é suscitada essa sensibilização; ou seja, depreender quais são as estratégias e os procedimentos discursivo-textuais mobilizados para este fim. Para isso, como salientamos anteriormente, iremos nos deter, durante a análise, nas cenas em que estão concentrados os núcleos patêmicos dos enunciados em questão.

Nas duas narrativas rosianas escolhidas, temos retratado o sofrimento de uma criança perante a morte de um ente querido. Em "Conversa de bois", essa temática perpassa todo o conto, e a tristeza de Tiãozinho pela morte do pai é uma das fontes da ligação afetiva que se institui entre ele e o enunciatário. No caso de "Campo Geral", o momento da morte de Dito, pico de intensidade máxima da história de Miguilim, figura dentre várias outras situações e aventuras vividas pelo garoto, a partir das quais a interação com o leitor já vai se instituindo e firmando um elo, uma identificação.

Em “Conversa de bois”, a projeção de pessoa, tempo e espaço funciona como alicerce do enunciado e constitui-se sobre uma complexa estrutura de encaixes, com, pelo menos, três histórias circunscritas: a inicial, na qual é retratado o diálogo entre Manuel Timborna e o narrador não nomeado, sobre a capacidade dos bois de conversarem entre si e com os homens; a principal, figurando como o causo contado por Timborna sobre a trajetória do carro de bois do carreiro Agenor 
Soronho, guiado por Tiãozinho até o cemitério do arraial; e a subordinada, passível de ser (re)constituída a partir dos pensamentos e lembranças do menino guia. A primeira emoldura a segunda, que, por sua vez, engloba a terceira.

Essa variação na organização e disposição do espaço enunciativo, ao condicionar a oscilação da posição do centro perceptivo e, da mesma forma, da assunção do discurso, faz do campo de presença criado entre o enunciatário-leitor e os atores do enunciado um espaço de profundidade fluida. 0 início do conto instaura o eu-aqui-agora da enunciação enunciada e presentifica, assim, o diálogo entre o narrador e Timborna, projetando o causo narrado, no qual se inclui o sofrimento vivido por Tiãozinho, em um ele-lá-então, que toma forma aos olhos do enunciatário, mantido no espaço da enunciação pressuposta, isto é, "do lado de fora" do enunciado, como espectador:

Que já houve um tempo em que eles conversavam, entre si e com os homens, é certo e indiscutível, pois que bem comprovado nos livros das fadas carochas. Mas, hoje-em-dia, agora, agorinha mesmo, aqui, aí, ali, e em toda parte, poderão os bichos falar e serem entendidos, por você, por mim, por todo o mundo, por qualquer um filho de Deus?!

- Falam, sim senhor, falam!... - afirma o Manuel Timborna, das Porteirinhas, [...]

- Pode que seja, Timborna. Isso não é de hoje: ... "Visa sub obscurum noctis pecudesque locutae. Infandum!..." Mas, e os bois? Os bois também?...

- Ora, ora!... Esses é que são mais!... Boi fala o tempo todo. Eu até posso contar um caso acontecido que se deu. [...]

E começou o caso, na encruzilhada da Ibiúva, logo após a cava do Mata-Quatro, onde, com a palhada de milho e o algodoal de pompons frouxos, se trucam as derradeiras roças da Fazenda dos Caetanos e o mato de terra ruim começa dos dois lados; [...]

Seriam bem dez horas, e, de repente, começou a chegar - nhein... nheinhein... renheinhein... - do caminho da esquerda, a cantiga de um carro-de-bois. [...]

Mal se amoitara, porém, e via surgir, na curva de trás da restinga, o menino guia, o Tiãzinho - um pedaço de gente, com a comprida vara no ombro, com o chapéu de palha furado, as calças arregaçadas, e a camisa grossa de riscado, aberta no peito e excedendo atrás em fraldas esvoaçantes.

Vinha triste, mas batia ligeiro as alpercatinhas, porque, a dois palmos da sua cabeça, avançavam os belfos babosos dos bois da guia [...] (ROSA, 2001, p. 325-327, grifo nosso) 
Cria-se, pois, uma maior profundidade entre os interactantes dentro do campo de presença, de maneira que a atividade perceptiva do enunciatário se faz de modo mais objetivo, mais distanciado. Mas, uma vez iniciada a história contada por Manuel Timborna, dilui-se a conversa dele com o narrador, e a narrativa, conduzida por uma instância enunciante onisciente, privilegiando, todavia, ainda um ponto de vista externo, passa agora a ocupar o centro da atenção do enunciatário, que, como observador também exterior, passa a (re)compor o enunciado na medida em que este vai debreando-se e dando a ver o seu cenário e seus atores.

Na extensa descrição inicial, a aparição de Tiãozinho, designado "triste", sem maiores detalhes e explicações, antes mesmo de o enredo se delinear claramente, provoca uma tensão entre o saber absoluto do narrador e aquele oferecido ao leitor - por que triste? 0 que teria acontecido? - instaurando, então, um primeiro vínculo entre a personagem e o enunciatário-leitor, agora ansioso por mais informações enquanto os outros atores do enunciado continuam a ser detalhadamente apresentados. De qualquer forma, esse "movimento" em direção à personagem, ao fundamentar um não-saber o porquê da tristeza - que funciona como uma primeira estratégia de sensibilização -, é ainda predominantemente de ordem cognitiva. E o narrador insiste:

\footnotetext{
Como aquele trecho da estrada fosse largo e nivelado, todos iam descuidosos, em sóbria satisfação: Agenor Soronho chupando o cigarro de palha; o carro com petulância, arengando; a poeira dançando no ar, entre as patas dos bois, entre as rochas do carro e em volta da altura e da feiúra do Soronho; e os oitos bovinos, sempre abanando as caudas para a mosquitada, cabeceantes, remoendo e tresmoendo o capim comido de-manhã.

Só Tiãozinho era quem ia triste. Puxando a vanguarda, fungando o fio duplo que lhe escorria das narinas, e dando a direção e tenteando os bois. (ROSA, 2001, p. 329, grifo nosso)
}

Mais uma vez é anunciada a tristeza do menino guia sem qualquer elucidação. 0 enunciatário-leitor, já ligado a ele, e a partir daí à própria história, segue em busca de um esclarecimento, que só virá após algumas cenas (p. 332), quando a viagem tem a sua primeira interrupção: 
Acolá, longe adiante, onde as árvores dos dois lados se encontram e o caminho se fecha aos olhos da gente, apontaram de repente uns cavaleiros. Vêm chegando. Para que eles possam passar, mesmo tendo de contornar o barranco, Tiãozinho detém os bois.

- Boas tardes, seu Agenor! Que é que vão carreando?

- Umas rapadurinhas pretas, mais um defunto... É o pai do meu guia, que morreu p'r'amanhecer hoje...

- Virgem Santa, seu Agenor! Imagina, só, que coisa triste... - Os homens se descobrem. - E de que foi mesmo que o pobre morreu, seu Agenor, ele que era tão amigo do senhor...?

- A gente não sabe... Da doença antiga lá dele... 0 coitado andava penando.

- Pobrezinho do menino!... - exclama a moça do silhão. E, a tais palavras, Tiãozinho, que já estava meio quase consolado, recebe inteira, de volta, sua grande tristeza outra vez. (ROSA, 2001, p. 332 , grifo nosso)

Nesse trecho, quando o leitor, enfim, vai poder compreender o motivo da tristeza do garoto, a história se presentifica - como demonstram os verbos indicadores das ações ocorridas no presente do indicativo e o discurso direto subsequente -, substituindo o lá-então pelo aqui-agora, que diminui a distância estabelecida no campo de presença e coloca o enunciatário, de certa forma, "dentro" do enunciado, como testemunha ocular do narrado, como se figurasse entre os cavaleiros que também acabam de saber do acontecido. No entanto, tendo sido instigado anteriormente por um não-saber o porquê da tristeza de Tiãozinho, a notícia da morte do pai do menino perde sua força de impacto sensibilizador porque aparece como resposta, como elucidação da tristeza de Tiãozinho. Ademais, o seu compadecimento pelo sofrimento do pequeno guia, tal como o daqueles homens, advém de uma inferência, um "imaginar a dor" do pobre menino a partir do sucedido e não de um comportamento manifestado e observável, como confirma a ressalva do narrador: “(...) Tiãozinho, que já estava meio quase consolado (...)" (p. 332).

Os valores colocados em cena, e com eles o acento de sentido passional, provêm, então, do entorno, da notícia do falecimento do pai, a partir da qual o sofrimento do garoto vem para o enunciatário-leitor, como dissemos, como fato, como implicação. Embora a profundidade do campo de presença diminua, aproximando enunciatário-leitor e personagem, o modo de gerenciamento da atenção utilizada pelo enunciador, fundada na incitação dominantemente cognitiva, 
diminui a força tímica das figuras, para as quais prevalece o valor de informação semântica. Trata-se do que Fontanille (1999) chama de estratégia cumulativa, na qual conjugam-se uma intensidade de menor impacto, própria a um saber mais difuso e instável, e uma extensidade importante, na qual é privilegiada a quantidade, a apreensão do entorno. A sensibilização que leva o enunciatário a lamentar o ocorrido configura-se, pois, como um pesar de origem mais inteligível do que sensível, resultando na produção de um "sentir por".

A história continua e uma nova tensão entre os saberes do narrador e do enunciatário-leitor é instaurada:

\begin{abstract}
Agora, o carreiro, sim, que é homem maligno. 0 dia, para ele, amanheceu feliz. Mas, mesmo assim por assim, só porque está suando, não deixa de implicar:

- Tu Tião, diabo! Tu apertou demais o cocão!... Não vê que a gente carreando defunto-morto, com essa cantoria, até Deus castiga, siô?!... Não vê que é teu pai, demoninho?!... Fasta! Fasta, Canindé!... Ôa!... Ô-ôa!... Anda, fica novo, bocó-sem-sorte, cara de pari sem peixe! Vai botar azeite no chumaço, que senão agorinha mesmo pega fogo no eixo, pega fogo em tudo, com o diabo p'r'ajudar!...

Tiãozinho veio no grito, mas se mexendo encolhido, com medo de que o homem desse nele com a vara-de-ferrão. (ROSA, 2001, p. $336,337)$
\end{abstract}

Uma série de contrastes é colocada e, mais uma vez, sem explicações: por que, apesar da morte do "amigo" naquela manhã, o dia teria amanhecido feliz para o carreiro? Por que, mesmo ciente do sofrimento de Tiãozinho, Agenor Soronho age de forma tão rude e cruel? Mesmo que a tensão criada suscite o sentimento de indignação, essa recorrência da instigação cognitiva do enunciatário afeta a configuração da sua interação sensível com a personagem e o leva a continuar dando mais atenção aos fatos apresentados na extensão do relato, sempre em busca de maiores informações e esclarecimentos, do que à força deles sobre a timia do menino. Há, sem dúvida, uma intersubjetividade que fundamenta o pesar provocado, mas ela se mantém como uma postura sobretudo moralizante por parte do enunciatário-leitor, mais do que emocional.

Mesmo que a continuação do tempo presente na narração da história conserve o efeito de simetria entre o tempo-espaço do enunciado e o da 
enunciação pressuposta e garanta, assim, a convocação do enunciatário-leitor como testemunha ocular do narrado, o desequilíbrio entre os saberes dele e do enunciador - sustentado pelo ponto de vista externo de pendor acentuadamente descritivo e limitado à representação das características superficiais e materialmente observáveis (REIS \& LOPES, 2007) - enfraquece a sua participação direta, a sua interação sensível, mantendo-o como observador exterior, distanciado.

Quando a subjetividade de Tiãozinho emerge, por meio de seus pensamentos e lembranças, no discurso e ocupa o primeiro plano na narrativa, expondo os conflitos que representam o seu sofrimento a partir de um discurso indireto livre fundado em um ponto de vista interno, próximo ao monólogo interior, ainda assim o envolvimento afetivo do leitor parece permanecer sob o domínio do inteligível. Principalmente porque essas reflexões, ao recompor a situação vivida pelo garoto, permitem ao enunciatário-leitor (re)construir os acontecimentos anteriores, esclarecendo as coisas:

Chora-não-chora, Tiãozinho retoma o seu posto. "O pai não é meu, não... 0 pai é seu mesmo..." Decerto. Ele bem que sabe, não precisa de dizer. É seu pai quem está ali, morto, jogado para cima das rapaduras... Deixou de sofrer... Cego e entrevado, já de anos, no jirau... Tiãozinho nem se lembrava dele de outro jeito, nem enxergando nem andando... Às vezes ele chorava, de-noite, quando pensava que ninguém não estava escutando. Mas Tiãozinho, que dormia ali no chão, no mesmo cômodo da cafua, ouvia, e ficava querendo pegar no sono, depressa, para não escutar mais... Muitas vezes chegava a tapar os ouvidos, com as mãos. Malfeito! Devia de ter, nessas horas, puxado conversa com o pai, para consolar... Mas aquilo era penoso... Fazia medo, tristeza e vergonha, uma vergonha que ele não sabia bem por quê, mas que dava vontade na gente de querer pensar em outras coisas... E que impunha, até, ter raiva da mãe...

- Ôa!... Ôa, boi teimoso... Buscapé, demônio!

Ah, da mãe não gostava!... Era nova e bonita, mas antes não fosse... Mãe da gente devia de ser velha, rezando e sendo séria, de outro jeito... Que não tivesse mexida com outro homem nenhum... Como é que ele ia poder gostar direito da mãe?... Ela deixava até que o Agenor carreiro mandasse nele, xingasse, tomasse conta, batesse... Mandava que ele obedecesse ao Soronho, porque o homem era quem estava sustentando a família toda. Mas o carreiro não gostava de Tiãozinho... E era melhor, mesmo, porque ele também tinha ojeriza daquele capeta!... Ruço!... Entrão!... Malvado!... O demônio devia de ser assim, sem tirar e nem pôr... Vivia dentro da 
cafua... Só não embocava era no quartinho escuro, onde o pai ficava gemendo; mas não gemia enquanto o Soronho estava lá, sempre perto da mãe, cochichando os dois, fazendo dengos... Que ódio!...

0 caminho, descurvo, vai liso para a frente. E, lá léguas, meão roxo, é o Morro Selado, onde mora um sujeito maluco, que tem ouro enterrado no chão.

Pobre do pai!... [...] (ROSA, 2001, p. 338, 339, grifo nosso)

Nessa passagem, o posicionamento externo do narrador dá lugar a um ponto de vista interno que põe em cena a perspectiva de Tiãozinho, com a apresentação do sucedido submetida a sua reflexão interiorizada. A subjetividade emergente - e com ela os esclarecimentos pelos quais procurava o enunciatário provém, dessa forma, do presente da enunciação enunciada, manifestada na embreagem enunciva de segundo grau (enuncia-se um ele no qual está contido um $e u$ ), e não do momento do acontecido, de maneira que esse rememorar distribui a intensidade ao longo da exposição das situações recordadas, revividas.

Essa distinção entre o "aqui-agora da lembrança" e o "lá-então do lembrado" é enfatizada no texto pela interposição dos pensamentos do pequeno guia às breves retomadas do momento da trajetória até o arraial. Discretizam-se o eu do acontecido rememorado e o eu enunciante da lembrança. As paixões daí procedentes - o rancor, o ressentimento, o desgosto, a tristeza - são resultado, portanto, de uma postura moralizante do próprio garoto diante do decorrido.

Dessa "terceira narrativa", a subordinada, o enunciatário toma conhecimento apenas por intermédio das ruminações de Tiãozinho, não a presenciando de fato. Ele precisa, então, entender o que e como as coisas ocorreram, reconstituindo o entorno, para somente depois melhor apreender o estado de alma do pequeno guia. 0 entendimento do enunciatário em relação à história trazida à tona pelas lembranças do menino é, nesse sentido, mediado e solicita abstração, na qual mais uma vez prevalecerá a (re)constituição e compreensão dos fatos anteriores ao momento da viagem.

Mesmo a relação da personagem com as suas recordações é sancionadora; Tiãozinho não revive os fatos através de sua sensibilidade estésica, mas os interpreta e os julga. É por isso que a assimilação inteligível do enunciatário-leitor, 
ligada à quantidade de informações (eixo da extensidade), prepondera sobre a experiência sensível dessa apreensão (eixo da intensidade); e o compadecimento configura-se como um "sentir por", originário de um crer-saber-aderido.

A história de "Campo Geral", por sua vez, tem uma estruturação de pessoa, tempo e espaço parecida, mas menos complexa. Ao iniciar a estória também com uma narração em terceira pessoa que instaura um ele-lá-então para o discurso enunciado, preponderante em relação ao eu-aqui-agora da enunciação enunciada, a narrativa coloca em cena, da mesma forma como se verifica no início de "Conversa de bois", certo efeito de sentido de distanciamento - entre a enunciação e o enunciado - e, da mesma maneira, também de objetividade, do eu em relação ao ele, do presente perante o passado, do aqui diante o lá, tal como mostra o trecho abaixo:

UM CERTO MIGUILIM morava com sua mãe, seu pai e seus irmãos, longe daqui, muito depois da Vereda-do-Frango d'Água e de outras veredas sem nome ou pouco conhecidas, em ponto remoto, no Mutum. No meio dos Campos Gerais, mas no covão em trecho de matas, terra preta, pé de serra. Miguilim tinha oito anos. Quando completara sete, havia saído dali, pela primeira vez [...] (ROSA, 1996, p. 13, grifo nosso)

Não demora muito, todavia, para que esse efeito de distanciamento e objetividade, de maior profundidade do campo de presença, confunda-se com uma proximidade e subjetividade advindas do próprio conteúdo discursivo. Nele passa a prevalecer a interioridade da personagem central, com sua reflexão infantil, seu posicionamento e percepção sensível em relação aos outros atores do enunciado, aos acontecimentos, à realidade circundante, como podemos verificar nesta passagem:

Os irmãos já estavam acostumados com aquilo, nem esbarravam mais dos brinquedos para vir ver Miguilim sentado alto no tamborete, à paz. Só o Dito, de longe distante, pela porta, espiava leal. Mas o Dito não vinha, não queria que Miguilim penasse vergonha.

Aonde o pai teria ido? De ficar botado de castigo, Miguilim não se queixava. Deixavam-no, o ruim se acabara, as pernas iam terminando de doer, podia brincar de pensar, ali, no quieto, pegando nas verônicas que tinha passadas por um fio, no pescoço, 
e que de vez em quando devia de beijar, salgando a boca com o fim de suas lágrimas. (ROSA, 1996, p. 23)

Através de um ponto de vista interior, a "voz" do narrador parece apagar-se, perdendo densidade de presença e dando lugar à de Miguilim, a qual, mesmo não projetada em primeira pessoa, ressoa no enunciado debreado pelo narrador e passa a ocupar o primeiro plano. Enuncia-se um ele sobre a perspectiva de um $e u$, e o lá-então do enunciado, ao trazer à superfície do discurso, com maior densidade de presença, a subjetividade da experiência do acontecido, transforma-se no aquiagora da enunciação.

Como esclarece Fiorin (2008, p. 82), “o que há é, como mostra Bakhtin, uma discordância enunciativa entre as duas vozes. Essa discordância não é tanto de sentido, é de tom". Confundem-se as barreiras entre o que é da ordem da narração e o que é da ordem do narrado, carregando o discurso de uma passionalidade que convoca a sensibilidade do enunciatário-leitor e, pelo compartilhamento das percepções e sensações do menino, torna-o parte do enunciado. Vejamos o trecho:

\begin{abstract}
Os enxadeiros tinham ido cortar varas do mato, uma vara grande de pindaíba, e Pai desenrolou a redezinha de buriti. Mas aí Mãe exclamou que não, que queria o filhinho dela no lençol de alvura. Então embrulharam o Dito na colcha de chita, enfeitaram com alecrins, e amarraram dependurado na vara comprida. Pai pegou numa ponta da vara, seo Braz do Bião segurou na outra, todos os homens foram saindo. Miguilim deu um grito, acordado demais. Vovó Izidra rezava alto, foi o derradeiro homem sair e ela fechou a porta. E sojigou Miguilim debaixo de sua tristeza. (ROSA, 1996, p.111)
\end{abstract}

Ao operar sobre o modo do discurso indireto livre, o narrador de "Campo Geral", instância responsável pela transmissão do conteúdo (aquele que narra), adentra a interioridade do menino e traz à cena a figura do observador (aquele que vê). Os fatos passam a ser apresentados a partir do íntimo de Miguilim, que não apenas assiste aos acontecimentos e os dá a conhecer, mas os percebe, vive e perscruta. Diferente do posicionamento crítico de Tiãozinho em "Conversa de bois", sua percepção é da ordem do sensível e faz prevalecer a experiência estésica, que patemiza o acesso à significação, aos valores. Institui-se, assim, uma embreagem 
completa: actancial, porque estabelece um sujeito da ação que age, manipula, sanciona; espaço-temporal, com a observação feita no lugar e no tempo da narrativa; actorial, por estar subjugada a um ator participante da narrativa; e temática, pois a percepção colocada em cena tem um sentido e um valor em relação ao contexto da história (FONTANILLE, 1989).

A principal diferença em relação ao que acontece na narrativa de Tiãozinho parece estar na estratégia de orientação discursiva que, fundada não em uma incitação cognitiva, mas dominantemente sensível, de partilha dos pensamentos e das emoções da personagem, incita a cumplicidade do enunciatário-leitor, a sua simpatia por Miguilim. Ademais, conta também o fato de essa subjetividade não provir do já sucedido, do rememorar, mas de uma experiência "presentificada" pela embreagem enunciva, responsável pela ênfase dada não somente àquilo que se conta, mas, sobretudo, à "experimentação" dos fatos, do espaço e do tempo em si.

A neutralização operada pela embreagem resgata a pessoa, o tempo e o espaço do ocorrido, e, dessa forma, presentifica o já acontecido, fazendo com que o enunciatário-leitor, no processo de leitura, sinta como se não apenas tomassemos conhecimento da história, mas a "presenciasse". Ao contrário do que se passa em "Conversa de bois", as qualidades sensíveis que emergem do enunciado de "Campo geral" - a partir da perspectiva operante de Miguilim - predominam sobre a quantidade de informações. 0 uso do discurso indireto livre, ao instaurar no enunciado, além da debreagem enunciativa (narrador), uma embreagem actancial enunciva de segundo grau (ator do enunciado), determina a posição e o modo de presença do enunciatário-leitor em relação à narrativa e, a partir dela, à própria personagem.

Ao iniciar a história com uma narração em terceira pessoa, o enunciador põe o enunciatário a seu lado, ou seja, "do lado de fora" do enunciado construído, como espectador, oferecendo-lhe uma visão externa, mais distanciada e objetiva dos fatos e dos valores que a ele subjazem. Por outro lado, ao dar voz, pelo uso do discurso indireto livre, e maior densidade de presença a Miguilim, ele convoca e coloca o enunciatário-leitor "dentro" do narrado, em uma ligação mais direta com a personagem, permitindo-lhe conhecer o mundo e os acontecimentos que cercam o 
menino a partir de sua visão pueril, de sua subjetividade, como participante da história.

Como coloca Oliveira (1995, p. 234), “o enunciatário, desse modo, participa do desenrolar das ações, reage às tensões, julga-as e, apaixonadamente, responde aos efeitos discursivos mesmo que seu fazer nada possa transformar". Cria-se uma identificação, uma ligação entre ele e a personagem, e, como acrescenta a autora, "a aliança mesmo dos dois actantes, um no texto e o outro fora ou, ao menos, à margem, é que proporciona ao segundo ser levado pelo primeiro à significação e nessa embrear-se a tal ponto na rede de transformações que, como seu participante, sente-a inteiramente" (Idem, p. 235). A apreensão do conteúdo e dos valores através dele transmitidos é, pois, sensibilizada e, por isso mesmo, impacta afetivamente a sua interpretação. 0 valor que o enunciatário-leitor atribui aos valores apresentados no texto fica subjugado ao modo de ver e de sentir de Miguilim, e a assimilação passa a ser mais da ordem do sensível do que do inteligível, configurando um crer-saber-assumido, um "sentir com".

Ao contrário do que se tem em "Conversa de bois", o modo de mobilização dos componentes da sintaxe discursiva (pessoa, tempo, espaço) na estruturação narrativa de "Campo Geral" aponta para uma estratégia eletiva que concentra a intensidade na figura do menino, da qual emanam os valores, com o acento de sentido colocado no impacto dos acontecimentos narrados sobre ele, em seus estados de alma, condizentes ao eixo da intensidade, e não sobre os estados de coisas próprios ao eixo da extensidade, aos entornos, como ocorre na estória de Tiãozinho. Os procedimentos de discursivização, de organização e disposição do espaço enunciativo construído, regem, como se pode ver, a percepção do enunciatário-leitor e, a partir dela, a especificidade qualitativa da sua interpretação, da configuração do "valor do valor".

Ao fundamentar a estratégia de gerenciamento da afetividade em uma perspectiva predominantemente sensível, o enuniador provoca uma forte identificação entre o enunciatário-leitor e Miguilim, uma interação afetiva tônica, própria ao estabelecimento do crer-saber-assumido, do "sentir com".

Um segundo ponto a ser examinado em relação à depreensão das condições 
de emergência, no processo de leitura, do modo de interação afetiva entre o enunciatário-leitor e os atores do enunciado, firmados seja pelo sentimento de compaixão seja pelo de piedade, diz respeito à semântica discursiva (temas e figuras) dos textos, porque é a partir dela que os valores veiculados são apresentados à sensibilidade do sujeito da percepção. Esse é o momento, portanto, de identificar as circunstâncias desse acesso, da configuração da densidade de presença dos interactantes, logo, da força de impacto do objeto percebido, dos efeitos passionais suscitados sobre o sujeito da percepção, o enunciatário-leitor.

Os temas e as figuras são, por excelência, o lugar do ideológico no discurso. A escolha deles não é ingênua e o sentido veiculado carrega em si uma carga semântica e ideológica muito maior, que se potencializa não exatamente no que é contado, mas na forma de contar, de representar, figurativa e tematicamente, o conteúdo narrado. Interessa, nesse sentido, analisar, mais do que as figuras e os temas em si, a organização e a disposição figural desses elementos no texto, a maneira como eles manifestam os valores e mobilizam a percepção do enunciatário. Comparemos as passagens a seguir:

Arre! Que nunca foi tão penosa uma ida ao arraial. Também, com tudo tão triste, carreando o pai para a cova, coitado do pai... Mas, deve de ter subido para o Céu, direito, na mesma da hora... Na véspera de morrer, de-noite, ele ainda pedira para Tiãozinho tirar reza junto... E Tiãozinho puxara o terço, cochilando... Estava com muito sono, porque tinha ido, a pé, ao Marçal Velho, levar um recado... Depois da salve-rainha, o pai pôs nele a benção, e ele deitou no enxergão, para dormir logo, esquentando os molambos... Também não adiantou nada estar dormindo no mesmo canto; só deu fé daquela tristeza toda foi quando viu a mãe, chorando, sacudindo-o para levantar. Aí, Tiãozinho tinha chorado também... Mas a mãe, por que é que ela havia de chorar?! por quê? Ela não gostava do pai... Tiãozinho pouco pudera ver, pelos buracos da parede de pau-a-pique, quando eles estavam lavando o corpo... A cafua se enchera, não cabendo, de gente... E seu Agenor Soronho estava muito galante com todos. Estava mesmo alegre, torcendo as pontas do bigode vermelho, mas fazendo de estar triste, às vezes, de repente... E até, quando Tiãozinho, zonzo de tanta confusão, se sentara na pedra que faz degrau na porta da cozinha, o carreiro tinha vindo consolar sua tristeza, dizendo que daí em diante ia tomar conta dele de verdade, ia ser que nem seu pai...

Os vizinhos bem que estavam às ordens, para carregar cristão defunto. Mas eram seis léguas apuradas, e, como seu Agenor 
estava mesmo para levar uma carga de rapadura do Major Fréxes, dispensou os préstimos para o cortejo, e atrelou quatro juntas, porque na volta ia trazer o carro cheio, com os rolos de arame farpado que estavam esperando por ele, na estação do arraial... Não havia caixão: só o esquife tosco, entre padiola e escada, com as barras atadas com embira e cipó. Ajeitaram o morto em cima do ladrilhado das rapaduras. Tiãozinho, já pronto, esperava no seu lugar com muita pressa de sair porque aquilo tudo estava sendo ruim demais... (ROSA, 2001, p. 344, 345)

A reza não esbarrava. Uma hora o Dito chamou Miguilim, queria ficar com Miguilim sozinho. Quase que ele não podia mais falar. "Miguilim, e você não contou a estória da Cuca Pingo-de-Ouro..." “Mas eu não posso, Dito, mesmo não posso! Eu gosto demais dela, estes dias todos..." Como é que podia inventar a estória? Miguilim soluçava. - "Faz mal não, Miguilim, mesmo ceguinha mesmo, ela há de me reconhecer..." “- No Céu, Dito? No Céu?!" - e Miguilim desengolia da garganta um desespero. - "Chora não, Miguilim, de quem eu gosto mais, junto com a Mãe, é de você...” E o Dito também não conseguia mais falar direito, os dentes dele teimavam em ficar encostados, a boca mal abria, mas mesmo assim ele forcejou e disse tudo: - "Miguilim, Miguilim, vou ensinar o que agorinha eu sei, demais: é que a gente pode ficar sempre alegre, alegre, mesmo com toda coisa ruim que acontece acontecendo. A gente deve de poder ficar então mais alegre, mais alegre por dentro!..." E o Dito quis rir para Miguilim. Mas Miguilim chorava aos gritos, sufocava, os outros vieram, puxaram Miguilim de lá.

Miguilim doidava de não chorar mais e de correr por um socorro. Correu para o oratório e teve medo dos que ainda estavam rezando. Correu para o pátio, chorando no meio dos cachorros. Mãitina caminhava ao redor da casa, resmungando coisas na linguagem, ela também sentia pelo estado do Dito. - "Ele vai morrer, Mãitina?!" Ela pegou na mão dele, levou Miguilim, ele mesmo queria andar mais depressa, entraram no acrescente, lá onde ela dormia estava escuro, mas nunca deixava de ter aquele foguinho de cinzas que ela assoprava. - "Faz um feitiço para ele não morrer, Mãitina! Faz todos os feitiços, depressa, que você sabe..." Mas aí, no vôo do instante, ele sentiu uma coisinha caindo em seu coração, e adivinhou que era tarde, que nada mais adiantava. Escutou os que choravam e exclamavam, lá dentro de casa. Correu outra vez, nem soluçava mais, só sem querer dava aqueles suspiros fundos. Drelina, branca como pedra de sal, vinha saindo: -- "Miguilim, o Ditinho morreu..."

Miguilim entrou, empurrando os outros: o que feito uma loucura ele naquele momento sentiu, parecia mais uma repentina esperança. O Dito, morto, era a mesma coisa que quando vivo, Miguilim pegou na mãozinha morta dele. Soluçava de engasgar, sentia as lágrimas quentes, maiores do que os olhos. Vovó Izidra o puxou, trouxe para o quarto. Miguilim sentou no chão, num canto, chorava, não queria esbarrar de chorar, nem podia. - "Dito! Dito!..." Então se levantou, veio de lá, mordia a boca de não chorar, para os 
outros o deixarem ficar no quarto. Estavam lavando o corpo do Dito, na bacia grande. Mãe segurava com jeito o pezinho machucado doente, como caso pudesse doer ainda no Dito, se o pé batesse na beira da bacia. 0 carinho da mão de Mãe segurando aquele pezinho do Dito era a coisa mais forte neste mundo. [...] Os enxadeiros tinham ido cortar varas do mato, uma vara grande de pindaíba, e Pai desenrolou redezinha de buriti. Mas aí Mãe exclamou que não, que queria o filhinho dela no lençol de alvura. Então embrulharam o Dito na colcha de chita, enfeitaram com alecrins, e amarraram dependurado na vara comprida. Pai pegou numa ponta da vara, Seo Braz do Bião segurou na outra, todos os homens foram saindo. Miguilim deu um grito, acordado demais. Vovó Izidra rezava alto, foi o derradeiro homem sair e ela fechou a porta. E sojigou Miguilim debaixo de sua tristeza. (Rosa, 1996, p. 107-111)

As duas cenas retratam o momento de maior sofrimento para Tiãozinho e Miguilim: a morte do ente querido, único e verdadeiro companheiro; e, de maneira geral, as figuras e os temas mobilizados são muito próximos e parecidos. A influência deles na configuração do pesar que sentirá o enunciatário-leitor é, no entanto, diferente e pode ser explicada através da articulação das modulações tensivas regidas pela perspectiva escolhida, subjugando o figurativo ao figural. Segundo Fontanille e Zilberberg (Idem, p. 313):

Para tal questão, duas vias são propostas: ou os valores são dados a serem conhecidos pelo sujeito semiótico, por exemplo na forma de um mandamento, sob a responsabilidade de um Destinador cognitivo; ou então são apresentados à sua sensibilidade, são dados a serem sentidos, sob modos figurativos. De um lado, o encontro com o valor é mediatizado por um papel actancial específico; do outro, o timismo difuso investido na figuratividade, e notadamente nas suas qualidades sensíveis, faz seu trabalho.

A figuratividade apresentada e dirigida por um dispositivo figural profundo concretiza, no primeiro enunciado, a perspectiva de Tiãozinho sobre o sucedido, trazendo à tona o que a sua lembrança privilegiou daquele momento $\mathrm{e}$ (re)construindo a cena para o enunciatário. 0 sofrimento do garoto é depreensível, ou melhor, é inferido, da totalidade manifestante, a partir dos entornos, com a intensidade distribuída a cada observação rememorada, a cada figura apresentada. O enunciatário-leitor, através delas, vai unindo os fatos, recompondo o ocorrido e 
concluindo, imaginando o penar do pequeno guia. A perspectiva em "Conversa de bois" é, então, mais ampla, aberta, e disponibiliza uma apreensão mais global do evento narrado, uma significação em devir na profundidade progressiva, orientada sobretudo pelas valências da extensidade: espacialidade e temporalidade. A tensão entre os valores que a figuratividade põe em jogo se distribui na extensão do campo de presença configurado no momento da leitura, diminuindo a sua força de impacto e possibilitando um processamento mais inteligível da presença, do objeto-valor da afetividade suscitada.

$\mathrm{Na}$ segunda narrativa, ao contrário, as figuras, principalmente aquelas inseridas e enfatizadas pelo narrador, manifestam mesmo o sofrimento vivido por Miguilim, tornando-o tônico e observável aos olhos do enunciatário-leitor e aumentando, por isso, a sua densidade de presença, o seu poder de influência sobre ele. A assimilação do conteúdo e dos valores que o sustentam torna-se, assim, mais sensível e impactante justamente porque o enunciatário-leitor pode "ver" a angústia e o desespero do menino, "vivenciando" a cena retratada e, por consequência, a sua dor. A perspectiva é fechada, local, totalmente concentrada na figura de Miguilim, em seu estado de alma, seu sofrimento, com a percepção do enunciatário-leitor atuando em foco, dirigida por uma profundidade regressiva na qual dominam as valências da intensidade: tonicidade e andamento. As figuras que concretizam a cena narrada não equivalem a um desdobramento da extensidade do campo de presença, mas concentram a tensão, a intensidade patêmica. Elas reiteram e, da mesma forma, tonificam o padecimento de Miguilim diante a morte do irmão.

A figurativização na passagem de "Conversa de bois", ao (re)constituir o "já decorrido", aparece, nesse sentido, em um contexto emocional moralizante - em um discurso do exercício, diria Zilberberg (2007) -, no qual o desenvolvimento figurativo permite a compreensão da situação e, a partir de então, a inferência do sofrimento de Tiãozinho, que, dada a divisão da carga tímica na extensão da apreensão, adquire valor de fato, de $e s t a d o^{75}$, de exercício. Já a dimensão figurativa de “Campo Geral" concretiza, diferentemente, o "não ainda", o "se fazendo", com as

75 Em obras posteriores, Zilberberg (2011) tem usado o termo estado como contraponto ao de acontecimento. 
figuras manifestando não apenas a situação, mas sobretudo a dor de Miguilim, o que caracteriza um ambiente patêmico fortemente sensível, definido pela concentração da intensidade, pelo valor de acontecimento, próprio aos enunciados de maior impacto.

Conforme coloca Fontanille (2007, p. 174), "no campo posicional, quanto mais se se distancia do centro, mais a presença enfraquece-se em relação ao centro; e quanto mais se se aproxima do centro, mais a presença fortalece-se". Quanto maior for a ação do objeto ao qual a afetividade suscitada é dirigida, sua densidade de presença, maior será o seu impacto e mais intensa a reação do sujeito da percepção e vice-versa; o que faz a partilha do sofrimento ser superior na interação entre o enunciatário-leitor e Miguilim, e menor na relação afetiva dele com Tiãozinho.

Ademais, na passagem de "Campo Geral", as figuras aparecem, tal como acontece em outros momentos da narração referente ao acidente e à morte de Dito, sobre contradições, choques e sobreposições, intensificando a oposição entre os valores de vida e morte e tornando patente para o enunciatário-leitor os efeitos tensivos produzidos - o que acontece de maneira átona e bastante difusa no trecho de "Conversa de bois". 0 acesso aos valores fica, como se pode ver, mediatizado pelo modo próprio de composição da figurativização e tematização, que, dirigindo a percepção, e a partir dela a assimilação do conteúdo e dos valores a ele subjacentes, resulta - na fase da moralização - em diferentes graus de afetividade, de interação.

Na história de Tiãozinho, a perspectiva adotada distribui a intensidade ao longo da exposição, enfraquecendo a tensão entre os valores em jogo e, por conseguinte, o impacto dela sobre o enunciatário-leitor, sobre a interação afetiva estabelecida com Tiãozinho. Há como uma operação de mistura e totalização axiológicas, mais próxima dos valores de universo, que promovem um compadecimento mais átono e inteligível, inferido do conjunto figurativo e temático global do ocorrido. 0 acento de sentido que incita a afetividade recaí, portanto, não sobre a figura específica de Tiãozinho, mas no papel temático por ele representado, o de um menino de oito anos, uma criança, já passando por tantos 
sofrimentos.

Na de Miguilim, ela revela o passional em toda a sua força, concentrado e associado à triagem axiológica, aos valores de absoluto. A interação afetiva entre o enunciatário-leitor e Miguilim, bem como a intensidade que a caracteriza, são resultados da tonicidade perceptiva e da exclusividade deste último no campo de presença do segundo. 0 pesar, advindo da percepção direta da angústia e do sofrimento visivelmente manifestados, provém de um sentir mesmo a dor do outro, um "sentir com", que privilegia não o papel temático da personagem, mas o padecimento em si; ou seja, o enternecimento provocado é dirigido especificamente a Miguilim, a sua dor pela perda do irmão, e não à figura da criança de um modo geral, que não deveria, por sua inocência e puerilidade, passar por uma situação assim.

A propósito dos procedimentos de textualização, nas duas narrativas analisadas as especificidades da manifestação textual são exploradas de modo a criar uma analogia íntima entre a linguagem e a construção da interioridade das personagens, permitindo maior cumplicidade entre os sujeitos do enunciado, as personagens e o sujeito da enunciação, o enunciatário-leitor. Segundo enfatiza Pedro Xisto (1983, p. 119): “Os vocábulos do nosso romancista-poeta, não se restringem a contar uma estória. Eles têm, ainda, o que contar de si próprios. Eles são mais do que signos abstratos e indiferentes. Eles integram a coisa, participando, concretamente, das vivências".

Sem dúvida, uma das características marcantes do discurso rosiano é a ressignificação do conteúdo discursivo no plano da expressão, no trabalho artístico, poético, com a linguagem verbal. Rosa inventa para sugerir e, na passagem do plano de conteúdo ao plano de expressão, isto é, na textualização, reinventa o sentido na materialidade textual para sugerir mundos, para sensibilizar o cenário criado no plano do conteúdo. Seus discursos acabam tendo um "sentidoalém"; à superfície textual sobrepõe-se um sentido outro, mais denso e abstrato, que atinge o enunciatário-leitor e o intriga, levando-o a compartilhar as emoções dos atores do enunciado.

A linguagem rosiana, ao explorar ao máximo as potencialidades latentes 
dentro do sistema da língua portuguesa, o seu valor expressivo, cria um entrelaçamento do narrativo com o poético, e, assim, as palavras e as sentenças que elas preenchem expressam sempre muito mais do que o sentido ordinário que têm na linguagem corrente, “apresentando o máximo de significado no mínimo de significante" (XISTO, 1983, p. 132).

Os estados de alma, a subjetividade das personagens e da própria história contada emergem, pois, do ritmo vivo e ondulante da prosa poética de Rosa, na qual os recursos de pontuação, a organização sintática das frases, as orações condensadas e as construções elípticas, bem como os neologismos, rimas e aliterações, ajudam a enfatizar o sentido já dado no plano de conteúdo e possibilitam ao enunciatário-leitor assimilar mais claramente, quando não, a partilhar de fato as tensões e emoções que exprimenta a personagem.

Atentemos às passagens a seguir para melhor compreender como isso acontece:

Enlameado até à cintura, Tiãozinho cresce de ódio. Se pudesse matar o carreiro... Deixa eu crescer!... Deixa eu ficar grande!... Hei de dar conta deste danisco... Se uma cobra picasse seu Soronho... Tem tanta cascavel nos pastos... Tanta urutu, perto de casa... Se uma onça comesse o carreiro, de noite... Um onção grande, da pintada... Que raiva!... (ROSA, 2001, p. 348)

A mãe não se lembrava, não podia repetir as palavras certas, falara na ocasião qualquer coisa, mas, o que, já não sabia. Ele mesmo, Miguilim, nunca tinha reparado antes nos cabelos, no narizinho do Dito. Então, ia para o paiol, e chorava, chorava. Depois, repetia, alto, imitando a voz da mãe, aquelas frases. Era ele quem precisava de guardá-las, decoradas, ressofridas; se não, alguma coisa de muito grave e necessária para sempre se perdia. (ROSA, 1996, p. 113; grifo nosso)

Em ambos os excertos, não só os recursos de pontuação, mas também a distribuição do conteúdo nas orações, conferem uma certa cadência, um certo ritmo que se associa à informação veiculada e combina com ela, pondo em evidência a carga emocional estabelecida.

No primeiro trecho, as frases curtas e pontuais, ao lado do uso de reticências para marcar as pausas, ultrapassam a organização linguística do conteúdo, 
acentuando e exprimindo o estado de alma da personagem, a cólera e a revolta que caracterizam seu momento de reflexão interiorizada. Cria-se um tom passional. As paixões que animam Tiãozinho naquele instante não são explicitadas no conteúdo discursivo, mas emergem da textualização, do modo próprio de utilizar os recursos linguísticos, que não só cumprem a sua função gramatical, mas também ressaltam, (re)criam a intensidade da tensão interior vivida pelo garoto.

Assim, mesmo com o enunciatário-leitor dirigido, no plano de conteúdo, por uma estratégia de orientação discursiva dominantemente cognitiva que o faz dar mais atenção às informações apresentadas pelas lembranças do pequeno guia, que o ajudam a compreender melhor os fatos apresentados anteriormente sem maiores esclarecimentos, ainda assim ele é sensibilizado pela passionalidade emergente da própria escritura, da manifestação textual do conteúdo. Mais do que o conteúdo enunciado, é o trabalho (poético) com a linguagem que patemiza a interação entre eles.

0 fragmento seguinte, por sua vez, fala do medo de Miguilim diante a possibilidade de perder a lembrança do irmão morto. Com o passar do tempo, a dor e o sofrimento iam diminuindo e ele via nisso uma forma de esquecimento. Do mesma maneira como acontece em "Conversa de bois", essa ideia, no entanto, não está explicitada no discurso, mas subjaz a ele pela textualização. Tanto as palavras escolhidas, como a pontuação, o conjunto do texto, levam a esse sentido: a repetição do verbo chorar ("e chorava, chorava") traz à tona a intensidade e a duratividade da ação; a pontuação dispensável do ponto de vista gramatical ("Depois, repetia, alto, imitando...") potencializa a atitude descrita e imprime um ritmo mais lento à leitura, atribuindo uma ênfase prosódica aos vocábulos separados por ela, o que acaba por acrescentar nuances de sentido àquele já dado pelo conteúdo. As palavras "decoradas" e "ressofridas" sublinham o sentido do que não pode ser esquecido, do sofrimento que precisa ser revivido e, por isso mesmo, são colocadas no texto de forma a enfatizar, intensificando, a passionalidade de seu conteúdo semântico, não apenas para descrever a emoção, mas para torná-la patente.

A língua, ao ser usada muito além de sua função utilitária, para além da 
mera manifestação do conteúdo, torna-se um vínculo e cria maior cumplicidade entre o enunciatário-leitor e os atores do enunciado, as personagens. A escrita rosiana opera, por isso mesmo, sobre o modo da subjetividade, da intensidade dos seres e das situações que configuram seu discurso. Ela traz à cena a sensibilidade do protagonista, a sua reflexão e o seu posicionamento sobre os acontecimentos e a realidade circundante. Os estados passionais dos atores do enunciado são, nesse sentido, recriados na expressão, convocando o enunciatário-leitor a uma percepção mais sensível do conteúdo e dos valores transmitidos. Como explica Coutinho (1994, p. 216):

A pontuação de Guimarães Rosa, tópico fundamental no que diz respeito ao seu estilo, é muito mais estética do que propriamente ortográfica. Embora não chegue a desprezar completamente as regras gramaticais da língua portuguesa, não hesita em violar tais preceitos sempre que se tornam um empecilho para a expressão da emotividade.

A dimensão passional da narrativa é recriada, portanto, na textualização, pela forma como a linguagem verbal é articulada e pelo ritmo que se cria a partir disso. Cada palavra escolhida, cada forma de articulá-la dentro do discurso, confere existência concreta a um sentido que estava até então em estado potencial, fazendo com que à história contada sobreponha-se uma significação outra, mais sensível, mais patemizada. 0 conteúdo semântico dos vocábulos e das sentenças é explorado de modo que sua carga passional se ofereça à percepção do enunciatário-leitor, e, assim, o sentido passa a ser vivido, a ser experimentado, articulando o inteligível ao sensível.

\subsubsection{Considerações sobre os resultados da análise}

O exame detalhado dos procedimentos de discursivização e textualização dos dois enunciados mostrou que a relação patêmica entre o enunciatário-leitor e os atores do enunciado está, nas duas narrativas, de fato, intimamente relacionada à maneira como as modulações tensivo-fóricas - próprias à coexistência dos 
valores que envolvem o sofrimento das personagens - concentram-se ou distribuem-se através da figuratividade. Assim, embora a estruturação semântica seja bastante parecida, os textos analisados, divergindo nas estratégias de composição discursiva, estabelecem com o enunciatário-leitor diferentes modos de interação afetiva, de configuração do pesar.

No primeiro conto, "Conversa de bois", o jogo entre um presente difuso e um passado que é preciso compreender faz com que o vínculo interactancial entre sujeito da percepção e objeto-valor da afetividade tenha intersubjetividade átona. Mesmo com a (re)criação de uma passionalidade que emerge da textualização, a intensidade discursiva distribui-se na extensão figurativa, por ser a partir dela que o enunciatário-leitor obtém as informações necessárias ao entendimento global do acontecido (fase da sensibilização), daquilo que causa o sofrimento do menino.

Os valores subjacentes ao padecimento de Tiãozinho emergem, dessa forma, do desdobramento narrativo da situação vivida e retomada pela lembrança, da sua postura crítica sobre o sucedido e das paixões suscitadas e recriadas na textualização. Seu sofrimento não está claramente figurativizado no discurso, procedendo da dimensão figurativa responsável pela concretização do que é lembrado. O enunciatário-leitor, tendo acesso só então ao ocorrido, precisa primeiro compreender o que houve, sancionar os fatos, para, então, poder interagir com a subjetividade posta em cena. A sensibilização própria à produção do pesar provém, nesse sentido, principalmente de uma mistura axiológica, de um inferir, um imaginar o sofrimento de Tiãozinho através da (re)construção dos fatos, o que assinala a assimetria de lugares, a afetividade produto do "valor do valor", na qual prepondera uma interpretação inteligível, moralizante, um "sentir por" (fase da moralização).

Na segunda narrativa analisada, "Campo geral”, ao contrário, a ênfase é dada justamente à sensibilidade de Miguilim, com a figuratividade concretizando a sua interioridade pueril e criando, por conseguinte, uma maior cumplicidade entre ele e o enunciatário-leitor, constantemente sensibilizado pela tonicidade advinda do conteúdo narrado e intensificada nos procedimentos de textualização. Os valores concentram-se em um campo de presença de intensidade tônica e extensidade 
restrita, em especial na cena referente à morte de Dito, cujas figuras concentram-se no sofrimento visivelmente observável de Miguilim (fase da sensibilização), deixando o entorno em segundo plano. 0 enunciatário-leitor sabe a dor que o ator do enunciado está vivendo, ele a "presencia" e, desse modo, compartilha mesmo a sua angústia, o seu desespero. Daí o pesar sentido resultar de uma interação mais simétrica, direta, e, por isso, de maior impacto estésico, de maior convocação sensível; o que consolida uma interpretação de caráter mais emocional, um "sentir com", de fato (fase da moralização).

A estratégia de gerenciamento da convocação sensível-inteligível do enunciatário-leitor é, portanto, como pensávamos, a peça-chave na configuração da interação afetiva entre ele e os atores do enunciado, ou, mais abstratamente, entre o sujeito que percebe e o objeto-valor da afetividade. Parece confirmar-se, então, a hipótese de que são as circunstâncias de desenvolvimento da atividade perceptiva as responsáveis pelo modo de articulação do sensível com o inteligível e pela dominância de cada um deles na instauração das relações afetivas.

Além disso, tal como havíamos proposto, a análise realizada comprova que o efeito passional de compaixão é resultado de uma interação direta entre o sujeito da percepção e o objeto-valor da afetividade, com o acento de sentido recaíndo exclusivamente sobre este último; já no caso da piedade, as modulações tensivas privilegiam a apreensão dos entornos, da situação que faz sofrer, estabelecendo uma relação indireta, porque mediada, entre os actantes da interação. De qualquer maneira, seguiremos com nossas análises, a partir do exame de dois outros textos, agora de autores diferentes, para ver se a coerência dessa ideia continua a se sustentar.

\section{3 “Negrinha”, de Monteiro Lobato: horror, piedade e compaixão}

Ávido e crítico leitor, Monteiro Lobato concede a seu enunciatário toda a atenção. Submetendo a escrita à leitura, o autor preocupa-se com a experiência estética, com a articulação da "forma" e das "ideias", do "dito" e da "maneira de 
dizer", "tudo devendo estar voltado para a obtenção de um efeito que surpreenda o leitor" (BECKER, 2006, p. 34). Conforme explica o próprio escritor:

É mister que venham de braço dado e em perfeito pé de perfectibilidade. Há pelo norte uns escritores de talento que só querem saber da ideia e deixam a forma p'r'ali. Eu também já pensei assim - que a ideia era tudo e a forma um pedacinho. Mas apesar de pensar assim, não conseguia ler os de belas ideias embrulhadas em panos sujos. Por fim me convenci do meu erro e estou a penitenciar-me. Impossível boa expressão duma ideia se não com ótima forma. Sem limpidez, asseio de forma, a ideia vem embaciada, como copo mal lavado. E o pobre leitor vai tropeçando - vai dando topadas na má sintaxe, extraviando-se nas obscuridades e nas impropriedades. (LOBAT0, 1951, vol. 11, p. 22)

Com efeito, no conto "Negrinha", "ideia" e "forma" - entendidas por nós como o "dito" e a "maneira de dizer" - entrelaçam-se "em perfeito pé de perfectibilidade". 0 modo de compor a estória é, como veremos, cautelosamente trabalhado, enriquecendo e ampliando a força do narrado através de efeitos de sentido que acometem o enunciatário-leitor e o fazem participar da narrativa de forma ativa e apaixonada.

Assim, mesmo que o enunciado se configure em um ele-lá-então, o efeito de objetividade, de alteridade em relação à situação narrada, enfraquece-se e dá lugar à possibilidade de um posicionamento passional, proveniente de um processo de sensibilização tônica por parte do enunciador. A própria narração em terceira pessoa é subjetiva e demonstra, sobretudo pelo tom oral e irônico adotado, certa interação afetiva com o narrado. A enunciação enunciada assume, pois, na figura de um narrador sarcástico, um papel tão importante quanto o das personagens. Ele não apenas conta a estória, mas a sanciona, toma uma posição crítica, guiando a sensibilidade do enunciatário-leitor, seu narratário, e levando-o a apreender, sensível e inteligivelmente, o conteúdo do enunciado, a refletir sobre a ideia ali apresentada, como mostram os trechos a seguir:

Que ideia faria de si essa criança que nunca ouvira uma palavra de carinho? Pestinha, diabo, coruja, barata descascada, bruxa, patachoca, pinto gorado, mosca-morta, sujeira, bisca, trapo, cachorrinha, coisa-ruim, lixo - não tinha conta o número de apelidos com que a mimoseavam. Tempo houve em que foi a 
bubônica. A epidemia andava na berra, como a grande novidade, e Negrinha viu-se logo apelidada assim - por sinal que achou linda a palavra. Perceberam-no e suprimiram-na da lista. Estava escrito que não teria um gostinho só na vida - nem esse de personalizar a peste... (p. 79)

Varia a pele, a condição, mas a alma da criança é a mesma - na princesinha e na mendiga. E para ambos é a boneca o supremo enlevo. Dá a natureza dois momentos divinos à vida da mulher: 0 momento da boneca - preparatório -, e o momento dos filhos definitivo. Depois disso, está extinta a mulher. (LOBATO, 2009, p. 83)

Com uma estrutura narrativa aparentemente simples e sucinta, o conto pode ser dividido em três grandes etapas bem marcadas: (i) um estado inicial, cuja caracterização causa horror e piedade no enunciatário-leitor; (ii) uma transformação, a partir da qual se fortalece o vínculo com a personagem central, fazendo a piedade ("sentir por") transforma-se em compaixão ("sentir com"); e (iii) um estado final, no qual se consolida a sanção, a interpretação moralizante. Paralelo a esse percurso patêmico do enunciatário-leitor, originário no momento da leitura a partir dos efeitos produzidos no e pelo próprio enunciado, estabelecese um outro, também diretamente ligado às "etapas" da estrutura narrativa e com influência direta sobre a interação afetiva construída, mas que diz respeito, como veremos, à construção (existencial), condicionada à densidade de presença da personagem Negrinha no conjunto do discurso.

A estória se inicia com a apresentação dos atores do enunciado e já nesse momento se indiciam as forças em conflito, a oposição axiológica de base que "animará" a narrativa.

Negrinha era uma pobre órfã de sete anos. Preta? Não; fusca, mulatinha escura, de cabelos ruços e olhos assustados.

Nascera na senzala, de mãe escrava, e seus primeiros anos viveraos pelos cantos escuros da cozinha, sobre velha esteira e trapos imundos. Sempre escondida, que a patroa não gostava de crianças. Excelente senhora, a patroa. Gorda, rica, dona do mundo, amimada dos padres, com lugar certo na igreja e camarote de luxo reservado no céu. Entaladas as banhas no trono (uma cadeira de balanço na sala de jantar), ali bordava, recebia as amigas e o vigário, dando audiências, discutindo o tempo. Uma virtuosa senhora em suma - "dama de grandes virtudes apostólicas, esteio 
da religião e da moral", dizia o reverendo.

Ótima, a dona Inácia.

Mas não admitia choro de criança. Ai! Punha-lhe os nervos em carne viva. Viúva sem filhos, não a calejava o choro da carne de sua carne, e por isso não suportava o choro da carne alheia. Assim, mal vagia, longe, na cozinha, a triste criança, gritava logo nervosa:

- Quem é a peste que está chorando aí?

Quem havia de ser? A pia de lavar pratos? 0 pilão? 0 forno? A mãe da criminosa abafava a boquinha da filha e afastava-se com ela para os fundos do quintal, torcendo-lhe em caminho beliscões de desespero.

- Cale a boca, diabo!

No entanto, aquele choro nunca vinha sem razão. Fome quase sempre, ou frio, desses que entangem pés e mãos e fazem-nos doer... (LOBATO, 2009, p. 78-79)

Dois estados contrastantes se chocam: um de pobreza e subserviência, outro de riqueza e soberania. A apresentação de Negrinha, uma primeira estratégia de sensibilização, toca o enunciatário-leitor porque as condições em que ela vive são totalmente contrárias às que se espera para uma criança - mesmo sendo ela uma pequena escrava. Não bastasse isso, a descrição ironizada de D. Inácia salienta a ausência de sensibilidade na "dama de grandes virtudes apostólicas, esteio da religião e da moral" (p. 78), na qual Negrinha deveria encontrar algum conforto. Colocada já nesse preâmbulo da estória, essa manifestação concessiva dos valores semântico-ideológicos em jogo, advindos da mistura axiológica entre os que investem a figura da menina e aqueles provenientes do entorno, da situação retratada, rompe com o esperado para tais papéis temáticos, e o enunciatárioleitor, ao inferir-lhe a vida dura e de grande sofrimento, passa a "sentir por" Negrinha.

A narração continua detendo-se agora a descrever o cotidiano da pobre garota, e o narrador esmera-se em fornecer todas as indicações necessárias para caracterizar de maneira adequada a atitude de extrema crueldade com que a tratavam. 0 enuciatário-leitor, já inicialmente sensibilizado, vai, então, pouco a pouco sendo apanhado pelo horror da situação tal como se configura.

Com pretextos de que às soltas reinaria no quintal, estragando as plantas, a boa senhora punha-a na sala, ao pé de si, num desvão da porta. 
- Sentadinha aí, e bico, hein?

Negrinha imobilizava-se no canto, horas e horas.

- Braços cruzados, já, diabo!

Cruzava os bracinhos a tremer, sempre com o susto nos olhos. [...]

O corpo de Negrinha era tatuado de sinais, cicatrizes, vergões.

Batiam nele os da casa todos os dias, houvesse ou não houvesse motivo. Sua pobre carne exercia para os cascudos, cocres e beliscões a mesma atração que o ímã exerce para o aço. Mãos em cujos nós de dedos comichasse em cocre, era mão que se descarregaria dos fluidos em sua cabeça. De passagem. Coisa de rir e ver a careta... [...]

Cocres: mão fechada com raiva e nós de dedos que cantam no coco do paciente. Puxões de orelha: o torcido, de despegar a concha (bom! Bom! Bom! gostoso de dar) e o a duas mãos, o sacudido. A gama inteira dos beliscões: do miudinho, com a ponta da unha, à torcida do umbigo, equivalente ao puxão de orelha. A esfregadela: roda de tapas, cascudos, pontapés e safanões a uma divertidíssimo! A vara de marmelo, flexível, cortante: para "doer fino" nada melhor!

[...] Lá de quando em quando vinha um castigo maior para desobstruir o fígado e matar as saudades do bom tempo. Foi assim com aquela história do ovo quente.

Não sabem! Ora! Uma criada nova furtara do prato de Negrinha coisa de rir - um pedacinho de carne que ela vinha guardando para o fim. A criança não sofreou a revolta - atirou-lhe um dos nomes com que a mimoseavam todos os dias.

- "Peste?" Espere aí! Você vai ver quem é peste - e foi contar o caso à patroa.

Dona Inácia estava azeda, necessitadíssima de derivativos. Sua cara iluminou-se.

- Eu curo ela! - disse, e desentalando do trono as banhas foi para a cozinha, qual perua choca, a rufar as saias.

- Traga um ovo.

Veio o ovo. Dona Inácia mesmo pô-lo na água a ferver; e de mãos à cinta, gozando-se na prelibação da tortura, ficou de pé uns minutos, à espera. Seus olhos contentes envolviam a mísera criança que, encolhidinha a um canto, aguardava trêmula alguma coisa de nunca visto. Quando o ovo chegou a ponto, a boa senhora chamou:

- Venha cá!

Negrinha aproximou-se.

- Abra a boca!

Negrinha abriu a boca, como o cuco, e fechou os olhos. A patroa, então, com uma colher, tirou da água "pulando" o ovo e zás! Na boca da pequena. E antes que o urro de dor saísse, suas mãos amordaçaram-na até que o ovo arrefecesse. Negrinha urrou surdamente, pelo nariz. Esperneou. Mas só. Nem os vizinhos chegaram a perceber aquilo. Depois:

- Diga nomes feios aos mais velhos outra vez, ouviu, peste? (LOBATO, 2009, p. 79-81, grifo nosso) 
A alta densidade de presença dos valores disfóricos na conduta de D. Inácia chama a atenção para a ausência dos valores eufóricos próprios à caridade e à piedade tão mencionadas por ela. Ao atuar como inflexão de tonicidade, a descrição detalhada da maldade gratuita contra Negrinha configura-se em um percurso de intensidade ascendente que culmina com a "história do ovo quente". As figuras desse trecho, sem expandir os horizontes do campo de presença estabelecido entre o enunciatário-leitor e aquilo que lhe é contado, recrudescem o quantum de crueldade retratado, o que concentra a intensidade e dá à situação narrada, ao entorno, o valor de acontecimento.

Essa estratégia qualitativa própria ao ponto de vista eletivo, em detrimento da quantidade e de uma perspectiva cumulativa, "apoia-se no impacto de uma apreensão seletiva, no valor representativo da amostra eleita" (FONTANILLE, 1999, p. $48^{76}$ ). Como explica Fontanille (Idem, $i{ }^{2} d^{77}$ ):

As duas estratégias pressupõem uma fragmentação do objeto em partes, e tentam uma recomposição da totalidade a partir das partes. Para a primeira [estratégia quantitativa], a totalidade seria recomposta a partir da sucessão e da soma das partes [...]. Para a segunda estratégia [qualitativa], a totalidade seria alcançada graças ao valor prototípico de uma das partes, na qual o caráter de amostra representativa dispensaria a necessidade de examinar todas as outras $[\ldots]$

Assim, o desdobramento figurativo, ao operar como um processo de iconização da impiedade, rompe totalmente com o esperado e, por isso mesmo, choca e horroriza o leitor, levando-o quase a sentir na própria carne o sofrimento, a dor da personagem. De toda maneira, a intensidade gerada por essa descrição coloca o acento de sentido na atrocidade da situação, do comportamento da Sinhá, e não exatamente em seu impacto sobre Negrinha, que, resignada a sua condição de "coisa", sujeita-se à barbárie de forma passiva - como mostram os trechos grifados.

76 Trecho original: "[...] repose sur l'éclat d'une visée sélective, sur la valeur représentative de l'échantillon retenu."

77 Trecho original: "Les deux stratégies préssupposent en fait une fragmentation de l'objet en parties, et tentent une recomposition de la totalité a partir des parties. Pour la première [stratégie quantitative], la totalité serait recomposée a partir de la succession et de la somme des parties [...]. Pour la seconde stratégie [qualitative], la totalité serait approchée d'échantillon représentatif dispenserait d'examiner toutes les autres [...] 
Embora em alguns momentos a apreensão do que se passa seja sensível, quando a descrição, ao explorar o máximo de precisão icônica, de efeito veridictório, chega a ter grande apelo estésico, permitindo ao enunciatário-leitor prever claramente as sensações, a repercussão da atitude sobre Negrinha, o elo afetivo entre eles permanece caracterizado como um "sentir por" piedoso. Isso porque, sem indicações explícitas do que se passa em seu íntimo, o sofrimento vivido por ela é inferido, imaginado a partir de um posicionamento moralizante do acontecido, sobre o qual recai o acento de sentido.

A interação afetiva entre o sujeito que sofre e o sujeito que testemunha esse sofrimento não é, portanto, direta, ela é mediada pela situação em questão. Firmase, assim, uma aproximação entre o enunciatário-leitor e Negrinha, levando-o a se compadecer dela; mas não há, nesse caso, uma fusão interactancial própria à compaixão, ao "sentir com". É a partir do entorno figurativizado no campo de presença estabelecido pela atividade de leitura que o sujeito da percepção, em um posicionamento de natureza preponderantemente inteligível, pode deduzir o padecimento alheio.

A passividade de Negrinha diante esse comportamento que a coisifica ${ }^{78}$ e a falta de conhecimento do seu sofrimento interior conservam a assimetria de lugares, e, desse modo, embora o enunciatário-leitor possa sentir como ela, nessas circunstâncias não o sente com ela. A subjetividade evocada é produto da apreensão do evento, e não da interação direta estabelecida com a personagem. Apoiando-se, então, em seu próprio ponto de vista, sensível e inteligível, sobre a circunstância narrada, o padecimento pelo qual passa a menina é deduzido, e o crer-saber, que configura o pesar suscitado, permanece, pois, aderido. Isso muda, no entanto, no momento da "história do ovo quente" - ponto máximo da vilania, clímax da impiedade.

Sempre atento àquele a quem a história se dirige e aos efeitos que o devem assaltar, o narrador conduz a explanação do relato desse episódio de forma a provocar no enunciatário-leitor a mesma tensão prévia pela qual passa a pequena.

78 Coisificar: 1 tornar parecido com uma coisa; identificar com um ato ou objeto concreto [...] 2 reduzir o homem e sua consciência a coisa, objeto ou valores materiais [...] 2.1 tratar o ser humano desse modo. (Dicionário HOUAISS, 2009, p. 490) 
Os elementos vão sendo dados um a um - a truculência e a falta de humanidade já conhecidos, o ovo, a água quente, o prazer nos olhos -, e isso alonga e tonifica a espera agora patemizada. A certeza de um porvir disfórico é, pois, partilhada. Nesse instante, personagem e leitor são um só, ambos tomados pela tensão e pelo medo. A interação entre eles é direta, imediata, e por isso, quando enfim chega o atroz castigo, explode o pesar do enunciatário-leitor, que, em plena sincronização sensível com Negrinha, "sente com" ela.

Com o acento de sentido recaindo desta vez sobre a tensão prévia, sobre o pavor que aos poucos se configura para ambos, essa primeira fusão entre enunciatário-leitor e ator do enunciado intensifica a interação entre eles, como se a assimetria de lugares antes bem demarcada se dissolvesse e certa cumplicidade se estabelecesse. A perspectiva narrativa também se modifica, e o narrador passa agora a dar maior realce à interioridade da personagem, aos valores que daí emanam, com as situações apresentadas do ponto de vista de Negrinha. A ênfase antes dada à situação narrada incide, a partir de então, mais exclusivamente sobre a figura da menina, sobre sua subjetividade, e possibilita uma interação mais direta entre ela e o enunciatário-leitor. Ademais, ao adotar esse tipo de representação mais subjetiva dos fatos, a figura se particulariza, pois não se trata mais de uma criança apenas (valores de universo), mas de Negrinha (valores de absoluto).

Como acontecerá no próprio conteúdo narrativo, tem início, também para o enunciatário-leitor, o processo de humanização da personagem. Sua ingenuidade pueril, apenas latente anteriormente, vem à tona com mais força e sensibiliza ainda mais a narrativa, transformando o "sentir por" piedoso em um "sentir com" compassivo.

Certo dezembro vieram passar as férias com Santa Inácia duas sobrinhas suas, pequenotas, lindas meninas louras, ricas, nascidas e criadas em ninho de plumas.

Do seu canto na sala do trono, Negrinha viu-as irromperem pela casa como dois anjos do céu - alegres, pulando e rindo com a vivacidade de cachorrinhos novos. Negrinha olhou imediatamente para a senhora, certa de vê-la armada para desferir contra os anjos invasores o raio dum castigo tremendo.

Mas abriu a boca: a sinhá ria-se também... Quê? Pois não era crime brincar? Estaria tudo mudado - e findo o seu inferno - e aberto o 
céu? No enlevo da doce ilusão, Negrinha levantou-se e veio para a festa infantil, fascinada pela alegria dos anjos.

Mas a dura lição da desigualdade humana lhe chicoteou a alma. Beliscão no umbigo, e nos ouvidos, o som cruel de todos os dias: "Já para o seu lugar, pestinha! Não se enxerga?"

Com lágrimas dolorosas, menos de dor física que de angústia moral - sofrimento novo que se vinha acrescer aos já conhecidos a triste criança encorujou-se no cantinho de sempre. (LOBATO, 2009, p. 81, grifo nosso)

Nesse trecho, a inocência de Negrinha emerge com toda a sua intensidade e tonifica tanto a oposição entre os valores semânticos manifestados pela descrição das meninas, totalmente contrastante àqueles que caracterizam a pobre órfã, quanto a interação afetiva estabelecida entre ela e o enunciatário-leitor. A tensão produzida pela constatação da ingenuidade da pequena patemiza a compreensão do enunciatário-leitor a propósito do impacto da atitude desalmada de D. Inácia sobre a timia da menina, que, da maneira mais cruel, dá-se conta da "dura lição da desigualdade humana" (p. 81). Aí se inicia o processo de conscientização de Negrinha.

Após ter retratado a crueldade e a hipocrisia de D. Inácia em toda a sua tonicidade, com a pobre órfã subjugada ao estatuto de coisa, a narração muda de rumo para enfatizar agora o íntimo de Negrinha, a descoberta de si mesma e o próprio horror em relação à maneira como era tratada. Sua inocência e ingenuidade entram em cena com maior destaque, chamando inclusive a atenção da própria personagem. A chegada das meninas dá início, assim, à transformação pela qual passará a menina, à sua humanização, assinalada na opção pelo uso do discurso indireto livre - estratégia privilegiada para a manifestação da interioridade dos atores do enunciado e o estabelecimento da cumplicidade entre eles e o enunciatário-leitor.

- Brinquem! Brincar! Como seria bom brincar! - refletiu com suas lágrimas, no canto, a dolorosa martirzinha, que até ali só brincara em imaginação com o cuco.

[...]

Que maravilha! Um cavalo de pau!... Negrinha arregalava os olhos. Nunca imaginara coisa assim tão galante. Um cavalinho! E mais... Que é aquilo? Uma criancinha de cabelos amarelos... que falava "mamã"... que dormia... (LOBATO, 2009, p. 81-82) 
Nesse processo de conscientização, o elo entre ela e o enunciatário-leitor se solidifica, porque o crer-saber passa a ser assumido. 0 sofrimento não é mais inferido, ele é manifestado e pode, por isso mesmo, ser compartilhado. Essa cumplicidade estabelecida é - tal como aconteceu "na história do ovo quente" claramente explorada no momento ápice desse percurso de descoberta, mostrando, mais uma vez, a maestria do narrador para garantir a participação ativa de seu enunciatário, o seu envolvimento afetivo com a estória narrada.

E dominada pelo enlevo, num momento em que a senhora saiu da sala a providenciar sobre a arrumação das meninas, Negrinha esqueceu o beliscão, o ovo quente, tudo, e aproximou-se da criatura de louça. Olhou-a com assombrado encanto, sem jeito, sem ânimo de pegá-la. [...]

- Pegue!

Negrinha olhou para os lados, ressabiada, com o coração aos pinotes. Que ventura, santo Deus! Seria possível? Depois pegou a boneca. E muito sem jeito, como quem pega o Senhor menino, sorria para ela e para as meninas, com assustados relanços de olhos para a porta. Fora de si, literalmente... era como se penetrara no céu e os anjos a rodeassem, e um filhinho de anjo lhe tivesse vindo adormecer ao colo. Tamanho foi o seu enlevo que não viu chegar a patroa, já de volta. Dona Inácia entreparou, feroz, e esteve uns instantes assim, apreciando a cena.

Mas era tal a alegria das hóspedes ante a surpresa extática de Negrinha, e tão grande a força irradiante da felicidade desta, que o seu duro coração afinal bambeou. E ela pela primeira vez na vida foi mulher. Apiedou-se.

Ao percebê-la na sala Negrinha havia tremido, passando-lhe num relance pela cabeça a imagem do ovo quente e hipóteses de castigos ainda piores. $\mathrm{E}$ incoercíveis lágrimas de pavor assomaram-lhe aos olhos.

Falhou tudo isso, porém. 0 que sobreveio foi a coisa mais inesperada do mundo - estas palavras, as primeiras que ela ouviu, doces, na vida:

- Vão todas brincar no jardim, e vá você também, mas veja lá, hein?

Negrinha ergueu os olhos para a patroa, olhos ainda de susto e terror. Mas não viu mais a fera antiga. Compreendeu vagamente e sorriu. (LOBATO, 2009, p. 82-83)

Se Negrinha é dominada pelo deslumbramento causado pela boneca, esquecendo os beliscões, o ovo quente e toda a vilania da Sinhá, o enunciatárioleitor tem ainda vivo tudo isso em sua memória e, por isso mesmo, desespera-se por ela e por sua ousadia em desafiar a própria sorte. Instaura-se, desse modo, uma 
aceleração antecipadora que converte o "não ainda" em um "já" fantasmático (ZILBERBERG, 2006) que passionaliza o desenrolar da ação pela criação de certo suspense, uma espera expectante do porvir disfórico.

Todavia, a descrição detalhada do êxtase da pequena, dirigida pelo procedimento textual de expansão, desacelera o evento e atenua a tensão criada, permitindo ao leitor a partilha da emoção de Negrinha, de seu encantamento neste momento de epifania. Com a duração da narração sendo maior que a do narrado, do tempo da ação, cria-se uma suspensão da expectativa disfórica em prol da beleza daquele instante. Mas a aparição de D. Inácia os faz despertar do enlevo, provocando o susto, o medo e mesmo o pânico, primeiro para o enunciatário-leitor, a quem a informação é dada antecipadamente - "Tamanho foi o seu enlevo que não viu chegar a patroa, já de volta." (p. 82) - e depois para a personagem.

Ao jogar, no plano textual, com a sequência cronológica dos fatos, o narrador, antes de descrever o que sentira a menina ao se dar conta da presença da "boa senhora", continua a explorar o pânico evocado no enunciatário-leitor, levando-o a sentir os acontecimentos como se fizesse parte deles, tal como a pobre órfã. Uma vez tomado pelo medo do castigo fácil de ser previsto, ele fica, portanto, surpreso com a atitude concessiva da Sinhá, que "pela primeira vez na vida foi mulher. Apiedou-se." (p. 82).

A partilha desse momento de angústia é constatada quando o narrador enfim relata o que se passara no íntimo de Negrinha ao ser "pega em flagrante": "Ao percebê-la na sala Negrinha havia tremido, passando-lhe num relance pela cabeça a imagem do ovo quente e hipóteses de castigos ainda piores." (p. 82, grifo nosso). A descrição da surpresa da menina se apresenta, então, para o enunciatário-leitor que há pouco vivera a mesma sensação de pânico, como uma constatação da cumplicidade firmada entre eles. A opção pelo uso do passado mais que perfeito, nesse trecho, reafirma a sincronia passional anteriormente estabelecida.

O comportamento surpreendente de D. Inácia, além disso, tonifica e, consequentemente, sensibiliza ainda mais aquele instante do contato com a boneca, deixando evidente "a força irradiante da felicidade" de Negrinha e a importância dele na transformação, na descoberta existencial da menina. Mas a 
continuação da narrativa, sempre aproveitando do poder de impacto da tensão entre contrários, instaura um paradoxo: a consciência da vida lhe traz a morte.

\begin{abstract}
Negrinha, coisa humana, percebeu nesse dia da boneca que tinha uma alma. Divina eclosão! Surpresa maravilhosa do mundo que trazia em si e que desabrochava, afinal, como fulgurante flor de luz. Sentiu-se elevada à altura de ente humano. Cessara de ser coisa - e doravante ser-lhe-ia impossível viver a vida de coisa. Se não era coisa! Se sentia! Se vibrava!

Assim foi - e essa consciência a matou.

[...]

Brincara ao sol, no jardim. Brincara!... Acalentara, dias seguidos, a linda boneca loura, tão boa, tão quieta, a dizer mamã, a cerrar os olhos para dormir. Vivera realizando sonhos da imaginação. Desabrochara-se de alma.

Morreu na esteirinha rota, abandonada de todos, como um gato sem dono. (LOBATO, 2009, p. 83)
\end{abstract}

A ligação concessiva entre os valores de vida e morte, além da força de sensibilização, leva o enunciatário a (re)viver a experiência de Negrinha, que, depois de sentir a vida em toda a sua plenitude, morre. Consciente da possibilidade de impacto pela combinação concessiva dos fatos, o narrador, ao explorar as modulações do andamento envolvidas no modo de inserção dos valores no campo de presença, inverte a sequência cronológica, a ordem dos acontecimentos, apresentando a consequência - na qual recai o acento de sentido - para somente depois explicar o "caminho" até ela. Ele extingue a extensidade e acelera a aparição do valor contrário, figurativizado pela morte de Negrinha, que aumenta, por conseguinte, a densidade do impacto sobre o enunciatário-leitor, para depois expandi-la, distendendo a tensão, em um movimento de restabelecimento.

Os procedimentos de textualização do conto, assentados sobretudo no princípio da elasticidade textual, convergem, dessa forma, para esse efeito de controle do andamento e do gerenciamento dos efeitos passionais produzidos, seja na utilização de frases curtas, em períodos diferentes, para expandir a espera expectante e criar o suspense, aumentando a tensão - como acontece nos dois momentos de maior sincronização sensível entre Negrinha e o enunciatário-leitor -, seja no uso da pontuação como recurso de ênfase para o sentido das ações descritas, das palavras escolhidas para a concretização da "ideia". Ou ainda na 
expansão da caracterização detalhada dos maus-tratos, quando o narrador interrompe a apresentação das ações para fazer um pequeno "glossário" dos castigos exercidos.

De qualquer maneira, adepto à concisão, à concentração da informação no que de fato importa, todas as escolhas e os recursos que marcam a escrita lobatiana têm, como vimos, um valor, um papel fundamental na produção dos efeitos de sentido buscados, na evocação da sensibilidade do enunciatário-leitor.

\subsubsection{Considerações sobre o resultado da análise}

Os dados levantados pela análise confirmam que só o exame do modo de convocação do sensível e do inteligível na emergência das interações patêmicas (modos primários de interação afetiva) não basta para compreender as condições de configuração dos estados de alma provocados (modos complexos de interação afetiva), podendo mesmo levar ao erro, a constatações precipitadas.

A estória, no conto "Negrinha", configura, durante toda a narrativa, um campo de presença entre o enunciatário-leitor e a personagem central (fase da constituição) de profundidade restrita, com concentração da tensão e convocação de uma participação dominantemente sensível. Mas, mesmo com o predomínio de uma profundidade circunscrita do campo de presença, própria à articulação centrípeta das valências, das modulações tensivas (fase da disposição), ainda assim, em um primeiro momento, instituiu-se uma interação afetiva de natureza mais inteligível, um "sentir por". Isso mostra que, mesmo nas interações afetivas assentadas no endereçamento inteligível ao outro, como é o caso da piedade, do "sentir por", pode haver grande incitação sensível do sujeito da percepção, importando, então, a grandeza a qual tal sensibilidade é dirigida (fase da sensibilização) - modo complexo de interação afetiva.

Fica comprovado, dessa forma, que é preciso atentar sobretudo a relação intrínseca que o figural estabelece com o figurativo, afinal, conforme assinala Zilberberg (2006, p. 131), "na dimensão do enunciado, a foria tem estatuto de 
caracterizante e a grandeza tratada, de constituinte. Do ponto de vista da imanência, a grandeza vale como pressuponente e a foria aparece como pressuposta". Ele acrescenta (Idem, ibid): "essa foria seria coextensiva aos conteúdos". Ou seja, é inextricável a ligação entre a dimensão figurativa e a dimensão figural (tensiva) no ato enunciativo, a partir do qual se dá a constituição do modo de presença do objeto-valor percebido e sua caracterização. A análise de um leva, pois, necessariamente à investigação da determinação efetuada no outro.

No caso específico das condições de configuração dos estados de alma de compaixão e piedade, por exemplo, ficou claro que, para além da convocação do sensível e do inteligível nos modos primários de interação afetiva, importa ainda mais o modo de existência, de presença, no campo tensivo, do objeto-valor ao qual a afetividade suscitada é dirigida, porque aí reside o fator determinante para o grau de envolvimento, a natureza qualitativa de um e outro afeto (modo complexo de interação afetiva). Além disso, mais uma vez se confirmou nossa hipótese de que na cena passional própria à realização do efeito de compaixão e piedade, a modulação tensiva incidirá sobre o "mau causador", no caso desta última, e diretamente sobre a "vítima", no que diz respeito à primeira.

No conto analisado, como vimos, a incidência do acento de sentido nas grandezas em jogo, responsável pela determinação do tipo de interação afetiva instituído (fase da patemização), muda no desenrolar do enunciado, fazendo variar o grau de envolvimento patêmico estabelecido entre o enunciatário-leitor e a menina. Na primeira parte da estória, referente à situação inicial do percurso narrativo de Negrinha, as modulações de intensidade, concentradas em um campo de extensidade reduzida, recaem sobre o cotidiano de extrema crueldade da pequena órfã, colocando, dessa forma, o acento de sentido nos entornos. A atenção do enunciatário-leitor volta-se, assim, mais para o "mal causador do sofrimento" do que para o padecimento da menina em si. Ele conhece as circunstâncias de forma bastante detalhada e, horrorizado, choca-se, indigna-se com a situação; e, então, "sente por" Negrinha.

Mesmo que a sensibilidade do enunciatário-leitor tenha sido especialmente convocada pela intensidade manifestada (fase da emoção), o envolvimento afetivo 
desenvolvido, nessa primeira parte da narrativa, é ainda átono. Não há um forte vínculo entre ele e a menina, que, apresentando-se como um dos elementos do entorno, opera uma mistura axiológica, perdendo em densidade de presença. Existe sim um pesar evocado pelos valores advindos da figura, do papel temático da criança, escrava, órfã, aproximando-os; mas o efeito patêmico regente da interação afetiva ainda é de caráter generalizante (valores de universo), uma vez que nenhuma criança deve viver assim, ser tratada de forma tão cruel.

Com a baixa densidade de presença de Negrinha, nessa primeira parte do conto, o sofrimento dela é inferido pelo enunciatário-leitor, deduzido a partir dos elementos apreendidos durante a explanação; daí o pesar suscitado configurar-se a partir de um raciocínio implicativo de natureza predominantemente inteligível (fase da moralização). Isso muda, todavia, quando o narrador, ao variar a perspectiva narrativa, traz à cena a interioridade da personagem, dando maior ênfase, ou em outras palavras, fazendo, agora, incidir o acento de sentido na sua pureza, ingenuidade e inocência. A interação entre Negrinha e o enunciatário-leitor, com essa mudança de ponto de vista, a partir do qual, por uma operação de triagem axiológica, sobressai o íntimo da pequena órfã, tonifica-se. A menina ganha densidade de presença e, mais do que a ação em si, o que passa a sensibilizar é justamente o efeito produzido pelas ações, pelo entorno, sobre a timia de Negrinha, agora apresentada de maneira evidente. Cria-se uma cumplicidade que permite o compartilhamento das emoções, o "sentir com" compassivo. O efeito passional, advindo de uma interação afetiva mais direta, imediata, torna-se, então, particularizante (valores de absoluto); não mais o sofrimento de uma criança, mas o de Negrinha.

A fronteira entre a afetividade que faz surgir os dois estados de alma analisados, compaixão e piedade, não é, portanto, estanque; o que explica o fato de eles serem muitas vezes considerados como afetos sinônimos. Trata-se de uma mesma cena passional, com a mesma distribuição dos papéis, das funções. A diferença reside naquilo que é privilegiado pelo sujeito da percepção, no modo de presença daquilo com que se estabelece a interação afetiva. 


\section{4 “Baleia”, de Graciliano Ramos: entre compaixão e piedade}

Criado como um texto autônomo, inicialmente publicado no jornal argentino La Prensa, o conto "Baleia”, de Graciliano Ramos, aparecerá pouco depois como um dos capítulos do livro Vidas Secas (1938). A carga tímica da estória, dentro desse "conjunto" que apresenta ao leitor, desde o início da obra e ao longo dos outros episódios, a cachorra e o que ela é e significa para toda a família, adquire ainda mais força de sensibilização. Mas mesmo se pensada individualmente, tal como faremos em nossa análise, a narrativa em questão mantém seu poder de convocação sensível e afetiva.

Atento ao sentir, ou, como gostava de dizer, "à alma" de suas personagens, o autor privilegia nesse conto a exploração do íntimo de Baleia, a sua resposta subjetiva à situação dramática vivida; e essa "transparência" permite ao enunciatário-leitor uma "visão" mais próxima dos acontecimentos, a partir do ponto de vista daquele que o vive. Conforme declara (RAMOS apud REIS, 1995, p. 72):

Acho que não é o tema que tem a maior importância. A miséria, por exemplo, pode não dar a quem a trata a mesma impressão que naquele que a sofre [...]. Objetivamente ela pode ter sido [tratada]. 0 objeto, a coisa, não está ali dentro do livro? Justamente o que desafinou foi a parte subjetiva. E sem ela não pode haver obra nenhuma, porque qualquer um só pode escrever o que sente e não o que os outros estão sentindo ou poderiam sentir.

Essa "ética" regente da estética de Graciliano Ramos reflete-se, portanto, no modo de interação afetiva que o leitor desenvolve com a estória narrada, com os atores do enunciado. Mesmo ao dar preferência à narração em terceira pessoa, o escritor, ao trabalhar engenhosamente as potencialidades dos discursos indireto e indireto livre, através do monólogo interior, faz a subjetividade suplantar as ações e ocupar o primeiro plano da estória. 0 enunciatário-leitor não apenas assimila objetivamente o conteúdo narrado, mas tem, então, a chance de o apreender também subjetivamente, a partir da interação afetiva com o ponto de vista da própria personagem. 
Construído com base em uma debreagem enunciva, o conto "Baleia”, ao "dar a ver" o cenário diegético e seus atores, concretiza-se sobretudo por imagens que privilegiam os estados mais do que as ações. Paira sobre toda a narrativa um imperioso silêncio, do qual emanam apenas alguns poucos resmungos, balbucios e, em primeiro plano, a voz interior dos atores do enunciado, o mais recôndito sentimento ou pensamento que trazem dentro de si. A narração alterna, pois, entre o ponto de vista externo, que caracteriza claramente a situação para o enunciatário-leitor, os estados de coisas, e o interno, que os subjetiviza, pondo em cena também os estados de alma.

No primeiro parágrafo do enunciado, o narrador, ao adotar a focalização externa, apresenta, de forma direta e incisiva, a circunstância-chave da estória, o estado de coisa central:

A cachorra Baleia estava para morrer. Tinha emagrecido, o pêlo caíra-lhe em vários pontos, as costelas avultavam num fundo róseo, onde manchas escuras supuravam e sangravam, cobertas de moscas. As chagas da boca e a inchação dos beiços dificultavamlhe a comida e a bebida. (RAMOS, 2009, p. 95)

A opção por uma frase afirmativa simples, direta e curta, com tom de constatação, para um conteúdo semântico tônico, logo na abertura do conto, impacta e já sensibiliza, principalmente porque a descrição detalhada subsequente, concentrada em uma isotopia figurativa do padecimento, da situação precária de Baleia, inicia a estória de maneira concessiva, com o quantum de morte sobressaindo ao de vida. Afetado pela emergência acelerada dos valores, o enunciatário-leitor se enternece, inferindo o sofrimento da cachorra e "sentindo por". Assim, embora o discurso em terceira pessoa o tenha "posicionado do lado fora" da narrativa, o que determinaria uma visão mais objetiva do conteúdo narrado, dado o efeito de assimetria entre o tempo-espaço do enunciado e o da enunciação pressuposta, a narração do estado de Baleia através de um ponto de vista eletivo convoca-o em sua sensibilidade.

O pesar configurado, produto da constatação da situação dramática da cachorra logo de início, tem, no entanto, caráter generalizante e comove não pela cumplicidade nas sensações, ou pelo vínculo direto com a personagem, mas pelo 
imaginar a dor a partir de um padecimento imerecido a qualquer ser vivo. A interação afetiva instaurada não chega a ser, desse modo, uma conjunção, por fusão, mas se configura como uma não-disjunção, da ordem da aproximação, sustentada sobretudo por valores de universo, procedentes da mistura axiológica entre os valores que marcam o entorno percebido e aqueles que se imagina investidos na personagem central.

Cria-se, de fato, um elo entre o enunciatário-leitor e Baleia, mas ele não é frontal, direto, e sim mediado por uma interpretação predominantemente inteligível. De toda forma, apiedado e sensibilizado ainda mais pela continuação das informações que reafirmam o suplício da cachorra e o incômodo provocado, a decisão de Fabiano - "Então Fabiano resolveu matá-la." (p. 95) -, mais uma vez expressa por uma sentença curta e incisiva, causa ao enunciatário-leitor desgosto e pesar, tal como para sinhá Vitória e os meninos: “- Vão bulir com a Baleia?” (p. 95); "Pobre da Baleia." (p. 96).

Instaura-se a partir daí uma espera expectante que faz a narração expandida pela descrição detalhada das ações de Fabiano, preparando-se para a execução, ser sentida como desacelerada no nível do enunciado, mas como recrudescente no nível da enunciação pressuposta, o que tonifica a aflição do enunciatário-leitor, e com ela o "sentir por", tal qual a angústia das personagens - "[Sinhá Vitória] Escutou, ouviu o rumor do chumbo que se derramava no cano da arma, as pancadas surdas da vareta na bucha. Suspirou. Coitadinha da Baleia." (p. 96). Fortalece-se a partir daí o vínculo entre o leitor e a cachorra e, com isso, o compadecimento generalizante cada vez mais se individualiza.

Em seguida entrou na sala, atravessou o corredor e chegou à janela baixa da cozinha. Examinou o terreiro, viu Baleia coçandose e a esfregar as peladuras no pé de turco, levou a espingarda ao rosto. A cachorra espiou o dono desconfiada, enroscou-se no tronco e foi-se desviando, até ficar no outro lado da árvore, agachada e arisca, mostrando apenas as pupilas negras. Aborrecido com esta manobra, Fabiano saltou a janela, esgueirouse ao longo da cerca do curral, deteve-se no mourão do canto e levou de novo a arma ao rosto. Como o animal estivesse de frente e não apresentasse bom alvo, adiantou-se mais alguns passos. Ao chegar às catingueiras, modificou a pontaria e puxou o gatilho. A carga alcançou os quartos de Baleia, que se pôs a latir 
desesperadamente.

[...] E Baleia fugiu precipitada, rodeou o barreiro, entrou no quintalzinho da esquerda, passou rente aos craveiros e às panelas de losna, meteu-se por um burco da cerca e ganhou o pátio, correndo em três pés. Dirigiu-se ao copiar, mas temeu encontrar Fabiano e afastou-se para o chiqueiro das cabras. Demorou-se aí por um instante, meio desorientada, saiu depois sem destino, aos pulos. (RAMOS, 2009, p. 96-97)

Aflito e embalado no suspense suscitado pela descrição sequencial da movimentação de Fabiano e temendo pela cachorra, o impacto do tiro é sentido também pelo enunciatário-leitor, que passa, então, a "sentir com" Baleia. A opção pela enumeração do comportamento, das ações da cachorra após o tiro, acelera o ritmo da narração e (re)cria na textualização do conteúdo, como efeito de sentido produzido, o seu desespero. A cachorra ganha densidade de presença e a atenção do enunciatário-leitor agora é toda voltada a ela. Estabelece-se uma cumplicidade que se solidifica na medida em que a narração tira o foco da situação, do estado de coisas, para concentrá-lo no sofrimento em si, no estado de alma.

A perspectiva da narrativa muda e passa a colocar em primeiro plano o padecimento de Baleia, ora caracterizado por um ponto de vista exterior e mais objetivo, da ordem do discurso indireto, no qual prevalece a apreensão do narrador, ora por um ponto de vista interno, mais subjetivo, da ordem do discurso indireto livre, com a percepção e a voz da personagem ressoando e prevalecendo na explanação dos entornos. Articulam-se, dessa forma, dois pontos de vista para a apresentação dos fatos: um dirigido pela inteligibilidade da instância narrativa e o outro pela subjetividade da cachorra. Isso tonifica a dedução do sofrimento, da dor sentida por ela. 0 leitor começa, então, a apreender a situação também a partir da interioridade, do íntimo da personagem, como acontece nesse trecho:

Esqueceu-os e de novo lhe veio o desejo de morder Fabiano, que lhe apareceu diante dos olhos meio vidrados, com um objeto esquisito na mão.

Não conhecia o objeto, mas pôs-se a tremer, convencida de que ele encerrava surpresas desagradáveis. Fez um esforço para desviarse daquilo e encolher o rabo. Cerrou as pálpebras pesadas e julgou que o rabo estava encolhido. Não poderia morder Fabiano: tinha nascido perto dele, numa camarinha, sob a cama de varas, e consumira a existência em submissão, ladrando para juntar o gado 
quando o vaqueiro batia palmas.

O objeto desconhecido continuavam a ameaçá-la. Conteve a respiração, cobriu os dentes, espiou o inimigo por baixo das pestanas caídas. Ficou assim algum tempo, depois sossegou. Fabiano e a coisa perigosa tinham-se sumido. (RAMOS, 2009, p. 98)

Se a narração desta cena mescla o discurso indireto e o indireto livre, fazendo sobressair em alguns momentos a "voz" e o ponto de vista do narrador e em outros a "voz" e o ponto de vista da personagem, a presença súbita de Fabiano é sentida pelo enunciatário-leitor da mesma maneira como para Baleia. Ao prever também o porvir disfórico, ele teme, encolhe-se e depois se tranquiliza com ela; e é exatamente essa sincronização estésica que garante a surpresa diante o comportamento concessivo da cachorra - "Não poderia morder Fabiano: tinha nascido perto dele, numa camarinha, sob a cama de varas, e consumira a existência em submissão, ladrando para juntar o gado quando o vaqueiro batia palmas." (p. 98). Tomado pela mesma tensão e medo que ela, o enunciatário-leitor se surpreende com a sua "solidariedade ética". A fidelidade demonstrada por Baleia, em detrimento ao instinto de sobrevivência que lhe seria próprio, humaniza-a e tonifica (mais mais) a interação afetiva estabelecida. 0 enunciatário compreende que, de fato, “[...] era um bicho diferente dos outros" (p. 97).

A emergência da subjetividade da cachorra cria, além disso, um paradoxo. De um lado, a personagem, ao assumir a "voz" enunciativa por uma embreagem enunciva ligada ao discurso indireto livre, ganha densidade de presença e humaniza-se aos olhos do leitor pela integridade da sua consciência e pela sua passionalidade; de outro, o conteúdo narrativo acompanha a progressiva perda da vida e a proximidade da morte: se vão os movimentos, logo depois os sentidos e com eles a consciência.

Baleia assustou-se. Que faziam aqueles animais soltos de noite? A obrigação dela era levantar-se, conduzi-los ao bebedouro. Franziu as ventas, procurando distinguir os meninos. Estranhou a ausência deles.

Não se lembrava de Fabiano. Tinha havido um desastre, mas Baleia não atribuía a esse desastre a importância em que se achava nem percebia que estava livre de responsabilidades. 
Uma angústia apertou-lhe o pequeno coração. Precisava vigiar as cabras: àquela hora cheiros de suçuarana deviam andar pelas ribanceiras, rondar as moitas afastadas. Felizmente os meninos dormiam na esteira, por baixo do caritó onde sinhá Vitória guardava o cachimbo. (RAMOS, 2009, p. 98)

Defronte do carro de bois faltou-lhe a perna traseira. E, perdendo muito sangue, andou como gente em dois pés, arrastando com dificuldade a parte posterior do corpo. [...] Caiu antes de alcançar essa cova arredada. Tentou erguer-se, endireitou as pernas dianteiras, mas o resto do corpo ficou deitado de banda. Nesta posição torcida, mexeu-se a custo, ralando as patas, cravando as unhas no chão, agarrando-se nos seixos miúdos. Afinal esmoreceu e aquietou-se junto às pedras onde os meninos jogavam cobras mortas. Uma sede horrível queimava-lhe a garganta. Procurou ver as pernas e não as distinguiu: um nevoeiro impedia-lhe a visão. Pôs-se a latir e desejou morder Fabiano. Realmente não latia: uivava baixinho, e os uivos iam diminuindo, tornavam-se quase imperceptíveis. [...]

Começou a arquejar penosamente, fingindo ladrar. Passou a língua pelos beiços, torrados e não experimentou nenhum prazer. $\underline{0}$ olfato cada vez mais se embotava: certamente os preás tinham fugido. [...]

Abriu os olhos a custo. Agora havia uma grande escuridão, com certeza o sol desaparecera. [...]

Uma noite de inverno, gelada e nevoenta, cercava a criaturinha. Silêncio completo, nenhum sinal de vida nos arredores. [...] Agora parecia que a fazenda tinha se despovoado.

Baleia respirava depressa, a boca aberta, os queixos desgovernados, a língua pendente e insensível. Não sabia o que tinha sucedido. 0 estrondo, a pancada que recebera no quarto e a viagem difícil no barreiro ao fim do pátio desvaneciam-se no seu espírito. [...]

A tremura subia, deixava a barriga e chegava ao peito de Baleia. Do outro peito para trás era tudo insensibilidade e esquecimento. Mas o resto do corpo se arrepiava, espinhos de mandacaru penetravam na carne meio comida pela doença.

Baleia encostava a cabecinha fatigada na pedra. A pedra estava fria, certamente sinhá Vitória tinha deixado o fogo apagar-se muito cedo.

Baleia queria dormir. Acordaria feliz, num mundo cheio de preás. (RAMOS, 2009, p. 97-99, grifo nosso)

Se o discurso indireto livre faz pulsar a vida, o ponto de vista externo, assumido pelo narrador, ocupa-se da concretização das circunstâncias que marcam a chegada da morte. Essa justaposição dos valores de vida e morte enfatiza a resistência e a obstinação de Baleia e, por conseguinte, recrudesce (mais mais) a interação afetiva do enunciatário-leitor, que agora se vê de fato conjunto à 
personagem, em uma interação plena, fusional. 0 uso do diminutivo em meio à narração final do padecimento vivido por Baleia - "encostava a cabecinha" mostra que mesmo o narrador é sensibilizado por esse momento, deixando transparecer certa comoção e afetividade.

Mas não é só o sofrimento da cachorra que comove, a lealdade à família de Fabiano também intensifica a simpatia, o elo afetivo direcionado a ela. Em todos os momentos, seja em meio às lembranças ou às alucinações, é aos meninos, a Fabiano e à Sinhá Vitória que o pensamento de Baleia se dirige - mesmo no instante final, quando o que ela quer é dormir e acordar feliz "num mundo cheio de preás" (p. 99). É com eles que ela quer desse novo mundo de fartura desfrutar - "E lamberia as mãos de Fabiano, um Fabiano enorme. As crianças se espojariam com ela, rolariam com ela num pátio enorme, num chiqueiro enorme. 0 mundo ficaria todo cheio de preás, gordos, enormes" (p. 99). 0 seu zelo e apego ao cumprimento dos deveres, em meio ao martírio vivido, quando já não conseguia nem mesmo ter consciência da própria situação, enfatizam a tensão subjacente e aumentam a força de sensibilização emocional do conteúdo. A interpretação inteligível do enunciatário-leitor fica, dessa forma, sensibilizada.

Conforme observa Marinho (2000, p. 86), “o discurso indireto livre não apenas mostra o mundo interior das personagens, mas o mostra em contraposição a uma exterioridade, representada pela visão do narrador". A narração descritiva do martírio e da agonia da cachorra, entrecruzada às manifestações de sua subjetividade, convoca a afetividade do enunciatário-leitor.

A alternância entre o ponto de vista exterior e interior, entre o acento de sentido na situação penosa de Baleia e no sofrimento experimentado por ela, faz com que os sentimentos de piedade e compaixão se alternem e se misturem. Nesse caso, o enunciatário-leitor "sente por" porque "sente com". O pesar não é mais fruto de uma sanção generalizante do conteúdo apreendido; é individualizado, resultado de uma triagem axiológica; ele é todo voltado à Baleia, como valores de absoluto. 


\subsubsection{Considerações sobre o resultado da análise}

Como a própria vizinhança semântica deixa entrever, e a análise comprovou, é mesmo fluida a fronteira que separa a piedade da compaixão, de modo que elas podem sim aparecer juntas, misturar-se. 0 que de fato importa, e as distingue, é, como mais uma vez ficou atestado, a fonte a partir da qual emanam os valores em jogo e, consequentemente, o direcionamento da atenção daquele que sente o afeto: esteja ela voltada ao acontecimento, ao entorno responsável pelo sofrimento, nesse caso inferido; ou ao padecimento em si, constatado, e, por isso mesmo, passível de estabelecer um compartilhamento direto, um crer-saber a dor do outro assumido e não apenas aderido.

No conto, o gerenciamento da percepção do enunciatário-leitor entre essas duas possibilidades é oscilante (fase da sensibilização); ora enfatiza, também de forma tônica, a situação, como acontece no início da narrativa; ora o martírio dela resultante, conforme a perspectiva adotada após o tiro. Em ambos os casos é restrita a profundidade do campo de presença (fase da disposição), de forma que nos dois modos de interação afetiva com o narrado a convocação sensível é grande (fase da patemização). 0 valor tímico (afetivo) dado ao valor axiológico em questão é, consequentemente, tônico (fase da moralização).

A ênfase no ponto de vista externo, no entanto, típico a uma observação mais objetiva da situação, faz com que a lástima suscitada, de natureza mais inteligível por ser o sofrimento deduzido a partir da descrição do acontecimento, do entorno, seja da ordem da generalização, de caráter mais social que individual. 0 ator do enunciado, nesse caso, representa um papel temático. Por outro lado, quando a prioridade passa a ser dada ao ponto de vista interno, ou interior, responsável pela "subjetivização" da perspectiva narrativa, colocando em relação direta o enunciatário-leitor e o padecimento vivido pela cachorra, o pesar desencadeado é resultado de uma sincronização sensível que patemiza e individualiza a interação, dando origem ao crer-saber-assumido.

Nas cenas da agonia de Baleia, a alternância entre essas duas estratégias de apresentação do conteúdo narrado, sendo constante e contígua, mantém alta a 
densidade passional do enunciado. Com isso, a interpretação generalizante do "sentir por" perde força e se especifica, em favor da personagem, do "sentir com". Mesclam-se também os sentimentos de compaixão e piedade, o que mostra a possibilidade de coexistência dos dois estados de alma; um não exclui ou invalida a presença do outro.

\subsection{Conclusão geral sobre as análises: avaliação das hipóteses teórico- metodológicas}

Com base nas etapas propostas em nossa interpretação tensiva do esquema passional canônico, procuramos examinar os procedimentos sintáxico-discursivos mobilizados nos enunciados, para a configuração dos efeitos patêmicos de compaixão e piedade, a partir dos quais se pôde apreender: (i) as particularidades de estruturação discursiva do campo de presença estabelecido entre o sujeito da percepção - o enunciatário-leitor - e o objeto-valor percebido - os atores do enunciado e o entorno que os caracteriza (fase da constituição); (ii) a predicação tensiva responsável pela dinâmica interna do espaço de interação afetiva (fase da sensibilização); e (iii) as condições de geração do modo de interação afetiva que rege a produção do "valor do valor", base do estado de alma desencadeado (fase da moralização).

A ideia era depreender as estratégias de orientação discursiva, que, ao determinarem as condições de intensidade e extensidade da atividade perceptiva (fase da disposição), respondem pelo modo de convocação sensível-inteligível do enunciatário-leitor (fase da patemização) na interação compassiva ou piedosa, pelo gerenciamento da sua resposta estésica (fase da emoção) e da assimilação inteligível (fase da moralização) da presença. Lembrando que "a intensidade em questão é aquela da força de assunção da enunciação, e a extensão é aquela da capacidade de desdobramento e de declinação figurativa da enunciação" (FONTANILLE, 2007, p. 258).

Queríamos verificar, ao conceber o processo de leitura como configuração passional em ato, se as condições discursivo-textuais depreendidas nas análises 
realizadas correspondiam à estrutura sintáxico-semântica elementar, definida hipoteticamente no capítulo anterior, dos sentimentos de compaixão e piedade. Nesse sentido, o estudo do corpus selecionado comprovou que os estados de alma, de maneira geral, englobam duas dinâmicas sintáxicas: uma de geração da carga patêmica, na qual atuam os modos primários de interação afetiva; e outra de investimento afetivo, responsável pelas circunstâncias de produção do "valor do valor", do modo complexo de interação afetiva.

Conforme demonstrado durante a realização das investigações, não é exatamente a estratégia de gerenciamento da intensidade e da extensidade do campo de presença - como levaria a pensar em um primeiro momento a análise de "Campo Geral" e "Conversa de bois", de Guimarães Rosa - o que diferencia a compaixão da piedade, mas sim aquilo que é colocado em perspectiva dentro desse campo tensivo. Tanto o exame de "Negrinha", de Monteiro Lobato, quanto do conto "Baleia”, de Graciliano Ramos, mostraram que mesmo a piedade pode advir de um campo de presença restrito e de forte intensidade, porque o que enfraquece, ou melhor, o que diminui o grau da interação afetiva desencadeada é, como havíamos sugerido no capítulo I, o modo como se institui no campo tensivo o objeto-valor do afeto: de maneira direta e exclusiva (triagem axiológica), ou indireta e difusa (mistura axiológica).

A diferença entre os estados de alma de compaixão e piedade reside, como se pôde confirmar, no nível de pertinência superior do processo de produção de uma interação e outra, no qual o modo de presença do objeto-valor do pesar suscitado é o que determina as especificidades do sentir compassivo ou piedoso. É por isso que compaixão e piedade podem ter as mesmas condições de instauração do campo tensivo, os mesmos modos primários de interação afetiva. 0 maior ou o menor grau de densidade de presença do objeto-valor do afeto é que, com efeito, define as especificidades (sensíveis / inteligíveis) de geração da paixão em causa.

Nos textos examinados em que predomina a interação afetiva por compaixão, a densidade de presença atuava, de fato, no auge de sua tonicidade perceptiva, dirigida por uma operação de triagem axiológica. 0 acento de sentido determinado pelas modulações tensivas, regentes e responsáveis pela dinamização 
do enunciado, do campo de coexistência do enunciatário-leitor e dos atores do enunciado, recaia, como pudemos constatar, diretamente na figura correspondente ao objeto-valor do pesar, fazendo com que a apreensão da presença, dos valores nela investidos, fosse conduzida por um andamento acelerado responsável, no processo de sensibilização, por um forte impacto sensível e uma subtração da possibilidade (durativa) de assimilação inteligível. A presença é sentida, pois, como um sobrevir, e na configuração do "valor do valor", do modo complexo de interação afetiva instaurado, domina a convocação sensível, que funde o sujeito da percepção ao objeto-valor da afetividade e faz com que a sanção intersubjetiva, da ordem dos valores de absoluto, determinante da natureza qualitativa do pesar configurado, seja de natureza dominantemente emocional. Daí o crer-saber-assumido, com a dor do outro sendo a própria dor.

$\mathrm{Na}$ interação afetiva por piedade, as análises corroboraram a hipótese de uma configuração diferente, na qual a densidade de presença se dá em um grau menor, operada por uma mistura axiológica própria à diluição do objeto-valor do afeto nos entornos. $\mathrm{O}$ acento de sentido resultante das modulações tensivas em jogo não se concentra na figura do objeto-valor da afetividade, mas se soma e se difunde sobre a figuratividade do entorno que o contextualiza no discurso. A relação interactancial é, portanto, indireta, mediada pelas circunstâncias que caracterizam a situação disfórica, o que desacelera o ritmo da apreensão dos valores em jogo e, por conseguinte, a força de impacto da presença, sentida como implicativa, como um pervir. Delineia-se um mínimo de duração à apreensão, suficiente ao processamento mais inteligível da presença, com o "valor do valor" procedendo de uma sensibilização na qual o inteligível ganha mais espaço e a partir da qual a alteridade interactancial, própria ao "sentir por", ao crer-saberaderido, é mantida. A sanção afetiva, dirigida por valores de universo, é, então, predominantemente de ordem moralizante.

Em suma, as operações de triagem e mistura axiológicas definem o estilo tensivo próprio ao estado de alma em causa. Intimamente relacionadas à percepção do sujeito, a seu modo de apreender os valores que emergem em seu campo perceptivo, é nelas que o figural e o figurativo se cruzam, que os níveis 
discursivo e tensivo se apoiam mutuamente, delineando as peculiaridades do sentir. Conduzidas pela concentração ou difusão da tonicidade perceptiva da presença, tais operações determinam o modo de interação afetiva, o estado de alma, de natureza mais sensível ou mais inteligível, que toma o sujeito da percepção.

Esse ponto de vista analítico, assentado em critérios bem diferentes daqueles propostos por Fontanille no verbete "Pitié", do Dictionnaire des passions littéraires, e em outras publicações sobre o mesmo tema (2003, 2005, 2006), mostrou-se realmente produtivo para compreender as particularidades sintáxicodiscursivas que diferenciam a compaixão da piedade, abrangendo traços da configuração que vão além das circunstâncias aspecto-temporais de realização da cena passional em questão. A partir dele, pudemos verificar, como demonstramos há pouco, quais as determinantes dos modos distintos de interagir, das peculiaridades do sentir em cada um desses estados de alma.

Ademais, essa forma de abordagem dos afetos, calcada no exame dos procedimentos de discursivização e textualização dos enunciados para compreender as condições de sua emergência, os efeitos de sentido passionais produzidos no discurso em ato, trouxe à cena a dimensão persuasiva dos núcleos patêmicos, chamando a atenção para a possibilidade de uma semiotização da retórica das paixões; tarefa esta que nos propomos a discutir no próximo capítulo.

Embora a retórica aristotélica tenha, desde a Antiguidade, chamado a atenção ao caráter manipulador das paixões, dedicando um estudo detalhado às particularidades de algumas delas, os apontamentos feitos por Aristóteles em sua Retórica - mesmo sublinhados pela advertência de que as "provas de persuasão", nas quais os afetos estão inseridos, devem ser todas fornecidas pelo discurso - são de caráter psíquico e social, relacionados, como era característico ao ponto de vista filosófico de sua época, a considerações e reflexões de ordem ética e moral, quase nada dizendo sobre as especificidades da configuração propriamente discursiva em cada $\operatorname{caso}^{79}$.

Assim, estabelecer um diálogo entre as duas disciplinas, a partir da

79 Uma discussão inicial sobre esse assunto foi apresentada no artigo "Semiótica e Retórica no estudo das paixões: diálogo entre a abordagem aristotélica e a perspectiva greimasiana", publicado em Semiótica: identidade e diálogos (PORTELA; BEIVIDAS; LOPES; SCHWARTZMANN, 2012). 
problemática da manipulação passional, parece produtivo e pode trazer a possibilidade de ampliar a perspectiva de análise das paixões em ambos os domínios: seja, como mencionamos há pouco, em um movimento de semiotização da retórica das paixões, ao tornar possível a depreensão e o estabelecimento das propriedades necessariamente discursivas das configurações passionais no discurso em ato, seja de retoricização da semiótica das paixões, assinalando a dimensão retórica dos núcleos patêmicos discursivizados. Em qualquer dos casos, importa avançar a ênfase dada à afetividade do sujeito do enunciado, ou ao discurso apaixonado do sujeito enunciante, e lançar luz tanto ao papel ocupado pelo enunciatário na produção da significação dos textos aos quais ele é exposto, quanto às condições discursivas de emergência da carga patêmica na relação intersubjetiva que ele estabelece com os atores do enunciado, ao processo de configuração do modo interação afetiva no momento do contato com o enunciado. 
Capítulo 4

Entre Retórica e Semiótica: uma semiotização da retórica das paixões 
Si l'objet de la sémiotique est une théorie discursive de la signification, il est clair que la prosodie et le discours sont de même échelle, ce qu'on ne saurait dire de la phonologie... Par voie de conséquence, la rhétorique cesse d'être une intruse et ce qui est à déterminer, c'est son rang dans une hiérarchie.

Claude Zilberberg

\subsection{Retórica e Semiótica: pontos de convergência}

A retórica - mesmo sendo o seu domínio os lugares de deliberação pública, como os tribunais e assembleias políticas - surge, na Antiguidade, como a primeira disciplina dedicada ao estudo técnico, ou melhor, teórico-metodológico do discurso, a "primeira reflexão sistemática sobre os poderes da linguagem" (KLINKENBERG, 2001, p. 11). Ao propor uma concepção racionalista da produção discursiva, na qual os efeitos de sentido produzidos e a força de influência operada através deles ocupam o primeiro plano, a retórica chama a atenção para a lógica interna do processo discursivo e oferece métodos (techné) próprios à "arte de bem falar" (apte e ornate), a uma actio eficiente sobre o auditório. Assim, embora muito se fale sobre o seu declínio e desprestígio, sobre a diversificação dos interesses e das formas de abordagem subsequentes, em geral, todas as teorias voltadas à análise dos discursos retomam, de uma maneira ou outra, algum apontamento, alguma noção operatória já assinalada pelos tratados retóricos que as precederam.

No caso específico da vizinhança entre a retórica e a semiótica do discurso, uma problemática central chama a atenção para o grande ponto de convergência entre as duas disciplinas - principalmente no que diz respeito aos desenvolvimentos contemporâneos desta última, cada vez mais voltados à problemática da enunciação, da práxis enunciativa e da semiose em ato: o interesse pelos processos de produção do sentido, estudados a partir do discurso, como objeto central de preocupação teórica, intimamente relacionados à interação entre o orador e o auditório (o enunciador e o enunciatário).

A primeira, a retórica, ocupa-se desses elementos, o discurso e os sujeitos 
envolvidos em sua produção-recepção, para pensar o poder de ação, de influência do enunciado proferido; ou seja, ela busca estabelecer quais as estratégias discursivas capazes de gerar a persuasão de maneira eficaz. A segunda, a semiótica do discurso, dirige sua atenção a eles para depreender, de modo semelhante, os processos de significação, de geração do sentido produzido a partir de certa prática significante, mesmo não tendo como foco a questão persuasiva.

Como se vê, embora existam diferenças epistemológicas entre as duas perspectivas, importa, para ambas, compreender as escolhas, os procedimentos discursivo-textuais subjacentes aos efeitos de sentido provocados, o que coloca em destaque não só a figura daquele que produz o discurso (o orador-enunciador), mas também a daquele a quem este último é dirigido (o auditório-enunciatário). Como bem esclarece Aristóteles, para citar um dentre os célebres nomes da retórica geral: "com efeito, um discurso comporta três elementos: a pessoa que fala, o assunto de que se fala e a pessoa a quem se fala; e o fim do discurso refere-se a esta última, que eu chamo o ouvinte" (s/d, p. 39).

Essa observação do filósofo grego traz à cena outro ponto de convergência entre as duas teorias, uma vez que tanto para a retórica quanto para a semiótica do discurso esses três elementos interessam analiticamente como simulacros, imagens suscitadas no e pelo enunciado que elas delimitam. Conforme destaca o estagirita, "entre as provas fornecidas pelo discurso, distinguem-se três espécies: umas residem no caráter moral do orador; outras nas disposições que se criam no ouvinte; outras, no próprio discurso, pelo que ele demonstra ou parece demonstrar" (s/d, p. 33, grifo nosso). Trata-se, portanto, nos dois casos, de três constituintes discursivos de fundamental importância por serem eles os pilares da estrutura comunicativa gerada.

Todavia, dentre esses elementos, ou melhor, essas "provas fornecidas pelo discurso", apenas duas foram realmente internalizadas e exploradas pela semiótica do discurso: (i) aquela que diz respeito à "pessoa que fala", o éthos, ou seja, a imagem do enunciador instituída a partir do enunciado produzido por ele; e (ii) a que se refere ao discurso em si, ao logos, aos procedimentos discursivos adotados pelo enunciador no momento da produção do seu enunciado. Mesmo tendo 
reconhecido a participação do "auditório", a que chama enunciatário, na produção da significação dos discursos, dada a sua influência direta sobre as escolhas e estratégias operadas, um estudo mais sistemático sobre a sua atuação - sobretudo no que o determina como pathos, ou melhor, como "disposição" a ser gerenciada, manipulada afetivamente - resta a fazer no domínio da semiótica de linha francesa; e é exatamente aí que, presumindo a viabilidade de um produtivo diálogo entre os desenvolvimentos atuais da teoria e aqueles fornecidos pela retórica geral, pretendemos, a partir de algumas ideias iniciais, poder propor algum avanço.

Nos estudos retóricos, nos quais a problemática da persuasão é central, o auditório ocupa papel de destaque, até porque é a ele que o discurso deve persuadir. Conforme assinala Mathieu-Castellani (2000, p. $19^{80}$ ) ao relembrar os ensinamentos da retórica: "o auditório é, portanto, o critério decisivo, pois é a ele que se reporta o fim, o foco (télos) da oratio". Mais do que apenas um receptor, o auditório é concebido em posição de "juiz", como aquele que sanciona o enunciado a ele aderindo ou se contrapondo. Daí a necessidade de poder influir em sua disposição, de poder levá-lo ao melhor ânimo, a um estado conveniente de receptividade. Como explica ainda a autora (Idem, p. $48^{81}$ ):

A palavra grega [pathos], para a qual o latim criaria vários equivalentes, entre os quais sobressaem os termos perturbatio, adfectus, ou motus animi, designa o estado de alma, sua disposição, em especial quando ela é despertada por alguma causa exterior; a qualidade de uma substância ou sua propriedade; mas também um acontecimento que se produz, uma mudança, uma alteração. [...] o pathos é considerado como uma qualidade alterável [...]; e, por fim, aquilo que experimentamos, que sofremos, e que produz no sujeito uma modificação.

É aí que as paixões, como modos de sensibilização, mostram a sua eficiência persuasiva, o seu papel na produção do julgamento que determina a forma de

80 Trecho original: "L'auditeur est ainsi le critère décisif, car c'est à lui que se rapporte la fin, la visée (télos) de l'oratio."

81 Trecho original: "Le mot grec [pathos], dont le latin donnera plusieurs équivalents, et notamment perturbatio, adfectus, ou motus animi, désigne l'état de l'âme, sa disposition, en particulier lorsqu'elle est agitée par quelque cause extérieure; la qualité d'une substance ou sa proprieté; mais aussi un événement qui se produit, un changement, une altération. [...] le pathos est défini comme une qualité altérable [...]; et enfin ce qu'on éprouve, ce qu'on subit, et qui produit dans le sujet une modification." 
adesão ao discurso; afinal, conforme salienta Aristóteles, “obtém-se a persuasão nos ouvintes, quando o discurso os leva a sentir uma paixão, porque os juízos que proferimos variam, consoante experimentamos aflição ou alegria, amizade ou ódio [...] é mesmo este o único fim a que visam os esforços" (s/d, p. 33), uma vez que, insiste ele, "os fatos não se revelam através do mesmo prisma, consoante se ama ou se odeia, se está irado ou em inteira calma. Mais. Os mesmos fatos tomam aparência inteiramente diferente e revestem outra importância" (s/d, p. 97); ele acrescenta ainda, “ora, as paixões são as causas que introduzem mudanças em nossos juízos [...]" (Idem, ibid).

A semiótica, por sua vez, ateve-se, em seus primórdios, aos limites do discurso enunciado, com a enunciação relegada ao estatuto de pressuposto lógico, e, assim, não dedicou grande atenção à noção de persuasão, que só foi abordada pelos semioticistas franceses a propósito do estudo da fase da manipulação do esquema narrativo canônico, e de qualquer maneira com características distintas daquelas do panorama retórico, isto é, como um fazer-fazer, um fazer-crer, e não necessariamente um fazer-sentir. Mesmo quando voltou a sua atenção à análise das paixões, da dimensão passional dos discursos, a teoria semiótica continuou a privilegiar o exame do enunciado manifestado, dos afetos já discursivizados, o que talvez explique o fato de, com a expansão dos estudos sobre a enunciação, a figura do enunciador ter sido claramente beneficiada em detrimento a do enunciatário. Há, entre os semioticistas greimasianos, quem fale da enunciação passional na perspectiva daquele que produz o discurso ${ }^{82}$, mas, até onde sabemos, muito pouco se tratou daquele a quem ele se dirige ${ }^{83}$.

Assim, depois de ter proposto uma atualização da semiótica das paixões na perspectiva do discurso em ato, na qual a problemática da enunciação e da tensividade é central, achamos possível retomar o diálogo entre retórica e semiótica para trazer à cena o enunciatário, o pathos do discurso, que não só toma conhecimento do conteúdo dos textos, mas se envolve e reage passionalmente a

82 Sobre esse assunto, consultar os trabalhos de Denis BERTRAND $(1986,2003)$ e Anne HÉNAULT (1986, 1994).

83 Há que mencionar, contudo, o artigo "O pathos do enunciatário", de José Luiz Fiorin, publicado na revista Alfa, número 48, volume 2, 2004, e republicado em seu livro Em busca do sentido: estudos discursivos, 2012; e o artigo "Ethos, pathos, et persuasion: le corps dans l'argumentation. Le cas du témoignage", de Jacques Fontanille, publicado na revista Semiotica, volume 163, 2007. 
ele, estabelecendo, para além da assimilação cognitiva, uma interação afetiva. A ideia é compreender de que modo, tal como no ponto de vista da retórica, ligam-se as instâncias do enunciador, do enunciado e do enunciatário na produção dos efeitos passionais, no gerenciamento do envolvimento patêmico deste último; como, a partir das estratégias de produção dos textos, pode-se influir na configuração do "julgamento", da sanção intersubjetiva que determina o modo de adesão ao conteúdo enunciado, o modo de assunção enunciativa por parte do enunciatário.

Como destaca Bertrand (2007, p. $75^{84}$ ):

Aparentemente reservada à retórica restrita da elocutio, que dela se apoderou, associando intimamente a estesia à produção dos efeitos estéticos nas figuras do discurso, a questão da sensibilização emocional encontra-se, na verdade, desde Aristóteles, no cerne da retórica geral. Objeto precípuo do Livro II do célebre tratado, ela é ali concebida como princípio operatório da eficácia de um discurso que, buscando influenciar, tende ao mesmo tempo a modificar os estados de alma do auditório.

Desse modo, ao estabelecer um diálogo com a perspectiva retórica, a competência discursiva, à qual está atrelada a manipulação, a atividade persuasiva, será pensada não apenas como um fazer-fazer, mas, antes de mais nada, no nível da enunciação, como um saber-fazer-sentir que regula o fazer-crer, com o sensível articulado ao inteligível no momento de configuração da sanção epistêmica. Acreditamos que esse ponto de vista seja válido por abrir caminhos, para a semiótica do discurso, a um estudo teórico-metodológico não só a propósito da problemática da persuasão, mas também da experiência estética.

\subsection{A articulação do sensível com o inteligível no momento da sanção: quando o fazer-crer é também um fazer-sentir}

Embora a semiótica greimasiana - por ter optado inicialmente pelo exame

84 Trecho original: “Apparemment réservée à la rhétorique restreinte de l'elocutio, qui se l'est pour ainsi dire appropriée associant étroitement l'esthésie à la production des effets esthétiques dans les figures du discours, la question de la sensibilisation émotionnelle se trouve en réalité au coeur de la rhétorique générale depuis Aristote. Objet même du Livre II du célèbre traité, elle y est assumée comme principe opératoire de l'efficacité d'une parole qui, cherchant à influencer, tend du même coup à modifier les états d'âme de son auditoire." 
do discurso enunciado - não tenha dedicado grande atenção à questão da persuasão, ela sempre admitiu a sua presença. Via-a, no entanto, na perspectiva da narratividade, como um fazer cognitivo simplesmente, um fazer-crer sem qualquer relação com o patêmico, com as paixões que se devem instilar no ânimo do sujeito para melhor controlar a configuração do seu "julgamento", da sua sanção. É bem verdade que, na época de tais formulações, com o interesse dirigido quase que exclusivamente ao nível narrativo dos discursos, o passional, ou, mais do que isso, a articulação do sensível com o inteligível não era ainda alvo do interesse dos semioticistas.

A sanção ficou definida, então, no quadro geral da teoria, como "uma figura discursiva correlata à manipulação, a qual, uma vez inscrita no esquema narrativo, se localiza nas duas dimensões, na pragmática e na cognitiva" (GREIMAS; COURTÉS, 2008, p. 426). Concebendo-a como juízo epistêmico, seja no nível do enunciado, seja no da enunciação, os autores do Dicionário de semiótica, no verbete “Epistêmicas (Modalidades )", explicam (Idem, p. 172-173, grifo nosso):

As modalidades epistêmicas dizem respeito à competência do enunciatário (ou, no caso do discurso narrativo, do Destinador final) que, em seguida ao seu fazer interpretativo, "toma a cargo", assume (ou sanciona) as posições cognitivas formuladas pelo enunciador (ou submetidas pelo Sujeito). Na medida em que no interior do contrato enunciativo (implícito ou explícito) o enunciador exerce um fazer persuasivo (isto é, fazer-crer), $o$ enunciatário, por sua vez, finaliza o seu fazer interpretativo por um juízo epistêmico (isto é, por um crer) que ele emite sobre os enunciados de estado que lhe são submetidos. [...] a categoria epistêmica comporta apenas oposições graduais e relativas que permitem a manifestação de um grande número de posições intermediárias. Esse estatuto particular das modalidades epistêmicas abre simplesmente uma nova problemática, a da competência epistêmica: o juízo epistêmico não depende somente do valor do fazer interpretativo que se supõe o preceda (isto é, do saber que incide sobre as modalizações veridictórias do enunciado), mas também - numa medida a ser ainda determinada - do querercrer e do poder-crer do sujeito epistêmico.

A nosso ver, é exatamente aí, na ideia de "competência epistêmica", que reside o lugar de atuação do passional; afinal, como salientam os semioticistas citados: "o juízo epistêmico não depende somente do valor do fazer interpretativo 
que se supõe o preceda (isto é, do saber que incide sobre as modalizações veridictórias do enunciado), mas também - numa medida a ser ainda determinada - do querer-crer e do poder-crer do sujeito epistêmico" (Idem, p. 173). Mesmo sabendo que a noção de competência epistêmica é concebida aí em função do percurso narrativo do sujeito, acreditamos que, se pensada no nível da enunciação, do discurso em ato, ela pode remeter à atuação do enunciador no gerenciamento do modo de assunção enunciativa do enunciatário, da sua resposta tímica, afetiva, ao que lhe é exposto, "às posições cognitivas formuladas" (Idem, p. 173); ela diz respeito, portanto, ao modo como o conteúdo do discurso é apresentado.

Conforme explica Fontanille (2002b, p. $78^{85}$ ), “a assunção enunciativa é uma propriedade do discurso, que diz respeito ao envolvimento do sujeito da enunciação [enunciador e enunciatário] em seu enunciado, e aos valores que este último comunica". As modulações interpostas à "maneira de dizer" do enunciador, de apresentar ao enunciatário o conteúdo, mostram aí a sua eficácia persuasiva, aliando ao fazer-crer um fazer-sentir que o precede e determina.

Para Mathieu-Castellani (2000, p. 97 ${ }^{86}$ ), "trata-se, precisamente, para o orador, de impor às 'coisas' uma imagem, uma representação que as fará ser avaliadas da maneira como ele deseja". Ela explica (Idem, $i b i d^{87}$ ):

0 prazer [e o desprazer] que pode suscitar o discurso não tem nada de gratuito; ele é a resultante do exercício de manipulação: na perspectiva pragmática da retórica latina, o orador deve se perguntar como provocar as paixões, ciente de que o homem obedece a seus impulsos irracionais e a seus sentidos mais do que à razão, e que o exercício do judicium, o judicare, está estritamente relacionado à emoção e ao desejo que ele é capaz de suscitar no auditório. Ora, como sustenta Cícero [...] a origem da paixão é a opinio, a espera, a representação, poderíamos dizer, que se forma

85 Trecho original: "La asunción enunciativa es una propiedad del discurso que atañe al compromiso del sujeto de la enunciación con su enunciado y a los valores que este último comunica; [...]"

86 Trecho original: "Pour l'orateur, il s'agira précisément de modifier les opinions, d'imposer des 'choses' une image, une représentation qui les fera apprécier de la façon qu'il souhaite."

87 Trecho original: "Le plaisir que peut donner la parole n'a rien de gratuit; il est le nécessaire préliminaire à l'exercice d'influence: dans la perspective pragmatique de la rhétorique latine, l'orateur doit se demander comment émouvoir les passions, sachant bien que l'homme obéit à ses impulsions irrationnelles et à ses sens plus qu'à la raison, et que l'exercice du judicium, le judicare, est sous l'étroite dépendance de l'émotion et du désir qu'il saura susciter dans l'auditoire. [...] l'origine de la passion est l'opinio l'attente, on pourrait dire la représentation qui se forme dans l'esprit, ce qu'Aristote nommait la phantasia [...]" 
na mente, a qual Aristóteles denominava phantasia $[\ldots]$

Embora a perspectiva da autora citada, assentada na clássica oposição entre o sensível e o inteligível, as paixões e a razão, seja diferente da nossa, sua colocação interessa por chamar a atenção para a força do discurso na sensibilização da sanção do auditório, para o poder do discurso - logo, do seu enunciador-orador na determinação da recategorização axiológica dos valores postos em cena, colocando as paixões despertadas como resultado da interação tímico-fórica estabelecida com o conteúdo do discurso, como resposta aos efeitos de sentido produzidos, à predicação tensiva da categoria semântica de base.

Mantendo essa linha que privilegia a recepção, ou melhor, a interpretação judicativa atrelada à produção do discurso, podemos dizer que o início do processo de sensibilização emocional operado pelo enunciador-orador está, nesse sentido, intimamente relacionado à escolha da direção argumentativa, isto é, à tomada de posição perante a oposição elementar que edifica o texto. Assim, ao imprimir, a partir desse posicionamento axiológico, uma orientação discursiva ao enunciado, e a sua recepção, o enunciador estaria apto a incutir, no processo de discursivização e textualização, uma espécie de carga de sentido suplementar, uma tensão que transforma o discurso em um campo de existência modulado, no qual o modo de apreensão do que é dito - e, sobretudo, dos valores que o sustentam -, de assunção enunciativa por parte do enunciatário-auditório, fica condicionado à dinâmica tensiva instaurada, às modulações procedentes da maneira de dizer, de apresentar a categoria de base. Como confirmam as palavras de Aristóteles (s/d, p. 41):

[...] quando se louva ou se censura, quando se aconselha ou se desaconselha, quando se acusa ou se defende, ninguém se empenha só em demonstrar o que afirmou; mas todos se propõem, além disso, a mostrar a importância, grande ou pequena do bem e do mal, do belo e do feio, do justo e do injusto, que o assunto encerra, quer estes pontos sejam tratados em si separadamente, quer sejam mutuamente postos em confronto e oposição.

Os valores semânticos colocados em situação pela atividade de produção convertem-se, no momento da recepção, do contato com o texto, em valores 
tímicos, axiologizados. É, por conseguinte, o tratamento tensivo dado à categoria semântica de base no momento da colocação em discurso que - consoante os dados depreendidos a partir das análises realizadas no capítulo anterior responde por essa modificação (tal como entendida na noção aristotélica de pathos). Essa seria a maneira de, na perspectiva mais geral da práxis enunciativa, agir sobre a configuração da competência epistêmica do enunciatário, com o sensível, o patêmico, influindo diretamente sobre o inteligível, sobre a sanção.

Ao gerenciar o grau de presença de cada um dos termos que compõem a oposição elementar do discurso no processo sintagmático, o enunciador regula o modo de convocação tímico-fórica do enunciatário, o seu modo de assunção enunciativa: mais sensível ou mais inteligível, conforme melhor lhe convenha. Segundo ressalta Mathieu-Castellani (2000, p. 54 ${ }^{88}$ ), a partir dos ensinamentos de Cícero, em De Oratore, “o juiz, dominus rei, senhor da situação [...], deve, por sua vez, ser dominado pelo orador, ad causam oratione moderandus, isto é, levado da benevolência ao ódio, do ódio à benevolência, governado por suas paixões ao sabor do discurso que as excita."

Insere-se aí, então, a problemática dos modos de existência, do controle dos graus de presença das grandezas discursivas em oposição, com o figural atuando sobre o figurativo na produção dos efeitos de sentido passionais. Se este último, o figurativo, concretiza as evidências, os argumentos - e a partir deles a argumentação em si -, conduzindo o enunciatário-auditório a crer na posição axiológica assumida pelo enunciador-orador, o primeiro, o figural, caracteriza o modo de acesso a essas provas argumentativas e leva-o, antes de tudo, a sentir.

O julgamento epistêmico, próprio à configuração do "valor do valor" subjacente à paixão desencadeada, procede, pois, não só de um esforço cognitivo de interpretação, mas de uma sensibilização emocional prévia (tônica ou átona) operada ao longo do processo de apreensão do conteúdo pela manipulação dos valores em discurso, da tensão que os faz interagir. Para Bertrand (2007, p. 80 ${ }^{89}$ ),

88 Trecho original: “[...] le juge dominus rei, maître de la situation [...], doit être à son tour dominé par l'orateur, ad causam oratione moderandus, c'est-à-dire incliné de la bienveillance à la haine, de la haine à la bienveillance, gouverné par ses passions au gré de la parole qui les excite."

89 Trecho original: "Par les variations de ces degrés, un sens labile se déploie en se dissimulant ou en se manifestant, en se suggérant ou en s'exaltant. [...] La charge thymique trouve ici son lieu d'exercice final, comme un événement de reconnaissance." 
"pelas variações dos graus [de presença], cria-se um sentido lábil que ora se dissimula, ora se manifesta, ora se sugere, ora se exalta. [...] A carga tímica encontra aí o seu lugar final de exercício, como um acontecimento de reconhecimento."

Os efeitos de sentido sensíveis produzidos no e pelo discurso provêm, dessa forma, não exatamente da figuratividade, mas, como vimos nas análises do capítulo anterior, da tensão que sobredetermina a categoria semântica de base subjacente ao enunciado, prescrevendo ao mesmo tempo o modo de inserção, e de assimilação dos valores investidos no componente figurativo - domínio no qual atua, por sua vez, o figural. A problemática da tensividade, da análise tensiva, mostra aí a sua produtividade para o estabelecimento do diálogo, a partir do ponto de vista da sensibilização emocional em ato, entre retórica e semiótica. Conforme bem lembram Bordron e Fontanille (2000, p. 10-11 ${ }^{90}$ ):

Introduzir em uma categoria, ou em um campo discursivo, uma tensão semântica, ou até mesmo direções argumentativas opostas, é suscitar aí [...] o surgimento de valores; é instituir no seio dessa categoria ou desse campo discursivo orientações concorrentes, diferenças, em suma, um esboço de sistema de valores. Isso significa que a dimensão retórica do discurso seria parte integrante da formação dos sistemas de valores, na perspectiva do discurso em ato; [...]

A axiologização da oposição elementar que sustenta o discurso, ao definir a interação entre as duas grandezas como uma relação orientada, dirigida por uma intencionalidade, mostra-se, assim, como elemento-chave da dimensão retórica do discurso, passível, por isso mesmo, de ser concebida como uma dimensão polêmica, uma dimensão tensiva. Para que se possa tirar proveito do potencial persuasivo dessa categoria, a confrontação dos dois universos semânticos de base - vida vs. morte, por exemplo -, bem como sua manifestação discursiva, devem ser reguladas pelo enunciador-orador, que, consequentemente, passa a ter maior domínio sobre os efeitos de sentido sensíveis a partir daí produzidos. É o que

90 Trecho original: "Introduire dans une catégorie ou un champ discursif une tension sémantique, voire des directions argumentatives opposées, c'est y susciter [...] l'apparition de valeurs; c'est disposer au sein de cette catégorie ou de ce champ discursif des orientations concurrentes, des différences, donc l'ébauche d'un système de valeurs. Cela signifie que la dimension rhétorique du discours participerait de la formation des systèmes de valeurs, dans la perspective du discours en acte; $[\ldots . .]^{\prime \prime}$ 
acontece no conto "Baleia", de Graciliano Ramos, quando o enunciador, logo no início do conto, para sensibilizar a apreensão dos valores em questão, tonifica, com a ajuda da isotopia figurativa manifestada, o quantum do valor de morte na sua relação de intensidade com o valor de vida.

A dimensão retórica do discurso foi, de fato, definida pelos semioticistas franceses, a título de hipótese, no momento em que se dedicaram ao possível diálogo entre semiótica e retórica ${ }^{91}$, como espaço de coexistência de duas grandezas semânticas postas em conflito, em competição. Embora essa acepção tenha sido estabelecida em função das figuras retóricas, os tropos, acreditamos que, por englobar a dimensão tímico-fórica dos enunciados, ela abrange também, sem nenhum inconveniente, conforme tentamos demonstrar até aqui, a atividade argumentativa na qual se insere a problemática das paixões, ou melhor, da sensibilização exercida pelo enunciador-orador, por meio do discurso produzido, sobre o enunciatário-auditório; tal qual confirmam os dois autores mencionados há pouco (BORDRON; FONTANILLE, 2000, p. $7^{92}$ ) ao esclarecer que "a dimensão retórica reagruparia, na perspectiva do discurso em ato, o conjunto de procedimentos capazes de gerenciar a coexistência problemática entre duas grandezas em competição".

Desse modo, cientes de que é próprio à retórica organizar, determinar e fixar operações da práxis enunciativa eficientes à atividade persuasiva, aproveitaremos a discussão teórico-metodológica apresentada por Bordron e Fontanille no texto já citado, bem como em outras publicações de Fontanille (1999; 2002b) sobre o mesmo assunto, para semiotizar, desta vez, não a retórica dos tropos, mas a das paixões, buscando demonstrar a quais operações sintáxicodiscursivas o enunciador-orador pode recorrer para sensibilizar, da maneira como deseja, o seu enunciatário-auditório. A intenção é a de interpretar o esquema retórico canônico, proposto por Fontanille (2002b), na perspectiva do passional, da

91 Em 1998, o Séminaire Intersémiotique de Paris dedicou-se ao confronto entre a perspectiva retórica e a semiótica, buscando depreender o possível diálogo entre as duas disciplinas. Dois anos mais tarde, surgia o número 137 da revista Langages, dirigido por Jean-François Bordron e Jacques Fontanille, intitulado "Sémiotique du discours et tensions rhétoriques".

92 Trecho original: "[...] la dimension rhétorique regrouperait, dans la perspective du discours en acte, l'ensemble des procédures permettant de gérer la co-habitation problématique entre deux grandeurs en compétition." 
sensibilização emocional que patemiza o discurso e, por conseguinte, também a sua apreensão, submetendo a interpretação judicativa ao sentir, à experiência sensível a ela imposta.

\subsection{0 gerenciamento do pathos do enunciatário no discurso do enunciador- orador}

Considerando tanto a produção do enunciado quanto a sua interpretação como atos de semiose, acreditamos que o percurso de sensibilização do enuciatário-auditório no discurso em ato é suscetível de ser formalizado aspectualmente ${ }^{93}$, a partir de três momentos: (i) o incoativo, que diria respeito às condições de emergência da significação, ao instante em que se inicia o contato com o discurso; (ii) o durativo, próprio ao processo de configuração da significação, de sensibilização da assimilação do conteúdo; e (iii) o terminativo, quando o enunciatário-auditório, tendo apreendido a totalidade discursivo-textual a partir da qual se concatena a sua competência epistêmica, sanciona o enunciado a ele aderindo ou se contrapondo ${ }^{94}$.

A atuação da atividade persuasiva se incutiria nas duas primeiras fases desse percurso de interação, a incoativa e a durativa, responsáveis pela determinação do modo de inserção, e consequentemente, de apreensão, dos valores. Afinal, como atesta Mathieu-Castellani (2000, p. $4^{95}$ ), "a recepção emotiva da mensagem está condicionada pelas modalidades de sua transmissão". Assim, enquanto a primeira etapa concerne à maneira de articular a categoria semântica de base, tirando da tensão a ela imanente o maior proveito, a segunda concerne à regulação do diálogo entre a convocação sensível e inteligível ao longo do desenvolvimento do discurso.

De acordo com Bordron e Fontanille (2000, p. $14^{96}$ ):

93 Adaptação da proposta formulada por Fontanille em seu livro Sémiotique et littérature (1999), a propósito do discurso em ato (p. 8).

94 Sobre a aspectualização da atividade enunciativa na perspectiva do enunciador, pensada como fundamentação do estilo, consultar a tese de livre docência defendida por Discini (2013).

95 Trecho original: "[...] la réception émotive du message est aussi conditionnée par les modalités de sa transmission; [...]"

96 Trecho original: "En effet, la dimension rhétorique de nos pratiques sémiotiques a quelque chose 
De fato, a dimensão retórica de nossas práticas semióticas está, de alguma forma, [...] relacionada a tudo aquilo que constitui o cerne da semiose: a tomada de posição (constitutiva do campo do discurso para a semiótica estrutural ou pós-estrutural, constitutiva do ground para a semiótica peirciana); a formação de sistemas de valores (constitutiva de diferenças significantes); a distinção entre os modos de existência (constitutiva de uma espécie de "profundidade" do discurso); etc.

Sem desconsiderar o modelo de análise proposto pela retórica antiga, que concebia a composição discursiva em cinco partes: inventio, dispositio, elocutio, memoria e actio / pronuntiatio, mas o integrando a uma concepção mais geral da produção dos discursos, acreditamos que as estratégias enunciativas, enquanto operações retóricas de manipulação dos valores, próprias ao esquema predicativo operado pelo enunciador-orador, que tem a seu encargo o gerenciamento do pathos do enunciatário-auditório, podem, para facilitar o seu exame, ser firmadas com base nas etapas do esquema retórico canônico sugerido por Fontanille em seu artigo "Retórica y manipulación de los valores" - publicado em 2002b, pela revista Tópicos del Seminario, número 8 -, com o qual ele viabiliza uma forma de análise semiótica das figuras retóricas, os tropos, buscando "compreender como as operações retóricas produzem os efeitos axiológicos que afetam as categorias discursivas" (p. $75^{97}$ ).

A dimensão retórica do discurso é constituída, segundo o autor, por um pequeno número de categorias discursivas: a intensidade, a quantidade, o conflito e a assunção, "consideradas como categorias da práxis enunciativa ela mesma" (FONTANILLE, 2002b, p. $76^{98}$ ); e são exatamente elas que nos levam a acreditar na viabilidade da homologação entre as duas perspectivas de abordagem da atividade persuasiva - a do processo de sensibilização emocional, de gerenciamento do pathos do enunciatário-auditório, e a das figuras retóricas -, uma vez que,

à voir, [...] avec tout ce qui constitue le cœur de la semiosis: la prise de position (constitutive du champ du discours pour la sémiotique structurale ou post-structurale, constitutive du ground pour la sémiotique peircienne); la formation des systèmes de valeur (constitutive des différences signifiantes); la distinction entre les modes d'existence (constitutive d'une sorte de 'profondeur' du discours); etc."

97 Trecho original: "[...] comprender cómo las operaciones retóricas producen efectos axiológicos que afectan las categorías discursivas."

98 Trecho original: "[...] consideradas como las categorías de la própria praxis enunciativa." 
atualizadas no discurso, essas categorias respondem, de maneira geral, pelas condições de produção-recepção do texto, pela atividade discursiva, e persuasiva, como um todo, na qual enunciador, enunciado e enunciatário (éthos, logos e pathos) se inter-relacionam. Ainda nas palavras de Fontanille (2002b, p. $84^{99}$ ):

A solidariedade observada entre as categorias da práxis enunciativa [...] convida a associá-las a um princípio comum, de cunho sintáxico, que seria a forma de toda operação na dimensão retórica do discurso: essa forma se apresenta como uma sequência canônica, a qual, de certo modo, assume a "intencionalidade" operativa das transformações retóricas.

O esquema retórico canônico proposto pelo semioticista citado opera, conforme ele explica no artigo, sob duas perspectivas, as quais ele nomeia: ponto de vista pragmático (aquele da geração sintáxica da figura); e ponto de vista cognitivo (aquele de sua interpretação). Para cada um, ele atribui as seguintes fases:

\begin{tabular}{|c|c|}
\hline P.d.v. pragmático (geração) & P.d.v. cognitivo (interpretação) \\
\hline CONFRONTAÇÃOO & PROBLEMATIZAÇÃO \\
\hline DOMINAÇÃO-MEDIAÇÃO & CONTROLE-ASSUNÇÃO \\
\hline RESOLUÇÃO & MODO INTERPRETATIVO \\
\hline
\end{tabular}

Tabela 4.1: Tabela das fases dos dois pontos de vista que sustentam o esquema retórico canônico (conforme apresentada no referido artigo - Idem, p. 85-86).

Com a mesma denominação das fases, mas adaptando um pouco a sua concepção inicial, idealizada em função das figuras retóricas, propomos, ao pensar na formalização sintáxica do processo de sensibilização emocional mais geral, isto é, relacionado ao exercício argumentativo em seu conjunto, falar em ponto de vista da produção (a encargo do enunciador) e ponto de vista da recepção (da parte do enunciatário) - produção e recepção intrinsecamente relacionadas, com o

99 Trecho original: "La solidaridad que hemos observado entre las categorías de la práxis enunciativa [...] invita a llevarlas a un fondo comúm, de tipo sintáctico, y que sería la forma de toda operación em la dimensión retórica del discurso: esta forma toma la apariencia de una secuencia canónica, que, de alguma manera, se encarga de la 'intencionalidad' operativa de las transformaciones retóricas." 
desenvolvimento da primeira diretamente atrelado ao percurso interpretativo próprio à segunda.

Ademais, para manter a representação clássica dos esquemas canônicos, concebidos como etapas que sucedem uma a outra a partir de uma relação de pressuposição lógica, optaremos pela seguinte forma de esquematização (Cf. Esquema 4.1):

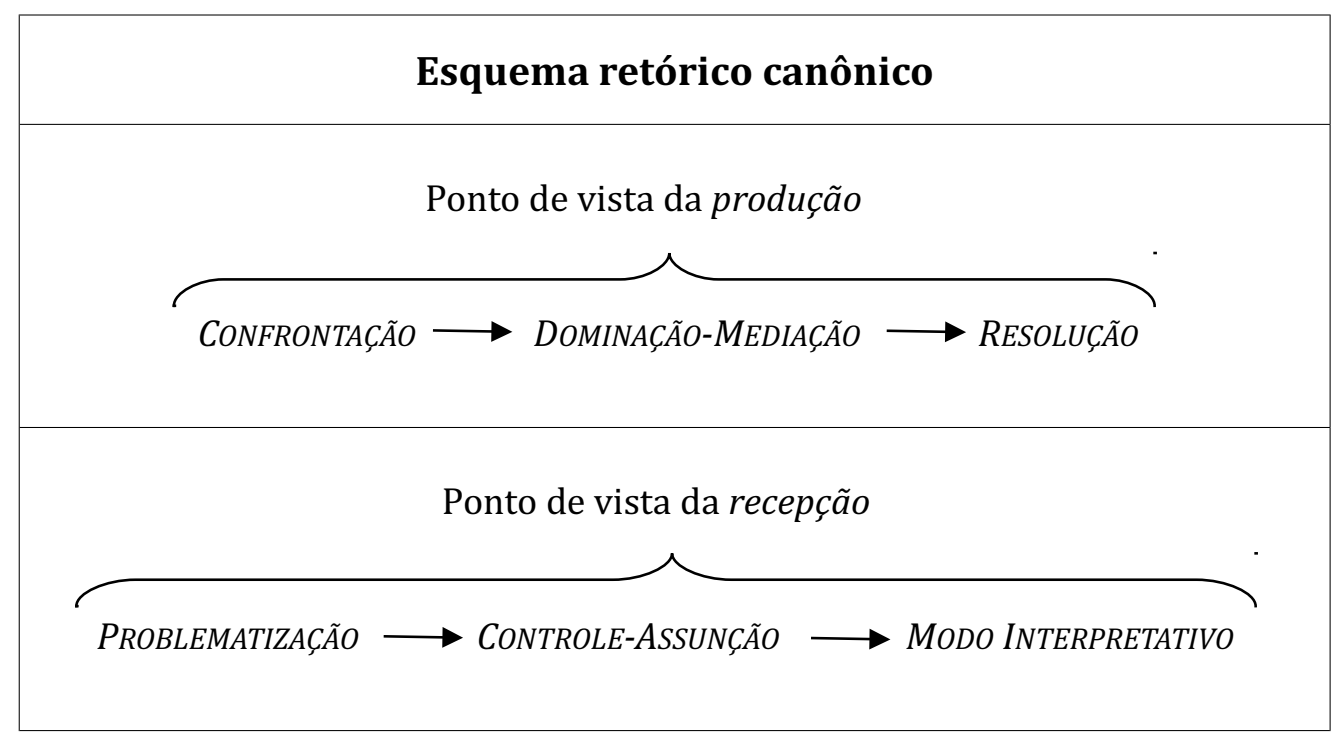

Esquema 4.1: Esquemas das fases dos dois pontos de vista possíveis para o esquema retórico canônico (elaboração nossa a partir da tabela proposta no referido artigo - FONTANILLE, 2002).

Nesse espírito, a fase da confrontação / problematização será por nós entendida como aquela da tomada de posição perante a oposição elementar subjacente à configuração discursiva, com um dos polos determinado como eufórico e outro como disfórico. Se o enunciador-orador demarca essa valorização axiológica na produção de seu enunciado, confrontando duas linhas argumentativas a partir das quais uma será a defendida, o enunciatário-auditório, de sua parte, identifica o conflito, a problematização, entre elas na expectativa do desenvolvimento argumentativo.

É aí que atua a fase da dominação-mediação / controle-assunção - etapa retórica por excelência -, com o enunciador-orador regulando os graus de presença dos dois universos semânticos e, por conseguinte, a tensão estabelecida entre eles, 
a sua força de impacto e de convocação da interação sensível-inteligível do enunciatário-auditório com o conteúdo que se desenvolve. Trata-se da fase de controle da interpretação, da sanção, do modo de assunção enunciativa (forte ou fraca, direta ou indireta - tal como foi sugerido na discussão sobre os modos de interação afetiva, apresentada no capítulo I) da instância de recepção do discurso.

Tendo o domínio da tensão que patemiza o enunciado, o enunciador-orador enfatiza como quer o posicionamento assumido por ele, seja em um estilo ascendente, que tonifica o conflito semântico, dando maior força de impacto, de convocação sensível, à linha argumentativa defendida, seja em um estilo descendente, que o atoniza, com maior apelo à assimilação inteligível do enunciatário-auditório - conforme as proposições de Zilberberg (2011) ao falar dos estilos tensivos. $\mathrm{Na}$ primeira possibilidade de predicação tensiva, o enunciador-orador adota uma estratégia argumentativa de intensificação da sensibilização emocional da sanção, com o sensível dominando o inteligível; na segunda, de enfraquecimento, "chamando à razão" o seu enunciatário-auditório, isto é, diminuindo a influência do sensível sobre o inteligível. Segundo corroboram Bordron e Fontanille (2000, p. $10^{100}$ ), “a carga tímica está intimamente relacionada com os potenciais semânticos de intensidade das figuras".

Esse ponto de vista vai ao encontro da observação de Mathieu-Castellani (2000) ao se referir à perspectiva retórica de análise das paixões: "o modelo de descrição que se impõe é o de um mecanismo em bom funcionamento, de uma máquina funcionando pelo princípio de ação e reação, capaz de provocar um movimento (ducere), e depois revertê-lo ao estado anterior (deducere), de levar para cá e para lá o auditório" (p. $72^{101}$ ). Ela acrescenta ainda: “o bom orador é aquele que suscita em seu auditório toda gama de paixões contrárias, assegurando assim a eficácia de seu discurso e seu poder sobre o auditório; trata-se de uma operação de domínio" (p. $77^{102}$ ).

100 Trecho original: "[...] la charge thymique est en relation étroite avec les potentiels sémantiques d'intensité des figures."

101 Trecho original: "Le modèle de description qui s'impose est celui d'une mécanique bien réglée, d'une machine fonctionnant sur le principe de l'action et de la réaction, capable de provoquer un mouvement (ducere), puis de faire revenir à un état antérieur (deducere), de mener çà e là l'auditeur."

102 Trecho original: “[...] le bon orateur est celui qui fait parcourir à son auditoire toute la gamme des passions contraires, et s'assure ainsi de l'efficacité de sa parole, en constant son pouvoir sur 
A atividade discursiva, ou melhor, de intencionalidade persuasiva, exercida nessa fase de dominação-mediação / controle-assunção, é, pois, a responsável pelo gerenciamento da articulação do sensível com o inteligível anterior à interpretação judicativa final; é ela que, ao dirigir, pelo sentir, a configuração da competência epistêmica do enunciatário-auditório, delineia o seu modo de assunção enunciativa, ao qual está condicionada a sanção. Essa ação do enunciador sobre o conteúdo do discurso, em uma perspectiva mais produtiva, isto é, operatória, pode ser, por sua vez, formalizada com base na relação predicativa que o componente figural (tensivo) estabelece com o componente figurativo (temático), determinando as características quali e quantitativas da composição isotópica procedente deste último.

Em outras palavras, na intenção de controlar o pathos do enunciatário, intimamente atrelado à apreensão (sensível-inteligível) do enunciado manifestado, dos efeitos de sentido produzidos, o enunciador-orador submete a dimensão figurativa, que concretiza, no nível discursivo, a categoria semântica de base do nível profundo, a um fluxo perceptível modulado em termos de intensidade e extensidade, conforme acontece na interação entre os constituintes e os expoentes formulação emprestada de Hjelmslev (1985). Na perspectiva da semiótica, como explica Fontanille (1999, p. 75 ${ }^{103}$ ), “os constituintes são as unidades discretas da predicação frástica ou narrativa; os expoentes, as modulações contínuas da presença discursiva sob o controle de uma enunciação". Embora essa homologação teórica tenha sido feita para pensar a interdependência das modalidades com a tensividade na dimensão afetiva do discurso, acreditamos que ela é válida também para pensá-la na relação do figural com o figurativo.

O figural, sendo a dimensão de gerenciamento da percepção do enunciatário durante o processo de configuração da significação, no qual a apreensão sensível do conteúdo se articula à formulação inteligível subsequente, delineia, pela correlação da intensidade com a extensidade, o grau de presença, de tonicidade, das duas grandezas opositivas manifestadas pela figuratividade, sensibilizando as

l'auditeur; c'est d'une opération de maîtrise qu'il s'agit."

103 Trecho original: "[...] les constituants sont les unités discrètes de la prédication phrastique ou narrative; les exposants sont les modulations continues de la présence discursive, sous le contrôle d'une énonciation." 
diferentes possibilidades de relação semântica (de semelhança ou de contraste dos conteúdos em jogo). Nesse sentido, dois regimes de confrontação segundo a intensidade do acento emocional podem distinguir-se: um intenso e outro distenso.

0 primeiro regime (intenso) é resultado da concentração da intensidade no desenvolvimento figurativo, através da inflexão de tonicidade acelerada em uma das grandezas opositivas, em uma das linhas argumentativas, ou no contraste entre elas. É o que acontece na primeira parte do conto "Negrinha”, de Monteiro Lobato, cuja dimensão figurativa, não expandindo o campo discursivo no qual se dá a tensão entre os valores de benevolência e crueldade, funciona como inflexão de tonicidade deste último, chamando a atenção para a ausência do valor euforizado. Ao enfatizar o contraste entre tais universos semânticos, é a discrepância entre eles, com o acento de sentido colocado sobre o valor disfórico, que sensibiliza o olhar do enunciatário-leitor na sua relação com Negrinha, despertando nele ora a piedade, ora a compaixão.

O segundo regime (distenso) procede de uma estratégia contrária, que privilegia a distribuição da tensão entre os valores opostos ao longo do desenvolvimento figurativo. Os valores surgem no campo discursivo, através da figuratividade, de forma desacelerada, atonizando a sua força de impacto e permitindo, dessa forma, uma assimilação mais inteligível do ponto de vista argumentativo defendido. Trata-se da estratégia adotada em "Conversa de bois", de Guimarães Rosa, no trecho em que se narra a morte do pai de Tiãozinho. Nessa cena, os valores semânticos subjacentes à figuratividade emergem no discurso pouco a pouco, em paralelo à expansão figurativa que abre os horizontes do espaço tensivo, distribuindo na extensidade a tensão. Daí a interação afetiva entre enunciatário-leitor e ator do enunciado ser de ordem mais inteligível que propriamente sensível, provocando a piedade e não exatamente a compaixão.

A dinâmica figural permite, dessa forma, a regulação do grau de envolvimento afetivo do sujeito da recepção. Como explica Fontanille (2002b, p. $\left.100^{104}\right)$ :

104 Trecho original: “[...] esta conjugación sistemática de un desplazamiento de intensidad y de un cambio en la extensión de una figura dada condiciona, a la vez, la percepción de la presencia configuracional del segmento textual, y la del valor de la figura: conduce, por lo tanto, a la 'resolución interpretativa' por la mediación de un efecto de configuración." 
[...] essa conjugação sistemática de um deslocamento da intensidade e de um remanejamento na extensão de uma dada figura [ou um argumento] condiciona, ao mesmo tempo, a percepção da presença configuracional do segmento textual, e aquela do valor da figura [ou do argumento]: ela conduz, então, pela mediação de um efeito de configuração, à "resolução interpretativa".

Assim, as estratégias de dominação e controle a serem assumidas pelo enunciador-orador na produção de seu discurso assentam-se - conforme propõe Zilberberg $(1998 ; 2012)$-, segundo o tratamento discursivo dado aos termos da categoria semântica de base, em:

(i) uma sintaxe intensiva, que, operando por aumentos e diminuições, determina o acento de sentido, o grau de tonicidade perceptiva de cada uma das isotopias correspondentes às grandezas em cena;

(ii) uma sintaxe extensiva, própria às triagens ou misturas figurativas e, por conseguinte, à abertura ou ao fechamento do campo tensivo no qual atua a categoria semântica subjacente;

(iii) uma sintaxe juntiva, que, subsumindo os dois outros tipos de predicação sintáxica da tensividade, responde pelo que Fontanille chama em seu artigo (2002b) "modalidades da confrontação"; ela regula a maneira como as grandezas oponentes se relacionam entre si no desenvolvimento discursivo: por concessão, aumentando a densidade de presença da tensão em um campo de atuação circunscrito, e produzindo, ao mesmo tempo, um efeito de sentido tônico, regido sobretudo pela convocação sensível do enunciatário-auditório; ou por implicação, diminuindo a densidade de presença da tensão pela abertura do campo, e suscitando, assim, um efeito de sentido átono, com maior 
proeminência do inteligível.

No que diz respeito ao modo de funcionamento dessas instâncias predicativas no interior dos discursos, Zilberberg (1998, p. $203^{105}$ ) explica:

Se cada uma dessas predicações apresenta um interesse em si, são sobretudo as relações que devem chamar a atenção. Se admitirmos que elas têm por direção a diferença, a presença e o impacto, respectivamente, a questão será vislumbrar as relações de dependência entre essas categorias. Sublinhemos, de início, que o discurso não encontra obstáculos naquilo que chamaríamos a "pluralidade de suas vozes": passar de uma a outra por sucessão, ajustá-las entre si por simultaneidade, eis precisamente o que ele faz.

O agenciamento sintáxico-predicativo, ou de configuração, nos termos de Fontanille (2002) - regente das categorias discursivas destacadas anteriormente intensidade, quantidade, conflito e assunção - responde, pois, pelo processo de sensibilização emocional, ou, mais especificamente, pela produção progressiva do "valor do valor" responsável pela patemização da interpretação epistêmica subjacente à sanção final. É através dele que, nesse percurso, o enunciador-orador submete o "crer sancionador" ao "sentir competencializante". Nesse sentido, a fase de dominação-mediação / controle-assunção - própria ao modo como o discurso se apresenta ao enunciatário-auditório, convocando-o em sua sensibilidade e inteligibilidade - age diretamente na fase seguinte, de resolução, de modo interpretativo.

Essa última etapa do esquema canônico retórico, concebido como "um modelo da práxis enunciativa, da dimensão retórica do discurso" (FONTANILLE, 2002 b, p. $107^{106}$ ), corresponde, dessa forma, em nossa interpretação, à sanção, ao modo de assunção enunciativa do enunciatário-auditório em relação ao conteúdo

105 Trecho original: "Si chacune de ces prédications présente un intérêt par elle-même, ce sont surtout leurs relations qui doivent retenir l'attention. Si nous admettons qu'elles ont pour direction respectivement la différence, la présence et l'éclat, il s'agit d'entrevoir les relations de dépendance entre ces catégories. Il convient d'abord de souligner que le discours, lui, n'est pas embarrassé par ce que nous aimerions appeler la 'pluralité de ses voix': passer de l'une à l'autre par succession, les ajuster entre elles par simultanéité est justement son affaire."

106 Trecho original: “[...] un modelo de la praxis enunciativa, de la dimensión retórica del discurso $[\ldots] . "$ 
do discurso, à linha argumentativa defendida. É o momento em que se manifesta, e se configura com maior exatidão o "valor do valor" em ambos os pontos de vista. Trata-se, portanto, da fase em que se conciliam ou se confrontam os posicionamentos assumidos pelos sujeitos da enunciação (de um lado o enunciador e de outro o enunciatário); a etapa em que se pode avaliar a eficácia do discurso, das estratégias discursivas adotadas na fase de dominação-mediação para o gerenciamento do pathos do enunciatário-auditório.

A dimensão retórica do discurso é, nesse sentido, aquela na qual a interrelação entre produção e recepção do discurso, entre éthos, pathos e logos (enunciador, enunciatário e enunciado) mais se evidencia, chamando a atenção para a fluidez das fronteiras que separam uma e outra instância e para o papel central do enunciatário-auditório na elaboração discursivo-textual. Além disso, é também nela que a articulação entre sensível e inteligível mostra a sua coerência, o seu valor operatório, o seu valor estético-persuasivo. Isso importa porque, conforme bem ressalta Mathieu-Castellani (2000, p. $8^{107}$ ), retomando Benveniste, “todo discurso espera persuadir, e a expressão 'discurso persuasivo' é na verdade um pleonasmo, uma vez que, como o diz E. Benveniste, todo discurso busca influenciar o outro [o enunciatário] de alguma maneira".

De toda forma, se essa nova interpretação do esquema retórico canônico, idealizada como modelo de análise do processo de patemização da recepção dos discursos, concebidos, por sua vez, como uma rede estruturada de diferenças a partir das quais emergem os valores, permite a depreensão da dinâmica figural (lógica tensiva) subjacente à produção dos efeitos de sentido passionais, ela precisa, todavia, para dar conta da peculiaridade dos estados de alma já categorizados culturalmente, combinar-se às determinações figurativas, e mesmo icônicas, impostas pelo uso a cada uma das paixões. Afinal, como postulado por Aristóteles em sua Arte Retórica (s/d, p. 97), "convém distinguir três coisas, relativamente a cada paixão", não só em que disposições (discursivas) somos incitados a essa ou aquela paixão, mas a quem as dirigimos, quais as causas que as

107 Trecho original: “[...] tout discours entend persuader, et la formule 'discours persuasif' n'est rien d'autre que pléonasme, puisque, comme le dit E. Benveniste [1966, Problèmes de linguistique générale, p. 241-242], toute parole vise à influencer l'autre [l'auditeur] de quelque manière." 
provocam; e ele enfatiza (p. 98): "se uma ou duas destas noções nos escapam e se não as conhecemos todas, encontramo-nos na impossibilidade de suscitar a coléra [por exemplo] no ânimo dos ouvintes".

É por isso que, longe de valorizar o ponto de vista semiótico, em que se privilegiam as inter-relações sintáxico-semânticas subjacentes aos fenômenos passionais, em detrimento aquele da retórica, mais ligado às observações de ordem ético-cultural dos afetos, nossa intenção, ao buscar compreender sintaxicamente a lógica interna das configurações passionais, é a de salientar a produtividade do diálogo entre as duas disciplinas, o qual deve ser estabelecido em termos de complementaridade.

Assim como o domínio da dinâmica tensiva (figural) não basta, se não estiver atrelado ao conhecimento de suas determinações icônicas (figurativas), para poder incitar essa ou aquela paixão no enunciatário-auditório; da mesma forma, apenas saber quais os tipos de argumentos que o levam à disposição passional desejada também não é o suficiente se não se puder recriar, discursivamente, a sua força de impacto, o seu poder de sensibilização, mais sensível ou mais inteligível, como melhor convier. Citando uma vez mais MathieuCastellani (2000, p. $77^{108}$ ), que corrobora essa observação: “o orador deve saber que os melhores argumentos não terão eficácia alguma para determinar a ação que se deseja incitar (uma decisão), se ele não toca seu auditório".

\subsection{Retórica, Poética e Semiótica: o interesse pela produção dos efeitos de sentido}

Uma das grandes contribuições dos tratados aristotélicos que serviram, e ainda servem, de modelo para muitos, principalmente no que se refere a sua Arte Retórica e a sua Arte Poética, parece-nos ser o estabelecimento de um estudo sistemático do discurso, um metadiscurso, a partir do qual o Estagirita - aliando técnica, ciência, ensino, moral e prática social - tenta depreender a lógica interna das produções textuais, o seu funcionamento, sem deixar de considerar a sua força

108 Trecho original: “[...] l'orateur est averti que les meilleurs arguments n'auront aucune efficacité pour déterminer l'action qu'il souhaite inspirer (une décision) s'il ne touche pas son auditoire." 
de influência, o seu poder de sensibilização.

Tendo como ponto de partida três questões de base, que aparecem já nas primeiras páginas da Retórica: quem fala? para quem fala? sobre o quê?, Aristóteles funda suas reflexões na atividade discursiva, colocando lado a lado a produção e a recepção dos textos, uma condicionando e determinando, mutuamente, a outra. Importava ao filósofo grego, como demonstram os seus tratados, explicitar a interrelação entre esses "pilares" do sistema interno do discurso, do seu processo de composição, para o qual, mais do que o que é dito, interessam as "leis" ideais ao modo de dizer.

Os efeitos de sentido então configurados, que devem garantir a adesão do enunciatário-auditório, mostram, dessa forma, a sua efetividade nos apontamentos aristotélicos. Embora os dois tratados mencionados anteriormente tenham objetivos teóricos distintos - a Retórica interessada no que gera a persuasão; a Poética, na especificidade das produções artísticas, literárias -, há, ainda assim, um princípio comum que as une a um só interesse: o de estabilização dos procedimentos discursivos subjacentes à dinâmica de produção dos efeitos de sentido, com os quais se pode avaliar a eficácia persuasiva e/ou poética do enunciado em questão. A esse respeito Aristóteles declara (s/d, p. 271):

0 que diz respeito ao pensamento tem seu lugar nos Tratados Sobre Retórica, pois este gênero de investigações é seu objeto próprio. Tudo quanto se exprime pela linguagem é do domínio do pensamento. Disso fazem parte a demonstração, a refutação, a maneira de mover as paixões, tais como a compaixão, o temor, a cólera e as restantes. É evidente que devemos empregar estas mesmas formas, a propósito dos fatos, sempre que precisamos de os apresentar como comoventes, temíveis, importantes, verossímeis.

A semiótica de linha francesa, por sua vez, entre as teorias contemporâneas dedicadas ao estudo do discurso e, por isso mesmo, herdeiras dos ensinamentos deixados por Aristóteles, tem também, desde o seu surgimento, voltado a sua atenção à estrutura interna dos enunciados, buscando compreender o percurso gerativo que sustenta a sua significação. Todavia, diferente da perspectiva retórica, e mesmo poética, que, para isso, tomou como princípio de base a tríade éthos, 
pathos e logos, a semiótica greimasiana privilegiou o logos, o discurso, atribuindo ao éthos e ao pathos - ao enunciador e ao enunciatário, ambos sujeitos da enunciação - o estatuto de pressuposto lógico simplesmente.

Se esse "recorte", em nome do princípio de imanência, trouxe ganhos inegáveis ao desenvolvimento teórico-metodológico da teoria, que chegou à constituição de uma gramática discursiva geral, a questão da produção dos efeitos de sentido em sua relação com a enunciação propriamente dita ficou, a nosso ver, encoberta, e com ela a operacionalidade implícita aos pares enunciação-enunciado, produção-recepção dos textos, também passíveis de um estudo sistemático assentado no ponto de vista imanentista. Tanto é que, essa delimitação do campo de interesse da semiótica do discurso ao enunciado manifestado tem, desde o final dos anos 1980, cedido espaço a inquietações mais voltadas à problemática da enunciação, do discurso em ato, das condições de emergência da significação; e é aí que se mostra, mais uma vez, a produtividade do diálogo suscetível de ser estabelecido com os ensinamentos aristotélicos presentes não só em sua Arte Retórica, mas também em sua Arte Poética, para lançar luz ao estudo do enunciatário $^{109}$, da recepção dos efeitos de sentido patêmicos produzidos pelo enunciador a partir do enunciado.

Quando pensadas em conjunto, a retórica e a poética aristotélicas - como o faz também a semiótica do discurso -, enquanto reflexões sobre o funcionamento dos textos, do que está por trás dos efeitos de sentido produzidos, deixam de lado a peculiaridade de seus objetos de análise, a argumentação persuasiva e a atividade artística, literária, respectivamente, para chamar a atenção ao processo de elaboração da significação através da linguagem, à (re)criação discursiva do mundo, das situações, caracterizados por impressões a partir das quais não só a inteligibilidade, mas também a sensibilidade, devem ser convocadas (e agir juntas) no momento da recepção, do contato do enunciatário-auditório com o conteúdo que lhe é transmitido. Nesse propósito, dois conceitos forjados na discussão do

109 Cientes da existência dos trabalhos realizados por Umberto Eco nessa direção (1962, 1979, 1990, 1992), estamos nos referindo aqui, e nos restringindo em nossas observações, não exatamente a uma teoria da interpretação, do leitor modelo (ou ideal) como ele faz, mas, mais especificamente, no domínio da semiótica de linha francesa, de origem greimasiana, à configuração da interação tímico-estésica que o enunciatário estabelece com o texto. 
Estagirita sobre a arte poética atuam em comunhão: as noções de mimésis e de catharsis.

A mimésis, "pilar central da teorização de Aristóteles sobre a prática de linguagem, não somente na Poética, mas também em outros textos como a Retórica e a Política" (DESSONS, 1995, p. $17^{110}$ ), refere-se à atividade criativa ela mesma, a uma operação constitutiva do discurso em sua totalidade, como "artefato", com o desenvolvimento discursivo se organizando em função da necessidade interna da produção, isto é, com vistas aos efeitos de sentido a serem a partir dela suscitados.

Segundo Dessons (Idem, p. $24^{111}$ ):

A mimésis de Aristóteles concerne ao trabalho literário enquanto forma de mediação entre a linguagem e o mundo, entre o sentido e o mundo, remetendo a significação ao poeta e não ao mundo. 0 trabalho do poeta não é, portanto, apenas uma simples duplicação, vetor de uma realidade já significante, mas sim criação, elaboração de uma significação que é o processo mesmo de sua arte.

Não se limitando ao conteúdo a que remete, ao dito, mas sobretudo a uma forma de representação, a mimésis responde, nesse sentido, mais exatamente, pela colocação em discurso do conteúdo (narrativo), isto é, pelo modo de dizer que gerencia a sua apreensão. A eficácia discursiva, ou poética, reside, assim, no texto ele mesmo, na significação que se configura a partir desse modo de dizer, de apresentar os fatos. Ao ressaltar que "a imitação é produzida por meio do ritmo, da linguagem e da harmonia, empregados separadamente ou em conjunto", Aristóteles (s/d, p. 239), sempre atento à conveniência de influir nos ânimos do auditório para garantir a sua adesão, parece querer, com a discussão em torno da ideia de mimésis, chamar a atenção para o fato de que não deve importar ao enunciador, seja ele o poeta (o artista) ou o orador, o compromisso com a chamada realidade, mas sim com a produção de uma impressão, de um efeito (sensível, isto é, tímico-

110 Trecho original: “[...] le pilier central de la théorisation d'Aristote sur la pratique du langage, non seulement dans la Poétique, mais également dans d'autres textes comme la Rhétorique et la Politique."

111 Trecho original: "La mimèsis d'Aristote concerne donc le travail littéraire en tant qu'il est une médiatisation entre le langage et le monde, entre le sens et le monde, mettant la signification du côté du poète, et non du côté du monde. Le travail du poète n'est plus alors de simple duplication, vecteur d'une réalité déjà signifiante, mais bien de création, d'élaboration d'une signification qui est le processus même de son art." 
estésico) de realidade. Nesse ponto é que a noção de mimésis reporta-se não apenas àquela de poiése, mas também à de catharsis.

O conceito de catharsis, pouco esclarecido pelo filósofo grego em questão, ficou, de toda maneira, amplamente conhecido em sua acepção clássica de "purgação das paixões", enfatizando a importância da produção, pela mimésis, de efeitos de sentido que mobilizem o enunciatário-auditório garantindo a sua adesão ao discurso. Nas palavras de Dessons (1995, p. $33^{112}$ ):

Podemos perfeitamente conceber a catharsis em uma perspectiva que - para além do alcance hedonista do prazer experimentado pelo conhecimento representativo - visa uma teoria geral do "agradar". De fato, o que venha a ser "agradar"? e o que faz "agradar"? A questão é, na realidade, a da eficiência da arte ou da literatura sobre o espectador ou sobre o leitor, "agradar" sendo aqui um termo genérico para "interessar", "tocar". Essa questão encontra sua resposta na mimésis como processo acabado, como colocação em sistema dos fatos, das emoções, das paixões, isto é, como sua ascensão à significação através de uma criação.

É por isso que a compreensão da catharsis é indissociável da concepção de mimésis.

O discurso é, pois, o lugar (de representação) e o operador do sentir. É o trabalho (discursivo) realizado pelo poeta, pelo enunciador em geral, que faz surgir a catharsis, entendida aqui como a manifestação do máximo de envolvimento afetivo, ou seja, de convocação sensível operada pelo discurso ele mesmo sobre o enunciatário-auditório, "uma relação direta de duplicação, de identificação entre a paixão que se mostra [discursivamente] e a paixão que se experimenta [no momento da recepção]" (Idem, p. $34^{113}$ ).

Nessa perspectiva, que atrela o efeito catártico ao processo mimético de (re)criação de uma situação passional, e, por consequência, a recepção à produção

112 Trecho original: "On peut tout à fait concevoir la catharsis dans une perspective qui, au-delà même de la portée hédoniste du plaisir éprouvé par la connaissance représentative, vise une théorie générale du 'plaire'. En effet, qu'est-ce que 'plaire'? et qu'est-ce qui fait 'plaire'? La question est en fait celle de l'efficience de l'art ou de la littérature, sur le spectateur ou sur le lecteur, 'plaire' étant ici un terme générique pour 'intéresser', 'toucher'. Cette question trouve sa réponse dans la mimèsis comme processus décroché, comme mise en système des faits, des émotions, des passions, c'est-à-dire comme leur accession à la signification à travers une création. C'est en cela que la compréhension de la catharsis est indissociable de la conception de la mimèsis."

113 Trecho original: "[...] une relation directe de duplication, d'identification entre la passion montrée et la passion éprouvée [...]." 
discursiva, parece ficar claro que a eficiência poético-persuasiva remete diretamente à conveniência da articulação do inteligível com o sensível, da configuração (cognitiva) do sentido aos efeitos (patêmicos) que ele deve suscitar no instante de sua apreensão.

Retornamos, dessa forma, à questão do gerenciamento do pathos por parte do enunciador-orador, percebendo, desta vez, mais claramente, que a lógica implícita ao processo de sensibilização do conteúdo a ser transmitido, da sua patemização, é, por consequência, a mesma para a compreensão (formalizada) da resposta afetiva manifestada pelo enunciatário-auditório. Da mesma maneira como este último exerce uma influência direta sobre as escolhas e estratégias assumidas pelo enunciador, com vistas à eficácia discursiva, quando da produção de seu enunciado - seja ele de que tipo for -, tais procedimentos, determinando, como vimos, o modo de acesso ao conteúdo, caracterizam também, pelos efeitos de sentido que se criam, a recepção, o modo de assunção enunciativa do enunciatário.

A produção discursivo-textual, de responsabilidade do enunciador, ao responder pelos efeitos de sentido que a partir dela se configuram, é, segundo nos parece pertinente pensar, a manifestante da recepção patêmica por parte do enunciatário, sendo esta a manifestada. Como nível pressuposto, a produção predica a recepção, seu pressuponente, o modo de interação, mais sensível ou mais inteligível, do enunciatário com o texto.

Em paralelo a isso, e com base no que foi discutido no tópico anterior deste mesmo capítulo, podemos dizer que a tensividade, ou melhor, a predicação tensiva, para sermos mais exatos, é, por sua vez, a manifestante da convocação sensível, da estesia, que é a manifestada. Ao responder pela produção dos efeitos de sentido, mais sensíveis ou mais inteligíveis, a dinâmica tensiva regula o modo de assunção enunciativa do enunciatário, permitindo, por isso mesmo, como buscamos demonstrar nas análises realizadas no capítulo três, um exame formal de sua configuração, da articulação do sensível com o inteligível no momento da recepção.

Tais constatações, talvez, a essa altura, um tanto evidentes, interessam por salientar que a interação tímico-estésica do enunciatário em sua relação com o discurso - concebida como resposta à convocação sensível operada pelo 
enunciado, pelos efeitos de sentido por ele provocados - não é exterior ao texto, estando, ao contrário, intrinsecamente relacionada a ele, ao seu processo de composição. Isso legitima, a nosso ver, a análise propriamente semiótica desse tipo de recepção, enfatizando a coerência, e a produtividade, da apropriação semiótica de noções como corpo, percepção, presença (ou campo de presença), etc., todas tomadas de empréstimo, de maneira conveniente, à teoria fenomenológica.

Ademais, essa perspectiva torna possível o estabelecimento de critérios estruturais de análise (conforme tentamos - apoiados nos desenvolvimentos da semiótica tensiva - propor ao longo da tese) suficientemente gerais para o exame da interação patêmica do enunciatário com qualquer tipo de texto, seja ele verbal ou não verbal - cientes de que, no caso deste último, a demonstração resta a fazer. 
CONClUSÃo 
Se ainda cremos no velho adágio segundo o qual é o ponto de vista solidamente mantido que constitui um domínio qualquer em

"disciplina" e lhe confere o status de objeto de pesquisa, é mesmo esse espaço semiótico povoado de formas cognitivas patemizadas, em que o racional e o irracional se fundiram em racionalidades diversas e em configurações patêmicas múltiplas, que é o lugar homogêneo de nossas explorações.

A. J. Greimas e J. Fontanille

\section{Recapitulação, avaliação e desdobramentos}

Quando iniciamos esta pesquisa, duas questões nos inquietavam: (i) o fato de o modelo de análise proposto pela semiótica das paixões continuar - depois dos desenvolvimentos em direção à problemática do sensível - assentado somente no exame da estrutura modal que sustenta a interação passional, desconsiderando o componente tensivo a ela subjacente e responsável por sua patemização; e (ii) a curiosidade em relação aos possíveis determinantes dos diferentes modos de interação afetiva, ora mais sensíveis, ora mais inteligíveis, estabelecidos com o mundo ao redor, com aquilo que se apresenta em nosso campo de percepção e que traduzimos como objeto significante. Em ambos os casos, interessava-nos chegar a uma compreensão das condições de emergência dos afetos, das peculiaridades do processo de configuração da relação intersubjetiva, bem como poder sugerir um percurso de investigação atualizado, atento às proposições voltadas à enunciação, ao sensível, ao discurso em ato, assim como às já previstas anteriormente no plano do discurso enunciado.

Esses objetivos surgiram em paralelo a nosso desejo de compreender o que exatamente responde pela diferença qualitativa entre os estados de alma de compaixão e piedade, tomados muitas vezes, pela estrutura narrativa comum, como paixões sinônimas, mas dizendo respeito, segundo cremos, a modos de interação afetiva distintos, com o primeiro ${ }^{114}$ - de acordo com a tradição ocidental - mais ligado a um "sentir com", de natureza mais sensível e espontânea, e o

114 A pesquisa apresentada aqui representa a continuidade e o aprofundamento de hipóteses levantadas ao final do mestrado (2010), quando nos dedicamos ao estudo, também na perspectiva da semiótica da Escola de Paris, das especificidades da produção do efeito passional de compaixão em textos de diferentes gêneros discursivos. 
segundo, a um "sentir por", de natureza mais inteligível e social. É aí que as duas frentes de trabalho se cruzam e unem, esperamos, o necessário ao elucidativo.

Cientes, então, de que "a paixão não é concebível sem o valor: valor investido nos objetos, axiologias descritivas, obviamente, mas, sobretudo, valores modais e aspectuais, controlados pelas valências tensivas" (FONTANILLE; ZILBERBERG, 2001, p. 313), e de que, assim, “a dimensão passional dos discursos é indissociável do devir das axiologias" (Idem, ibid), começamos a pensar na hipótese de a "chave" para tais indagações estar centrada na noção de percepção - entendida aqui como ato de semiose no qual sensível e inteligível, a partir das modulações do campo perceptivo, atuam em conjunto. Tal ponto de vista, caso ficasse comprovada a sua legitimidade, parecia-nos profícuo por assinalar a possibilidade de extensão da análise semiótica das paixões mesmo para textos não-verbais, nos quais a depreensão da estrutura modal é bem menos operatória.

Por ser a atividade perceptiva nossa primeira forma de contato com a presença que nos convoca (de maneira mais sensível ou mais inteligível), víamos o modo de apreensão dos valores nela investidos como o possível condicionante do modo de junção (conjunção, disjunção, não-conjunção, não-disjunção), isto é, do modo de interação afetiva desencadeado (fusão, cisão, desprendimento, aproximação). Nessa perspectiva, as modulações tensivas seriam, pois, as responsáveis pelas condições de estabelecimento da interação entre o sujeito da percepção e o objeto-valor percebido, respondendo, dessa forma, pelo modo de convocação operado e, por conseguinte, pelo modo de articulação do sensível com o inteligível na configuração da intersubjetividade. Importava, nesse sentido, encontrar um meio de depreender semioticamente esse devir da interação, da situação de apreensão (sensível-inteligível) dos valores da presença.

Para essa tarefa, as proposições da semiótica tensiva foram de fundamental importância, não apenas por oferecer o expediente necessário à (re)formulação dos modelos de análise, mas sobretudo por ter chamado a nossa atenção à parceria firmada entre sensível e inteligível nos processos de geração da interação e, a partir dela, da significação de maneira geral, e ao papel de destaque desempenhado pela tensividade na determinação do modo de articulação dessas duas dimensões de 
apreensão da presença.

Compreendemos, e as análises realizadas comprovaram, que, de fato, a predicação tensiva da presença prescreve as circunstâncias de interação entre esta e o sujeito da percepção. Conforme variem os graus de intensidade e de extensidade do objeto percebido - logo, do campo de coexistência interactancial diversificam-se também o modo de convocação do sujeito perceptivo e, consequentemente, o seu modo de interação com os valores caracterizantes da presença.

Essa interpretação formalizada do processo de interação que faz surgir as paixões, ao viabilizar o estabelecimento de uma sintaxe elementar dos modos de interação afetiva, trouxe à tona, ao mesmo tempo, a perspectiva de uma categorização progressiva e contínua dos afetos, passíveis de ser classificados a partir do grau de afetividade que os particulariza. As unidades de medida mais e menos, bem como a sua combinação, ao qualificar a tonicidade perceptiva da presença, apontaram, portanto, para a possibilidade de "medir", ou seja, quantificar essa articulação entre sensível e inteligível, os quais passaram a ser concebidos como pontos de um intervalo dentro do qual se inscreveriam os estados de alma.

Fomos, assim, pouco a pouco, constatando que as paixões, enquanto modos de junção (manifestantes), são, com efeito, respostas a certo modo de interagir (manifestado) com o outro, com o valor por ele representado. Produtos do devir intersubjetivo, os estados de alma são resultados do valor tímico (afetivo) que o sujeito apaixonado passa, no processo de interação, a atribuir ao valor axiológico investido no objeto da afetividade. No entanto, mais do que o valor em si, o que sensibiliza, como tentamos demonstrar ao longo da análise dos textos, é o modo como os valores emergem no campo de presença, o modo pelo qual o sujeito da percepção tem acesso a eles.

No caso dos estados de alma de compaixão e piedade, por exemplo, comprovou-se nossa hipótese - levantada a partir da investigação de base lexical de que a diferença (qualitativa) entre esses dois modos complexos de interação afetiva corresponde ao elemento da cena passional sobre o qual recai o acento de sentido; ou seja, manifesta-se o sentimento compassivo quando o acento de sentido 
(de intensidade) incide, no campo de presença, mais exclusivamente sobre o sofrimento do sujeito atingido pelo dano, permitindo ao sujeito da percepção uma assimilação direta do valor axiológico em causa, enquanto o sentimento piedoso diz respeito a uma assimilação indireta do valor, por estar o acento de sentido colocado não sobre o sujeito (objeto da percepção) a que a afetividade provocada se dirige, mas sobre o dano que caracteriza o seu padecimento. Em ambas as situações, o que desperta o afeto, seja o de compaixão, seja o de piedade, é o valor tímico (afetivo) atribuído ao valor axiológico representado pelo sofrimento do outro. A diferença está exatamente no modo como este último emerge no campo de presença: de maneira direta e, por isso, mais impactante; ou de forma indireta, logo, menos impactante.

$\mathrm{Na}$ análise semiótica das paixões ficou-nos claro, portanto, que, para além da interação patêmica estabelecida entre o sujeito da percepção e a presença que o convoca sobretudo em sua sensibilidade (modos primários de interação afetiva), importa atentar, dentro desse conjunto significante percebido, sobretudo ao objeto-valor da afetividade a partir daí produzida (modos complexos de interação afetiva). Foi isso o que nos levou a pensar na presença não como um todo homogêneo, mas como uma unidade de significação passível de ser decomposta em níveis, em expoentes (tensivos, figurais - relacionados à caracterização sensível da presença) e constituintes (figurativos - próprios à dimensão inteligível de sua composição).

Demo-nos conta, especialmente durante o exame do corpus, da intrínseca relação entre a dimensão figurativa e a dimensão figural na disposição da presença discursiva, ou mais especificamente, na concretização dos valores nela investidos, o que salientou, de um lado, a relevância da figuratividade ${ }^{115}$ - e não só da predicação de ordem tensiva, ou da estrutura narrativa subjacente - na produção dos afetos; de outro, a procedência dos efeitos de sentido passionais do todo discursivo: do nível fundamental ao narrativo, e destes ao discursivo; do conteúdo à expressão; do enunciado à enunciação.

Acreditamos ter ficado comprovada, assim, a conveniência de associar o

115 Não estamos nos referindo aqui a uma figuratividade específica, particular, mas sim a possibilidades de combinação sintagmática de ordem mais geral, sintáxica, e, por isso, passível de generalização. 
desenvolvimento teórico-metodológico da semiótica das paixões ao ponto de vista do discurso em ato, da significação em devir, que, não privilegiando nenhum desses níveis de pertinência, os confronta na intenção de depreender a relação instituída entre eles para o gerenciamento da articulação do sensível com o inteligível no momento da interação do sujeito da percepção com o objeto-valor percebido. Como observam Fontanille e Zilberberg (2001, p. 297), “com as paixões, a semiótica deve obter meios de tratar de conjuntos heterogêneos e de dar conta da sua coerência".

É por isso que, uma vez firmadas todas essas premissas, e corroborada, por elas mesmas, a possibilidade de "formalizar" também o componente sensível da significação, esse continuum tensivo subjacente às unidades discretas, buscamos estabelecer uma trajetória de investigação dos afetos capaz de abarcar essa heterogeneidade formante dos núcleos patêmicos, e uma nova interpretação do esquema passional canônico - proposto, de início, por Greimas e Fontanille em Semiótica das paixões (1993) -, na qual não só os dispositivos inteligíveis fossem privilegiados, mas também as especificidades propriamente sensíveis, pareceu-nos produtiva.

Aquém das combinações modais, que traduzem o modo complexo de interação afetiva manifestado, designadas à etapa final do processo de configuração das paixões (fase da moralização - terminativa), procuramos instituir justamente as fases anteriores, equivalentes ao exame das condições de emergência da afetividade, indo da instauração do campo de presença interactancial (fase da constituição - incoativa) ao gerenciamento da densidade de presença dos valores em questão e, consequentemente, do modo de convocação (sensível-inteligível) do sujeito da percepção (fase da sensibilização - durativa).

Não se trata, contudo, - conforme tentamos demonstrar nas análises realizadas - de apresentar um esquema a ser aplicado mecanicamente, mas sim um percurso de discretização do devir da relação intersubjetiva que delineia a paixão examinada. 0 que de fato importa é chamar a atenção do analista tanto às determinações sintáxicas subjacentes à emergência da interação afetiva em causa, e, com isso, à operacionalidade das noções emprestadas - de maneira peculiar, ou seja, semiotizada - da teoria fenomenológica, como percepção, presença, sensível e 
inteligível, quanto à complexificação que vai das primeiras somações (sensíveis) à resolução (inteligível), à produção do "valor do valor", base da intersubjetividade.

Essa outra forma de abordagem dos afetos nos pareceu válida por permitir uma investigação da função constitutiva dos estados de alma, ou seja, da junção (ou do modo de junção) que une o sujeito ao objeto, não apenas em sua pontualidade efetiva, como produto, mas em sua duração, como um percurso gerativo aspectualizado. Além disso, com esse intuito - dada a perspectiva do discurso em ato - de lançar luz sobre o processo, para melhor compreender as especificidades dos resultados dele procedentes, a proposição de um esquema canônico, articulado em fases sucessivas de concretização discursiva, afigurou-se como a melhor maneira de esboçar a organização estrutural da interação, da sua progressão, o que nos levou a adotá-lo também como modelo de análise na ocasião da discussão sobre a semiotização da retórica das paixões, quando, ao considerar tanto a produção do enunciado quanto a sua interpretação como atos de semiose, tentamos demonstrar a possibilidade de formalização do efeito tímico-estésico procedente da dimensão passional dos discursos.

Em suma, na tentativa de expor a possibilidade de formalização do sensível, mais, do exame de sua articulação ao inteligível nos processos de interação, de geração da significação, esperamos conseguir, ao menos, reacender o interesse pela semiótica das paixões, que depois de ter marcado uma nova fase dentro do quadro geral da teoria, enfatizando a necessidade de depreender não só as unidades discretas do percurso de geração do sentido, mas também as condições de sua emergência, continuou - salvo algumas poucas proposições isoladas, sem grande repercussão entre os semioticistas de maneira geral - limitada às suas aquisições iniciais, ao modelo de análise com base narrativa, constantemente criticado por deixar de fora justamente as peculiaridades próprias ao sentir, fulcro da passionalidade, da experiência estésica e estética.

Para além do exame das paixões enunciadas, poder depreender e avaliar, a partir da análise dos textos, as condições de produção dos efeitos de sentido passionais nos parece um passo importante para a teoria, que passa a oferecer uma metodologia coerente para o estudo, dentro da perspectiva semiótica, não só da 
significação atualizada pelo enunciador, quando da produção do enunciado, mas inclusive da significação realizada pelo enunciatário, no instante do seu contato com o texto. É aí, segundo cremos, que, ancorados no discurso enunciado e manifestado por uma linguagem qualquer, e tomando-o como ponto de partida, temos as melhores condições de observar o modo como a tríade enunciador, enunciado, enunciatário interage no processo de geração do sentido.

"Vivendo, se aprende; mas o que se aprende, mais, é só a fazer outras maiores perguntas."

(G. Rosa - Riobaldo, em Grande Sertão: Veredas) 
REFERÊNCIAS BIBLIOGRÁFICAS 
ARISTOTELES. Arte retórica e arte poética. Trad. Antônio Pinto de Carvalho. Rio de Janeiro: Ediouro, s/d.

BARROS, D. L. P. de Teoria do discurso. Fundamentos semióticos. São Paulo: Humanitas, 2001.

. Semiótica e interação. In: ; ESPAR, T. (coords.) Perfiles Semióticos. Greimas en América Latina: Bifurcaciones. Revista de Estudios Semiolinguísticos, año 1, no 1, Mérida, Venezuela: Ediciones del Rectorado, 2003, p. 119-136.

BECKER, E. R. Forças motrizes de uma contística pré-modernista: o papel da tradução na obra ficcional de Monteiro Lobato. Tese de Doutorado do programa de pós-graduação em Letras, da Universidade Federal do Rio Grande do Sul, 2006, 183 páginas.

BEIVIDAS, W. A dimensão do afeto em semiótica: entre fenomenologia e semiologia. In: MARCHEZAN, R. C.; CORTINA, A.; BAQUIÃO, R. C. (orgs.) A abordagem dos afetos na semiótica. São Carlos: Pedro \& João editores, 2011, p. 13-33.

BERTRAND, D. (coord.) Actes sémiotiques. Bulletin, XI, no 39, 1986.

. Caminhos da semiótica literária. Trad. Grupo CASA, sob a coordenação de Ivã Carlos Lopes et al. Bauru: EDUSC, 2003.

. Thymie et enthymeme. In: FONTANILLE, J. Les émotions: figures et configurations dynamiques. Revue Semiotica, volume 163, 1/4, 2007, p. 75-84.

BORDRON, J-F. Perception et énonciation dans l'expérience gustative. In: HÉNAULT, A. (dir.) Questions de sémiotique. Paris: PUF, 2002, p. 639-665.

; FONTANILLE, J. Introduction. In: . (dir.) Tensions rhétoriques et sémiotique du discours. Revue Langages, numéro 137, 2000, p. 3-15.

COELHO, M. L. G. O arranjo como elemento orgânico ligado à canção popular brasileira: uma proposta de análise semiótica. Tese de Doutorado do programa de pós-graduação em Semiótica e Linguística geral, FFLCH/USP, 2007, 226 páginas.

COUTINHO, E. Guimarães Rosa: um alquimista da palavra. In: ROSA, J. G. Ficção completa. Vol. 1, 1a ed., Rio de Janeiro: Nova Aguilar, 1994, p. 9-23.

DESSONS, G. Introduction à la poétique. Approche des théories de la littérature. Paris: Nathan Université, 1995.

DISCINI, N. Um algoritmo da percepção: o sujeito do afeto. In: MARCHEZAN, R. C.; CORTINA, A.; BAQUIÃO, R. C. (orgs.) A abordagem dos afetos na semiótica. São Carlos: Pedro \& João editores, 2011, p. 149-172. 
. Estilo e corpo. Tese de Livre Docência, FFLCH/USP, 2013, 387 páginas.

ECO, H. Notes sur la sémiotique de la réception. Actes Sémiotiques. Documents, IX, no 81, Paris, CNRS, 1987.

. Interpretação e Superinterpretação. São Paulo: Martins Fontes, 1993. [1992]

. Lector in Fabula: a cooperação interpretativa nos textos narrativos. São

Paulo: Perspectiva, 2004. [1979]

. Os limites da Interpretação. São Paulo: Perspectiva, 2004. [1990]

. Obra Aberta: forma e indeterminação nas poéticas contemporâneas. São

Paulo: Perspectiva, 2005. [1962]

FIORIN, J. L. As astúcias da enunciação. São Paulo: Ática, 2008.

FONTANILLE, J. Le désespoir. Actes Sémiotiques. Documents, II, no 16, Paris, CNRS, 1980.

. Le tumulte modal: de la macro-syntaxe à la micro-syntaxe passionnelle. In: BERTRAND, D. (coord.) Actes sémiotiques, Bulletin XI, nº 39, 1986, p. 12-31.

Les espaces subjectifs: introduction à la sémiotique de l'observateur. Paris: Hachette, 1989.

. Modulations passionnelles. In: WIKTOROWICZ, C. Algirdas J. Greimas et Jacques Fontanille, Sémiotique des passions. Des états de choses aux états d'âme. Études littéraires, vol. 25, n 3, 1993a, p. 153-161.

. Le schéma des passions. Protée, vol. 21, no 1, 1993b, p. 33-41.

. Le tournant modal en sémiotique. Organon, vol. 9, n 23, 1995a. Disponível em: http://www.seer.ufrgs.br/organon/issue/view/1690/showToc Consultado em: 10/01/2013

La base perceptive de la sémiotique. In: HELBO, André (dir.) Dégres. Revue de synthèse à orientation sémiologique. № 81, 1995b, p. a1-a25. 2003].

. Sémiotique du discours. Limoges: PULIM, 1998 [2ª ed. ampliada publicada em Sémiotique et littérature. Paris: PUF, 1999.

. Sémiotique des passions. In: HÉNAULT, A. (dir.) Questions de sémiotique. 
Paris: PUF, 2002a, p. 601-637.

Retórica y manipulación de los valores. Trad. Georgina Gamboa. In:

ZILBERBERG, C. (ed.) Semiótica del valor. Revista Tópicos del Seminario, número 8, 2002b, p. 73-112.

. La participation sensible. Sémiotique de la pitié. In: OUELLET, P. (dir.) Le soi et l'autre. L'énonciation de l'identité dans les contextes interculturels. Canadá : Les Presses de l'Université Laval, 2003, p. 217-237.

Pitié. In: RALLO-DITCHE, E.; FONTANILLE, J.; LOMBARDO, P. Dictionnaire des passions littéraires. Paris : Belin, 2005, p. 240-265.

. Le temps de la compassion. La diffusion thymique et ses régimes temporels. In: HÉBERT, L. (dir.) Le plaisir des sens. Euphories et dysphories des signes. Canadá: PUL, 2006, p. 23-51.

. Semiótica do discurso. Trad. Jean Cristtus Portela. São Paulo: Contexto, 2007.

. Vent'anni dopo. Studiare le passioni oggi. Trad. it. di Cristina Greco. $E / C$, 2012. Disponível em: http://www.ec-aiss.it/archivio/tipologico/autore.php Consultado em: 15/01/2013

.; ZILBERBERG, C. Tensão e significação. Trad. Ivã Carlos Lopes, Luiz Tatit e Waldir Beividas. São Paulo : Humanitas, 2001.

.; TORE, G. M. De la modalisation à l'esthésie: considérations (in)actuelles sur le passage de Du sens à Du sens II. Protée, vol. 34, n 1, 2006, p. 23-32.

GREIMAS, A. J. Pour une théorie des modalités. Langages, n43, 1976, p. 90-107.

. Pour une théorie des passions. Bulletin, nº 6, juin 1978.

. De la colère. Actes Sémiotiques. Documents, III, nº 27, Paris, CNRS, 1981.

. Du sens II. Paris: Seuil, 1983.

. De la nostalgie. Étude de sémantique lexicale. In: BERTRAND, D. (coord.) Actes sémiotiques, Bulletin XI, no 39, 1986, p. 5-11.

. De l'imperfection. Périgueux: Pierre Fanlac, 1987.

. Da imperfeição. Trad. Ana Claudia de Oliveira. São Paulo: Hacker, 2002.

.; FONTANILLE, J. Sémiotique des passions. Des états de choses aux états d'âme. Paris: Seuil, 1991. 
;____ Semiótica das paixões. Dos estados de coisas aos estados de alma.

Trad. Maria José Rodrigues Coracini. São Paulo: Ática, 1993. ;; COURTÉS, J. Dicionário de semiótica. São Paulo : Contexto, 2008.

HÉNAULT, A. Structures aspectuelles du rôle passionnel. In: BERTRAND, D. (coord.) Actes sémiotiques, Bulletin XI, nº 39, 1986, p. 32-42.

. Le débat du 23 mai 1989 entre A. J. Greimas et Ricoeur sur la sémiotique des passions. In: . Le pouvoir comme passion. Paris: PUF, 1994, p. 189-216.

HJELMSLEV, L. La syllabe en tant qu'unité structurale. In: Nouveaux Essais.

Paris: PUF, 1985, pp. 165-171.

HUSSERL, E. Expérience et jugement. Trad. par D. Souche, Paris: PUF, 1970, coll. Épiméthée.

JOUVE, V. L'effet-personnage dans le roman. Paris: PUF, 2001.

KANT, I. Crítica da Razão Pura. Trad. Valério Rohden. São Paulo: Nova Cultural (Coleção Os Pensadores), 1996 [1788].

. Fundamentação da Metafísica dos Costumes e Outros Escritos. Trad. Leopoldo Holzbach. São Paulo: Martin Claret, 2005 [1785].

KLINKENBERG, J.-M. Prefácio. Trad. Lineide do Lago Salvador Mosca. In: MOSCA, L. L. S. Retóricas de ontem e hoje. São Paulo: Humanitas, 2001. pp. 11-15

LANDOWSKI, E. (dir.) Semiótique de passions. Bulletin, no 7, 1979.

. Passions sans nom. Paris: PUF, 2004.

. Para uma semiótica sensível. Educação e realidade. Vol. 30, n 2, 2005. Disponível em: http://seer.ufrgs.br/educacaoerealidade/article/view/12417 Consultado em: 20/12/2012

. Les interactions risquées. Nouveaux Actes Sémitiques, nº 101-103, Limoges, Pulim, 2006.

LOBAT0, M. Prefácios e entrevistas. Vol. 13, São Paulo: Brasiliense, 1951.

. Negrinha. In: MORICONI, I. (org.) Os cem melhores contos brasileiros do século. Rio de Janeiro: Objetiva, 2009, p. 78-84.

LOPES, I. C. A noção de "Profundidade" na semiótica. Revista CASA. Vol. 4, nº 2, 2006. Disponível em: http://seer.fclar.unesp.br/casa/article/view/564/485 Consultado em: 23/07/2013 
MANCINI, R. C. Dinamização nos níveis do percurso gerativo: canção e literatura contemporânea. Tese de Doutorado do programa de pós-graduação em Semiótica e Linguística geral, FFLCH/USP, 2006, 191 páginas.

MARINHO, M. C. N. A imagem da linguagem na obra de Graciliano Ramos: uma análise da heterogeneidade discursiva nos romances Angústia e Vidas Secas. São Paulo: Humanitas, 2000.

MARSCIANI, F. Note de lecture. Actes sémiotiques. Documents. IV, no 37, 1982.

Les parcours passionnels de l'indifférence. Actes sémiotiques. Documents VI, no $53,1984$.

MATHIEU-CASTELLANI, G. La rhétorique des passions. Paris: PUF, 2000.

MEYER, M. Prefácio. In: ARISTÓTELES. Retórica das paixões. Trad. Isis Borges B. Da Fonseca. São Paulo: Martins Fontes, 2000, p. xvii-li.

NIETZCHE, F. A gaia ciência. Trad. Márcio Pugliesi, Edson Bibi, Norberto de Paula Lima. Curitiba: Hemus, 2002 [1882]. [1888].

. O Anticristo. Trad. Renato Zwick. São Paulo: L\&PM (Coleção Pocket), 2008

OLIVEIRA, A. C. A estesia como condição do estético. In: .; LANDOWSKI, E. (eds.) Do inteligível ao sensível. Em torno da obra de A. J. Greimas. São Paulo: EDUC, 1995 , p. 227-236.

PARRET, H. Eléments pour une typologie raisonnée des passions. Actes sémiotiques. Documents IV, no 37, 1982.

Les passions. Essais sur la mise en discours de la subjectivité. Bruxelles: Mardaga, 1986.

PORTELA, J. C. Conversations avec Jacques Fontanille. Alfa, nํ50, vol. 1, 2006, p. 159-186.

.; BEIVIDAS, W.; LOPES, I. C.; SCHWARTZMANN, M. N. (orgs.) Semiótica: identidade e diálogos. São Paulo: Cultura Acadêmica, 2012.

PROPP, V. Morfologia do conto maravilhoso. Trad. Jasna Paravich Sarhan. Rio de Janeiro: Forense Universitaria, 1984.

RAMOS, G. Baleia. In: MORICONI, I. (org.) Os cem melhores contos brasileiros do século. Rio de Janeiro: Objetiva, 2009, p. 95-99.

REIS, C.; LOPES, A. C. Dicionário de narratologia. Coimbra: Almedina, 2007. 
REIS, Z. C. Tempos futuros. In: Duarte, Eduardo de Assis. (Org.). Graciliano Revisitado. Natal: Editora Universitária, 1995, v. 35, p. 69-93.

RICOT, J. Du bon usage de la compassion. Paris: PUF, 2013.

ROSA, J. G. R. Campo Geral. In: . Manuelzão e Miguilim. Rio de Janeiro: Nova Fronteira, 1996, p. 11-142.

. Conversa de bois. In: Sagarana. Rio de Janeiro: Nova Fronteira, 2001.

ROUSSEAU, J. J. Discurso sobre a origem e os fundamentos da desigualdade entre os homens. Trad. Maria Ermantina Galvão. São Paulo: Martins Fontes, 1999 [1755].

. Emílio ou da educação. Trad. Roberto Leal Ferreira. São Paulo: Martins Fontes, 2004 [1762].

. Os devaneios do caminhante solitário. Trad. Julia da Rosa Simões. São Paulo: L\&PM (Coleção Pocket), 2008 [1776].

SCHOPENHAUER, A. Sobre o fundamento da moral. Trad. Maria Lúcia Cacciola. São Paulo: Martins Fontes, 1995 [1840].

SMITH, A. Théorie des sentiments moraux. Trad. Michaël Biziou, Claude Gautier e Jean-François Pradeau. Paris: PUF, 1999 [1759].

TATIT, L. Quantificações subjetivas: crônicas e críticas. Cadernos de Letras da UFF. Dossiê: Linguagens em diálogo, no 42, p. 35-50, 2011. Disponível em: http://www.cadernosdeletras.uff.br/images/stories/edicoes/42/artigo2.pdf Consultado em: 25/11/2012

TEIXEIRA, L. Da Imperfeição: um marco nos estudos semióticos. Galáxia, no 4, 2002, p. 257-261.

THÜRLEMANN, F. L'admiration dans l'esthétique du XVIIe siècle. Actes Sémiotiques. Documents, II, no 11, Paris, CNRS, 1980.

XISTO, P. A busca da poesia. In: COUTINHO, E. F. (org.) Guimarães Rosa. Rio de Janeiro: Civilização Brasileira (Coleção Fortuna Crítica, vol. 6), 1983, p. 113-141.

ZILBERBERG, C. Approche schématique de la rhétorique. In: BALLABRIGA, M. (dir.) Sémantique et rhétorique. Toulouse: EUS (Editions Universitaires du Sud), 1998. p.199-223.

. De l'affect à la valeur. In: CASTELLANA, M. (org.) Texte et valeur. Paris: l'Harmattan, 2001a, p. 43-78. 
Forme, fonction affect. In: Louis Hjelmslev a cent'anni dalla nascita. Padoue: Imprimitur, 2001b, p. 79-100.

Razão e poética do sentido. Trad. Ivã Carlos Lopes, Luiz Tatit e Waldir Beividas. São Paulo: EDUSP, 2006.

Louvando o acontecimento. Galáxia, vol. 7, no 13, jun. 2007, p. 13-28. Disponível em: http://revistas.pucsp.br/index.php/galaxia/article/view/1472 Consultado em: 17/06/2013

Elementos de semiótica tensiva. Trad. Ivã Carlos Lopes, Luiz Tatit e Waldir Beividas. São Paulo: Ateliê Editorial, 2011.

. La structure tensive. Liège: Presse Universitaire de Liège, 2012. 


\section{ANEXos}

Resumo dos contos 
Anexo 1: Resumo parafrástico de "Conversa de bois", de Guimarães Rosa, referente aos momentos de sofrimento de Tiãozinho, retratado no causo contado por Manuel Timborna ao narrador do conto.

O causo começa com a aparição de um carro-de-bois "na encruzilhada da Ibiúva, logo após a cava do Mato-Quatro" (ROSA, 2001, p. 326), puxado por oito bois e conduzido pelo menino guia de nome Tiãozinho, que, à frente de todos, vinha triste. Atrás, equilibrado sobre o carro, vinha Agenor Soronho, o carreiro, "homenzão ruivo, de mãos sardentas, muito mal-encarado" (p. 328). Na carga, depositado sobre fardos de rapadura, o "esquife tosco, entre padiola e escada, com as barras atadas com embira e cipó” (p. 344), contendo o cadáver do pai de Tiãozinho, falecido naquela manhã após longa enfermidade. Durante o trajeto, os bois vão conversando e contando causos, enquanto o garoto sofre com o calor, o cansaço, os maus-tratos recebidos do carreiro Agenor e com a morte do pai. Sua tristeza o faz pensar no que passou... Na doença e no sofrimento vivido por seu pai, nos seus próprios sentimentos diante essas circunstâncias, no rancor que sentia pela mãe dada a confiança e intimidade devotadas ao carreiro, bem como no ódio que ele tinha por este último. 0 pequeno guia se vê revoltado com o adultério da mãe e ultrajado pela crueldade do carreiro, compadecendo-se, ao mesmo tempo, das penas do pai. "Pobre do pai!... Tiãozinho tinha de levar a cuia com feijão, para comer junto com ele, porque nem que a mãe não tinha paciência de pôr comida na boca do paralítico... E ela, com seu Soronho, tinham, para comer, outras coisas, melhores...” (p. 339). Ao longo do percurso, o calor e o cansaço aumentam, o menino rememora suas últimas horas com o pai, a morte naquela manhã, o choro da mãe e a mobilização dos vizinhos... "Não quer pensar mais no pai em-antes. Mas não tem ideia para poder deixar de pensar... 0 pai gemendo... Rezando com ele... E se rezasse também agora?... Devia..." (p. 345). 0 carreiro, durante todo o trajeto até a vila, não para de hostilizar e atormentar Tiãozinho, que em meio a sua dor e revolta "cresce de ódio", alimentando pensamentos de vingança e imaginando a morte de Agenor Soronho - "Mas Tiãozinho espera... Há-de chegar o dia!... Quando crescer, quando ficar homem, vai ensinar ao seu Agenor Soronho... Ah, isso vai!... Há 
de tirar desforra boa, que Deus é grande!..." (p. 341). Já mais próximos do cemitério do arraial, os bois começam a falar sobre o penar de Tiãozinho, que juntamente com o carreiro seguem agora cochilando. "- 0 bezerro-de-homem está andando mais devagar ainda. Ele também está dormindo. Dorme, caminhando como nós sabemos fazer. Daqui a pouco ele vai deixar cair o seu pau-comprido, que nem um pedaço quebrado de canga... Já babou muita água dos olhos... Muita..." (p. 357). De repente, uma estranha associação entre o pensar dos bois e o de Tiãozinho se instaura e o desejo de vingança do garoto se transforma na ação dos bois, resultando, de fato, na morte de Soronho. 
Anexo 2: Resumo parafrástico da passagem de "Campo Geral”, de Guimarães Rosa, referente ao momento da morte de Dito, irmão da personagem central, Miguilim.

Tudo começa quando, em uma manhã, ao nascer do sol, Dito resolve ir à subida para a Laje da Ventação espiar uma coruja em seu ninho. Miguilim não gosta da ideia, repetindo várias vezes que Dito não deveria ter ido. Já em casa, o menino corre com os irmãos e toda a família atrás do mico-estrela, que havia fugido, causando a maior confusão. Na perseguição, ele pisa em um caco de pote, machucando profundamente o pé - "um talho enorme, descia de um lado, cortava por baixo, subia da outra banda" (ROSA, 1996, p. 101). Quando parecia já se recuperar do ferimento, Dito é acometido por uma forte dor nas costas e na cabeça. A família toda se mobiliza na tentativa de lhe aliviar o sofrimento, mas ele só fazia gemer e gritar. Miguilim, sempre muito apegado ao irmão, fica a seu lado, tentando animá-lo com a montagem do presépio e com as histórias que Dito tanto gostava de ouvir - "mesmo quando o Dito tinha sono, o Dito agora queria dormir quase todo tempo" (p. 103). Com o passar dos dias, a dor-de-cabeça intensa volta e ele começa a ter febre alta. Ele piora, tendo agora "as pernas duras, dobradas nos joelhos, a cabeça dura na nuca, só para cima ele olhava" (p. 105), dado a infecção do corte, que aumentava a olhos vistos. No desespero de amenizar a agonia do irmão, alegrando-o de alguma forma, Miguilim pede a Rosa, empregada da casa, que ensine o papagaio, Papaco-o-Paco, a pronunciar o nome de Dito. Por esses dias, o menino piora muito, deixando todos sem esperança de melhora. Já tomado pela fraqueza do corpo, ele pede para ver Miguilim, queria ficar sozinho com o irmão para se despedir e consolá-lo. “Miguilim, Miguilim, vou ensinar o que agorinha eu sei, demais: é que a gente pode ficar sempre alegre, alegre mesmo com toda coisa ruim que acontece acontecendo. A gente deve de poder ficar então mais alegre, mais alegre por dentro!..." (p. 108). Desesperado, aos gritos, Miguilim é retirado do quarto, fugindo para o quintal, onde encontra Mãitina, outra empregada da casa que, conforme acreditavam, era uma feiticeira. Soluçando, Miguilim pede a ela que faça todos os feitiços que souber para salvar a vida de Dito, até que, de repente, "adivinhou que era tarde, que nada mais adiantava" (p. 108). Ele volta para casa, 
corre para o quarto e, chorando muito, assiste à mãe lavando o corpo morto do irmão - "o carinho da mão de mãe segurando aquele pezinho do Dito era a coisa mais forte neste mundo" (p. 109). Muitas pessoas vêm para o enterro e Miguilim fica orgulhoso "de que tanta gente ali estivesse, todos por causa do Dito, para honrar o Dito" (p. 110). Os dias que seguem são muito difíceis para Miguilim, que não conseguia parar de chorar e de sentir a falta do irmão. 0 sofrimento parece não passar nunca e o coração dele começa a se endurecer. Mãitina tem, então, uma ideia para ajudá-lo a enfrentar a dor: juntou roupas, brinquedos e alguns outros guardados do Dito e enterrou tudo no quintal, marcando o lugar com pedrinhas lavadas do riacho - "Era mesma coisa se o Dito estivesse depositado ali, e não no cemiteriozinho longe, no Terentém" (p. 114). Para tirá-lo da tristeza, começam a colocá-lo para trabalhar: debulhar milho, capinar a horta, buscar cavalo no pasto etc. Mas o pensamento está sempre em Dito. Outras situações acontecem e vão, todas, endurecendo, cada vez mais, o coração de Miguilim, que deixa o mundo inocente das crianças para trilhar a dura realidade do mundo adulto. 
Anexo 3: Resumo parafrástico do conto "Negrinha”, de Monteiro Lobato.

Negrinha era uma pobre órfã de sete anos, filha de escrava, e de olhos assustados. Era criada por dona Inácia, viúva e sem filhos, aristocrata, dona de uma fazenda, inconformada com a abolição da escravatura e por isso conservava a menina para extravasar a sua crueldade, aplicando na pequena, ela e os outros criados, os mais severos maus tratos, tanto verbais (xingamentos, ordens duras e palavras rudes) quanto físicos (beliscões, tapas e "crocres", etc). "A mesma coisa, o mesmo ato, a mesma palavra provocava ora risadas, ora castigos." (LOBATO, 2009, p. 79). Dona Inácia, que os padres viam como "uma virtuosa senhora, dama de grandes virtudes apostólicas, esteio da religião e da moral" (p. 78), descarregava sua amargura na menina, e deleitava-se com isso a ponto de seu rosto ganhar um brilho especial só em imaginar a aplicação de um castigo mais elaborado. Um dia, por uma ingênua malcriação feita a uma criada nova que furtara do prato de Negrinha "um pedacinho de carne que ela vinha guardando para o fim" (p. 80), a caridosa senhora planejou algo de diabólico, "gozando-se na prelibação da tortura" (p. 80), e puniu a pobre menina enfiando-lhe um ovo fumegante na boca. Certo dia, no entanto, quando dona Inácia recebe em sua fazenda duas sobrinhas, "pequenotas, lindas meninas louras, ricas, nascidas e criadas em ninho de plumas" (p. 81), para uma temporada de férias, ocorre uma reviravolta no cotidiano de Negrinha. As meninas, com suas vestes elegantes eram alegres e agitadas e Negrinha teve a certeza de que seriam castigadas pelas balbúrdias, assim como ela era castigada por qualquer movimento ou barulho. Mas, para a sua surpresa, não houve castigo, ficando clara a diferença que existia entre ela e aquelas meninas, e "a dura lição da desigualdade humana lhe chicoteou a alma” (p. 81). As sobrinhas, ao perceberem a ingênuidade de Negrinha e seu êxtase ao contemplar os seus brinquedos, e em especial a boneca de louça que a seus olhos parecia um anjo, oferecem-lhe a boneca, divertindo-se com tamanha admiração. “- Pegue! Negrinha olhou para os lados, ressabiada, com o coração aos pinotes. Que ventura, santo Deus! Seria possível? Depois pegou a boneca. E muito sem jeito, como quem pega o Senhor menino, sorria para ela e para as meninas, com assustados relanços de 
olhos para a porta. Fora de si, literalmente..." (p. 82) Foi por isso que não viu dona Inácia entrar, sendo tomada por grande pavor ao se dar conta da presença da senhora na sala, "passando-lhe num relance pela cabeça a imagem do ovo quente e hipóteses de castigos ainda piores" (p. 82). Mas diante aquela alegria tão irradiante e tão bonita de se ver "o seu duro coração afinal bambeou. E pela primeira vez na vida foi mulher. Apiedou-se." (p. 82) A cruel senhora permite, então, que Negrinha vá brincar com as meninas. Ao final das férias, dona Inácia, mais serena, já não castigava a criança. Algo se transformara também para a pequena órfã. "Negrinha, coisa humana, percebeu nesse dia da boneca que tinha uma alma. Divina eclosão!" (p. 83). E depois da partida das meninas, ciente de sua condição humana, mas de sua vida de coisa, é tomada por infinita tristeza e melancolia, definhando em seu canto até morrer, esquecida por todos. Foi enterrada em uma vala comum e dela "ficaram no mundo apenas duas impressões. Um cômica, na memória das meninas ricas. [...] Outra de saudade, no nó dos dedos de dona Inácia” (p. 84). 
Anexo 4: Resumo parafrástico do conto "Baleia”, de Graciliano Ramos.

"A CACHORRA Baleia estava para morrer. Tinha emagrecido, o pêlo caíra-lhe em vários pontos, as costelas avultavam num fundo róseo, onde manchas escuras supuravam e sangravam, cobertas de moscas" (RAMOS, 2009, p. 95). Fabiano, ao ver que nada mais se podia fazer e querendo lhe aliviar o sofrimento, resolveu matá-la, para desespero dos meninos e tristeza de Sinhá Vitória, que tinham a cachorra "como uma pessoa da família" (p. 95). Tendo, cautelosamente, preparado a arma, o que aumentava a angústia dos meninos e de Sinhá Vitória, fechados na camarinha até a consumação do fato, Fabiano sai em busca de Baleia. A cachorra, ao pressentir o disfórico porvir, estampado nas feições de seu dono, tenta fugir, escondendo-se atrás de uma árvore. Mas a manobra de nada adianta e "a carga alcançou os quartos de Baleia, que se pôs a latir desesperadamente" (p. 96). Cheia de dor e meio desorientada, a cachorra foge sem destino, aos pulos. "Defronte ao carro de bois faltou-lhe a perna traseira. E, perdendo muito sangue, andou como gente em dois pés, arrastando com dificuldade a parte posterior do corpo" (p. 97). Cada vez mais fraca, com dor e sem conseguir entender direito o que lhe acontecia, teve vontade de morder Fabiano, "que lhe apareceu diante dos olhos vidrados, com um objeto esquisito na mão. Não conhecia o objeto, mas pôs-se a tremer, convencida de que ele encerrava surpresas desagradáveis" (p. 97-98). Deu-se conta de que não podia mordê-lo, "tinha nascido perto dele, numa camarinha, sob a cama de varas, e consumira a existência em submissão" (p. 98); do seu lado, Fabiano, constatando a situação, afasta-se. Baleia começa, então, a lembrar de seus deveres e obrigações, e "uma angústia apertou-lhe o pequeno coração. Precisava vigiar as cabras" (p. 98). Cada vez mas distante da realidade e da consciência de sua atual situação, a morte se aproxima da cachorra e com ela as lembranças de tempo felizes, entremeadas pela dor crescente. "Baleia queria dormir. Acordaria feliz, num mundo cheio de preás. E lamberia as mãos de Fabiano, um Fabiano enorme. As crianças se espojariam com ela, rolariam com ela num pátio enorme, num chiqueiro enorme. 0 mundo ficaria todo cheio de preás, gordos, enormes" (p. 99). 